\title{
BASELINE RISK AsSESSMENT of Ground Water Contamination at the URanium Mill Tailings Site Near Salt lake City, Utah
}

September 1995

\section{DISCLAIMER}

This report was prepared as an account of work sponsored by an agency of the United States Government. Neither the United States Government nor any agency thereof, nor any of their employees, makes any warranty, express or implied, or assumes any legal liability or responsibility for the accuracy, completeness, or usefuiness of any information, apparatus, product, or process disclosed, or represents that its use would not infringe privately owned rights. Reference herein to any specific commercial product, process, or service by trade name, trademark, manufacturer, or otherwise does not necessarily constitute or imply its endorsement, recommendation, or favoring by the United States Government or any agency thereof. The views and opinions of authors expressed herein do not necessarily state or reflect those of the United States Government or any agency thereof. 


\section{NOT INTENDED FOR PUBLIC RELEASE}

This report has been reproduced from the best available copy.

Number of pages in this report: 171

For availability contact:

Office of Scientific and Technical Information

P.O. Box 62

Oak Ridge, TN 37831

(615) 576-8401 


\section{DISCLAIMER}

Portions of this document may be illegible in electronic image products. Images are produced from the best available original document. 
REV. 1

\author{
BASELINE RISK ASSESSMENT \\ OF GROUND WATER CONTAMINATION \\ AT THE URANIUM MILL \\ TAILINGS SITE NEAR \\ SALT LAKE CITY, UTAH
}

September 1995

Prepared for

U.S. Department of Energy UMTRA Project Office Albuquerque, New Mexico

Prepared by

Jacobs Engineering Group Inc.

Albuquerque, New Mexico 


\section{CITIZENS' SUMMARY}

\section{INTRODUCTION}

The Uranium Mill Tailings Remedial Action (UMTRA) Project consists of two phases: the first is the Surface Project, and the second is the Ground Water Project. For the UMTRA Project site known as the Vitro site, near Salt Lake City, Utah, Surface Project cleanup occurred from 1985 to 1987 . Tailings and radioactively contaminated soils and materials were taken about 85 miles (140 kilometers) west from the Vitro site to a disposal cell at Clive, Utah. The surface cleanup reduced radon and other radiation emissions and prevents further contamination of ground water.

The UMTRA Project's second phase, the Ground Water Project, evaluates the nature and extent of ground water contamination resulting from uranium processing and determines a strategy for ground water compliance with the Environmental Protection Agency (EPA) ground water standards established for the UMTRA Project. This ground water strategy must protect public health and the environment from radiological and nonradiological hazards. A risk assessment is one of the tools used to evaluate these hazards.

A risk assessment is the process of describing a source of contamination and showing how that contamination may reach people and the environment. The amount of contamination people or the environment may be exposed to is calculated and used to characterize the possible health or environmental effects that may result from this exposure.

This risk assessment report is the first site-specific document prepared for the UMTRA Ground Water Project at the Vitro site. The results of this report and further site characterization of the Vitro site will be used to determine what is necessary, if anything, to protect human health and the environment while complying with EPA standards.

\section{RISK SUMMARY}

Because no one is drinking the site-impacted water and no one is using it for irrigation or watering livestock, no human health risks are currently associated with the affected ground water. This favorable risk situation will continue if land and water use near the site do not change. Changes in land use may or may not create future risks. Therefore, any specific land uses determined for the site should be evaluated to identify potential health and environmental risks that might result from the contaminated ground water or surface water.

Because future land use at the site is not known, this risk assessment looks at the worstcase possibility. Calculations are performed on the assumption that a well placed in the area of affected ground water is used as a sole source of drinking water for people and livestock or to irrigate crops. Under this hypothetical scenario, those people and livestock could experience certain adverse health effects. Crops could also be adversely affected by the contaminated ground water. If that is so, the affected ground water from the shallow aquifer should not be used. 
This risk assessment is conservative in the sense that it evaluates the residential scenario associated with the highest level of exposure, which could result from drinking water from the most contaminated wells on the site.

\section{GROUND WATER QUALITY AND USES}

\section{Background ground water auality}

Background ground water quality is the quality of water that would exist in the Vitro site area if uranium milling had never occurred. Two aquifers are present in the vicinity of the Vitro site: a shallow aquifer at 5 to 70 feet ( 1.5 to 20 meters) below land surface and a deeper aquifer at 70 to 500 feet or more (20 to 150 meters) below land surface. The deep aquifer is a source of municipal water in the Salt Lake City area.

In the shallow aquifer, the natural ground water is not fit for human consumption without substantial treatment. Arsenic, chloride, sodium, sulfate, and high levels of total dissolved solids from sources other than the milling operations (including some natural) exist in the aquifer. The ground water in the shallow aquifer does not move into the deep watersupplying aquifer because of upward pressure between the two aquifers.

\section{Site-related ground water quality}

Chloride, fluoride, magnesium, manganese, molybdenum, radium-226, sodium, sulfate, and uranium are the main contaminants in the shallow aquifer that are associated with former uranium processing activities. The contamination appears to extend some distance off the site to the northwest; however, its full extent has not been determined. The contamination may be entering surface water in the South Vitro ditch in the area of the south boundary of the site.

\section{HUMAN HEALTH RISK ASSESSMENT}

\section{Methods}

The risk assessment starts by identifying ground water contaminants resulting from uranium ore processing. This is done by comparing water quality data from wells drilled on the site to water quality data from background wells. Once contaminants are identified, the next step is to examine possible human health problems that could result from drinking the water containing these contaminants.

Both current and possible future human health risks are evaluated. To evaluate current risks, it is necessary to determine whether anyone is currently drinking the water. To evaluate future risks, it is assumed that people are getting all their drinking water from a well drilled into the most contaminated area beneath the site. 
Health risks are evaluated for the age group most likely to experience health problems from the contamination. Noncarcinogenic risks are evaluated for children. Children (age group 1 to 10 years) are typically the most likely to be harmed from drinking contaminated ground water because children's bodies are small and they drink a lot of water. Infants (age group 0 to 1 year) generally drink less tap water than children but are nevertheless especially sensitive to contaminants like sulfate. In the case of cancer, which takes a long time to develop, risks are evaluated for adults (age group 11 years and up).

The seriousness of health effects varies for several reasons. The levels of contaminants in ground water vary from one well sampling round to the next. People vary in their body weight and consumption of water as well as in how their bodies react to chemical exposures. All these differences are considered in this risk assessment whenever possible. The risk assessment provides the reader with graphs to show different possible exposure levels along with the most current scientific information on the types of health effects that may result from the hypothetical exposure.

\section{Results}

There are no drinking water, livestock, or irrigation wells in the shallow aquifer at or near the Vitro site. Because no one uses the ground water for drinking or other purposes, it currently causes no health problems. This situation will continue if water use near the site does not change. It is unlikely that people will ever use the shallow aquifer ground water for drinking. Water from the shallow aquifer is naturally poor, and good water is available from the deep, confined aquifer and from the city.

Based on current concentrations of contaminants found in the most contaminated wells, there are possible health risks associated with drinking this ground water. Table CS-1 provides information on the nature of possible health problems that could be expected.

Note that only the people who drink all of their water from a well placed in the most contaminated portion of the aquifer (a fraction of the site) would be expected to experience the health problems described in Table CS-1. The table therefore provides the upper limit of possible risks; real risks would probably be lower.

The most important possible health hazard in this ground water is sulfate. Ingestion of sulfate in the amounts found in the ground water, particularly ingestion by infants, could cause severe diarrhea leading to dehydration in only a short time. However, sulfate in high amounts makes water taste and smell unpleasant, which discourages use. 
Table CS-1 Human health effects from hypothetical future use as drinking water of contaminated ground water from the former Vitro site

\begin{tabular}{|l|l|l|}
\hline \multirow{2}{*}{ Contaminant } & \multicolumn{1}{|c|}{$\begin{array}{c}\text { Nature of health problems possible if people were drinking water from the } \\
\text { shallow aquifer }\end{array}$} \\
\cline { 2 - 3 } & \multicolumn{1}{|c|}{ Short-term effects } & \multicolumn{1}{c|}{ Long-term effects } \\
\hline Fluoride & $\begin{array}{l}\text { None } \\
\text { System and of skeletal muscles in } \\
\text { people with kidney problems }\end{array}$ & Mild dental damage (mottling) \\
\hline Manganese & None & $\begin{array}{l}\text { Mild neurological symptoms include } \\
\text { memory loss, irritability, and muscle } \\
\text { rigidity }\end{array}$ \\
\hline Molybdenum & None & $\begin{array}{l}\text { Mild effects include copper deficiency } \\
\text { anemia }\end{array}$ \\
\hline Radium-226 & None & None \\
\hline Sodium and chloride & Unpleasant taste (salty) & Hypertension in sensitive people \\
\hline Sulfate & $\begin{array}{l}\text { Diarrhea and dehydration, } \\
\text { particularly in infants }\end{array}$ & Unknown \\
\hline Uranium & None & None \\
\hline
\end{tabular}

These effects could vary from person to person depending on the amount of water a person drinks, body weight, dietary habits, and individual sensitivities such as the preexisting kidney or heart diseases, and other factors.

EPA - U.S. Environmental Protection Agency

The contaminated ground water also contains magnesium at levels sufficient to increase the severity of sulfate-caused diarrhea. In people with kidney disease and impaired magnesium excretion, these levels of magnesium could lead to muscle weakness, sleepiness, confusion, and other symptoms of the central nervous system depression.

Other milder health problems could result from the other contaminants if people were to drink water from the most contaminated portion of the aquifer for a long time. Fluoride levels at the site could cause dental damage in children. The amount of manganese could affect the nervous system causing mental disturbances, muscle rigidity, or tremors. The levels of molybdenum could result in copper deficiency, and the sodium chloride levels could lead to high blood pressure in people sensitive to salt. These health problems could be worse in people who have kidney problems.

\section{ECOLOGICAL AND LIVESTOCK RISK ASSESSMENT}

The ecological and livestock risk assessment presented in this document is a preliminary screening level assessment that relies on limited environmental sampling and literature information. 
In the field of ecological and livestock risk assessment, many uncertainties result from limited scientific knowledge. Information is lacking on how some chemicals affect plants and animals. The impact of chemical mixtures on plants and animals is also poorly understood. Furthermore, due to limited environmental sampling at the former Vitro site, there is no information about the level of contamination in plants or animals there.

Therefore, the possible effects of the contaminants upon grazing livestock, wildlife, and agricultural crops are evaluated. This evaluation is done by comparison of the concentration of contaminants in the ground water, in surface water, and in sediment that has been affected by contaminated ground water to available guidelines from regulatory agencies and literature values. Surface water and sediment is evaluated from different areas of the South Vitro Ditch and Mill Creek. The shallow aquifer ground water is evaluated assuming plant roots take up the most contaminated ground water. This risk assessment also examines the use of this water as a sole source of drinking water for livestock, for crop irrigation, and for a ground water-fed pond stocked with fish.

\section{Livestock results}

There are currently no adverse effects to livestock and crops associated with the contaminated ground water in the shallow aquifer. Livestock are not currently grazed or watered on or around the former Vitro site, and no agricultural crops are currently irrigated with the affected ground water. In the future, if the ground water from the most contaminated portion of the aquifer under the site were the sole source of drinking water for cattle or sheep, sulfate levels would be high enough to cause diarrhea. This could preclude using this water for livestock watering.

\section{Ecological results}

If the affected ground water were used for irrigation, several constituents, such as fluoride, manganese, or molybdenum, could be present at concentrations exceeding levels protective of plants. The molybdenum concentration in the South Vitro Ditch also exceeds levels that are believed to be protective of plants. However, available data do not address the specific tolerances of plant species growing at the Vitro site.

Although silver, chloride, and iron are found in the South Vitro Ditch at concentration levels higher than those considered protective of aquatic organisms, it could not be determined with existing data whether aquatic organisms in South Vitro Ditch are sensitive to these constituent levels.

\section{CONCLUSIONS}

Ground water contamination below the Vitro site is limited to the shallow aquifer. Currently, there are no domestic wells in this aquifer on or near the site, and livestock do not graze there. Also, crops are not grown on the site. Therefore, no health risks are currently associated with site ground water. 
This risk assessment has determined that certain health problems could occur in people and livestock if the contaminated ground water were used for drinking in the future. Therefore, neither humans or livestock should drink the untreated water. In addition, ground water could also be harmful to plants with roots in the shallow ground water and to plants irrigated with the water. Also, livestock grazing should not be permitted on those grasses growing on the site or that are irrigated with shallow ground water until the possible sitespecific risks to livestock and plants are better evaluated.

The Vitro site evaluation is ongoing and will include further characterization of ground water quality, water levels, and movement. Issues related to surface water, sediment, and plants shall be addressed in future work plans. This risk assessment and future investigations will be used to determine how to deal with the contaminated ground water. If specific plans for land use at the site are ever developed, the risks should be reevaluated. Excavations into the contaminant plume, for instance, might expose contaminated ground water to surface sources, creating a new exposure risk and thus requiring reevaluation. 
TABLE OF CONTENTS

Section

Page

1.0 INTRODUCTION.......................................................................... 1

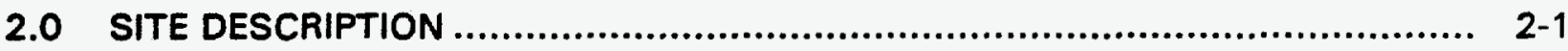

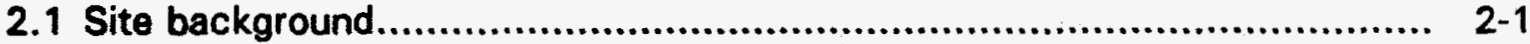

2.2 Climate ................................................................................ $2-3$

2.3 Hydrogeology ......................................................................... $2-3$

2.3.1 Shallow unconfined aquifer.............................................. $2-4$

2.3.2 Confined aquifer ............................................................. $2-8$

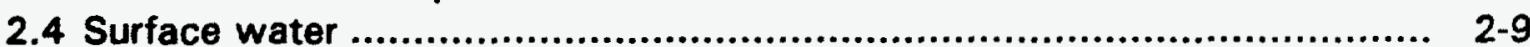

2.5 Land use ............................................................................ $2-9$

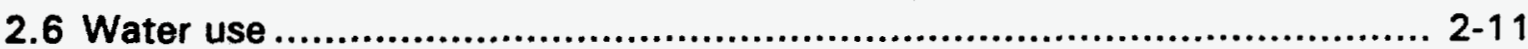

3.0 EXTENT OF CONTAMINATION .................................................... $3-1$

3.1 Background water quality summary ............................................. $3-5$

3.2 Magnitude of site-related contamination ....................................... 3-13

3.3 Statistical analysis of ground water quality .................................... 3-16

3.4 Contaminants of potential concern............................................ 3-17

3.5 Contaminant fate and transport ................................................... $3-19$

3.6 Surface water and sediment sampling ...................................... 3-22

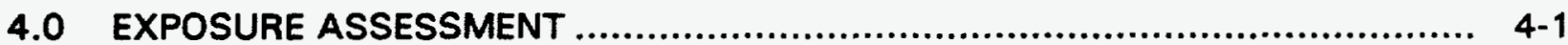

4.1 Potentially exposed population .................................................... 4-1

4.2 Exposure pathways ................................................................... 4-3

4.2.1 Drinking water ingestion................................................. 4-5

4.2.2 Dermal absorption ....................................................... 4-5

4.2.3 Ingestion of ground water-irrigated produce........................... 4-5

4.2.4 Ingestion of meat or milk from livestock drinking ground water...... 4-6

4.3 Exposure concentrations........................................................... 4-6

4.4 Estimation of intake ............................................................... 4-7

4.5 Exposure assessment uncertainties............................................ 4-19

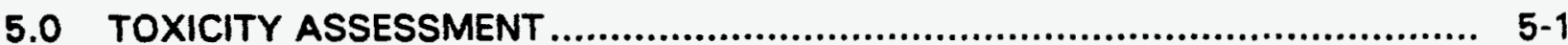

5.1 Contaminant toxicity summaries............................................... $5-1$

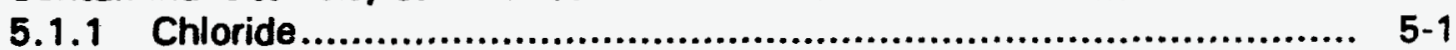

5.1 .2 Fluoride .................................................................... $5-3$

5.1.3 Magnesium .............................................................. 5-7

5.1.4 Manganese .................................................................... 5-9

5.1.5 Molybdenum .................................................................. 5-13

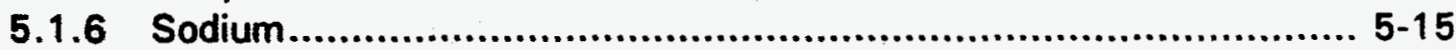

5.1 .7 Sulfate ....................................................................... 5-18

5.1 .8 Uranium ................................................................... 5-21

5.2 Contaminant interactions ......................................................... 5-25

5.3 Contaminant risk factors............................................................. 5-27 


\section{TABLE OF CONTENTS (Concluded)}

Section

Page

6.0 HUMAN HEALTH RISK EVALUATION............................................. $6-1$

6.1 Potential noncarcinogenic health effects......................................... $6-1$

6.2 Potential carcinogenic health effects ............................................ 6-11

6.3 Limits of this risk evaluation....................................................... $6-13$

7.0 ECOLOGICAL AND LIVESTOCK RISK EVALUATION .............................. $7-1$

7.1 Exposure pathways ............................................................ $7-1$

7.2 Ecological receptors .......................................................... $7-2$

7.2.1 Terrestrial resources ..................................................... 7-3

7.2.2 Aquatic resources........................................................ $7-3$

7.3 Contaminants of potential ecological concern and ecological risk ............. 7-4

7.3.1 Surface water and sediment sampling sites and results ............... $7-4$

7.3.2 Ecological risk associated with plant root transport of contaminants ............................................................... $7-9$

7.3.3 Ecological risk associated with stock ponds and irrigation water .................................................................. 7-12

7.4 Potential impacts to livestock................................................... $7-15$

7.5 Uncertainties of the ecological risk assessment.............................. $7-16$

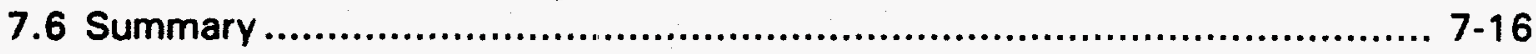

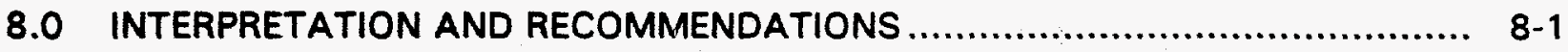

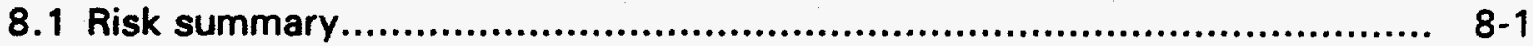

8.2 Limitations of this risk assessment ............................................. $8-2$

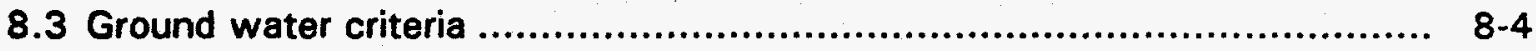

8.4 Risk mitigation measures ..................................................... $8-4$

8.5 Results of the December 1994 sampling round ............................. $8-7$

8.6 Recommendations ............................................................ 8-11

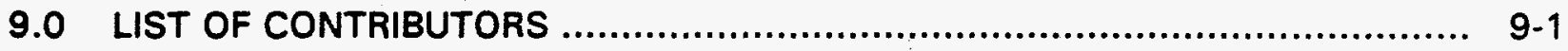

10.0 REFERENCES ............................................................................... 10 


\section{LIST OF FIGURES}

Figure

Page

2.1 Location of the South Clive disposal site and the Vitro uranium processing site, Salt Lake City, Utah, site

2.2 Monitor well, surface water, sediment, and borehole sampling locations, Salt Lake City, Utah, site .............................................................. 2-5

2.3 Geologic cross section D-D', Salt Lake City, Utah, site.............................. 2-6

2.4 Water table surface of the unconfined aquifer, Salt Lake City, Utah, site......... 2-7

2.5 Land use and location of water wells, Salt Lake City, Utah, site .................... 2-11

3.1 Approximate extent of sulfate contamination (1982-1983 data), Salt Lake City, Utah, site

3.2 Approximate extent of sulfate contamination (1992-1993 data), Salt Lake City, Utah, site

4.1 Conceptual model, Salt Lake City, Utah, site....................................... 4-2

4.2 Human exposure pathway interactions, Salt Lake City, Utah, site................. 4-4

4.3 Probability distribution of chloride concentrations, Salt Lake City, Utah, site.

4.4 Probability distribution of fluoride concentrations, Salt Lake City, Utah, site.

4.5 Probability distribution of magnesium concentrations, Salt Lake City, Utah, site.

4.6 Probability distribution of manganese concentrations, Salt Lake City, Utah, site....

4.7 Probability distribution of molybdenum concentrations, Salt Lake City, Utah, site

4.8 Probability distribution of sodium concentrations, Salt Lake City, Utah, site.

4.9 Probability distribution of sulfate concentrations, Salt Lake City, Utah, site.

4.10 Probability distribution of uranium concentrations, Salt Lake City, Utah, site

4.11 Probability distributions for tap water ingestion rates ............................. 4-17

4.12 Probability distributions for body weight ........................................ 4-18

4.13 Probability distribution of chloride intakes, Salt Lake City, Utah, site.............. 4-20

4.14 Probability distribution of fluoride intakes, Salt Lake City, Utah, site ............. 4-21

4.15 Probability distribution of magnesium intakes, Salt Lake City, Utah, site......... 4-22

4.16 Probability distribution of manganese intakes, Salt Lake City, Utah, site ......... 4-23

4.17 Probability distribution of molybdenum intakes, Salt Lake City, Utah, site........ 4-24

4.18 Probability distribution of sodium intakes, Salt Lake City, Utah, site.............. 4-25

4.19 Probability distribution of sulfate intakes, Salt Lake City, Utah, site ............... 4-26

4.20 Probability distribution of uranium intakes, Salt Lake City, Utah, site ............ 4-27

4.21 Probability distribution of uranium-234 and uranium-238 intake over a lifetime, Salt Lake City, Utah, site. 


\section{LIST OF FIGURES (Concluded)}

Figure

Page

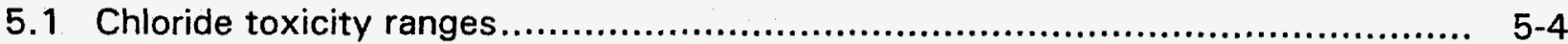

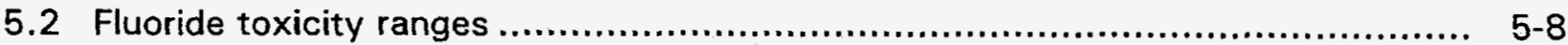

5.3 Magnesium toxicity ranges .......................................................... $5-10$

5.4 Manganese toxicity ranges .......................................................... $5-14$

5.5 Molybdenum toxicity ranges .......................................................... 5-16

5.6 Sodium toxicity ranges..................................................................... $5-19$

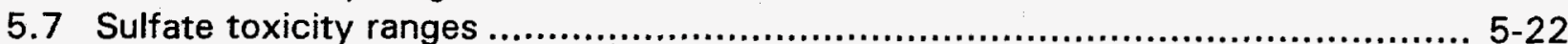

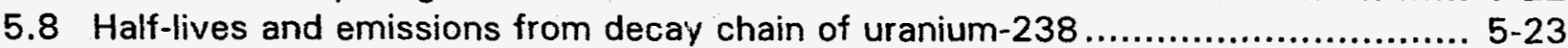

5.9 Uranium toxicity ranges .......................................................... $5-26$

6.1 Health effects of potential sulfate exposure ranges for infants, Salt Lake City, Utah, site.......................................................................... $6-2$

6.2 Health effects of potential magnesium exposure ranges for children, Salt Lake City, Utah, site.

6.3 Health effects of potential sodium exposure ranges for children, Salt Lake City, Utah, site.

6.4 Health effects of potential chloride exposure ranges for children, Salt Lake City, Utah, site.

6.5 Health effects of potential manganese exposure ranges for children, Salt Lake City, Utah, site.

6.6 Health effects of potential fluoride exposure ranges for children, Salt Lake City, Utah, site.

6.7 Health effects of potential molybdenum exposure ranges for children, Salt Lake City, Utah, site.............................................................. $6-9$

6.8 Health effects of potential uranium exposure ranges for children, Salt Lake City, Utah, site.

6.9 Increased lifetime cancer risk from uranium-234 and uranium-238 exposure ranges, Salt Lake City, Utah, site 


\section{LIST OF TABLES}

Table

Page

3.1 Monitor wells used to determine water quality in the unconfined and confined aquifers

3.2 Water quality of the confined aquifer, Salt Lake City, Utah, site

3.3 Ground water quality data, city of South Salt Lake proposed municipal water supply well, Salt Lake City, Utah, site

3.4 Comparison of background and on-site ground water quality data in the unconfined aquifer at the Salt Lake City, Utah, site, August 1990 -

February 1994, filtered water samples

3.5 Contaminants of potential concern, Salt Lake City, Utah, site

3.6 Predominant ionic species of the constituents of potential concern

3.7 Surface water quality data of Mill Creek and Jordan River, Salt Lake

City, Utah, site.

3.8 Summary of Mill Creek and Jordan River sediment chemistry data,

December 1993, Salt Lake City, Utah, site

3.9 Summary of Vitro Ditch and South Vitro Ditch sediment chemistry data, December 1993, Salt Lake City, Utah, site

5.1 Toxicity values: potential noncarcinogenic effects.................................. 5-28

5.2 Toxicity values: carcinogenic effects

6.1 Carcinogenic risk for ground water consumption pathway,

Salt Lake City, Utah, site

7.1 Constituents measured in unfiltered surface water in 1993 in

Mill Creek, Salt Lake City, Utah, site

7.2 Constituents measured in 1993 in the sediment in Mill Creek,

Salt Lake City, Utah, site

7.3 Constituents measured in 1993 in the sediment in South Vitro Ditch,

Salt Lake City, Utah, site

7.4 Constituents detected in the sediments of the shallow unconfined aquifer at the Salt Lake City, Utah, site

7.5 Comparison of deep soil concentration of contaminants of potential concern to screening benchmarks for terrestrial plants.

7.6 Comparison of contaminant levels in the unconfined shallow aquifer to screening benchmarks for terrestrial plants

7.7 Comparison of contaminant concentrations in the shallow unconfined aquifer to water quality criteria, Salt Lake City, Utah, site 


\section{LIST OF TABLES (Concluded)}

Table

Page

8.1 Concentration limits of constituents

8.2 Summary of December 1994 ground water quality data, filtered samples (unless otherwise specified), unconfined aquifer,

Salt Lake City, Utah, site

8.3 Summary of Mill Creek surface water quality data, December 1994, Salt Lake City, Utah, site

8.4 Summary of Vitro Ditch and South Vitro Ditch surface water quality data, December 1994, Salt Lake City, Utah, site 


\section{LIST OF ACRONYMS}

\section{Acronym Definition}

$\begin{array}{ll}\text { AEC } & \text { U.S. Atomic Energy Commission } \\ \text { CVWRF } & \text { Central Valley Water Reclamation Facility } \\ \text { DDPA } & \text { monododecyl phosphoric acid } \\ \text { DHHS } & \text { Department of Health and Human Services } \\ \text { DOE } & \text { U.S. Department of Energy } \\ \text { EPA } & \text { U.S. Environmental Protection Agency } \\ \text { ESADDI } & \text { estimated safe and adequate daily dietary intake } \\ \text { HEAST } & \text { Health Effects Assessment Summary Tables } \\ \text { IRIS } & \text { Integrated Risk Information System } \\ \text { LOAEL } & \text { lowest observed adverse effect level } \\ \text { MCL } & \text { maximum concentration limit } \\ \text { NOAEL } & \text { no observed adverse effect level } \\ \text { NRC } & \text { U.S. Nuclear Regulatory Commission } \\ \text { ppm } & \text { parts per million } \\ \text { RDA } & \text { recommended daily allowance } \\ \text { RfD } & \text { reference dose } \\ \text { SF } & \text { slope factor } \\ \text { TDS } & \text { total dissolved solids } \\ \text { UMTRA } & \text { Uranium Mill Tailings Remedial Action } \\ \text { UMTRCA } & \text { Uranium Mill Tailings Radiation Control Act }\end{array}$




\subsection{INTRODUCTION}

The purpose of this baseline risk assessment is to determine whether ground water contamination at the Salt Lake City, Utah, uranium processing site (known as the Vitro site) could adversely affect human health or the environment. The Salt Lake City site is one of 24 abandoned uranium mill tailings sites undergoing remediation in accordance with the requirements of the Uranium Mill Tailings Radiation Control Act (UMTRCA) of 1978 (42 USC $\$ 7901$ et seq.) under the oversight of the U.S. Department of Energy (DOE) Uranium Mill Tailings Remedial Action (UMTRA) Project. The remediation of surface contamination at the Salt Lake City uranium processing site was completed in 1987 with stabilization of the tailings and other contaminated materials and soils at Clive, Utah.

This risk assessment is a baseline assessment in the sense that it describes current ground water conditions at the site; ground water contamination was only partially characterized. This document evaluates the potential for public health and environmental risks that may need attention before the site is fully characterized. This risk assessment is based on available ground water data from wells at the processing site. Major exposure pathways have been identified and examined for this risk assessment.

This risk assessment follows the basic framework outlined by the U.S. Environmental Protection Agency (EPA) (EPA, 1989a) for evaluating hazardous waste sites to assess potential health and environmental impacts. The risk assessment framework consists of the following steps:

- Data evaluation.

- Existing data from various site investigations are combined.

- Sample results are compared to background and tailings source data.

- Appropriate chemical data are selected for the risk assessment.

- Exposure assessment.

- Exposure setting is characterized.

- Exposure pathways are identified.

- Exposure is quantified.

- Toxicity assessment.

- Toxicity values are identified

- Noncarcinogenic effects are evaluated.

- Carcinogenic effects are evaluated for radionuclides and chemical carcinogens.

- Public health risk characterization.

- Toxicity ranges are compared to predicted exposure ranges.

- Risks are combined across exposure pathways and multiple contaminants.

- Uncertainties are characterized. 
- Environmental risk.

- Potential biota exposure pathways are characterized.

- Potential ecological receptors are identified.

- Environmental risk is evaluated qualitatively.

This framework is incorporated in the methodology developed to evaluate current human health risk at UMTRA Project sites and to estimate risks from possible future use of contaminated ground water or surface water near the Vitro site (DOE, 1994a).

This risk assessment will support decisions made for the UMTRA Ground Water Project. The DOE was authorized to conduct ground water remediation under the 1988 UMTRCA Amendments Act (42 USC $\$ 7922$ et sec.) and will determine site-specific ground water compliance strategies for each site. This baseline risk assessment provides information to assist in determining the site-specific ground water compliance strategy for the Vitro site. 


\subsection{SITE DESCRIPTION}

The Salt Lake City site (the Vitro processing site) is in a large basin drained by the Jordan River. The site is between the Wasatch Mountains to the east and the Oquirrh Mountains to the west, 4 miles (mi) (6 kilometers [km]) south-southwest of the center of Salt Lake City, in the city of South Salt Lake. Figure 2.1 shows the site location.

\section{$2.1 \quad$ SITE BACKGROUND}

In 1941, a large smelting operation known as Calunite Smelter, Inc., was completed at 3300 South Street and 900 West Street in Salt Lake City. In 1946, the plant became known as the Vitro Chemical Company Calunite Plant. From 1941 through 1951, this smelter processed aluminum from aluminite. In May 1951, the Vitro plant began processing uranium ore under contract with the U.S. Atomic Energy Commission (AEC). Because the plant operator was the Vitro Chemical Company, the site is often referred to as the Vitro processing site.

From 1951 to 1964, the Vitro plant processed uranium ores by acid leaching. In 1965 , the mill converted to the production of vanadium. Vanadium production ceased in 1968 and the plant was dismantled in 1970.

In 1951, Vitro Chemical Company began processing uranium ores using the phosphate precipitation technique. Uranium ore was first roasted and then leached in a sulfuric acid solution. Metallic aluminum was added to the solution as a reducing agent and the $\mathrm{pH}$ was kept in the range of 1.0 to 1.8 to promote uranium precipitation (in a reduced trivalent form) as a phosphate. After the solids (tails) were separated from the uranium-bearing leachate, the uranium was precipitated from the acid solution by adding orthophosphate. The uranium phosphate precipitate was then digested in a 10- to 30-percent sodium or potassium hydroxide solution to remove excess phosphate. The mill could process 100 tons of ore per day in 1951 and by 1956 was processing 500 tons per day (Merritt, 1971).

In 1957, the plant was converted to a solvent extraction processing circuit; 600 tons of ore per day were processed with this method. After the ore was roasted and leached in a sulfuric acid solution adjusted to a $\mathrm{pH}$ of 1 , a reducing agent (typically sodium hydrosulfide) was added to the slurry to reduce ferric iron and molybdenum. The solids were separated from the solution, then disposed of in tailings piles, and the solution was mixed with an organic solution. This organic solution was 10 percent or less monododecyl phosphoric acid (DDPA) dissolved in kerosene. While the kerosene solution and acid-aqueous solution were immiscible, intensive agitation allowed the uranium in the acid solution to complex with the DDPA in the kerosene solution, thus removing the uranium from the acid solution. The spent acid solution, called raffinate, 

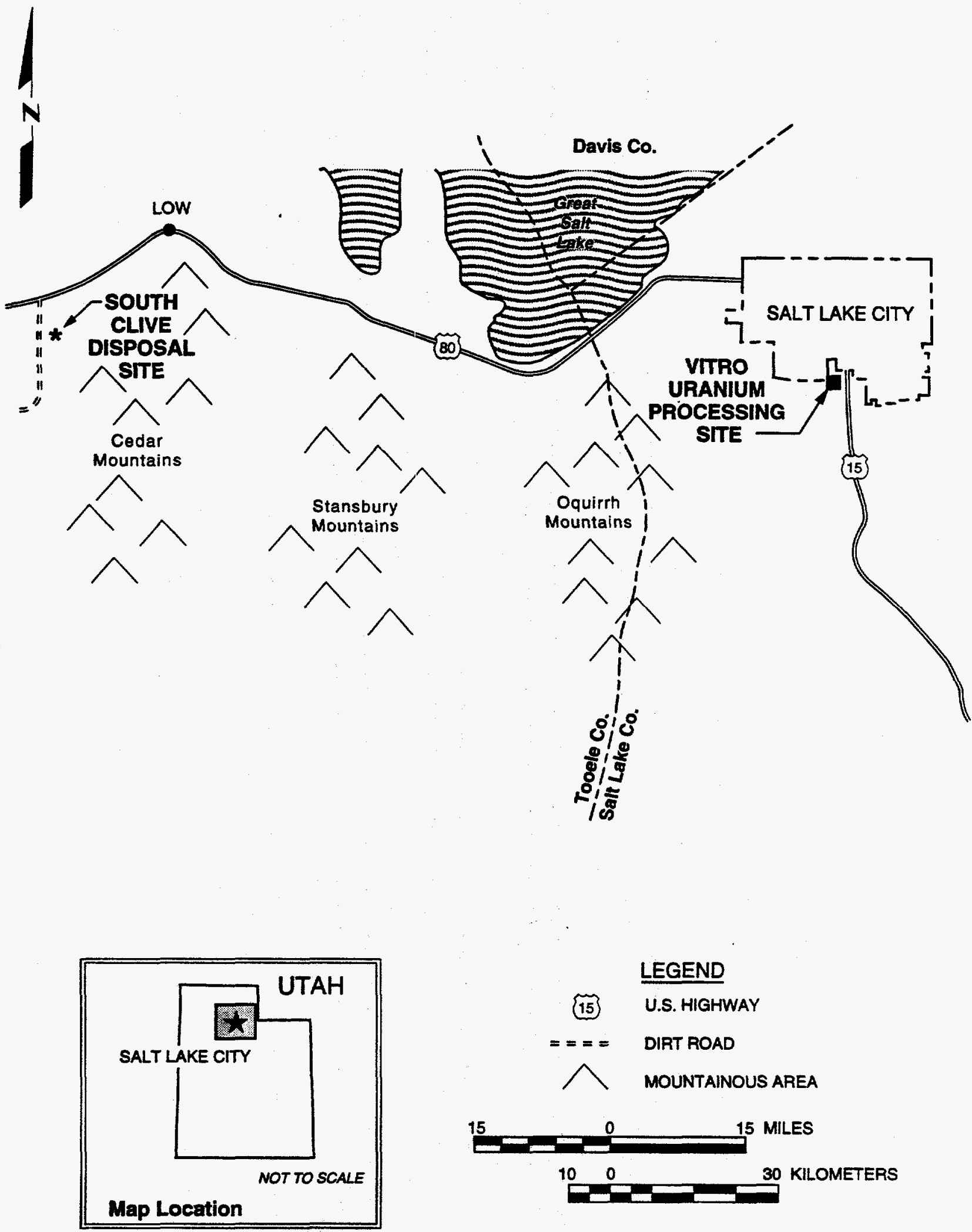

FIGURE 2.1

LOCATION OF THE SOUTH CLIVE DISPOSAL SITE AND

THE VITRO URANIUM PROCESSING SITE SALT LAKE CITY, UTAH, SITE 
was pumped to evaporation ponds. This raffinate may have contained up to 5 parts per million (ppm) DDPA (Merritt, 1971).

The uranium was extracted from the kerosene solution by mixing the organic liquid with aqueous 10 normal hydrochloric acid. The uranium complexed with chloride in the aqueous solution, which was then separated from the immiscible kerosene. The hydrochloric acid solution was evaporated, and the distilled acid was recovered for reuse. After uranium-bearing solids left by evaporation of the acid were diluted with water, ammonia was added to precipitate ammonium diuranate, which was heated to drive off excess ammonia. This process resulted in a final product of uranium oxide $\left(\mathrm{U}_{3} \mathrm{O}_{8}\right)$.

The DDPA-kerosene solution was recycled. However, buildup of thorium, titanium, and scandium in the solvent required periodic treatment to remove these elements from the kerosene solution. This was done by stripping with 10 percent hydrofluoric acid solution, which resulted in precipitation of thorium, titanium, and scandium as fluorides. These precipitates were shipped elsewhere for refining (Merritt, 1971).

Remedial action at the Salt Lake City uranium processing site occurred from January 1985 to March 1987. A total of 2,798,000 cubic yards (yd ${ }^{3}$ ) $\left(2,139,000\right.$ cubic meters $\left.\left[\mathrm{m}^{3}\right]\right)$ of tailings were removed from the site and stabilized in a disposal cell at Clive, Utah (approximately $85 \mathrm{mi}[140 \mathrm{~km}$ ] west of Salt Lake City). The state of Utah was the remedial action contractor. The surface cleanup left the former Vitro site free of process-related soil contamination (except for the areas where supplemental standards for radium226 and thorium-230 were applied to parts of the site) (DOE, 1995b). Clean fill was placed in all excavated areas and the ground was recontoured and revegetated.

\subsection{CLIMATE}

The Salt Lake City site is in the intermountain plateau climatic zone that extends between the Cascade and Sierra Nevada ranges and the Rocky Mountains. This area is classified as a middle-latitude, dry climate or steppe, characterized by a hot, dry summer, cool spring and fall, and moderately cold winter. Normal daily highs range from about 37 degrees Fahrenheit $\left({ }^{\circ} \mathrm{F}\right)\left(3\right.$ degrees Celsius $\left.\left[{ }^{\circ} \mathrm{C}\right]\right)$ in January to $93^{\circ} \mathrm{F}\left(34^{\circ} \mathrm{C}\right)$ in July, while normal daily lows range from about $19^{\circ} \mathrm{F}\left(-7^{\circ} \mathrm{C}\right)$ in January to $61^{\circ} \mathrm{F}\left(16^{\circ} \mathrm{C}\right)$ in July (DOE, 1984a).

The prevailing winds are from the southeast and south-southeast. Average annual precipitation from 1948 to 1983 was 15.8 inches.

\subsection{HYDROGEOLOGY}

The lithology underlying the Salt Lake City site consists of a thick sequence of Quaternary lacustrine-fluvial deposits with minor alluvial overburden.

Unconsolidated lacustrine deposits below the site are approximately 700 feet $(\mathrm{ft}$ ) 
(210 meters [m]) thick (Arnow et al., 1970). Tertiary deposits underlie the Quaternary deposits to a depth of approximately $1200 \mathrm{ft}(370 \mathrm{~m})$ (Mattick, 1970). These Tertiary deposits consist of semiconsolidated clay, sand, and gravel interspersed with lava and cemented layers of sand and gravel (Arnow et al., 1970). After site surface remediation, the upper 4 to $13 \mathrm{ft}(1.2$ to $3.9 \mathrm{~m})$ of soil was replaced with clean sandy gravel fill material.

Borehole samples from previous investigations (Figure 2.2) indicate the shallow materials consist of unconsolidated silt, clayey-silt, silty-clay, and lenticular sands deposited in a fluvial-lacustrine environment. These sediments are complexly interbedded, and correlation between individual boreholes is sometimes difficult. Figure 2.3 shows a geologic cross section of the site. Borehole data suggest siltier and more clayey sediments are to be found in the southern and eastern portions of the site (monitor wells 130 to 133) and sandier sediments occur in the northern and western portions of the site (monitor wells 134 and 135). Monitor well locations are shown in Figure 2.2.

The ground water regime in the vicinity of the Salt Lake City site is generally characterized by two aquifer systems: a shallow, unconfined system and a deeper, confined system. The two aquifers are separated by interbedded layers of low-permeability clays and silts. Wells at depths from 70 to $330 \mathrm{ft}(20$ to $100 \mathrm{~m}$ ) below the ground surface are under substantial artesian pressure, with ground water flowing from several wells. Therefore, the potential for vertical ground water flow is upwards from the confined into the unconfined aquifer. Near the site, lateral ground water flow in both aquifers is predominantly to the west-northwest, toward the Great Salt Lake.

\subsubsection{Shallow unconfined aquifer}

In the vicinity of the former tailings pile, the upper, unconfined aquifer is approximately $45 \mathrm{ft}(14 \mathrm{~m})$ thick. Ground water yields from the interbedded strata of this aquifer system depend on the lithology of the screening location. Results from DOE on-site aquifer pumping tests conducted in July 1992 indicate ground water yields can range from much less than 1 gallon (4 liters) per minute from the silts and clays, to long-term sustained yields of more than 4 gallons (16 liters) per minute from the fine-grained sands and silty sands.

The major sources of recharge to the unconfined aquifer are precipitation infiltration and upward leakage from the confined aquifer. Ground water in the unconfined aquifer generally discharges to surface water drainages such as Mill Creek and the Jordan River (Figure 2.2). However, a highway drain below the Denver \& Rio Grande Western Railroad overpass at 3300 South Street locally influences ground water flow in the unconfined aquifer. Ground water entering the drain is pumped out of a sump into a culvert that discharges into the head of South Vitro Ditch. Ground water levels in the area indicate a local ground water divide in the southeast corner of the site draws ground water from that area toward the drain (Figure 2.4). 


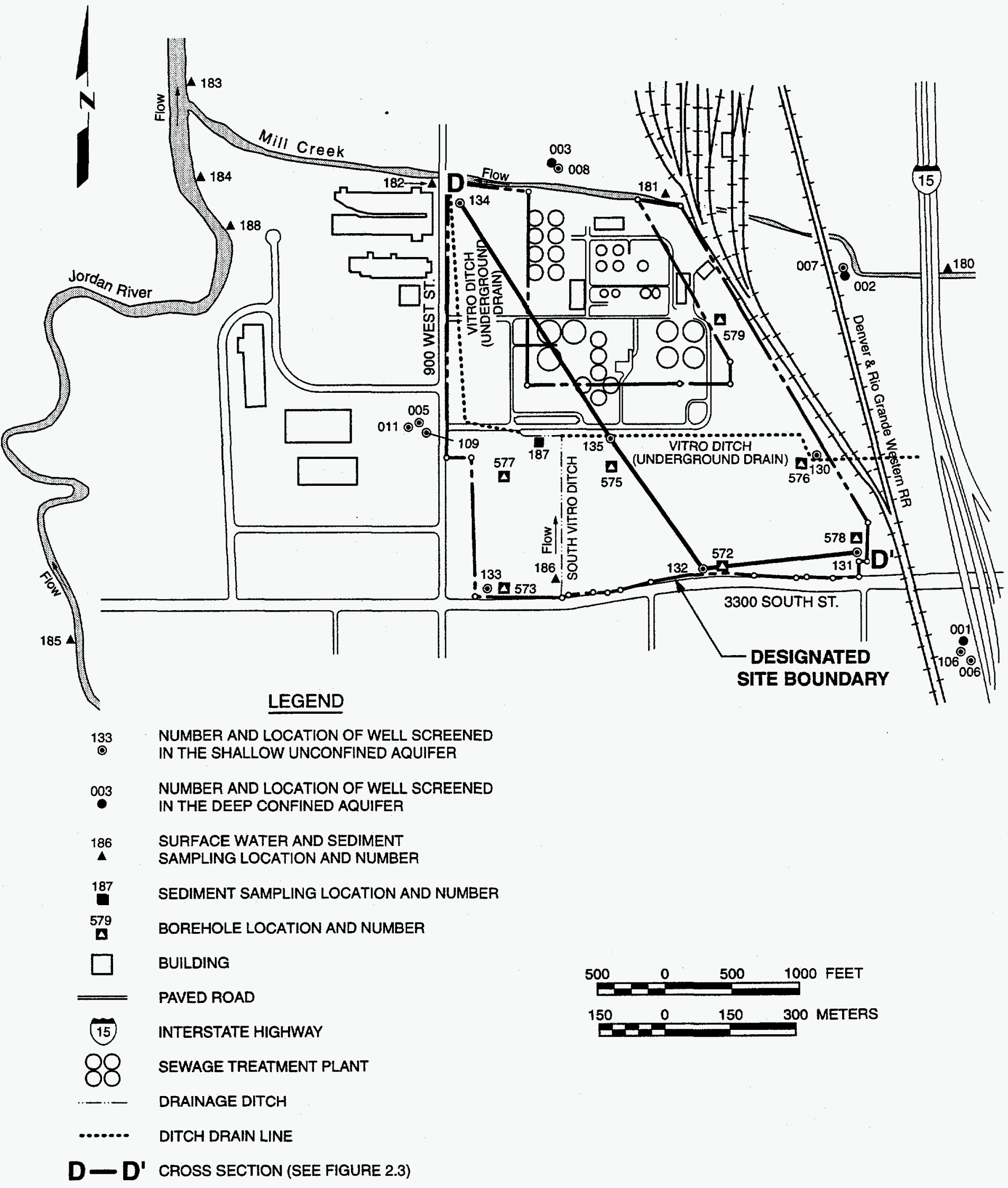

FIGURE 2.2

MONITOR WELL, SURFACE WATER, SEDIMENT, AND BOREHOLE SAMPLING LOCATIONS, SALT LAKE CITY, UTAH, SITE 


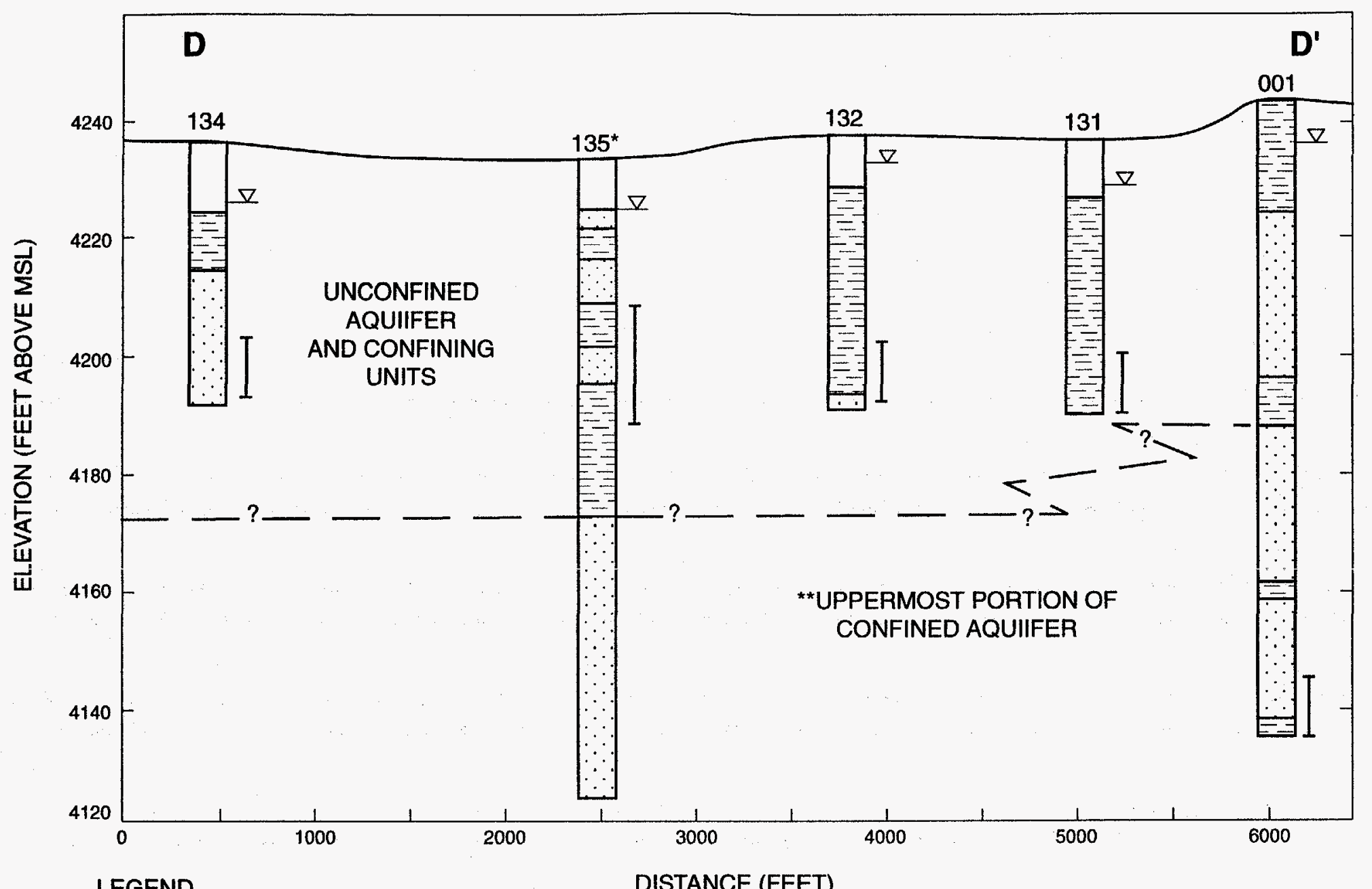

134 WELL DESCRIPTION

FILL

WATER BEARING UNITS

(SAND AND SILTY SAND)

CONFINING UNITS

(CLAY AND SILTY CLAY)

SCREEN INTERVAL

$\checkmark$ GROUND WATER ELEVATION

(10/27/93)

FIGURE 2.3

NOTES: 1. ELEVATIONS AND DISTANCES GIVEN IN

FEET TO CONVERT FROM FEET TO METERS, MULTIPLY FEET BY 0.3048

2. SEE FIGURE 2.2 FOR LINE OF SECTION.

*GEOLOGIC INFORMATION FROM ADJACENT BOREHOLE G135.

**PRODUCTIVE PORTION OF THE CONFINED AQUIFER BEGINS BELOW 200 FEET.

HYDROSTRATIGRAPHIC UNITS IN MONITOR WELLS, CROSS SECTION D-D' SALT LAKE CITY, UTAH, SITE 


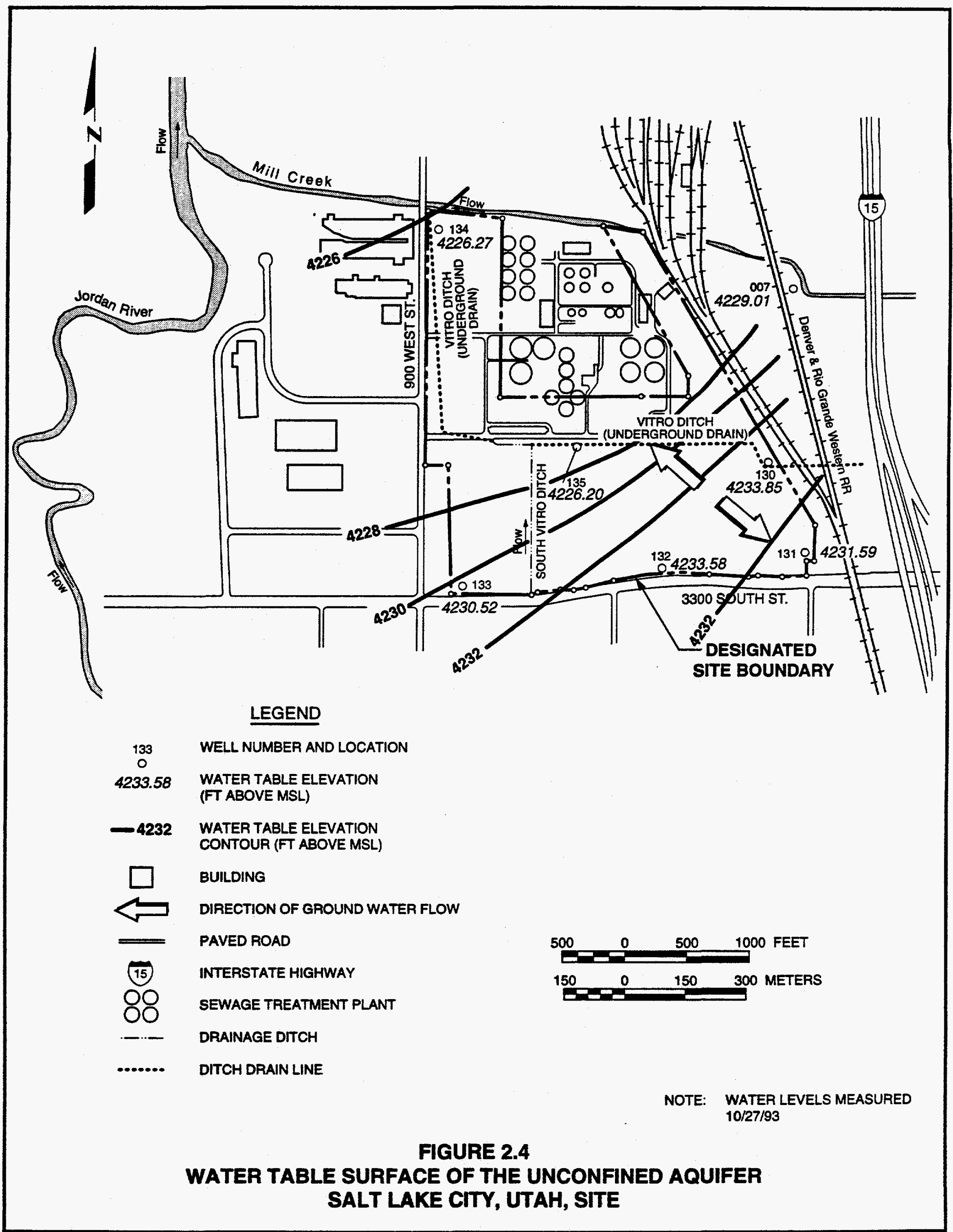


A 28-acre (ac) (11-hectare [ha]) golf driving range has been constructed in the southeast corner of the site. Irrigation of the golf course has a potential to recharge the shallow unconfined aquifer.

Ground water levels in the unconfined aquifer range from 5 to $15 \mathrm{ft}$ (1.5 to $4.6 \mathrm{~m}$ ) or more below the ground surface. The water level is highest in March or April and lowest in mid-to-late summer. Topographic lows east of the site are perennially marshy. The ground water flows primarily from southeast to northwest. Figure 2.4 shows a water table map of the shallow unconfined aquifer.

The hydraulic conductivities, determined from slug tests and an aquifer test conducted in 1992, ranged from 0.37 to $8.9 \mathrm{ft}(0.11$ to $2.7 \mathrm{~m})$ per day (Calculation No. SLC-07-92-14-03-00; TAC, 1992). A range of average linear ground water velocities in the shallow unconfined aquifer was calculated using the range of hydraulic conductivities, a hydraulic gradient of 0.005 , and an assumed effective porosity of 0.20 . Using Darcy's Law, the average linear velocity for ground water flow in the shallow unconfined aquifer ranges from approximately 3 to $80 \mathrm{ft}(1$ to $30 \mathrm{~m})$ per year.

\subsubsection{Confined aquifer}

The confined aquifer begins $70 \mathrm{ft}(20 \mathrm{~m})$ below the ground surface. Ground water is in this aquifer under substantial artesian pressure. Hydraulic head levels range from approximately $8 \mathrm{ft}(2.5 \mathrm{~m})$ above the ground surface for the well screened at $70 \mathrm{ft}(20 \mathrm{~m})$ to $15 \mathrm{ft}(4.5 \mathrm{~m})$ above ground surface for the wells screened at a depth of approximately $130 \mathrm{ft}(40 \mathrm{~m})$. Near the Jordan River, this confined (artesian) aquifer system extends to depths of 500 to $800 \mathrm{ft}(150$ to $240 \mathrm{~m}$ ) below the ground surface (Hely et al., 1971).

The major source of recharge to the confined aquifer is precipitation infiltration and snowmelt along the flanks of the Wasatch and Oquirrh Mountains. Beneath the site, the ground water in this aquifer flows west-northwest. Natural discharge is upward to the unconfined aquifer system. Artificial discharge includes pumpage of wells completed in the confined aquifer system. A potentiometric contour map of the deeper confined aquifer was not constructed because there were too few data to contour.

The relatively good water quality of the confined aquifer is maintained by the upward vertical hydraulic gradient between the two aquifers, which prevents downward water migration from the unconfined aquifer. The potential for contamination of the confined aquifer exists, however, if hydraulic head in the confined aquifer declines so that the direction of flow between the two aquifers reverses. Localized water could percolate from the shallow-unconfined aquifer into the confined aquifer in the area of the cone of depression caused by largescale pumping from wells developed in the confined aquifer. Because of the aquifer heterogenicity, the actual effects of large-scale pumping are difficult to predict with available data. 
Four surface water bodies are near or at the Salt Lake City site. The Jordan River is about $1500 \mathrm{ft}(460 \mathrm{~m})$ west of the site and flows north to the Great Salt Lake. Mill Creek, a perennial stream, flows along the north edge of the site. This creek empties directly into the Jordan River. Two flowing drainages are on the Salt Lake City site (Figure 2.2). Vitro Ditch drains a marshy area on the Denver \& Rio Grande Western Railroad property immediately east of the site. Prior to surface remediation, Vitro Ditch was an open Ditch crossing the site from east to west and continuing west to the Jordan River. After remediation, the Ditch was replaced by a drain pipe beneath the site and the discharge point was changed to Mill Creek. Thus, at present, the drainage enters the drain on the east edge of the site, runs from east to west across the site, and discharges to the north end of South Vitro Ditch. South Vitro Ditch is an open drainage Ditch that runs from south to north across the site, where it intersects with Vitro Ditch. About $50 \mathrm{ft}(20 \mathrm{~m})$ downstream of that point, the combined flow enters another drain pipe which ultimately discharges to Mill Creek near the far northwest corner of the site. This point of discharge is immediately downstream from the Central Valley Water Reclamation Facility (CVWRF) point of discharge for treated effluent. The CVWRF contributes about 200 million gallons (gal) (800 million liters [L]) per day of treated water to Mill Creek.

Ground water elevations in monitor wells located along the south boundary of the site are at or above the level of the South Vitro Ditch bed; therefore, ground water may recharge the ditch near its south (upstream) end. South Vitro Ditch receives drainage from the storm sewers that drain 3300 South Street. The sewer system includes a sump pump located at the bottom of a railway underpass on 3300 South Street. Water levels in the sewer at the bottom of the underpass are about $24 \mathrm{ft}(7 \mathrm{~m})$ below water levels on site, and thus there is the potential for contaminated ground water to discharge to the sewer system, and hence to South Vitro Ditch.

\section{$2.5 \quad$ LAND USE}

The 128-ac (52-ha) former processing site is in a primarily urban area in the city of South Salt Lake. As the metropolitan area expanded, the area around the Vitro site changed from agricultural and limited residential use to industrial use.

The entire site is owned by the CVWRF, except for a $25 \times 25-\mathrm{ft}(8 \times 8-\mathrm{m})$ strip of land surrounding the municipal water well, and an easement, which is owned by the city of South Salt Lake. A 28-ac (11-ha) portion of the land in the southeast corner of the site has been leased and developed into a golf driving range. The remaining land is currently vacant but will probably be developed as an industrial, commercial, or recreational area. Figure 2.5 shows land use within a radius of about $0.5 \mathrm{mi}(0.8 \mathrm{~km})$ from the site. 


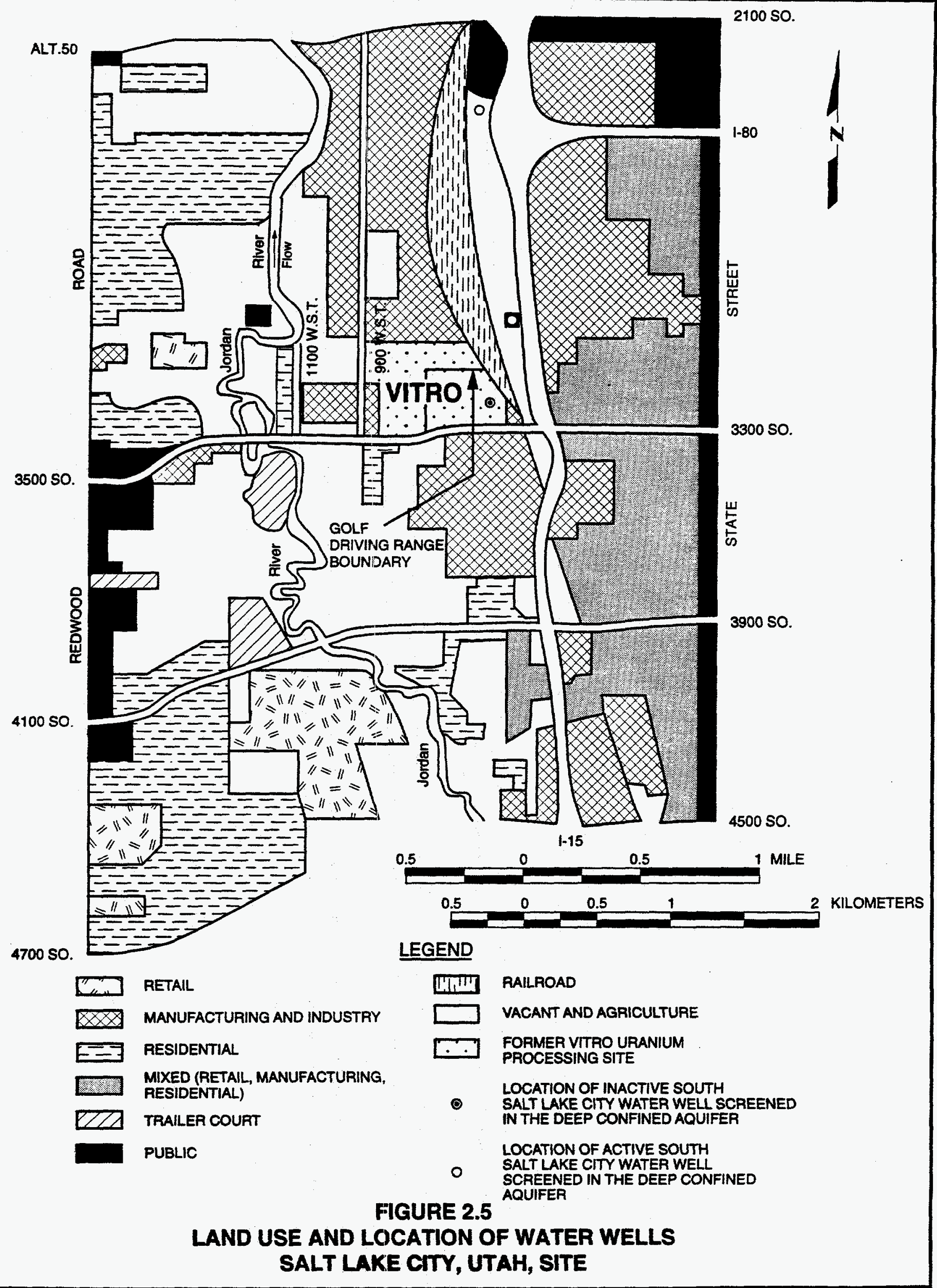


The CVWRF sewage treatment plant (on adjacent property north of the central portion of the site) and the channel of Mill Creek are north of the driving range. Warehouses and Denver \& Rio Grande Western Railroad property are still farther north.

The railroad also occupies the land on the east side of the site. This property extends as far as Interstate 15. A cement plant is at the southeastern corner of the site.

On the south, the site is bounded by 3300 South Street. The land across 3300 South Street is occupied mainly by car dealerships and junk car yards. A mixed residential and farming area, consisting of about 20 to 25 residences, is about $300 \mathrm{ft}(90 \mathrm{~m})$ away from the site's southwestern corner, across 3300 South Street. These are the nearest residences to the Salt Lake City site. Livestock is kept by some of these residents. Cattle and horses graze on the nearby fields.

On the west, the site is bounded by 900 West Street. The Jordan River controls land-use patterns further west. This area includes light industry, commercial developments, and vacant land, with about 10 residences on 1100 West Street. Ducks, geese, and horses are kept at some of these residences. An apartment complex, a correction facility, and a recreation area associated with the Jordan River are the other developments in the region.

\subsection{WATER USE}

A ground water-well records search and field reconnaissance were conducted in April 1994, at and near the former uranium processing site. Detailed examination of the state engineer's data base and intensive field investigation downgradient from the site did not reveal any users of the shallow-unconfined aquifer ground water within a $1-\mathrm{mi}(1.6)$ radius of the site (TAC, 1994). The shallow unconfined aquifer seldom is used in the area for domestic (potable) purposes because it yields water slowly and the water is of poor quality (USGS, 1984: DNR, 1971). Shallow wells installed for use as a potable water supply must meet potable water quality standards issued by the state of Utah and enforced by the Salt Lake City county (SLCC, 1981; Minor, 1995). However, the standards and regulations applied to individual wells or a certain type of use are not clear.

Residences and small businesses in the site vicinity use the municipal water supply system. Some residents living about $0.25 \mathrm{mi}(400 \mathrm{~m})$ west of and downgradient from the site (on South 1100 West Street) use domestic wells completed in the deep-confined aquifer (from 100 to $300 \mathrm{ft}(30$ to $90 \mathrm{~m})$ below the land surface). None of these wells is currently used for drinking water. One well was used to irrigate a garden but appears to be sanded up and now produces only a trickle of water. 
City (South Salt Lake) water lines serve the area of the former mill site and the area east of the site. The city obtains water from five operating water wells completed in the confined (artesian aquifer). Location of two of these wells is shown in Figure 2.5. The municipal water wells range from 800 to $1000 \mathrm{ft}$ $(240$ to $300 \mathrm{~m})$ deep, but they generally are perforated from 400 to $800 \mathrm{ft}$ $(120$ to $240 \mathrm{~m})$.

Water from the wells is pumped to an underground reservoir lat 1300 East Street) where it is gravity-fed into the water lines. The state of Utah samples and tests the water once a month. Other than transient coliform contamination, the water has always met drinking water standards. Therefore, no water treatment is necessary except chlorination. Areas west of the site are served by the water lines of the Water Conservancy District, which uses Salt Lake City or county water wells.

In 1985, the CVWRF sold the water rights to four on-site wells to the city of South Salt Lake. These wells had been owned by the Vitro Uranium Company. One of these wells, a 10-inch cased well, is in the southeast corner of the site. The city may attempt to develop this well as a source for the municipal water supply system. The city has water rights for 2.67 cubic feet $\left(\mathrm{ft}^{3}\right)(0.08$ cubic meters $\left.\left[\mathrm{m}^{3}\right]\right)$ per second. The remaining three wells have been abandoned.

Because the state of Utah is concerned about the potential movement of contamination into the confined aquifer beneath the site, pumping from the on-site city well, should it occur, will be limited so as to prevent gradient reversal. Before full-scale production pumping begins, a geophysical survey must be completed to ensure well integrity. Water quality in the well will be evaluated every six months. During the first 6 months of pumping, the flow will be limited to $1 \mathrm{ft}^{3}\left(0.03 \mathrm{~m}^{3}\right)$ per second and drawdown shall not exceed $60 \mathrm{ft}$ $(18 \mathrm{~m})$ below ground surface. The water will be retested after 6 months of pumping. If the surrounding wells and the ground water chemistry show no signs of contamination, pumping will continue for another 6 months. After that, the state of Utah may approve an increase in production rate. It may restrict pumping if the well shows negative impacts from drawdown and/or if the water chemistry changes.

The city of South Salt Lake supplies irrigation water for about 25 ac (10 ha) of grass at the driving range at the former mill site. However, the treated water obtained from CVWRF will be used to irrigate the driving range in the future. Approximately 1 acre-foot is used for irrigation during the summer. 


\subsection{EXTENT OF CONTAMINATION}

Ground water quality data from the unconfined aquifer were collected from 1982 through 1988 from a total of 37 monitor wells and from August 1990 through February 1994 from 11 monitor wells (DOE, 1995a). One additional monitor well (106) was sampled for organic contaminants in 1990. Because trace element data collected prior to 1990 are particularly unreliable, pre-1990 data were used only to document trends in major-element chemistry.

Between August 1990 and February 1994, the DOE collected ground water samples from 11 monitor wells (DOE, 1995a). The data were used to establish background and contaminated ground water chemistry in the unconfined aquifer. This time period allowed for incorporation of at least 3 years of data from each well while using the most recent information available for the aquifer. Figure 2.2 shows the locations of these monitor wells. Table 3.1 provides well completion data for these wells. Filtered ground water samples were analyzed for inorganic constituents. One round of unfiltered water samples was collected from well 131 in 1992 and analyzed for inorganic constituents. Comparing those data to filtered samples data indicates some constituents were present at levels greater than the highest levels reported for filtered water samples within the contamination zone. These constituents are aluminum (28 milligrams per liter $[\mathrm{mg} / \mathrm{L}])$, iron $(41 \mathrm{mg} / \mathrm{L})$, chromium $(0.029 \mathrm{mg} / \mathrm{L})$, copper $(0.137 \mathrm{mg} / \mathrm{L})$, and lead $(0.086 \mathrm{mg} / \mathrm{L})$. There are not enough unfiltered samples to verify these data. However, this well was newly completed at the time of sampling and produced a large amount of bentonite drilling mud. Therefore, the unfiltered data may not represent the true influence of very fine solid particles (colloids) on water chemistry within the contaminant plume. Thus, there are not enough unfiltered samples to assess the influence of colloids on ground water chemistry. Collection of additional unfiltered samples will be addressed in future field plans.

In 1990, a screening for organic contaminants was conducted. Monitor wells 008, 011 , and 106 were sampled and analyzed for all organic hazardous constituents listed in Appendix IX to 40 CFR Part 264 (1994) of the Resource Conservation and Recovery Act. None of these hazardous organics were detected in the screening (DOE, 1995a).

The DOE sampled four monitor wells within the confined aquifer from 1990 through 1993 (Figure 2.2). Well information is summarized in Table 3.1, and water quality data are summarized in Table 3.2. Water quality in the confined aquifer varies in the region. Water with low total dissolved solids (TDS) (less than $250 \mathrm{mg} / \mathrm{L}$ ) occurs near the point of recharge (about $9 \mathrm{mi}$ [14.15 km] southeast of the site) and increases to as much as $20,000 \mathrm{mg} / \mathrm{L}$ toward the Great Salt Lake (Hely et al., 1971). In the site area, TDS in the confined aquifer range from 100 to $500 \mathrm{mg} / \mathrm{L}$, with areas of high TDS west and north of the site (Hely et al., 1971).

One round of surface water and sediment samples was taken in December 1993. The surface water data were used to make a preliminary evaluation of surface water contamination. These data are for unfiltered surface water samples collected at the locations shown in Figure 2.2. 
Table 3.1 Monitor wells used to determine water quality in the unconfined and confined aquifers

\begin{tabular}{|c|c|c|c|c|c|}
\hline \multirow[b]{2}{*}{ Well } & \multirow[b]{2}{*}{ Location } & \multicolumn{2}{|c|}{$\begin{array}{c}\text { Screened interval } \\
\text { (depth below surface) }\end{array}$} & \multirow[t]{2}{*}{$\begin{array}{c}\text { Year } \\
\text { sampled }\end{array}$} & \multirow{2}{*}{$\begin{array}{c}\text { Number of } \\
\text { sampling } \\
\text { rounds }\end{array}$} \\
\hline & & (ft) & (m) & & \\
\hline \multicolumn{6}{|c|}{ Unconfined aquifer } \\
\hline 006 & Off-site upgradient & $26-28$ & $7.9-8.5$ & 83,94 & 3 \\
\hline 007 & Off-site crossgradient & $26-28$ & $7.9-8.5$ & $83-94$ & 11 \\
\hline 008 & Off-site downgradient & $26-28$ & $7.9-8.5$ & $86-93$ & 9 \\
\hline $011^{a}$ & Off-site downgradient & $24-26$ & 7.3-79 & $83-92$ & 9 \\
\hline $106^{a}$ & Off-site upgradient & $18-20$ & $5.5-6.1$ & $83-90$ & 4 \\
\hline $109^{a}$ & Off-site downgradient & $16-18$ & $4.9-5.4$ & $83-92$ & 9 \\
\hline 130 & On-site crossgradient & $31.8-41.8$ & $9.7-12.7$ & $92-94$ & 4 \\
\hline 131 & On-site downgradient & $34.7-44.7$ & $10.6-13.6$ & $92-94$ & 4 \\
\hline 132 & On-site crossgradient & $36.3-46.3$ & $12.4-14.1$ & $92-94$ & 4 \\
\hline 133 & On-site crossgradient & $35.0-45.0$ & $10.7-13.7$ & $92-94$ & 4 \\
\hline 134 & On-site crossgradient & $32.2-42.2$ & $9.8-12.9$ & $92-94$ & 4 \\
\hline 135 & On-site crossgradient & $25.5-45.5$ & $7.8-13.9$ & $92-94$ & 4 \\
\hline \multicolumn{6}{|c|}{ Confined aquifer } \\
\hline 001 & Off-site south & $100-110$ & $30.5-33.5$ & $86-92$ & 6 \\
\hline 002 & Off-site northeast & $119-129$ & $36.3-39.3$ & $86-93$ & 7 \\
\hline 003 & Off-site north & $110-120$ & $33.5-36.6$ & $86-93$ & 7 \\
\hline 005 & Off-site west & $115.5-125.5$ & $35.2-38.3$ & $83-90$ & 3 \\
\hline
\end{tabular}

${ }^{\mathrm{a} D e c o m m i s s i o n e d}$ well. 
Table 3.2 Water quality of the confined aquifer, Salt Lake City, Utah, site

\begin{tabular}{|c|c|c|c|c|}
\hline \multirow[b]{2}{*}{ Parameter } & \multicolumn{4}{|c|}{ Monitor well } \\
\hline & 001 & 002 & 003 & 004 \\
\hline Alkalinity $^{\mathrm{a}}$ & 262 & 282 & 242 & 200 \\
\hline Aluminum & $<0.1$ & $<0.1$ & $<0.1$ & $<0.1$ \\
\hline Ammonium & 4.3 & 6.7 & 4.6 & 10.7 \\
\hline Antimony & $<0.003$ & $<0.003$ & $<0.003$ & $<0.003$ \\
\hline Arsenic & $<0.01$ & $<0.01$ & $<0.01$ & $<0.01$ \\
\hline Barium & 0.1 & 0.1 & 0.2 & 0.4 \\
\hline Beryllium & $<0.01$ & $<0.01$ & $<0.01$ & $<0.01$ \\
\hline Cadmium & $<0.001$ & $<0.001$ & $<0.001$ & $<0.001$ \\
\hline Calcium & 63 & 40 & 55 & 122 \\
\hline Chloride & 18 & 8 & 19 & 207 \\
\hline Chromium & $<0.01$ & $<0.01$ & $<0.01$ & $<0.01$ \\
\hline Cobalt & $<0.05$ & $<0.05$ & $<0.05$ & $<0.05$ \\
\hline Copper & $<0.02$ & $<0.02$ & $<0.02$ & $<0.02$ \\
\hline Fluoride & 0.2 & 0.3 & 0.2 & 0.2 \\
\hline Iron & 0.08 & 0.58 & 0.17 & 0.74 \\
\hline Lead & $<0.01$ & $<0.01$ & $<0.01$ & $<0.01$ \\
\hline Magnesium & 23 & 20 & 21 & 60 \\
\hline Manganese & 0.07 & 0.11 & 0.06 & 0.58 \\
\hline Mercury & $<0.0002$ & $<0.0002$ & $<0.0002$ & $<0.0002$ \\
\hline Molybdenum & $<0.01$ & $<0.01$ & $<0.01$ & $<0.01$ \\
\hline Nickel & $<0.04$ & $<0.04$ & $<0.04$ & $<0.04$ \\
\hline Nitrate $^{b}$ & $<1.0$ & $<1.0$ & $<1.0$ & $<1.0$ \\
\hline $\mathrm{pH}$ & 7.9 & 7.6 & 7.8 & 7.4 \\
\hline Potassium & 7 & 11 & 5 & 17 \\
\hline Radium-226 (pCi/L) & 0.1 & 0.1 & 0.0 & 0.4 \\
\hline Radium-228 (pCi/L) & 1.4 & 0.5 & 0.0 & 1.5 \\
\hline Selenium & $<0.005$ & $<0.005$ & $<0.005$ & $<0.005$ \\
\hline Silver & $<0.01$ & $<0.01$ & $<0.01$ & $<0.01$ \\
\hline Sodium & 20 & 35 & 20 & 36 \\
\hline Strontium & 0.7 & 0.4 & 0.7 & 1.2 \\
\hline Sulfate & 33 & $<0.1$ & 29 & 230 \\
\hline Sulfide & 0.3 & $<0.1$ & $<0.1$ & $<0.1$ \\
\hline Thallium & $<0.01$ & $<0.1$ & $<0.01$ & $<0.01$ \\
\hline
\end{tabular}


Table 3.2 Water quality of the confined aquifer, Salt Lake City, Utah, site (Concluded)

\begin{tabular}{lrrrr}
\hline & \multicolumn{4}{c}{ Monitor well } \\
\cline { 2 - 5 } \multicolumn{1}{c}{ Parameter } & 001 & 002 & 003 & \multicolumn{1}{c}{004} \\
\hline Thorium-230 (pCi/L) & 0.0 & 0.0 & 0.0 & 0.0 \\
Tin & $<0.005$ & $<0.005$ & $<0.005$ & $<0.005$ \\
TDS & $\mathrm{NA}$ & 308 & 251 & $\mathrm{NA}$ \\
Uranium & 0.0003 & 0.0003 & $<0.0003$ & $<0.0003$ \\
Vanadium & 0.01 & 0.01 & 0.01 & $<0.01$ \\
Zinc & $<0.005$ & $<0.005$ & $<0.005$ & $<0.005$ \\
\hline
\end{tabular}

${ }^{a}$ Alkalinity as $\mathrm{mg} / \mathrm{L} \mathrm{CaCO}_{3}$.

${ }^{b}$ Nitrate expressed as $\mathrm{NO}_{3}$.

Notes:

1. Filtered samples collected 8 August 1990 , at the site periphery.

2. Results of the most recent complete sampling round.

3. All data in milligrams per liter unless noted as picocuries per liter $(\mathrm{pCi} / \mathrm{L})$.

NA - not available. 


\subsection{BACKGROUND WATER QUALITY SUMMARY}

Background water quality is defined as the water quality if uranium milling activities had not occurred. There are two hydrologic systems at the site: a deep, confined aquifer and a shallow unconfined aquifer. The unconfined aquifer clearly has received contaminants from the former tailings piles and ponds. In contrast, in the confined aquifer, which was sampled near the property boundaries to the southeast, northeast, north, and west (Figure 2.2), radioactive constituents or metals that could be associated with tailings have not been found at levels above background determined for the unconfined aquifer (Table 3.2).

None of the DOE monitor wells in the confined aquifer are designated as background because the local ground water flow direction is not known in the confined aquifer (Section 2.3). The TDS in the confined aquifer at the site range from 251 to $1400 \mathrm{mg} / \mathrm{L}$ (Table 3.2). The more saline water is found in monitor well 005, on the west side of the site. This well water has the highest sulfate and chloride levels of the four confined aquifer monitor wells. Historical data also show higher sulfate, chloride, and TDS levels in the area west of the site within the confined aquifer. The concentrations of uranium, molybdenum, and other metals are low in monitor well 005 and the other confined aquifer wells, with a range about equal to the unconfined aquifer background well (007). Thus, the lack of uranium and molybdenum above background suggests that the higher salinity in the confined aquifer west of the site is due to natural variability.

A former Vitro water production well, now owned by the city of South Salt Lake and being considered for use as a municipal water supply, produces water from the confined aquifer beneath the site. This flowing well is $710 \mathrm{ft}(216 \mathrm{~m})$ deep and is in the southeast portion of the site (Figure 2.2). Table 3.3 summarizes water quality data from samples taken February 1985 and July 1989 during testing of the well. The data were obtained from the Utah Division of Drinking Water. The city well samples a much larger and deeper portion of the confined aquifer and may represent an average of the natural variation in water quality of the confined aquifer. Thus, the water chemistry falls within the range of DOE monitor wells sampled in the confined aquifer. Uranium was not analyzed for; however, gross alpha measurements indicate uranium concentrations are less than 2 picocuries per liter $(\mathrm{pCi} / \mathrm{L}$ ) equivalent to less than $0.003 \mathrm{mg} / \mathrm{L}$ natural uranium. Thus, the ability of the upward gradient to prevent downward contamination migration is supported by the lack of site-related contamination in this well.

In the unconfined aquifer, DOE monitor well 007 is off and crossgradient of the site. Monitor well 007 has been sampled repeatedly since 1990. 
Table 3.3 Ground water quality data, city of South Salt Lake proposed municipal water supply well, Salt Lake City, Utah, site

\begin{tabular}{|c|c|c|}
\hline \multirow[b]{2}{*}{ Parameter } & \multicolumn{2}{|c|}{ Concentration (mg/L) } \\
\hline & August 1989 & February 1985 \\
\hline Aluminum & NA & $\overline{N A}$ \\
\hline Ammonium & $<0.3$ & NA \\
\hline Antimony & NA & NA \\
\hline Arsenic & $<0.001^{\mathrm{a}}$ & $<0.001$ \\
\hline Barium & $0.03^{a}$ & 0.03 \\
\hline Beryllium & NA & NA \\
\hline Boron & 0.03 & 0.06 \\
\hline Cadmium & $<0.001^{a}$ & $<0.001$ \\
\hline Calcium & 51 & 66 \\
\hline Chloride & 12 & 10 \\
\hline Chromium & $<0.001^{a}$ & 0.002 \\
\hline Cobalt & NA & NA \\
\hline Copper & $<0.01^{a}$ & $<0.01$ \\
\hline Cyanide & NA & NA \\
\hline Fluoride & 0.32 & 0.36 \\
\hline Iron & $<0.03^{a}$ & $0.15^{\mathrm{a}}$ \\
\hline Lead & $<0.001$ & $<0.001$ \\
\hline Magnesium & 20 & 20 \\
\hline Manganese & 70 & 80 \\
\hline Mercury & $<0.02^{\mathrm{a}}$ & $<0.02^{\mathrm{a}}$ \\
\hline Molybdenum & NA & NA \\
\hline Nickel & $<0.03^{\mathrm{a}}$ & $<0.01$ \\
\hline Nitrate as $\mathrm{NO}_{3}$ & $<0.09$ & $<0.04$ \\
\hline Potassium & 2 & 2 \\
\hline Selenium & $<0.001^{\mathrm{a}}$ & $<0.001$ \\
\hline Silver & $<0.001^{a}$ & $<0.001$ \\
\hline Sodium & 22 & 23 \\
\hline Strontium & NA & NA \\
\hline Sulfate & 80 & 108 \\
\hline Sulfide & NA & NA \\
\hline Thallium & NA & NA \\
\hline $\operatorname{Tin}$ & NA & NA \\
\hline
\end{tabular}


Table 3.3 Ground water quality data, city of South Salt Lake proposed municipal water supply well, Salt Lake City, Utah, site (Concluded)

\begin{tabular}{lcc}
\hline & \multicolumn{2}{c}{ Concentration (mg/L) } \\
\cline { 2 - 3 } \multicolumn{1}{c}{ Parameter } & August 1989 & February 1985 \\
\hline Uranium & NA & NA \\
Vanadium & NA & $<0.001$ \\
Zinc & $<0.01^{\text {a }}$ \\
& & \\
Radionuclide & (pCi/L) & (pCi/L) \\
Lead-210 & NA & NA \\
Polonium-230 & NA & NA \\
Radium-226 & NA & NA \\
Thorium-230 & NA & NA \\
Gross alpha & $<2$ & $<2$ \\
Gross beta & $<3$ & $<3$ \\
\hline
\end{tabular}

anfiltered water samples. All other data are for filtered samples.

NA - not available. 
Regionally, TDS values in the unconfined aquifer average about $1250 \mathrm{mg} / \mathrm{L}$. In the site vicinity, shallow ground water TDS values range from 1000 to $2000 \mathrm{mg} / \mathrm{L}$ (Seiler and Waddell, 1983). TDS values in ground water from monitor well 007 range from 500 to $600 \mathrm{mg} / \mathrm{L}$, which is actually less saline than normal for the shallow aquifer.

The relatively low salinity of ground water in well 007 may be caused by areal variations in salinity or by vertical salinity gradient in the shallow unconfined aquifer. In the areas near monitor well 007, ground water salinity increases dramatically in the upper $20 \mathrm{ft}(6 \mathrm{~m})$ of the aquifer. In the well cluster associated with monitor well 007 (wells 002,007, 107, and 157, all sampled in 1983) salinities vary from $290 \mathrm{mg} / \mathrm{L}$ within the confined aquifer at $120 \mathrm{ft}(37 \mathrm{~m})$ below land surface to $4600 \mathrm{mg} / \mathrm{L}$ near the top of the unconfined aquifer at $8 \mathrm{ft}$ $(2.4 \mathrm{~m})$ below land surface.

As discussed in Section 2.3.1, the unconfined aquifer probably is recharged both by vertical leakage of ground water from the confined aquifers and by surface recharge from rainfall and irrigation. The increased salinity near the top of the unconfined aquifer probably represents dissolved solids concentrated by evapotranspiration. Therefore, the relatively low salinity of well 007 (compared to regional ground water) may be because it is completed in the deeper, lowersalinity portion of the unconfined aquifer.

Ground water in monitor well 007 is a sodium-bicarbonate-type water; it is in equilibrium with calcium carbonate, magnesium carbonate, and barium sulfate (barite). The $\mathrm{pH}$ is slightly basic (near 8 ) and the Eh is slightly oxidizing (100 millivolts).

Table 3.4 provides a statistical summary of water quality data for monitor well 007 (background).

Most constituents commonly associated with ground water contamination from uranium mill tailings are below detection in well 007. However, two constituents commonly associated with uranium mill tailings, arsenic and ammonium, are present at levels above detection in the background ground water in this well. Arsenic is known to occur naturally in the shallow aquifer throughout the region (USGS, 1984). Regionally, arsenic averages about $0.05 \mathrm{mg} / \mathrm{L}$. Several possible sources are the past use of arsenic-bearing pesticides, flue dust from copper smelters, and Quaternary sediments derived from arsenic-bearing sulfide deposits in the mountains east and southwest of the site. In well 007, arsenic averaged about $0.05 \mathrm{mg} / \mathrm{L}$ and ammonium averaged $7.7 \mathrm{mg} / \mathrm{L}$ since 1990. The combination of arsenic and ammonium suggests that the source of these two contarninants may have been agricultural, related to the past use of pesticides and fertillizers. 
Table 3.4 Comparison of background and on-site ground water quality data in the unconfined aquifer at the Salt Lake City, Utah, site, August 1990 - February 1994, filtered water samples

\begin{tabular}{|c|c|c|c|c|}
\hline \multirow{2}{*}{ Parameter $^{\mathbf{b}}$} & \multirow{2}{*}{$\begin{array}{c}\text { Detection } \\
\text { frequency }^{c}\end{array}$} & \multicolumn{3}{|c|}{ Concentration $^{\mathrm{a}}$} \\
\hline & & Minimum & Median $^{\mathrm{a}}$ & Maximum \\
\hline Inorganic constituen & & & & \\
\hline $\begin{array}{l}\text { Aluminum } \\
\text { Background } \\
\text { Plume }\end{array}$ & $\begin{array}{r}1 / 6 \\
1 / 24\end{array}$ & $\begin{array}{l}<0.05 \\
<0.05\end{array}$ & $\begin{array}{l}\mathrm{e} \\
\mathrm{e}\end{array}$ & $\begin{array}{l}0.10 \\
0.40\end{array}$ \\
\hline $\begin{array}{l}\text { Ammonium }{ }^{\dagger} \\
\text { Background } \\
\text { Plume (well 008) }\end{array}$ & $\begin{array}{l}5 / 5 \\
5 / 5\end{array}$ & $\begin{array}{r}6.1 \\
10.9\end{array}$ & $\begin{array}{r}7.7 \\
12.6\end{array}$ & $\begin{array}{l}11.8 \\
20.9\end{array}$ \\
\hline $\begin{array}{l}\text { Antimony } \\
\text { Background } \\
\text { Plume }\end{array}$ & $\begin{array}{r}1 / 6 \\
11 / 24\end{array}$ & $\begin{array}{l}<0.003 \\
<0.003\end{array}$ & $\begin{array}{l}\mathrm{e} \\
\mathrm{e}\end{array}$ & $\begin{array}{l}0.025 \\
0.027\end{array}$ \\
\hline $\begin{array}{l}\text { Arsenic } \\
\text { Background } \\
\text { Plume }\end{array}$ & $\begin{array}{r}7 / 7 \\
14 / 27\end{array}$ & $\begin{array}{r}0.027 \\
<0.025\end{array}$ & $\begin{array}{l}0.050 \\
0.006\end{array}$ & $\begin{array}{l}0.061 \\
0.133\end{array}$ \\
\hline $\begin{array}{l}\text { Barium }^{f} \\
\text { Background } \\
\text { Plume (well 134) }\end{array}$ & $\begin{array}{l}6 / 6 \\
3 / 3\end{array}$ & $\begin{array}{l}0.10 \\
0.44\end{array}$ & $\begin{array}{l}0.11 \\
0.47\end{array}$ & $\begin{array}{l}0.12 \\
0.61\end{array}$ \\
\hline $\begin{array}{l}\text { Beryllium } \\
\text { Background } \\
\text { Plume }\end{array}$ & $\begin{array}{r}0 / 5 \\
0 / 20\end{array}$ & $\begin{array}{l}<0.001 \\
<0.001\end{array}$ & $\begin{array}{l}\mathrm{e} \\
\mathrm{e}\end{array}$ & $\begin{array}{l}<0.01 \\
<0.01\end{array}$ \\
\hline $\begin{array}{l}\text { Cadmium } \\
\text { Background } \\
\text { Plume }\end{array}$ & $\begin{array}{r}0 / 7 \\
1 / 27\end{array}$ & $\begin{array}{l}<0.001 \\
<0.001\end{array}$ & e & $\begin{array}{r}<0.001 \\
0.001\end{array}$ \\
\hline $\begin{array}{l}\text { Calcium }^{\dagger} \\
\text { Background } \\
\text { Plume (well 008) }\end{array}$ & $\begin{array}{l}7 / 7 \\
6 / 6\end{array}$ & $\begin{array}{l}11 \\
29\end{array}$ & $\begin{array}{r}12 \\
217\end{array}$ & $\begin{array}{r}13 \\
426\end{array}$ \\
\hline $\begin{array}{l}\text { Chloride }^{\dagger} \\
\text { Background } \\
\text { Plume (well 135) }\end{array}$ & $\begin{array}{l}7 / 7 \\
4 / 4\end{array}$ & $\begin{array}{r}56 \\
2540\end{array}$ & $\begin{array}{r}62 \\
2680\end{array}$ & $\begin{array}{r}74 \\
2830\end{array}$ \\
\hline $\begin{array}{l}\text { Chromium } \\
\text { Background } \\
\text { Plume }\end{array}$ & $\begin{array}{r}0 / 5 \\
0 / 20\end{array}$ & $\begin{array}{l}<0.003 \\
<0.003\end{array}$ & $\begin{array}{l}\text { e } \\
\text { e }\end{array}$ & $\begin{array}{l}<0.05 \\
<0.02\end{array}$ \\
\hline $\begin{array}{l}\text { Cobalt } \\
\text { Background } \\
\text { Plume }\end{array}$ & $\begin{array}{r}0 / 5 \\
0 / 20\end{array}$ & $\begin{array}{l}<0.003 \\
<0.003\end{array}$ & $\begin{array}{l}\text { e } \\
\text { e }\end{array}$ & $\begin{array}{l}<0.05 \\
<0.10\end{array}$ \\
\hline
\end{tabular}


Table 3.4 Comparison of background and on-site ground water quality data in the unconfined aquifer at the Salt Lake City, Utah, site, August 1990 - February 1994, filtered water samples (Continued)

\begin{tabular}{|c|c|c|c|c|}
\hline \multirow[b]{2}{*}{ Parameter $^{b}$} & \multirow{2}{*}{$\begin{array}{l}\text { Detection } \\
\text { frequency }\end{array}$} & \multicolumn{3}{|c|}{ Concentration $^{\mathrm{a}}$} \\
\hline & & Minimum & Median & Maximum \\
\hline $\begin{array}{l}\text { Copper } \\
\text { Background } \\
\text { Plume }\end{array}$ & $\begin{array}{r}1 / 5 \\
2 / 20\end{array}$ & $\begin{array}{r}0.003 \\
<0.002\end{array}$ & $\begin{array}{l}\mathrm{e} \\
\mathrm{e}\end{array}$ & $\begin{array}{r}<0.02 \\
0.01\end{array}$ \\
\hline $\begin{array}{l}\text { Cyanide } \\
\text { Background } \\
\text { Plume }\end{array}$ & $\begin{array}{r}0 / 4 \\
0 / 14\end{array}$ & $\begin{array}{l}<0.01 \\
<0.01\end{array}$ & $\begin{array}{l}e \\
e\end{array}$ & $\begin{array}{l}<0.01 \\
<0.01\end{array}$ \\
\hline $\begin{array}{l}\text { Fluoride } \\
\text { Background } \\
\text { Plume (well 109) }\end{array}$ & $\begin{array}{l}6 / 6 \\
5 / 5\end{array}$ & $\begin{array}{l}0.7 \\
2.0\end{array}$ & $\begin{array}{l}0.7 \\
2.4\end{array}$ & $\begin{array}{l}0.8 \\
2.7\end{array}$ \\
\hline $\begin{array}{l}\operatorname{Iron}^{\dagger} \\
\text { Background } \\
\text { Plume (well 109) }\end{array}$ & $\begin{array}{l}7 / 7 \\
5 / 5\end{array}$ & $\begin{array}{l}0.04 \\
1.50\end{array}$ & $\begin{array}{l}0.12 \\
5.24\end{array}$ & $\begin{array}{l}0.25 \\
6.48\end{array}$ \\
\hline $\begin{array}{l}\text { Lead } \\
\text { Background } \\
\text { Plume }\end{array}$ & $\begin{array}{r}0 / 6 \\
2 / 23\end{array}$ & $\begin{array}{l}<0.001 \\
<0.003\end{array}$ & $\begin{array}{l}\text { e } \\
\text { e }\end{array}$ & $\begin{array}{r}<0.010 \\
0.008\end{array}$ \\
\hline $\begin{array}{l}\text { Magnesium }^{f} \\
\text { Background } \\
\text { Plume (well 135) }\end{array}$ & $\begin{array}{l}7 / 7 \\
4 / 4\end{array}$ & $\begin{array}{r}32 \\
757\end{array}$ & $\begin{array}{r}33 \\
808\end{array}$ & $\begin{array}{r}35 \\
900\end{array}$ \\
\hline $\begin{array}{l}\text { Manganese }^{f} \\
\text { Background } \\
\text { Plume (well 109) }\end{array}$ & $\begin{array}{l}7 / 7 \\
5 / 5\end{array}$ & $\begin{array}{l}0.03 \\
0.11\end{array}$ & $\begin{array}{l}0.04 \\
0.48\end{array}$ & $\begin{array}{l}0.04 \\
0.63\end{array}$ \\
\hline $\begin{array}{l}\text { Mercury } \\
\text { Background } \\
\text { Plume }\end{array}$ & $\begin{array}{r}0 / 4 \\
1 / 20\end{array}$ & $\begin{array}{l}<0.0001 \\
<0.0001\end{array}$ & $\begin{array}{l}e \\
e\end{array}$ & $\begin{array}{r}<0.0002 \\
0.0002\end{array}$ \\
\hline $\begin{array}{l}\text { Molybdenum } \\
\text { Background } \\
\text { Plume (well 131) }\end{array}$ & $\begin{array}{l}1 / 7 \\
2 / 3\end{array}$ & $\begin{array}{l}<0.004 \\
<0.01\end{array}$ & $\begin{array}{l}\mathrm{e} \\
0.88\end{array}$ & $\begin{array}{l}0.01 \\
0.94\end{array}$ \\
\hline $\begin{array}{l}\text { Nickel } \\
\text { Background } \\
\text { Plume }\end{array}$ & $\begin{array}{r}1 / 5 \\
0 / 20\end{array}$ & $\begin{array}{r}0.007 \\
<0.006\end{array}$ & $\begin{array}{l}\text { e } \\
\text { e }\end{array}$ & $\begin{array}{l}<0.04 \\
<0.08\end{array}$ \\
\hline $\begin{array}{l}\text { Nitrate } \\
\text { Background } \\
\text { Plume }\end{array}$ & $\begin{array}{r}5 / 6 \\
10 / 23\end{array}$ & $\begin{array}{l}<1.0 \\
<0.2\end{array}$ & $\begin{array}{l}1.7 \\
e\end{array}$ & $\begin{array}{l}5.5 \\
4.6\end{array}$ \\
\hline $\begin{array}{l}\text { Potassium }{ }^{f} \\
\text { Background } \\
\text { Plume (well 135) }\end{array}$ & $\begin{array}{l}7 / 7 \\
4 / 4\end{array}$ & $\begin{array}{r}26 \\
176\end{array}$ & $\begin{array}{r}29 \\
214\end{array}$ & $\begin{array}{r}32 \\
228\end{array}$ \\
\hline $\begin{array}{l}\text { Selenium } \\
\text { Background } \\
\text { Plume }\end{array}$ & $\begin{array}{r}0 / 7 \\
3 / 27\end{array}$ & $\begin{array}{l}<0.001 \\
<0.001\end{array}$ & $\begin{array}{l}\mathrm{e} \\
\mathrm{e}\end{array}$ & $\begin{array}{r}<0.005 \\
0.030\end{array}$ \\
\hline
\end{tabular}


Table 3.4 Comparison of background and on-site ground water quality data in the unconfined aquifer at the Salt Lake City, Utah, site, August 1990 - February 1994, filtered water samples (Continued)

\begin{tabular}{|c|c|c|c|c|}
\hline \multirow[b]{2}{*}{ Parameter $^{\mathrm{b}}$} & \multirow{2}{*}{$\begin{array}{l}\text { Detection } \\
\text { frequency }^{c}\end{array}$} & \multicolumn{3}{|c|}{ Concentration $^{\mathrm{a}}$} \\
\hline & & Minimum & Median & Maximum \\
\hline $\begin{array}{l}\text { Silver }^{\ddagger} \\
\text { Background } \\
\text { Plume }\end{array}$ & $\begin{array}{r}0 / 5 \\
6 / 20\end{array}$ & $\begin{array}{l}<0.002 \\
<0.010\end{array}$ & $\begin{array}{l}\mathrm{e} \\
\mathrm{e}\end{array}$ & $\begin{array}{r}<0.010 \\
0.041\end{array}$ \\
\hline $\begin{array}{l}\text { Sodium }{ }^{\dagger} \\
\text { Background } \\
\text { Plume (well 135) }\end{array}$ & $\begin{array}{l}7 / 7 \\
4 / 4\end{array}$ & $\begin{array}{r}129 \\
2490\end{array}$ & $\begin{array}{r}135 \\
2875\end{array}$ & $\begin{array}{r}150 \\
3160\end{array}$ \\
\hline $\begin{array}{l}\text { Strontium }{ }^{f} \\
\text { Background } \\
\text { Plume (well 135) }\end{array}$ & $\begin{array}{l}6 / 6 \\
3 / 3\end{array}$ & $\begin{array}{l}0.20 \\
4.16\end{array}$ & $\begin{array}{l}0.20 \\
4.24\end{array}$ & $\begin{array}{l}0.55 \\
4.39\end{array}$ \\
\hline $\begin{array}{l}\text { Sulfate }^{f} \\
\text { Background } \\
\text { Plume (well 135) }\end{array}$ & $\begin{array}{l}2 / 7 \\
4 / 4\end{array}$ & $\begin{aligned}<0.1 \\
4970\end{aligned}$ & $\begin{array}{r}e \\
5310\end{array}$ & $5560^{3.6}$ \\
\hline $\begin{array}{l}\text { Sulfide } \\
\text { Background } \\
\text { Plume }\end{array}$ & $\begin{array}{r}3 / 5 \\
4 / 20\end{array}$ & $\begin{array}{l}<0.1 \\
<0.1\end{array}$ & $\begin{array}{l}0.7 \\
\mathrm{e}\end{array}$ & $\begin{array}{l}2.3 \\
2.1\end{array}$ \\
\hline $\begin{array}{l}\text { Thallium } \\
\text { Background } \\
\text { Plume }\end{array}$ & $\begin{array}{r}0 / 5 \\
0 / 20\end{array}$ & $\begin{array}{l}<0.005 \\
<0.005\end{array}$ & $\begin{array}{l}\mathrm{e} \\
\mathrm{e}\end{array}$ & $\begin{array}{l}<0.067 \\
<0.340\end{array}$ \\
\hline $\begin{array}{l}\text { Tin } \\
\text { Background } \\
\text { Plume }\end{array}$ & $\begin{array}{r}1 / 5 \\
0 / 20\end{array}$ & $\begin{array}{l}<0.005 \\
<0.005\end{array}$ & $\begin{array}{l}e \\
e\end{array}$ & $\begin{array}{r}0.006 \\
<0.100\end{array}$ \\
\hline $\begin{array}{l}\text { Uranium }^{f} \\
\text { Background } \\
\text { Plume (well 109) }\end{array}$ & $\begin{array}{l}1 / 7 \\
5 / 5\end{array}$ & $\begin{array}{c}<0.0001 \\
0.160\end{array}$ & $\begin{array}{l}e \\
0.233\end{array}$ & $\begin{array}{l}0.009 \\
0.266\end{array}$ \\
\hline $\begin{array}{l}\text { Vanadium }^{\dagger} \\
\text { Background } \\
\text { Plume (well 135) }\end{array}$ & $\begin{array}{l}0 / 6 \\
2 / 3\end{array}$ & $\begin{array}{l}<0.005 \\
<0.010\end{array}$ & $\begin{array}{l}e \\
0.021\end{array}$ & $\begin{array}{r}<0.010 \\
0.071\end{array}$ \\
\hline $\begin{array}{l}\text { Zinc } \\
\text { Background } \\
\text { Plume }\end{array}$ & $\begin{array}{r}3 / 6 \\
11 / 24\end{array}$ & $\begin{array}{l}<0.005 \\
<0.005\end{array}$ & $\begin{array}{l}\text { e } \\
\text { e }\end{array}$ & $\begin{array}{l}0.018 \\
0.187\end{array}$ \\
\hline Radionuclide & & & & \\
\hline Lead-210 & & & & \\
\hline $\begin{array}{l}\text { Background } \\
\text { Plume }\end{array}$ & $\begin{array}{l}1 / 1 \\
4 / 4\end{array}$ & $\begin{array}{l}\text { NA } \\
0.0\end{array}$ & $\begin{array}{l}0.5 \\
0.55\end{array}$ & $\begin{array}{l}\text { NA } \\
1.1\end{array}$ \\
\hline Polonium-210 & & & & \\
\hline $\begin{array}{l}\text { Background } \\
\text { Plume }\end{array}$ & $\begin{array}{l}0 / 1 \\
4 / 4\end{array}$ & $\begin{array}{l}\text { NA } \\
0.0\end{array}$ & $\begin{array}{l}0.0 \\
0.05\end{array}$ & $\begin{array}{l}\text { NA } \\
0.2\end{array}$ \\
\hline
\end{tabular}


Table 3.4 Comparison of background and on-site ground water quality data in the unconfined aquifer at the Salt Lake City, Utah, site, August 1990 - February 1994, filtered water samples (Concluded)

\begin{tabular}{|c|c|c|c|c|}
\hline \multirow[b]{2}{*}{ Parameter ${ }^{b}$} & \multirow{2}{*}{$\begin{array}{l}\text { Detection } \\
\text { frequency }\end{array}$} & \multicolumn{3}{|c|}{ Concentration $^{\mathrm{a}}$} \\
\hline & & Minimum & Median ${ }^{d}$ & Maximum \\
\hline \multicolumn{5}{|l|}{ Radium-226 } \\
\hline Background & $5 / 5$ & 0.0 & 0.1 & 0.5 \\
\hline Plume & $20 / 20$ & 0.1 & 0.4 & 1.3 \\
\hline \multicolumn{5}{|l|}{ Radium-228 } \\
\hline Background & $4 / 5$ & 0.0 & 0.9 & 8.9 \\
\hline Plume & $18 / 18$ & 0.0 & 1.45 & 5.2 \\
\hline \multicolumn{5}{|l|}{ Thorium-230 } \\
\hline Background & $5 / 5$ & 0.0 & 0.2 & 0.9 \\
\hline Plume & $20 / 20$ & 0.0 & 0.3 & 0.8 \\
\hline
\end{tabular}

${ }^{a}$ Inorganic constituent concentrations are reported in milligrams per liter. Radionuclide concentrations are reported in picocuries per liter.

background well is 007 . Plume concentrations are from DOE wells 008, 011, 109, 131, 134, and 135, unless otherwise noted.

cNumber of samples with detectable concentration/total number of samples.

${ }^{d} 50$ th percentile of the data. Computation of the median requires that more than 50 percent of the data are above detection.

${ }^{\mathrm{e}}$ Median cannot be determined.

${ }^{f}$ Constituents are elevated in plume wells compared to background at the 0.05 level of significance. For these constituents, concentrations observed in highest plume wells are presented.

${ }^{9}$ Unfiltered samples. 


\subsection{MAGNITUDE OF SITE-RELATED CONTAMINATION}

The original tailings solutions within tailings piles and evaporation ponds were acid solutions ( $\mathrm{pH}$ less than 4) composed predominantly of aluminum sulfate and sodium chloride (Markos and Bush, 1982). Previous geochemical studies demonstrated that as the solutions migrated into the unconfined aquifer, they were immediately neutralized at the tailings-soil interface by the reaction of calcite and dolomite with the acid solution. This produced a thin zone of precipitates at the interface. This 4-inch (10-centimeter [cm]) zone includes gypsum, iron oxides, and basic iron and aluminum sulfates (Markos and Bush, 1982).

As a result of neutralization, precipitation, and $\mathrm{pH}$-dependent sorption, contaminated ground water within the unconfined aquifer contains relatively low concentrations of heavy metals and metalloids. It is recognized primarily by high concentrations of TDS and major ions including sulfate, chloride, calcium, magnesium, and sodium. Locally, the alkalinity is very high labout $1100 \mathrm{mg} / \mathrm{L}$ as calcium carbonate in well 135), reflecting the neutralization of the acid tailings solutions by carbonates. Compared to background waters, several trace elements are found to be present at elevated concentrations, including manganese, molybdenum, uranium, vanadium, strontium, and silver.

Ground water contamination varies both over time and area across the site. In 1983 , the highest concentration of sulfate was found in the western portion of the site (Figure 3.1). At present, the highest concentrations of sulfate (Figure 3.2) and chloride occur in the central portion of the site, near monitor well 135, the area that was once the site of evaporation ponds; to the west (in monitor wells 011 and 109) sulfate and chloride concentrations have decreased over time. However, in monitor wells 011 and 109, uranium and molybdenum concentrations have remained constant or have increased during the same period, indicating a lower-salinity contamination is replacing a higher-salinity contamination along the western portion of the site.

Comparing sulfate and chloride concentrations (1983 data) from well clusters in the contaminated area to the sulfate and chloride concentrations in the background well cluster demonstrates that contamination extends to at least $30 \mathrm{ft}(9 \mathrm{~m})$ below land surface within the unconfined aquifer. The vertical extent of contamination can be demonstrated by salinity that does not decrease with increasing depth. Data from two onsite wells screened between 54 and 68 $\mathrm{ft}(16.5$ to $20.1 \mathrm{~m})$ below land surface did not indicate contamination in 1983 . Therefore, available data indicate that contamination probably is limited to depths of less than 50 feet.

Chemical data from monitor wells on the south and east boundaries of the site (wells 130,132 , and 133) indicate contamination has not affected these crossgradient site boundaries. However, in the southeast corner of the site, monitor well 131 shows an increase in sulfate, sodium, chloride, uranium and 


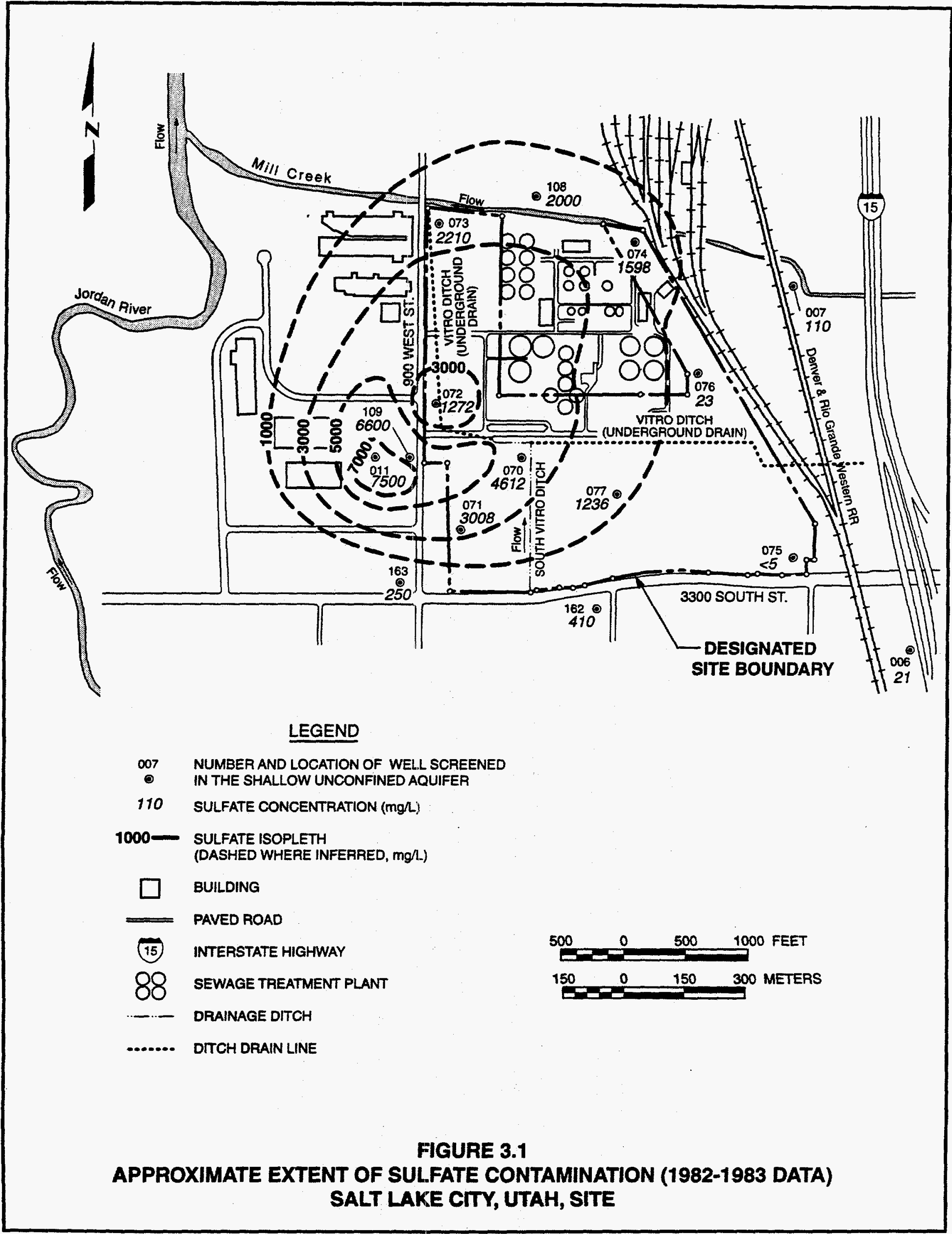




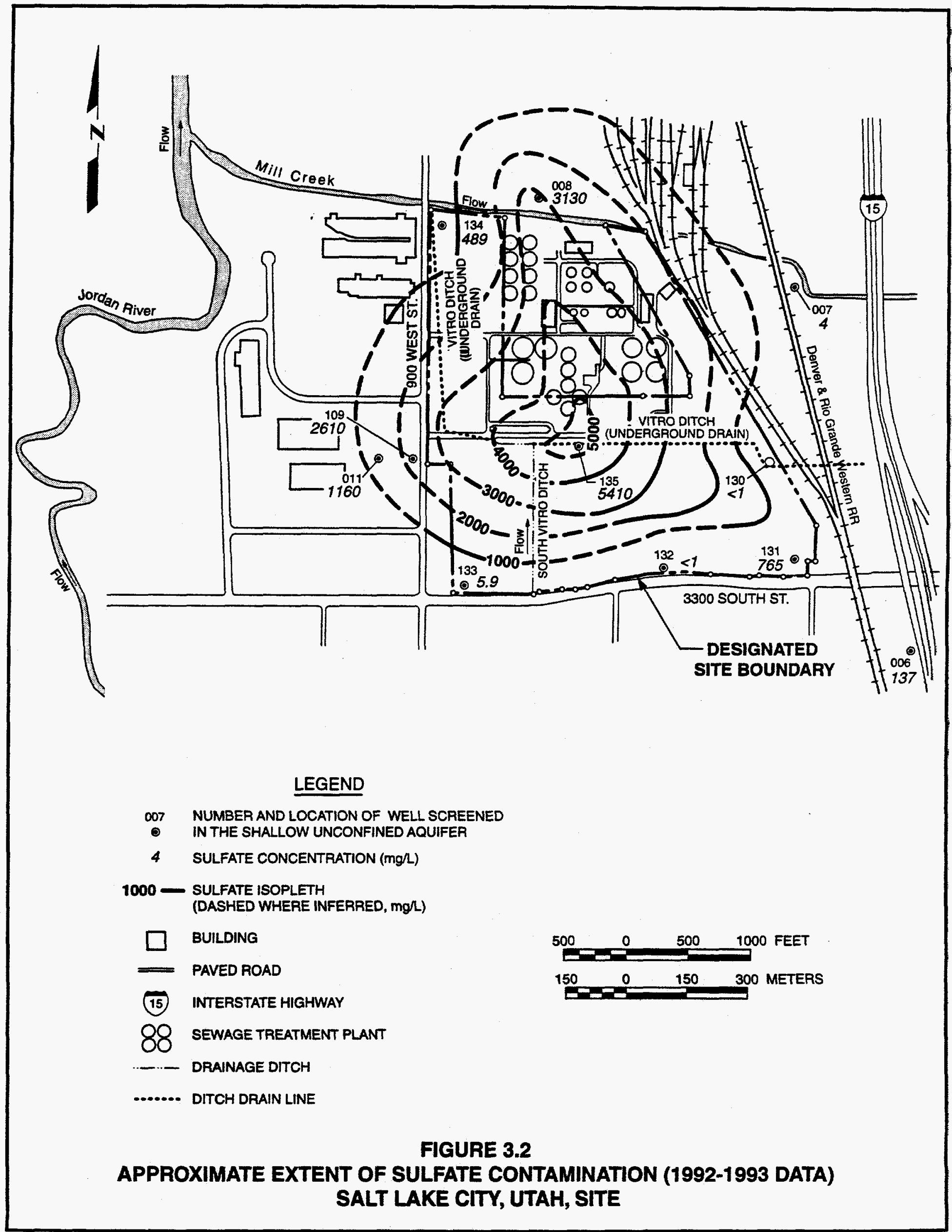


molybdenum. This well is near the old mill site, adjacent to the underpass of State Route 171 beneath the Denver \& Rio Grande Western Railroad. As discussed in Section 2.3.1, the underpass excavation created a lateral gradient reversal in the area (DOE, 1984b) and it appears that contaminated water is moving to the southeast, toward the underpass.

The extent of the contamination is unknown downgradient of the site, to the west and north. Contaminants have migrated beyond the existing monitor wells in these areas (wells 109,011,008, and 134). Extrapolating the existing chemical gradients could estimate the downgradient extent of the plume. However, there are too few existing wells for such an extrapolation to be meaningful.

\subsection{STATISTICAL ANALYSIS OF GROUND WATER QUALITY}

After determining the extent of contamination using a limited set of constituents indicative of contamination (chloride, sulfate, uranium, and molybdenum), water quality data collected between 1990 and 1993 were used to statistically identify the full suite of constituents elevated above background in contaminated portions of the unconfined aquifer (DOE, 1995a). Qualitative evaluation of water quality data from each plume monitor well showed similar constituent concentrations. Therefore, in the statistical evaluation, the 1990-1993 data from background well 007 were compared to the pooled 1990-1994 data for contaminated ground water from wells $008,011,109,131,134$, and 135 . For each constituent, a Mann-Whitney test was conducted at the 0.05 level of significance. A significant Mann-Whitney test result indicates the concentrations in the pooled data from all plume wells are, on average, higher than those in background.

Vanadium was screened out because most ( 70 percent or more) of the analyses were below detection and because all detected values were either within the range of laboratory error (that is, at the detection limit for the analysis) or associated with a systematic laboratory error in one round of sampling. Vanadium was detected in ground water in 14 instances; 10 of these detections occurred during a single sampling round and were near the limit of detection. Most of those 10 detections were not replicated by previous sampling rounds, and none was replicated by a subsequent sampling round. The remaining four vanadium detections during other sampling rounds were at the limit of detection for the analysis $10.01 \mathrm{mg} / \mathrm{L})$. Thus, these data probably reflect a systematic error in the laboratory analyses and do not represent toxicity concerns. In the future, ground water should be monitored for vanadium to verify it remains below background.

Table 3.4 summarizes the water quality data in the unconfined aquifer between 1990 and 1994. The following constituents were elevated statistically above background: ammonium, barium, calcium, chloride, fluoride, iron, magnesium, manganese, molybdenum, potassium, radium 226, silver, sodium, strontium, sulfate, and uranium. For these constituents, the concentrations observed in the 
most contaminated ground water wells are presented. However, these results are for filtered samples, and all the constituents may be reduced as a result of the filtration.

\subsection{CONTAMINANTS OF POTENTIAL CONCERN}

The results of analyses presented in Section 3.3 were used to compile a list of contaminants of potential concern for the assessment of risks to human health and the environment at the Salt Lake City site. The constituents listed in the first column of Table 3.5 are elevated above background levels at the 0.05 level of significance.

These constituents were screened for their potential to affect human health. The screening was based on the range of observed concentrations in filtered ground water samples between August 1990 and February 1994.

Some constituents were screened out because they are essential nutrients present at levels within nutritional ranges, even when added to expected dietary ranges (DOE, 1994b; DOE, 1995a). These constituents are calcium, iron, and potassium (Table 3.5 , column 2 ).

The final screening of the remaining contaminants was based on their relatively low toxicity and/or relatively high dietary intake by comparison to the values measured, so that levels at which they are observed at the site would not be associated with adverse health effects even when added to expected dietary intake (DOE, 1994; DOE, 1995a). Although silver levels in the plume (maximum observed concentration of $0.041 \mathrm{mg} / \mathrm{L}$ ) are above background, silver has been eliminated from the list of contaminants of potential concern because it would not be expected to result in adverse health effects in potentially exposed humans. Silver levels in contaminated ground water are well below the EPA health advisory levels of $0.2 \mathrm{mg} / \mathrm{L}$ for a 10-kilogram $[\mathrm{kg}]$ child following 10-day exposure duration and the level of $0.1 \mathrm{mg} / \mathrm{L}$ for a $70-\mathrm{kg}$ adult following lifetime exposure (EPA, 1993). Based on the screening, contaminants of potential concern to human health are chloride, fluoride, magnesium, molybdenum, sodium, sulfate, uranium, and radium-226 (Table 3.5 , column 3 ).

Uranium and radium-226 are the only radionuclides statistically above background levels in the unconfined aquifer (with a level of significance of less than 0.05). Because radionuclide toxicity, manifested as carcinogenicity, is a function of the total exposure dose from ionizing radiation, all of the longer-lived progeny of the uranium decay series are evaluated in Section 6.0.

These constituents form the basis of the human health risk assessment for ground water at the Vitro site. Because ecological impacts differ from effects on human health, the complete list of contaminants (Table 3.5 , column 1 ) is considered for ecological risk assessment in Section 7.0. 
Table 3.5 Contaminants of potential concern, Salt Lake City, Utah, site

\begin{tabular}{|c|c|c|c|}
\hline $\begin{array}{l}\text { Contaminant levels } \\
\text { exceed background }\end{array}$ & $\begin{array}{c}\text { Contaminant levels in } \\
\text { nutritional range }\end{array}$ & $\begin{array}{c}\text { Contaminant of low toxicity } \\
\text { compared to values } \\
\text { measured and/or high } \\
\text { dietary range }\end{array}$ & $\begin{array}{c}\text { Contaminant of } \\
\text { potential } \\
\text { concern }\end{array}$ \\
\hline $\begin{array}{l}\text { Ammonium } \\
\text { Barium } \\
\text { Calcium } \\
\text { Chloride } \\
\text { Fluoride } \\
\text { Iron } \\
\text { Magnesium } \\
\text { Manganese } \\
\text { Molybdenum } \\
\text { Potassium } \\
\text { Silver } \\
\text { Sodium } \\
\text { Strontium } \\
\text { Sulfate } \\
\text { Uranium } \\
\text { Radium-226 }\end{array}$ & $\begin{array}{l}\text { Calcium } \\
\text { Iron } \\
\text { Potassium }\end{array}$ & $\begin{array}{l}\text { Ammonium } \\
\text { Barium } \\
\text { Silver }^{b} \\
\text { Strontium }\end{array}$ & $\begin{array}{l}\text { Chloride } \\
\text { Fluoride } \\
\text { Magnesium } \\
\text { Manganese } \\
\text { Molybdenum } \\
\text { Sodium } \\
\text { Sulfate } \\
\text { Uranium } \\
\text { Radium-226 }\end{array}$ \\
\hline
\end{tabular}

a The screening process began with the first column. Constituents in the second and third columns were subtracted from the list of constituents in the first column. The remaining constituents form the list shown in the last column.

${ }^{b}$ Although silver levels in the plume (maximum observed concentration of $0.041 \mathrm{mg} / \mathrm{L}$ ) are above background, silver has been eliminated from the list of contaminants of potential concern because it would not be expected to result in adverse health effects in potentially exposed humans. Silver levels in contaminated ground water are well below the EPA health advisory levels of $0.2 \mathrm{mg} / \mathrm{L}$ for a 10-kilogram child following 10-day exposure duration and the level of 0.1 $\mathrm{mg} / \mathrm{L}$ for a $70-\mathrm{kg}$ adult following lifetime exposure (EPA, 1993). 
Contaminant mobility, uptake, and toxicity depend on the species of ions that exist in the aqueous environment. The type of ion species and complexes depend on the availability of various anions and cations for the formation of complex ions, and on $\mathrm{pH}$ and Eh conditions. Species of the contaminants of concern have been computed using the geochemical speciation code PHREEOE (Parkhurst et al., 1980). Table 3.6 summarizes the predominant species and their molar percentages. Modeling indicates the distribution of species and the valence state of metals do not notably change over the range of oxidationreduction potentials reported from ground water at the site $(100$ to -100 millivolts) (DOE, 1995a).

\section{Magnesium}

Modeling indicates magnesium concentrations are controlled by equilibrium with magnesite (magnesium carbonate) in both contaminated and background waters, as a function of alkalinity and the partial pressures of carbon dioxide. In soils, soil bacteria usually hold carbon dioxide partial pressures at near-constant values. In 1983, partial pressures of carbon dioxide were high lat or greater than 1 atmospheric pressure) in response to neutralization of the tailings solutions by carbonates. With time, the partial pressure of carbon dioxide in contaminated ground water has decreased to near background levels 10.016 atmospheres). The decrease was probably accompanied by the precipitation of magnesite, which resulted in decreased alkalinity and decreased magnesium concentrations. Because most carbon dioxide degassing has already occurred, further decreases in magnesium and alkalinity will be due to dilution.

\section{Chloride}

Chloride concentrations are about 45 times those of background. Chloride forms insoluble salts at high salinities (above $180,000 \mathrm{mg} / \mathrm{L}$ chloride concentrations). Therefore, observed concentrations are too low to be affected by precipitation. In contrast, chloride concentrations are too great to be affected by adsorption. Therefore, decreases in chloride concentrations within the contaminated ground water will be due to dilution.

\section{Eluoride}

Fluoride concentrations in contaminated ground water are about 3 times those of background. Fluoride forms fluorite (calcium fluoride), a relatively insoluble mineral. However, both contaminated and background water are below fluorite saturation by a factor of 10 . Thus, fluoride will decrease from slightly higher than background $(2.4 \mathrm{mg} / \mathrm{L})$ to background levels $(0.8 \mathrm{mg} / \mathrm{L})$ in response to dilution. 
Table 3.6 Predominant ionic species of the constituents of potential concern

\begin{tabular}{|c|c|c|c|c|}
\hline Constituent & Common name & $\begin{array}{l}\text { Dominant } \\
\text { species }\end{array}$ & Valence & $\begin{array}{c}\text { Molar } \\
\text { percent }\end{array}$ \\
\hline Ammonium & & Not determined & & \\
\hline Chloride & Chloride & $\mathrm{Cl}^{\circ}$ & $\mathrm{Cl}(-1)$ & 100 \\
\hline Fluoride & $\begin{array}{l}\text { Fluoride } \\
\text { Magnesium fluoride }\end{array}$ & $\begin{array}{l}\mathrm{F}^{-} \\
\mathrm{MgF}^{+}\end{array}$ & $\begin{array}{l}F(-1) \\
F(-1)\end{array}$ & $\begin{array}{l}69 \\
30\end{array}$ \\
\hline Magnesium & $\begin{array}{l}\text { Magnesium } \\
\text { Magnesium sulfate } \\
\text { Magnesium bicarbonate }\end{array}$ & $\begin{array}{l}\mathrm{Mg}^{2+} \\
\mathrm{MgSO}_{4} \text { aq } \\
\mathrm{MgHCO}_{3}\end{array}$ & $\begin{array}{l}M g(I I) \\
M g(I I) \\
M g(I I)\end{array}$ & $\begin{array}{r}63 \\
32 \\
5\end{array}$ \\
\hline Manganese & $\begin{array}{l}\text { Manganese } \\
\text { Manganese sulfate }\end{array}$ & $\begin{array}{l}\mathrm{Mn}^{2+} \\
\mathrm{MnSO}_{4} \text { aq }\end{array}$ & $\begin{array}{l}\text { Mn(II) } \\
\text { Mn(II) }\end{array}$ & $\begin{array}{l}63 \\
26\end{array}$ \\
\hline Molybdenum & Molybdate & $\mathrm{MoO}_{4}{ }^{2-}$ & Mo(VI) & 100 \\
\hline Sodium & $\begin{array}{l}\text { Sodium } \\
\text { Sodium sulfate }\end{array}$ & $\begin{array}{l}\mathrm{Na}^{+} \\
\mathrm{NaSO}_{4}^{-}\end{array}$ & $\begin{array}{l}\mathrm{Na}(I) \\
\mathrm{Na}(\mathrm{I})\end{array}$ & $\begin{array}{r}95 \\
4\end{array}$ \\
\hline Sulfate & $\begin{array}{l}\text { Sulfate } \\
\text { Magnesium sulfate } \\
\text { Sodium sulfate }\end{array}$ & $\begin{array}{l}\mathrm{SO}_{4}{ }^{2-} \\
\mathrm{MgSO}_{4} \mathrm{aq} \\
\mathrm{NaSO}_{4}^{-}\end{array}$ & $\begin{array}{l}\text { S(VI) } \\
\text { S(VI) } \\
\text { S(VI) }\end{array}$ & $\begin{array}{r}66 \\
22 \\
9\end{array}$ \\
\hline Uranium & Uranyl tricarbonate & $\mathrm{UO}_{2}\left(\mathrm{CO}_{3}\right)_{3}^{4-}$ & $U(V I)$ & 97 \\
\hline Radium-226 & & Not determined & & \\
\hline
\end{tabular}




\section{Manganese}

Manganese concentrations are up to about 16 times those of background. Like iron, manganese is most soluble under acidic or reducing conditions although manganese can persist at greater concentrations than iron in oxidizing, nearneutral $\mathrm{pH}$ ground water. None of the ground water at the site is saturated with manganese oxides or manganese carbonate (rhodochrosite). Therefore, the major decrease in concentration will be due to dilution, perhaps accompanied by coprecipitation with iron oxides and sorption.

\section{Molybdenum}

Molybdenum concentrations range up to about 94 times that of background. Molybdenum occurs in the contaminated ground water as molybdate $\left(\mathrm{MoO}_{4}{ }^{2-}\right)$, a negatively charged ion. As with most negatively charged ions, molybdenum sorption is most effective under acidic conditions ( $\mathrm{pH}$ in the 3 to 4 range). Thus sorption of molybdenum in the contaminated ground water will be less important than dilution as a mechanism for decreasing concentrations.

\section{Sodium}

Sodium concentrations in contaminated ground water are up to about 20 times those of background. Sodium forms very soluble bicarbonate, chloride and sulfate salts; therefore, those salts will not precipitate. A likely mechanism for its removal is cation exchange for magnesium and calcium within clay minerals, but not enough information is available to evaluate this mechanism at the site. Dilution will probably play the greatest role in decreasing its concentrations.

\section{Sulfate}

Sulfate concentrations vary across the site, from 249 to $5560 \mathrm{mg} / \mathrm{L}$ in contaminated water (Figure 3.2). Most of the contaminated water is undersaturated with respect to gypsum, the phase most likely to control the sulfate concentration in this ground water. Therefore, the observed real decreases in sulfate, which are matched by decreases in chloride, are due to dilution of the tailings solutions by natural waters. This dilution may have occurred in the well bore or during the initial migration of the tailings solutions into the aquifer, either by mixing with diluted surface water before infiltration (as would be the case along the former Vitro Ditch) or by mixing with dilute ground water during infiltration. Further decreases in sulfate concentrations will occur by dilution and dispersion as the contaminated ground water migrates.

\section{Uranium}

Uranium concentrations in contaminated ground water are about 30 times as great as those in background. Uranium occurs in the hexavalent $(+6)$ state in the site ground water as a uranyl carbonate complex $\left(\mathrm{UO}_{2}\left(\mathrm{CO}_{3}\right)_{3}{ }^{4-}\right)$. Because 
this complex is mobile in neutral-to-alkaline ground water, dilution will be the primary control on uranium concentrations.

\section{Radium-226}

Radium-226 concentrations in the contaminated ground water range from 0.1 to $1.3 \mathrm{pCi} / \mathrm{L}$, with the maximum value about 3 times the maximum observed background value of $0.5 \mathrm{pCi} / \mathrm{L}$. In ground water, radium coprecipitates with sulfates, such as gypsum. However, because most water at the site is now below gypsum saturation, further gypsum precipitation will not occur. Therefore, dilution will have the greatest effect on decreasing radium concentrations in the contaminated ground water.

\subsection{SURFACE WATER AND SEDIMENT SAMPLING}

Both South Vitro Ditch and Vitro Ditch were identified as having radium-226 or thorium-230 contaminated sediments prior to surface remediation. These contaminated sediments were removed during surface remediation (DOE, 1995b) and thus, contaminated sediments are no longer a potential source for surface water contamination. However, there is a current potential for contaminated ground water to enter the ditches and for those contaminants to accumulate in sediments. Also, there is the potential for contaminated ground water to discharge to Mill Creek along the north edge of the site or to enter Mill Creek from Vitro Ditch. This contaminated surface water could then enter the Jordan River. For these reasons, samples of surface water and sediment were collected and analyzed for site-related contamination in 1993.

\section{Jordan River}

Surface water and sediment samples were collected at four locations in December 1993 (locations 183, 184, 188, and 185) (Figure 2.2 and Table 3.7). Results of these screening analyses of surface water samples indicate no evidence for site-related contamination of the Jordan River downstream of the site. Concentrations of constituents downstream of the site are generally less than or the same as those observed upstream of the site. The decrease in concentrations of several site-related contaminants downstream of the site, such as uranium and sulfate, is due to dilution by better quality water from Mill Creek.

Sediment samples were collected from the same locations in the Jordan River. The upriver location in the Jordan River showed the highest values for virtually all constituents sampled in December 1993, suggesting that there is no siterelated contamination in the river sediments (Table 3.8 ). 
Table 3.7 Surface water quality data of Mill Creek and Jordan River, Salt Lake City, Utah, site

\begin{tabular}{|c|c|c|c|c|c|c|c|}
\hline \multirow[b]{3}{*}{ Contaminant } & \multicolumn{3}{|c|}{ Mill Creek } & \multicolumn{4}{|c|}{ Jordan River } \\
\hline & \multicolumn{2}{|c|}{ Upstream } & \multirow{2}{*}{$\frac{\text { Downstream }}{182}$} & \multicolumn{3}{|c|}{ Upstream } & \multirow{2}{*}{$\frac{\text { Downstream }}{183}$} \\
\hline & 180 & 181 & & 184 & 188 & 185 & \\
\hline Calcium & 104 & 113 & 85 & $\overline{141}$ & 139 & 135 & 86 \\
\hline Chloride & 66 & 67 & 197 & 288 & 296 & 278 & 200 \\
\hline Magnesium & 36 & 39 & 35 & 64 & 63 & 60 & 35 \\
\hline Molybdenum & $<0.01$ & $<0.01$ & $<0.01$ & 0.01 & 0.01 & 0.01 & $<0.01$ \\
\hline Selenium & $<0.005$ & $<0.005$ & $<0.005$ & $<0.005$ & $<0.005$ & $<0.005$ & $<0.005$ \\
\hline Silver & $<0.01$ & $<0.01$ & $<0.01$ & $<0.01$ & $<0.01$ & $<0.01$ & $<0.01$ \\
\hline Strontium & 1.01 & 1.08 & 0.78 & 1.28 & 1.29 & 1.25 & 0.79 \\
\hline Sulfate & 173 & 173 & 141 & 340 & 349 & 339 & 147 \\
\hline Uranium & 0.002 & 0.002 & 0.004 & 0.015 & 0.015 & 0.015 & 0.005 \\
\hline
\end{tabular}

Notes:

1. Unfiltered water samples collected December 6, 1993.

2. All parameters reported in milligrams per liter.

3. Sampling locations $180,181,184,185$, and 188 are upstream of the site. Sampling locations 182 and 183 are downstream.

Table 3.8 Summary of Mill Creek and Jordan River sediment chemistry data, December 1993, Salt Lake City, Utah, site

\begin{tabular}{|c|c|c|c|c|c|c|c|}
\hline \multirow[b]{3}{*}{ Parameter } & \multicolumn{3}{|c|}{ Mill Creek } & \multicolumn{4}{|c|}{ Jordan River } \\
\hline & \multicolumn{2}{|c|}{ Upstream } & \multirow{2}{*}{$\frac{\text { Downstream }}{182}$} & \multicolumn{3}{|c|}{ Upstream } & \multirow{2}{*}{$\frac{\text { Downstream }}{183}$} \\
\hline & 180 & 181 & & 184 & 188 & 185 & \\
\hline Calcium & 76,100 & 64,500 & 8,810 & 17,600 & 55,500 & 72,000 & 18,400 \\
\hline Chloride & 110 & 807 & 165 & 57 & 220 & 304 & 117 \\
\hline Magnesium & 11,000 & 10,900 & 18,200 & 4,140 & 11,500 & 12,500 & 3,670 \\
\hline Molybdenum & $<4.6$ & $<4.2$ & $<4.1$ & $<2.8$ & $<4.8$ & $<6.4$ & $<2.7$ \\
\hline Selenium & $<2.3$ & $<2.1$ & $<2.1$ & $<1.4$ & $<2.4$ & $<3.2$ & $<1.3$ \\
\hline Silver & $<4.6$ & $<4.2$ & $<4.2$ & $<2.8$ & $<4.8$ & $<6.4$ & $<2.7$ \\
\hline Sodium & 908 & 857 & 1,240 & 575 & 1,600 & 1,620 & 519 \\
\hline Strontium & 190 & 153 & 82.6 & 47.5 & 197 & 272 & 60.1 \\
\hline Sulfate & 60 & 184 & 67 & $<14$ & 116 & 91 & 150 \\
\hline Uranium & 1.3 & 1.4 & 1.2 & 0.65 & 2.1 & 2.5 & 0.74 \\
\hline
\end{tabular}

Notes:

1. Concentrations in milligrams per kilogram.

2. < indicates less than the given method detection limit. 


\section{Mill Creek}

Surface water and sediment samples were collected at three locations in December 1993 (180, 181, and 182) (Figure 2.2). A sample from Mill Creek taken downstream of its confluence with South Vitro Ditch (sampling location 182 ) indicates water quality in Mill Creek changes below the confluence. Some of those changes, however, such as increases in sodium and chloride and decreases in calcium, sulfate, and strontium, probably are attributable to the treated effluent discharged by the CVWRF. Future sampling of the CVWRF effluent will be considered to address this contamination. There is the potential for uranium in contaminated ground water to enter the sewage treatment system via check valves in large clarifier tanks. Thus, the slight increase in uranium (from 0.002 to $0.004 \mathrm{mg} / \mathrm{L}$ ) downstream of the South Vitro Ditch may be from the treated effluent, from contaminated ground water entering Mill Creek from South Vitro Ditch, or from direct discharge of contaminated ground water to Mill Creek. However, Mill Creek samples have uranium concentrations less than those in the Jordan River upstream of the site (up to $0.015 \mathrm{mg} / \mathrm{L}$ ).

The screening analysis of sediment samples collected in December 1993 from Mill Creek indicates that constituent concentrations do not increase at the downstream location (sample site 182), suggesting that there is no site-related contamination of the creek sediments (Table 3.9). However, a more thorough sampling of site-related contaminant trace metals would be required to rule out the possibility of site-related impacts on sediments in Mill Creek.

Table 3.9 Summary of Vitro Ditch and South Vitro Ditch sediment chemistry data, December 1993, Salt Lake City, Utah, site

\begin{tabular}{|c|c|c|}
\hline Parameter & $\begin{array}{c}\text { South end } \\
186\end{array}$ & $\begin{array}{c}\text { North end } \\
187\end{array}$ \\
\hline $\begin{array}{l}\text { Calcium } \\
\text { Chloride } \\
\text { Magnesium } \\
\text { Molybdenum } \\
\text { Selenium } \\
\text { Silver } \\
\text { Sodium } \\
\text { Strontium } \\
\text { Sulfate } \\
\text { Uranium }\end{array}$ & $\begin{array}{c}69,800 \\
41 \\
3,710 \\
6 \\
<1.4 \\
<2.7 \\
718 \\
79 \\
77 \\
3.9\end{array}$ & $\begin{array}{c}81,700 \\
130 \\
16,500 \\
236 \\
<1.4 \\
<6.4 \\
1,600 \\
43 \\
99 \\
4.8\end{array}$ \\
\hline
\end{tabular}

Notes:

1. Concentrations in milligrams per kilogram.

2 . < indicates less than the given method detection limit. 


\section{Vitro Ditch and South Vitro Ditch}

Because current surface water quality data are not available for Vitro Ditch and South Vitro Ditch, the present impact of the processing site on the water quality in South Vitro Ditch cannot be demonstrated or ruled out.

No background data are available for sediments in South Vitro Ditch. However, for the purposes of a screening analysis, constituents have been compared to average concentrations of elements in soils. These comparisons indicate that sediments in South Vitro Ditch collected in December 1993 had a high concentration of molybdenum $(236 \mathrm{mg} / \mathrm{kg}$ ) at the north end (sample site 187 in Figure 2.2). The molybdenum level at location 187 was much higher than the average for soils in the western United States $(6 \mathrm{mg} / \mathrm{kg}$ ) (Jarrell et al., 1980) and the suggested maximum acceptable concentrations of $37 \mathrm{mg} / \mathrm{kg}$ for soils at UMTRA Project sites (JEG, 1986). Lower concentrations of molybdenum $(6.6 \mathrm{mg} / \mathrm{kg}$ ) occur at the south end of South Vitro Ditch (sample site 186).

\section{Summary}

A screening analysis of surface water and sediment indicates that there are no impacts of site-related contamination to the Jordan River. Surface water in Mill Creek may be receiving a small amount of uranium from the site. Measured concentrations of uranium increased from 0.002 to $0.004 \mathrm{mg} / \mathrm{L}$ downstream of the site. Sediments in Mill Creek do not appear to be impacted; however, this conclusion is based on limited information. Because there are no current surface water data for Vitro Ditch and South Vitro Ditch, site-related impacts of potential ground water discharge cannot be evaluated. However, elevated concentrations of molybdenum in sediments from South Vitro Ditch suggest that surface water is being impacted by ground water discharge from the site. 


\subsection{EXPOSURE ASSESSMENT}

Exposure can occur only if there are both a source of contamination and a mechanism of transport to a receptor population or individual. This section discusses the environmental interactions of affected media, exposure pathways, and potential receptors scenarios (Figure 4.1). This section also quantifies the possible exposures that could be incurred by future residents and others who could use contaminated ground water at the Vitro site. Livestock and other environmental receptors exposures and resulting toxicities are evaluated in Section 7.0.

\subsection{POTENTIALLY EXPOSED POPULATION}

As discussed in Sections 2.4 and 3.2, contaminants related to former mill operations are limited in extent to ground water in the shallow unconfined aquifer. Ground water contaminated by uranium processing at the Salt Lake City site is not currently used by area residents. As shown in Figure 2.5, ground water is not withdrawn from the unconfined aquifer within a $2-\mathrm{mi}(3-\mathrm{km})$ radius of the site. Water from the shallow unconfined aquifer is of poor quality (USGS, 1984; DNRS, 1971). Therefore, area residents use water supplied by a municipal water system, which obtains water from the deeper confined aquifer. One proposed municipal well completed in the deep, confined aquifer is on the former Vitro site. This risk assessment finds no contamination in the municipal well water collected during testing of the well (Section 3.0).

Although plans for future land use do not specify residential developments at the site, such land uses cannot be precluded. Therefore it is assumed that in the future, a domestic well could be installed in the most contaminated portion of the aquifer at the site, creating the potential for exposure through drinking, bathing, livestock watering, or irrigation. However, the likelihood of residential development and the use of poor quality ground water from the unconfined aquifer at the site in the future is considered low.

Although plans for future land use do not specify residential developments at the site, such land uses cannot be precluded. Therefore, such development is considered for this risk assessment.

The future residential scenario evaluates domestic ground water use consistent with current water uses by the population in the region.

The potentially exposed population includes residents of the following age groups: infants (birth to 1 year old); children (1 to 10 years old), and adults (11 to 65 years old). These age groups were selected for the following reasons.

- Survey data for population variables such as age, weight, and daily water intake are available for these age groups. 


$\begin{array}{ccc}\text { HISTORICAL } & \text { RELEASE } & \text { ENVIRONMENTAL } \\ \text { SOURCE } & \text { MECHANISM } & \begin{array}{c}\text { TRANSPORT } \\ \text { MEDIUM }\end{array}\end{array}$

\begin{tabular}{|c|c|c|c|}
\hline $\begin{array}{c}\text { POSSIBLE } \\
\text { EXPOSURE } \\
\text { ROUTES }\end{array}$ & \multicolumn{3}{|c|}{ POTENTIAL RECEPTORS } \\
\cline { 2 - 3 } & $\begin{array}{c}\text { FUTURE } \\
\text { RESIDENT }\end{array}$ & $\begin{array}{c}\text { TERAESTAIAL } \\
\text { PLANTS AND } \\
\text { ANIMALS/ } \\
\text { LIVESTOCK }\end{array}$ & $\begin{array}{c}\text { AQUATIC } \\
\text { PLANTS AND } \\
\text { ANIMALS }\end{array}$ \\
\hline
\end{tabular}

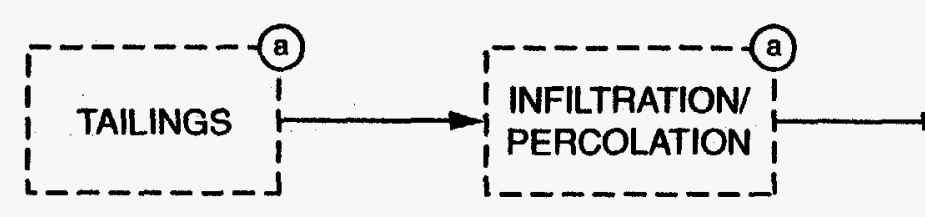

$\stackrel{\leftrightarrow}{\sim}$

LEGEND

THE SHALLOW UNCONFINED AQUIFER. EXPOSURE

(b) POSSIBLE THROUGH DOMESTIC, LIVESTOCK, OR

IRRIGATION WELLS, GROUND WATER-FED POND,

(C) THE MILL CREEK AND SOUTH VITRO DITCH.

EVALUATED RECEPTOR SCENARIO. REFER TO THE TEXT

$X$ FOR DISCUSSION OF WHICH SCENARIOS HAVE

THE POTENTIAL TO AFFECT HUMAN HEALTH OR THE ENVIRONMENT.

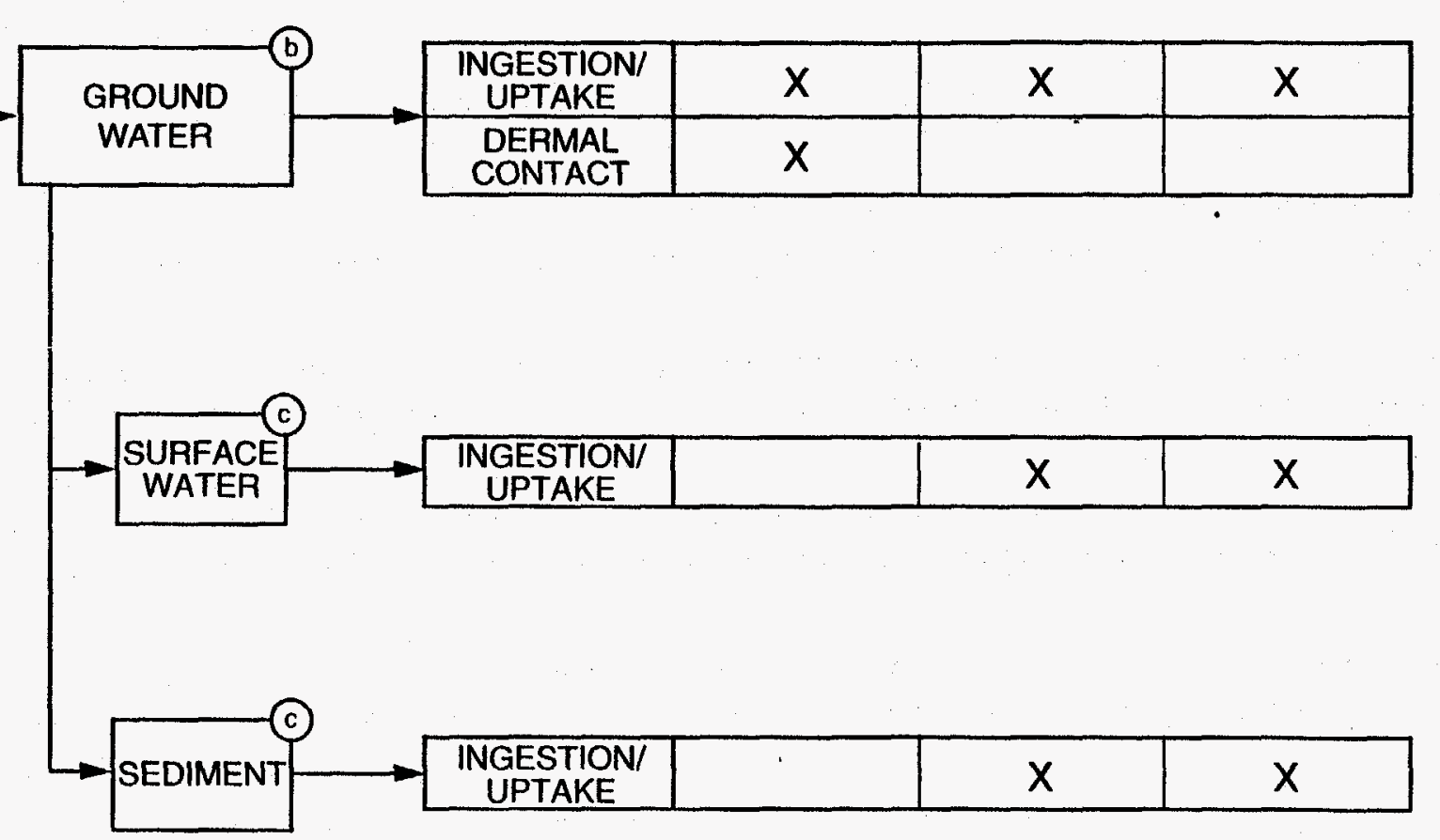

FIGURE 4.1

CONCEPTUAL MODEL

SALT LAKE CITY, UTAH, SITE 
- Toxicological variables are similar within these age groups, including responsiveness of sensitive subgroups (infants, children, and adults) to the contaminants of potential concern, toxicant intake-to-body-weight ratios, and toxicokinetics (a study of the time course of absorption, distribution, metabolism, and excretion of a contaminant in an individual's body).

Some individuals and/or subpopulations could be more vulnerable to possible exposures than the general population. These sensitive subpopulations could include infants, children, the elderly, or people with preexisting illness such as diabetes or kidney insufficiency with the absence of diabetes.

\subsection{EXPOSURE PATHWAYS}

An exposure pathway describes the course a contaminant takes from the source to the exposed individual or population. For an exposure pathway to be complete, there must be a source of contamination, a point of contact with a population or individual, and a route of exposure (e.g., water ingestion). Because the tailings piles and soils contaminated from uranium milling operations at the site were removed and relocated to a disposal cell, soil or air exposure pathways (such as incidental soil ingestion, dermal contact with soil, or inhalation of particulates) are not considered.

This assessment evaluates ground water exposure pathways. Figures 4.1 and 4.2 provide a conceptual model of the possible future ground water exposure pathways that are believed to lead to the greatest exposure possible at the former Vitro site. Pathways that are not considered in this model, but that could possibly be completed, include exposure to soil contaminated via irrigation (for example, inhalation of fugitive dust and incidental soil ingestion). Preliminary calculations demonstrate that the sum of these pathways typically contributes much less to the total exposure dose than exposure from drinking water ingestion and would not be associated with health problems (DOE, 1995a). Under some future land uses or construction activities, these pathways could constitute a notable exposure. Upon determination of a specific land use or construction activity, these pathways may therefore require additional evaluation.

Although it is unlikely that the ground water in the unconfined aquifer at the site will be used in the future for drinking purposes because of its naturally poor quality, slow yield to wells and the availability of good quality water from the municipal water supply system, this risk assessment evaluates a hypothetical future use of the ground water from the shallow unconfined aquifer.

Ground water in the region is used primarily for household purposes such as drinking, cooking, and bathing. Other uses typical of the region that could lead to human exposure are irrigation and livestock watering. 


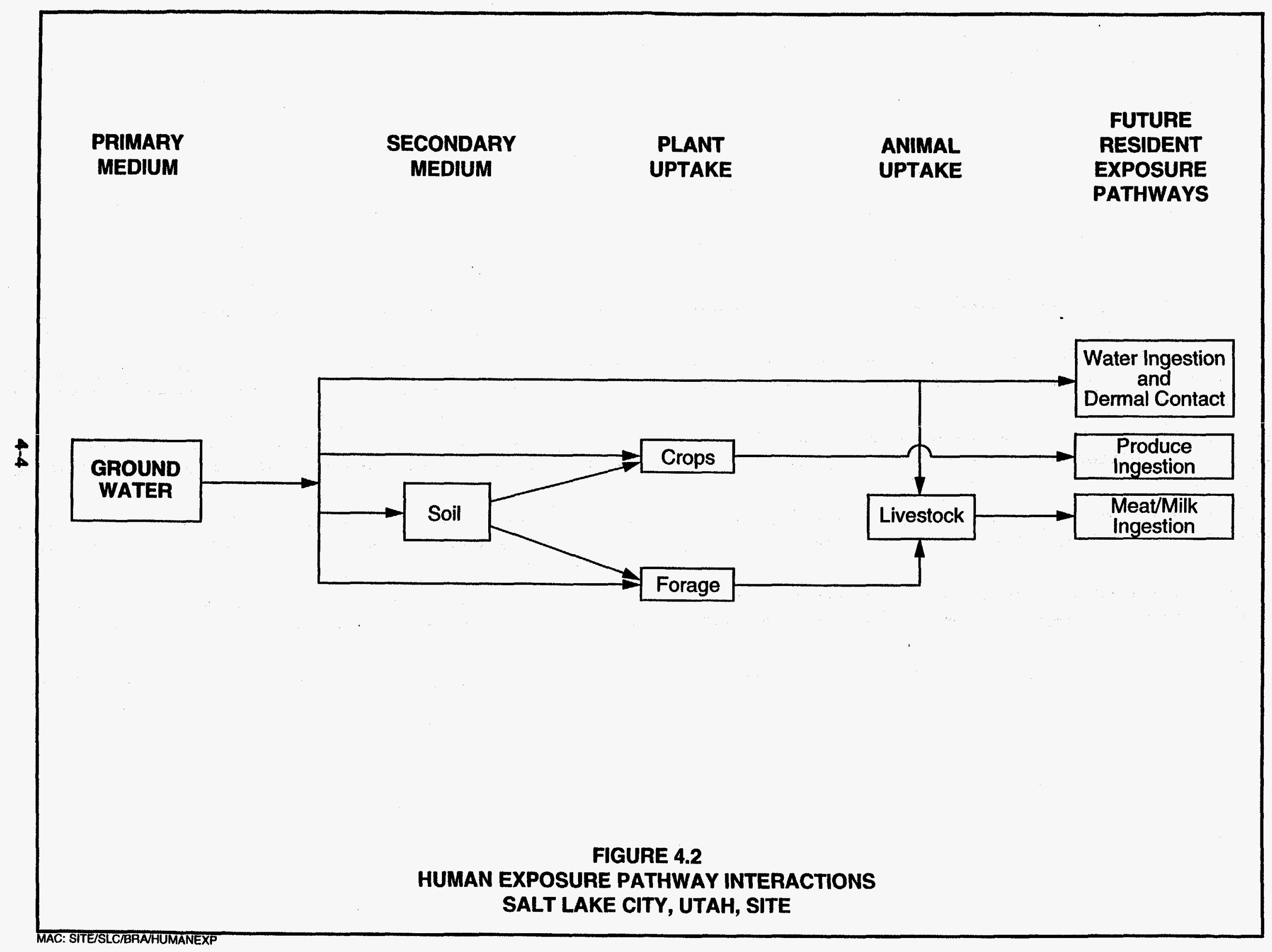




\subsubsection{Drinking water ingestion}

Drinking water ingestion generally is the dominant exposure route for ground water contaminated with metals and other nonvolatile compounds (DOE, 1994b). In this evaluation, drinking water consumption includes water ingested by drinking and consuming food prepared with water (e.g., reconstituted juices, soup, rice, and beans). Because drinking water ingestion is the dominant pathway, it is evaluated probabilistically in Section 4.4.

\subsubsection{Dermal absorntion}

Dermal absorption is the process by which chemicals coming into contact with the skin become absorbed into the blood vessels near the surface of the skin. Although some compounds are absorbed easily in this manner, metals are poorly absorbed through intact skin (EPA, 1992).

To determine whether dermal absorption route is likely to be an important route of exposure, a screening level calculation was performed to learn the relative contribution of dermal absorption to exposure dose from the drinking water ingestion route for the contaminants of potential concern (DOE, 1995a). Because chemical-specific absorption factors are not available for these contaminants, they are assumed to absorb across intact skin at the same rate as water (EPA, 1992). This assumption probably overestimates the potential exposure contribution from dermal absorption.

Although the dermal dose is an absorbed dose and only a percentage of the ingested dose will be absorbed, the very low ( 0.2 percent) relative contribution of dermal absorption is assumed to be insignificant compared to drinking water ingestion exposure route (DOE, 1995a). Because the assumptions used to estimate the dermal absorption dose are believed to overestimate exposure (metals are assumed to be absorbed like water), and because the dose is less than a 1 percent incremental contribution to the exposure from drinking water ingestion and would not be associated with health problems, this pathway is not further evaluated in this risk assessment.

\subsubsection{Ingestion of ground water-irrigated produce}

Contaminants in ground water could be taken up by plants either through roots in soil saturated with contaminated ground water or from irrigation water obtained by a well in the contaminated ground water. These plants could be eaten by humans or could enter the food chain and subsequently be consumed in the form of meat or milk. The amount this exposure route contributes could be substantial if the contaminants concentrate in plants. However, there are currently not enough data to evaluate this potential contribution based on literature values. The UMTRA Ground Water Project is currently studying contaminant uptake by irrigated vegetables and grasses. When these data become available, this pathway can be evaluated for this site; any results will be included in the site environmental assessment or environmental impact 
statement. If applicable, these data will also be considered in the development of a ground water compliance strategy for the site.

An evaluation of potential damage to plants from contaminated ground water is presented in Section 7.0.

\subsubsection{Ingestion of meat or milk from livestock drinking ground water}

These pathways were eliminated from further consideration because the sulfate concentrations are so high that livestock could not chronically drink the water. If the livestock cannot consume the water, contaminants cannot bioaccumulate or transfer to meat tissue or milk. Evaluation of the toxicity of contaminants of potential concern to livestock is presented in Section 7.0.

\subsection{EXPOSURE CONCENTRATIONS}

For a contaminant in ground water, exposure concentration is the concentration contacted by an individual over the period of exposure being considered. In this evaluation, the contaminant concentrations (and therefore exposures) are assumed to be in a steady state, even though actual exposure concentrations are expected to fluctuate but eventually decrease with time because the site has been remediated. Nonetheless, they are reasonable estimates for chronic exposure soon after surface remediation. Chronic exposure for noncarcinogens is considered any period longer than 7 years. For carcinogens, a lifetime exposure over 30 years is considered.

Exposure concentrations are evaluated as a probability of occurrence based on ground water data collected from monitor well 135. This well is closest to the former tailings location and raffinate ponds and has consistently shown the highest contamination levels in the past 3 years of monitoring. Three exceptions to this rule occurred.

- Fluoride, manganese, and uranium levels were higher in well 109 than in well 135; samples from well 109 were analyzed for fluoride, manganese, and uranium toxicities.

- Molybdenum concentrations were consistently higher in well 131 than in well 135; therefore, molybdenum toxicity was analyzed based on levels observed in well 131.

- The maximum observed concentration measured in ground water from combined downgradient wells 008, 011, 109, 131, and 135 was used for radium-226 and other longer-lived progeny of the uranium decay series. Carcinogenic effects associated with exposure to radium-226, lead-210, polonium-210, and thorium-230 are evaluated in Section 6.0.

The probability distribution selected for a contaminant had approximately the same mean, median, standard deviation, and shape as were observed in the 
actual water quality data (DOE, 1995a). The upper tails of the distributions were truncated at the 99th percentile. This truncation is conservative, since for every contaminant, the highest concentration in the distribution was higher than the maximum observed concentration in the data base. The software package @RISK (Palisade Corporation, 1992) was used to generate the probability curves for the contaminants of potential concern. The results are shown in Figures 4.3 through 4.10.

\subsection{ESTIMATION OF INTAKE}

Individuals within this hypothetical population are expected to vary in their water consumption habits, stable body weight, and length of time they reside in the potential contamination zone. Consequently, health risks associated with ground water consumption will also vary in this population. To adequately describe the range of potential risks to a future population, naturally occurring variabilities in daily water intake, body weight, and residency time were incorporated in this assessment through probability distributions selected from published public health and census documents for the United States. All distributions were truncated at the upper and lower 0.01 percentile (DOE, 1995a). Values disallowed through this truncation have a probability of less than 1 in 10,000 of occurring within this hypothetical population.

The potential toxicity of noncarcinogenic contaminants in drinking water depends primarily on long-term or chronic (i.e., at least 7 years) average daily consumption of the contaminant per kilogram of body weight (measured in milligrams per kilogram per day [mg/ $/ \mathrm{kg}$-day]). For these noncarcinogenic contaminants, chronic daily intake is calculated as follows:

(1) Intake (mg/kg-day) = Concentration $(\mathrm{mg} / \mathrm{L}) \times$ ingestion rate (L/day) $\times \mathrm{EF}$ (days/year) $\times \mathrm{ED}$ (yrs) Body weight $(\mathrm{kg}) \mathrm{x}$ averaging time ( 365 days/year $x$ ED [yrs])

Radionuclide carcinogenicity increases with total intake over time, compared to the average daily intake for noncarcinogens. Also, the body weight factor is relatively insignificant in determining risk from exposure. Intake of a radioactive carcinogenic substance (measured in picocuries) is therefore quantified as total exposure to radioactivity throughout the residency period of an individual:

(2) Intake (pCi/lifetime $\rangle=$ Concentration $x$ Ingestion rate $\times$ Exposure duration $x$ Exposure frequency (pCi/L) (L/day) (years) (days/year)

\section{Average daily intake (L/day)}

Lognormal probability distributions were used to describe variations in average daily tap water intake among members of the hypothetical population (Roseberry and Burmaster, 1992). These distributions were developed from data collected during the 1977-1978 National Food Consumption Survey conducted by the U.S. Department of Agriculture. During the survey, total tap water consumption 

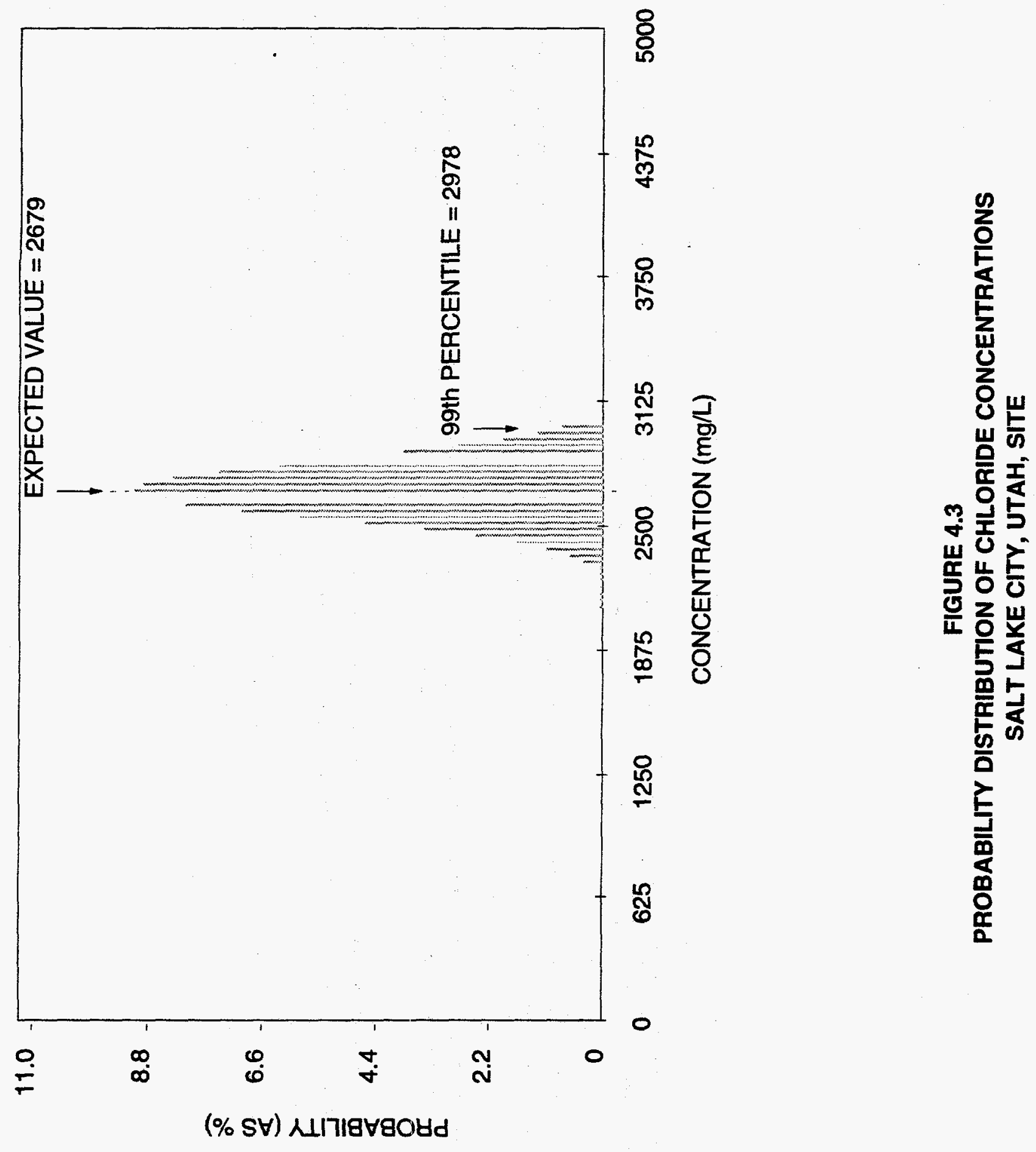


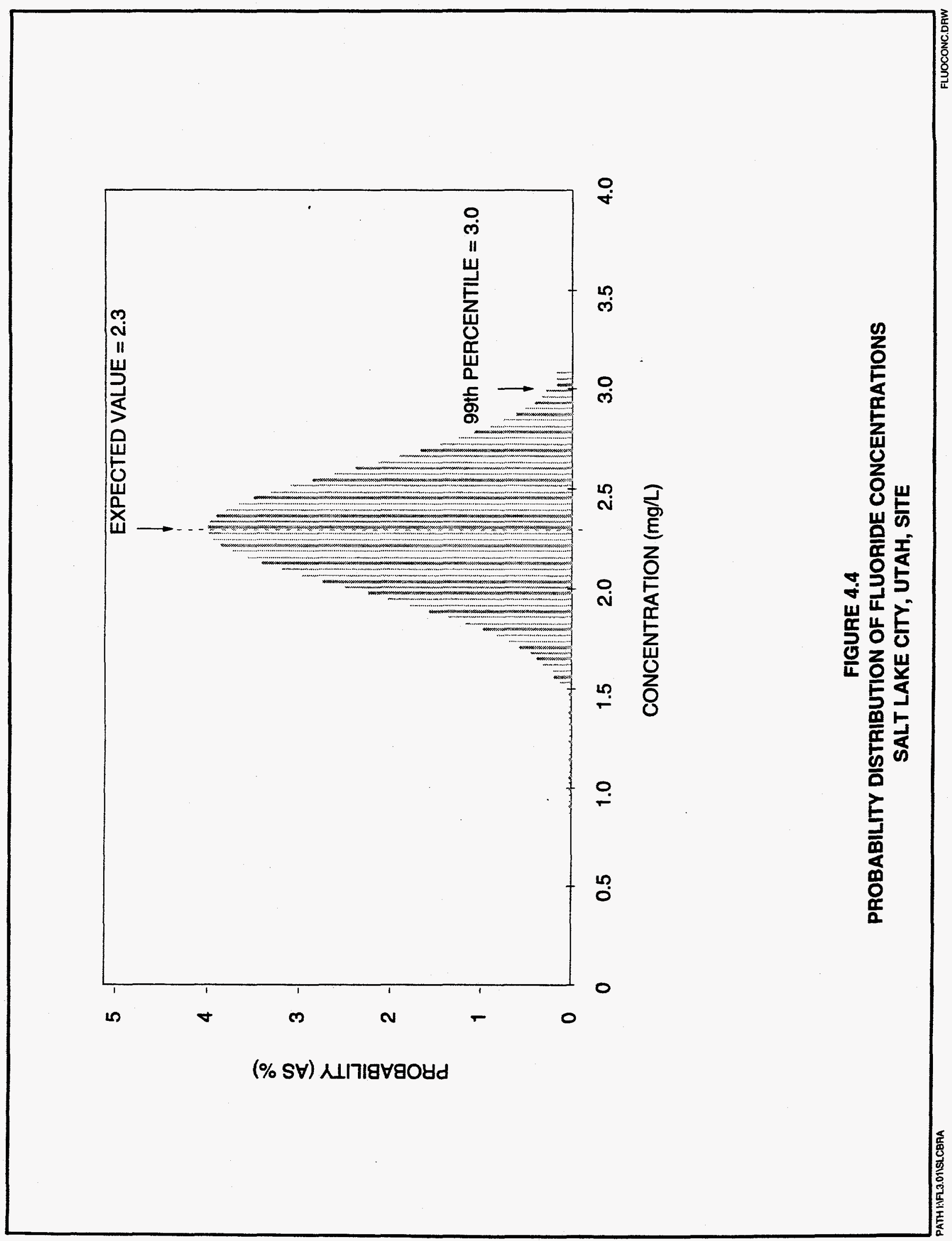




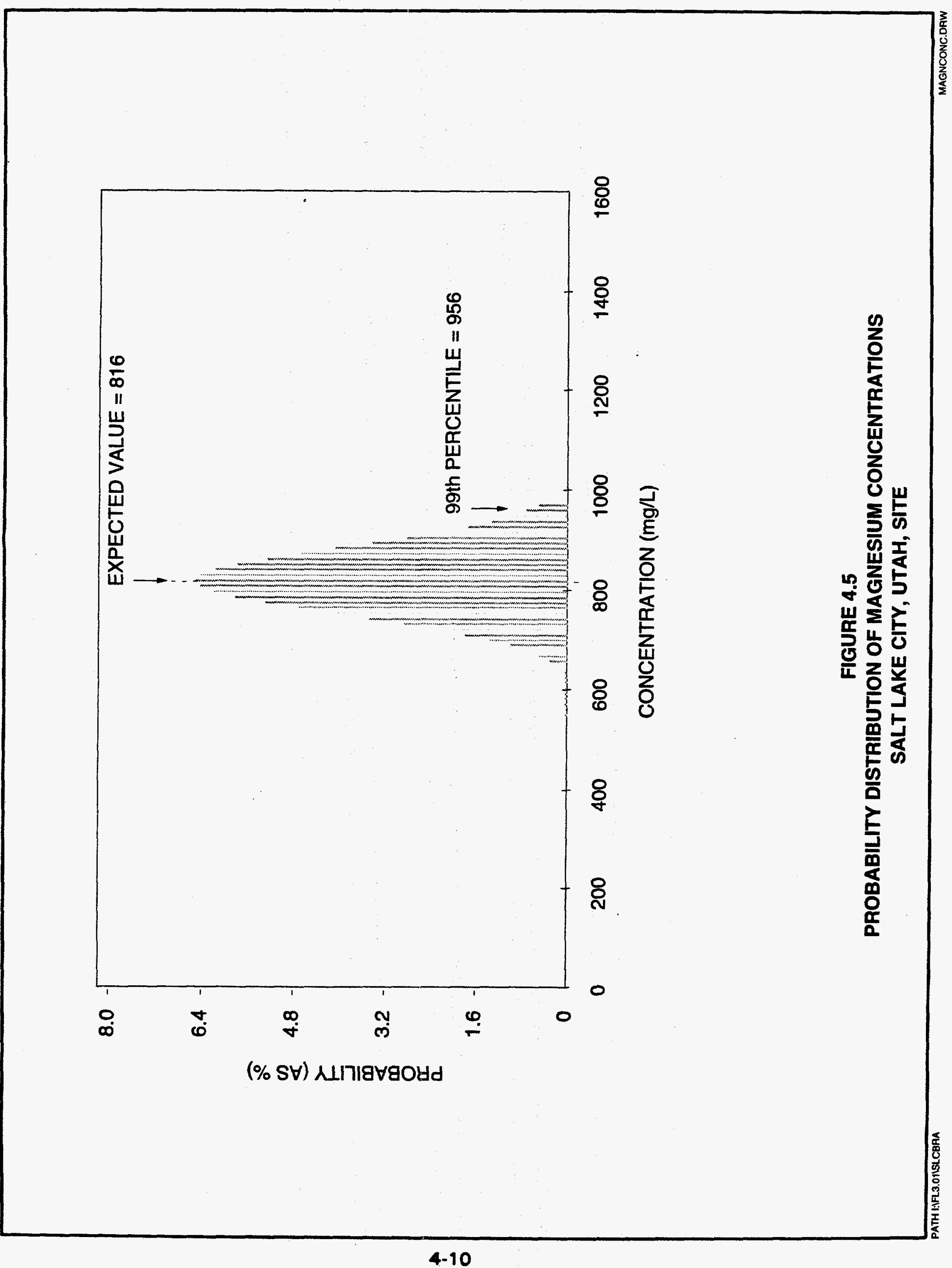




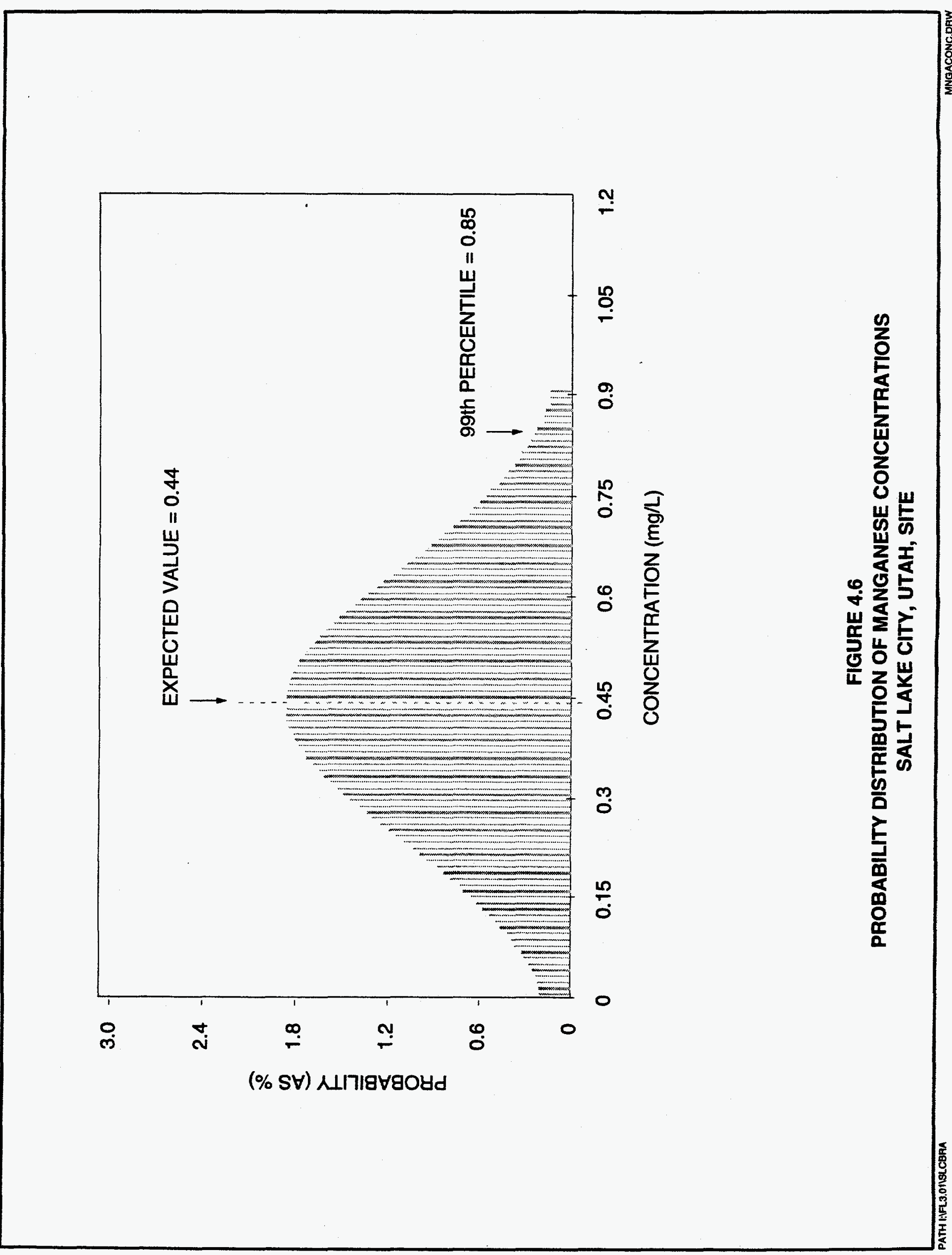




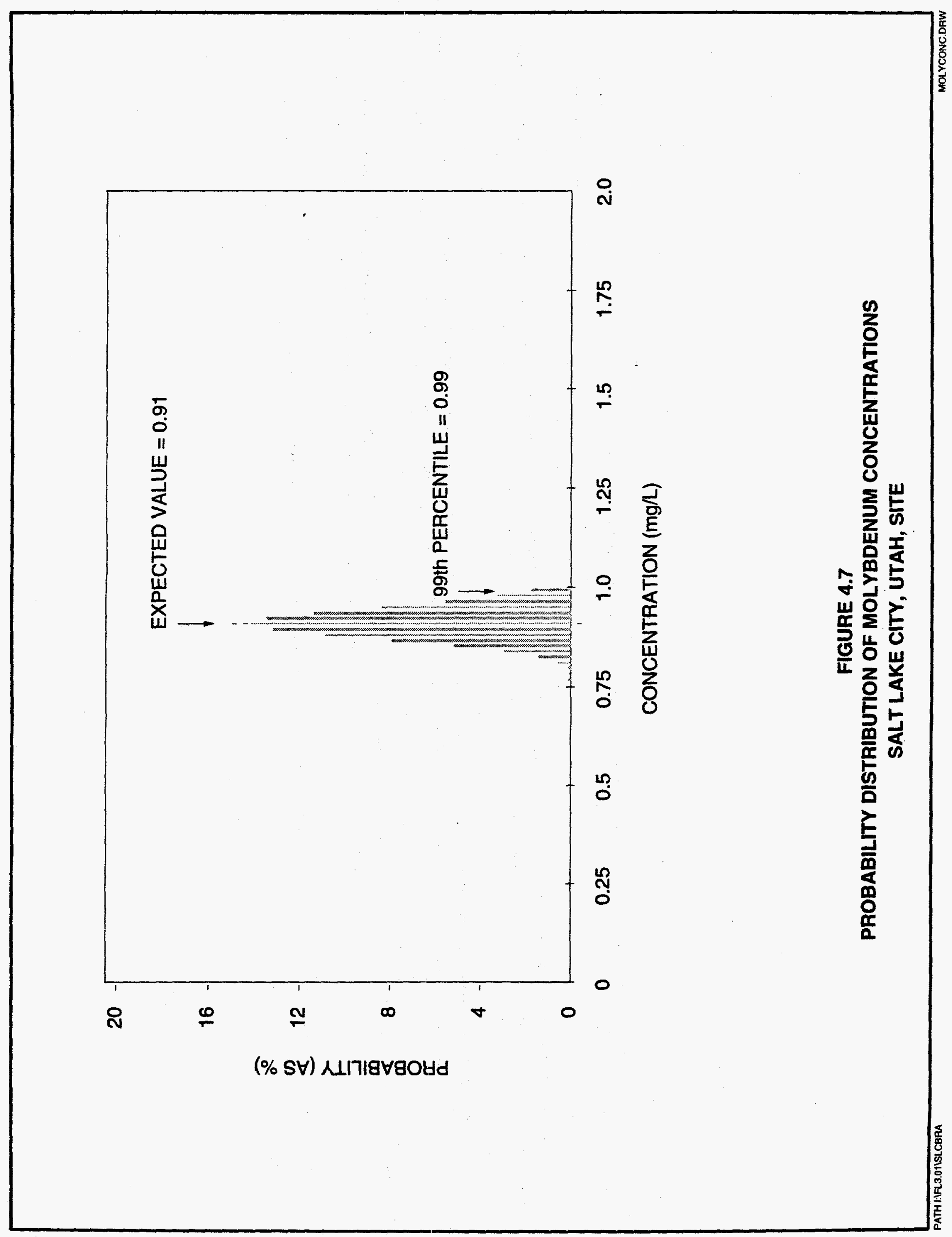




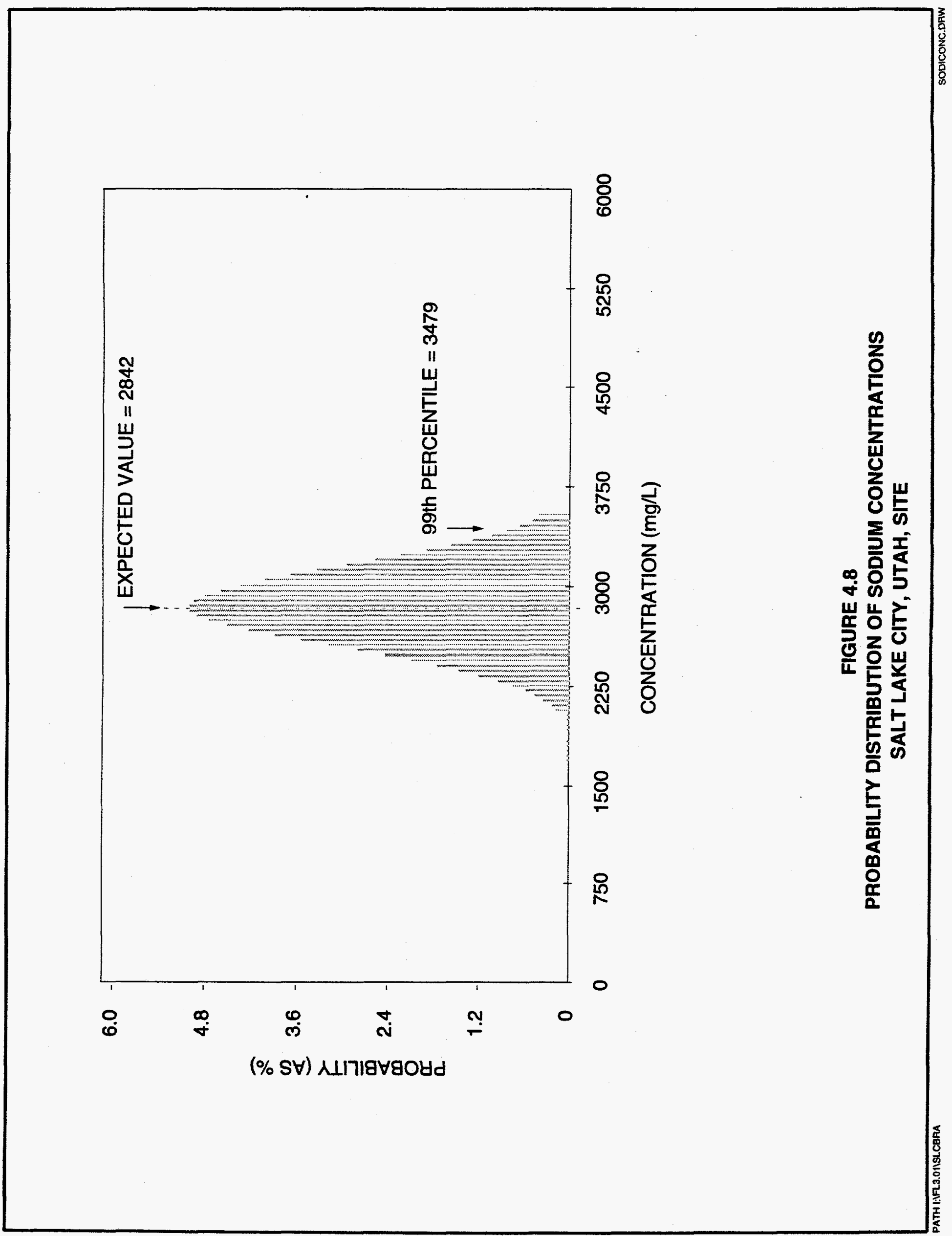




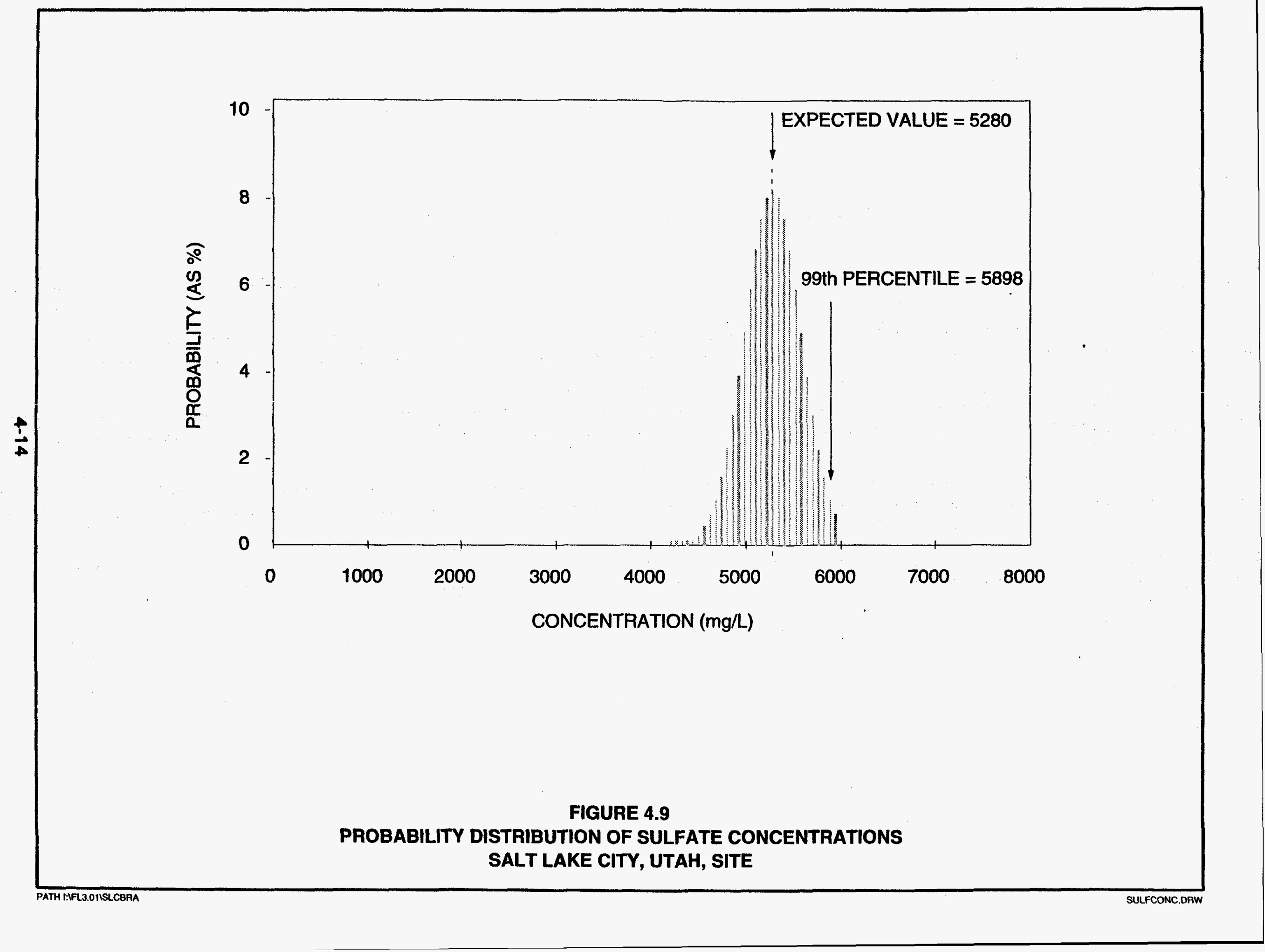




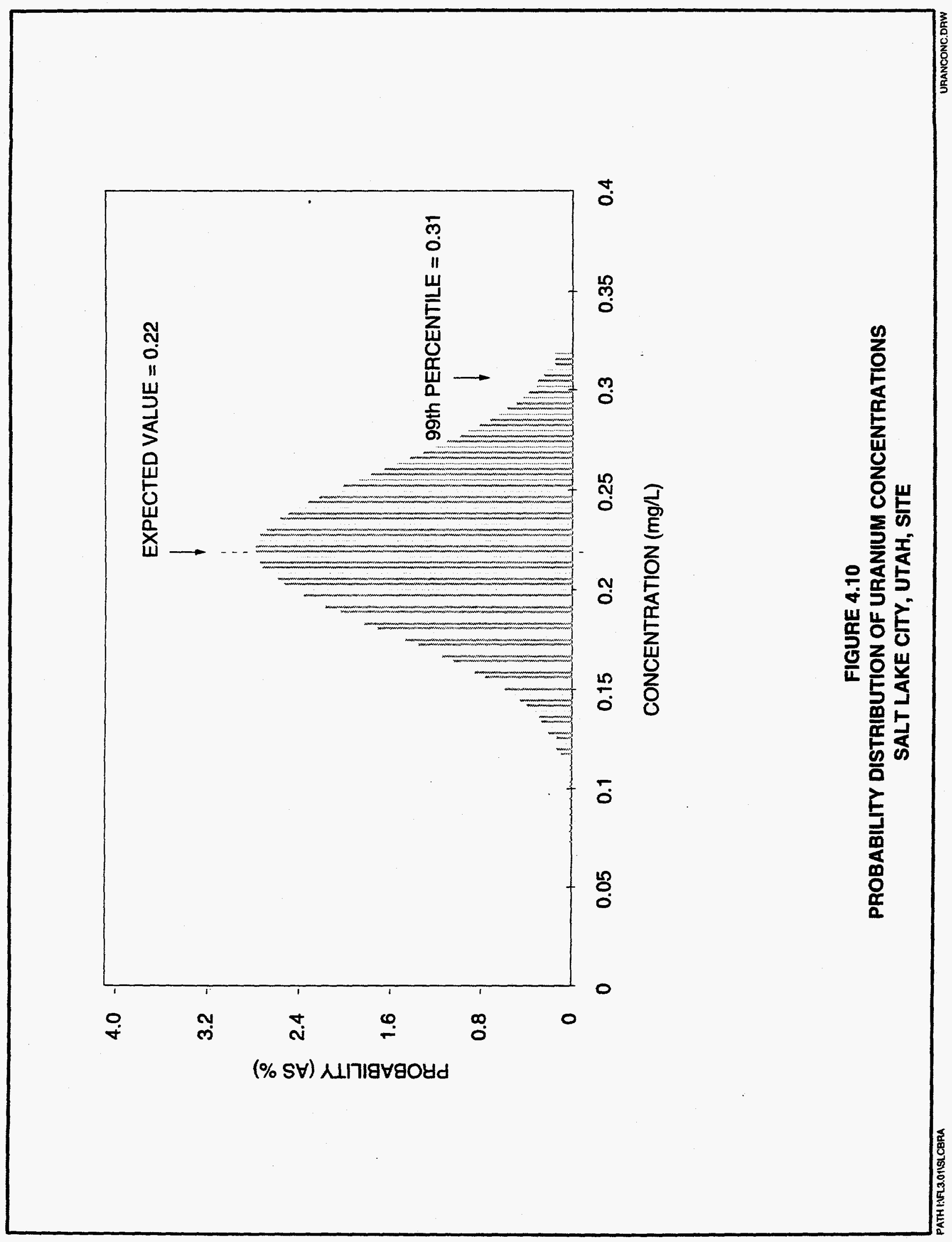


during a 3-day period was recorded for 26,081 survey participants nationwide (Figure 4.11).

\section{Body weight $(\mathbf{k g})$}

Extensive national data on weights of males and females, by age, were collected by the National Health and Nutrition Survey between 1976 and 1980 . These data were used to develop lognormal probability distributions for body weight by age and by sex. Then the distributions for males and females were combined, using census data on the national ratio of males and females within each age group (Figure 4.12).

\section{Exposure frequency (days/vear)}

Individuals are generally not in their homes and drinking water from the same source for 365 days per year. Therefore, intake calculations assume only 350 days of exposure per year, allowing 14 days per year of drinking water intake from a different source. Because exposure to noncarcinogenic chemicals is expressed and compared in terms of average daily intake, 365 days per year is retained in the averaging-time term in the denominator.

\section{Exposure duration (vears)}

Distributions of exposure duration were developed using data collected in 1985 and 1987 by the U.S. Department of Commerce, the Bureau of the Census, and the U.S. Department of Housing and Urban Development (Israeli and Nelson, 1992).

For noncarcinogens, the exposure duration in the numerator and denominator and the averaging time of the drinking water intake equations (see equation (1)) cancels out, assuming all exposures are chronic (i.e., at least 7 years). Thus, deviation from the standard residence time assumptions does not affect the results. For carcinogens, however, because risk is cumulative throughout a lifetime, deviation from the hypothesized residency distribution could considerably affect the risk estimate. Because residents living near the Vitro site frequently live in the same region for almost their entire lives, a fixed lifetime exposure of 30 years was used to model lifetime cancer risks.

Using exposure concentration distributions from Section 4.3 and the intake parameter distributions from this section, total intake distributions were determined for the three age groups $(0$ to 1,1 to 10 and 11 to 65 years old) by simulation, using the @RISK software package and 10,000 iterations (DOE, 1995a). The 1-to-10-year-old age group consistently showed the highest intaketo-body weight distributions and therefore is the most conservative age group to evaluate. This age group is likely more susceptible to metal toxicity than adults because of higher gastrointestinal absorption efficiency and other toxicokinetic factors (Casarett and Doull, 1991). However, because infants are the most 

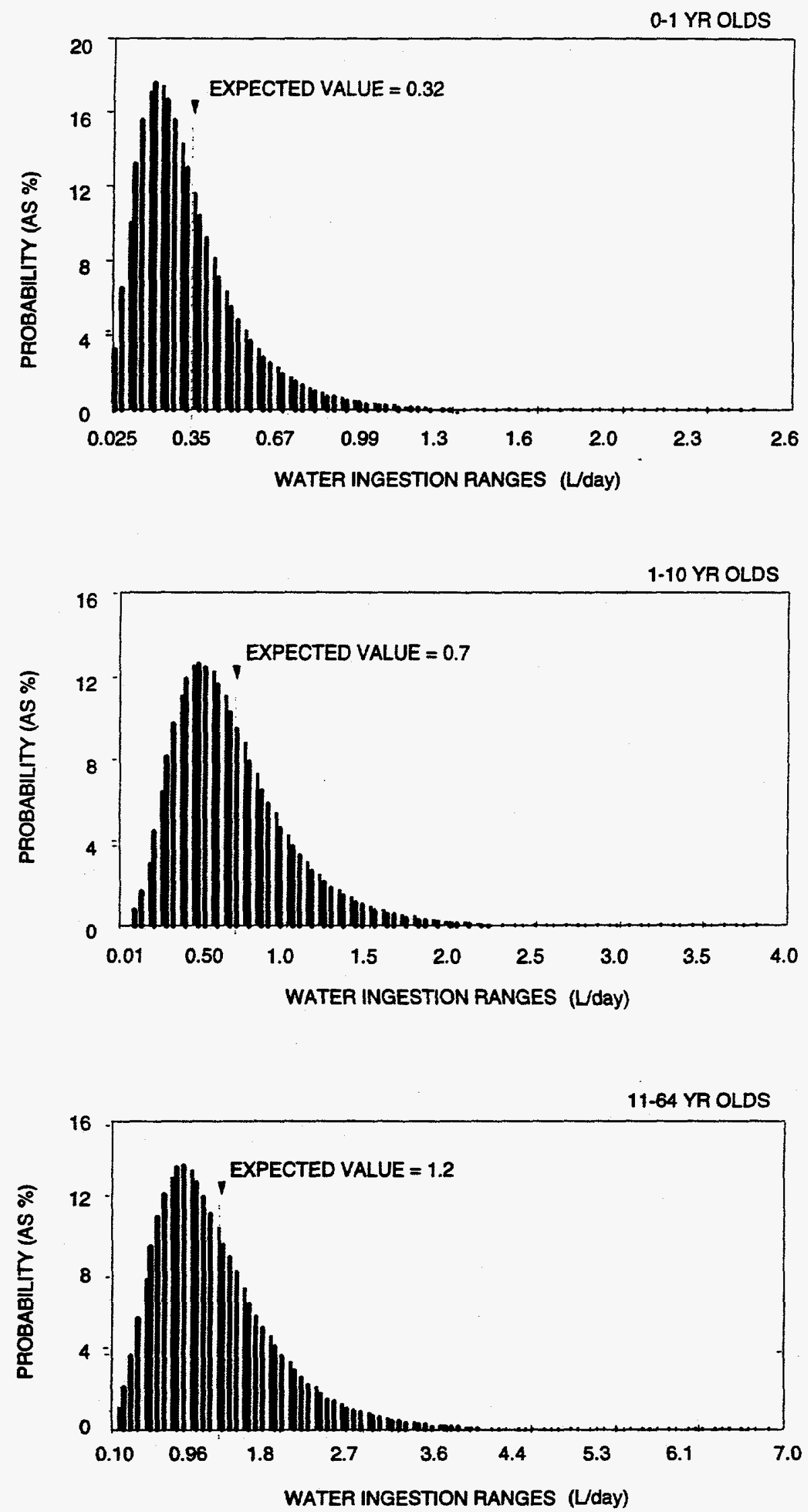

FIGURE 4.11

PROBABILITY DISTRIBUTIONS FOR TAP WATER INGESTION RATES 

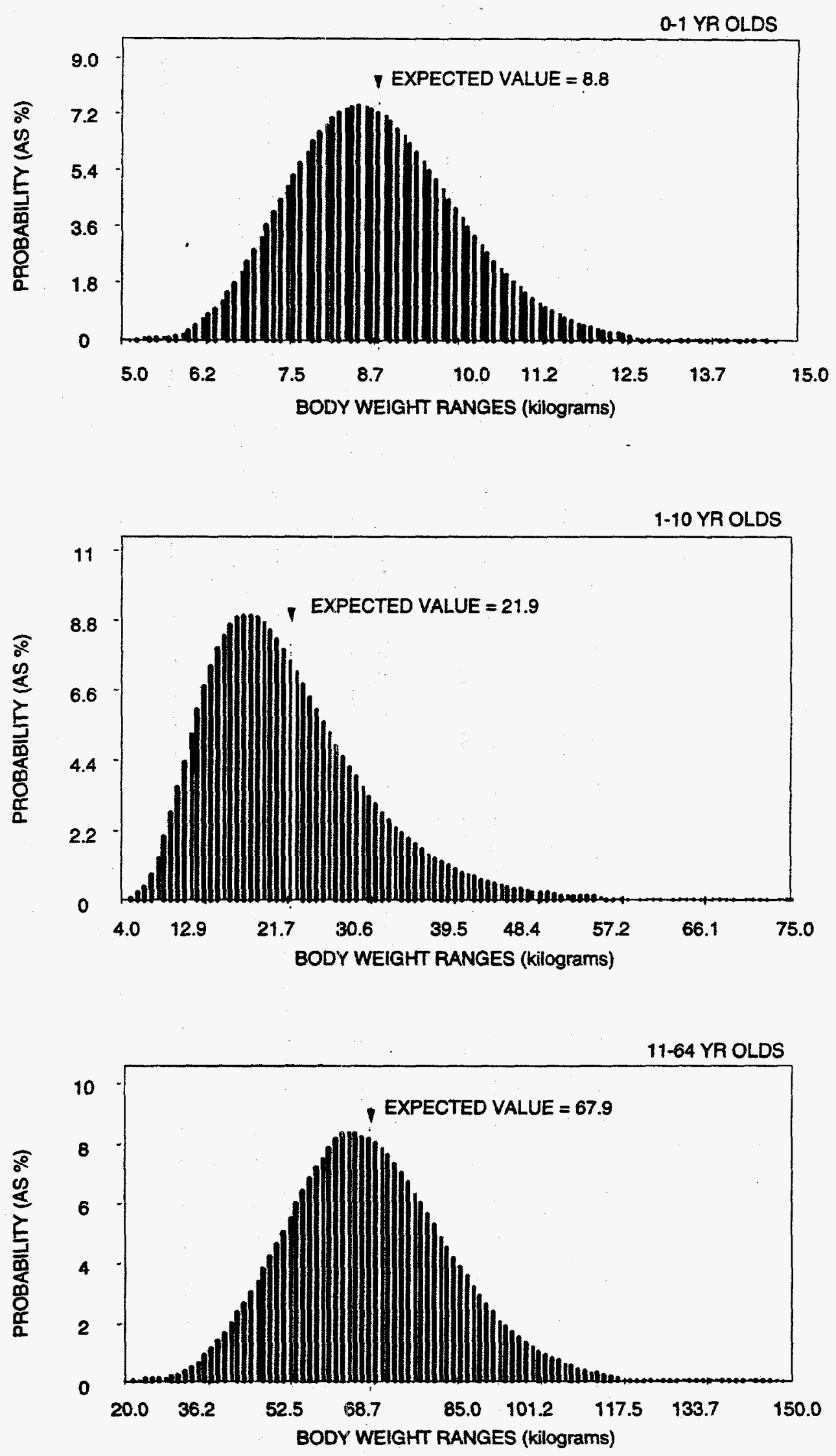

FIGURE 4.12

PROBABILITY DISTRIBUTIONS FOR BODY WEIGHT 
susceptible receptors to sulfate toxicity, the intake distribution for this age group (i.e., age 0 - to 1-year) is used. These results are shown for noncarcinogens in Figures 4.13 through 4.20. The total intake estimates used to calculate carcinogenic risk are shown in Figure 4.21 for uranium-234 and uranium-238.

\subsection{EXPOSURE ASSESSMENT UNCERTAINTIES}

Several potential sources of error may arise in all phases of an exposure assessment. Some meaningful sources of uncertainty are listed below.

- Lack of thorough environmental characterization of the site. The resulting uncertainty could lead to an underestimate or overestimate in the exposure analysis.

- Use of filtered versus unfiltered ground water samples. The results of exposure assessment presented in this document are based on filtered 10.45 $\mu \mathrm{m})$ ground water samples. Therefore, the potential loss of certain ground water constituents as a consequence of filtration is associated with an additional source of uncertainties. For example, if concentrations of iron and lead measured in unfiltered ground water samples from monitor well 131 represent true values, ingesting this water could cause toxic effects.

Because a high dose of uncertainty (see Section 3.0) is associated with these results, they could not be used in this risk evaluation.

- Assumption that the ground water contaminant source term at the site has reached a steady state and that contaminant concentrations at the exposure point will remain constant for chronic periods of exposure (generally greater than 7 years).

Additivity of exposure from other pathways. Although the drinking water ingestion pathway is considered the major determinant of exposure in this risk assessment, the incremental contribution from the ground water-irrigated produce-ingestion pathway (that could not be estimated here) should be considered.

- Estimating the amount of contaminant absorbed through the skin.

Despite these uncertainties, using probability distributions that incorporate all definable sources of variability provide a representative picture of the potential range of exposure from drinking water ingestion pathway. 


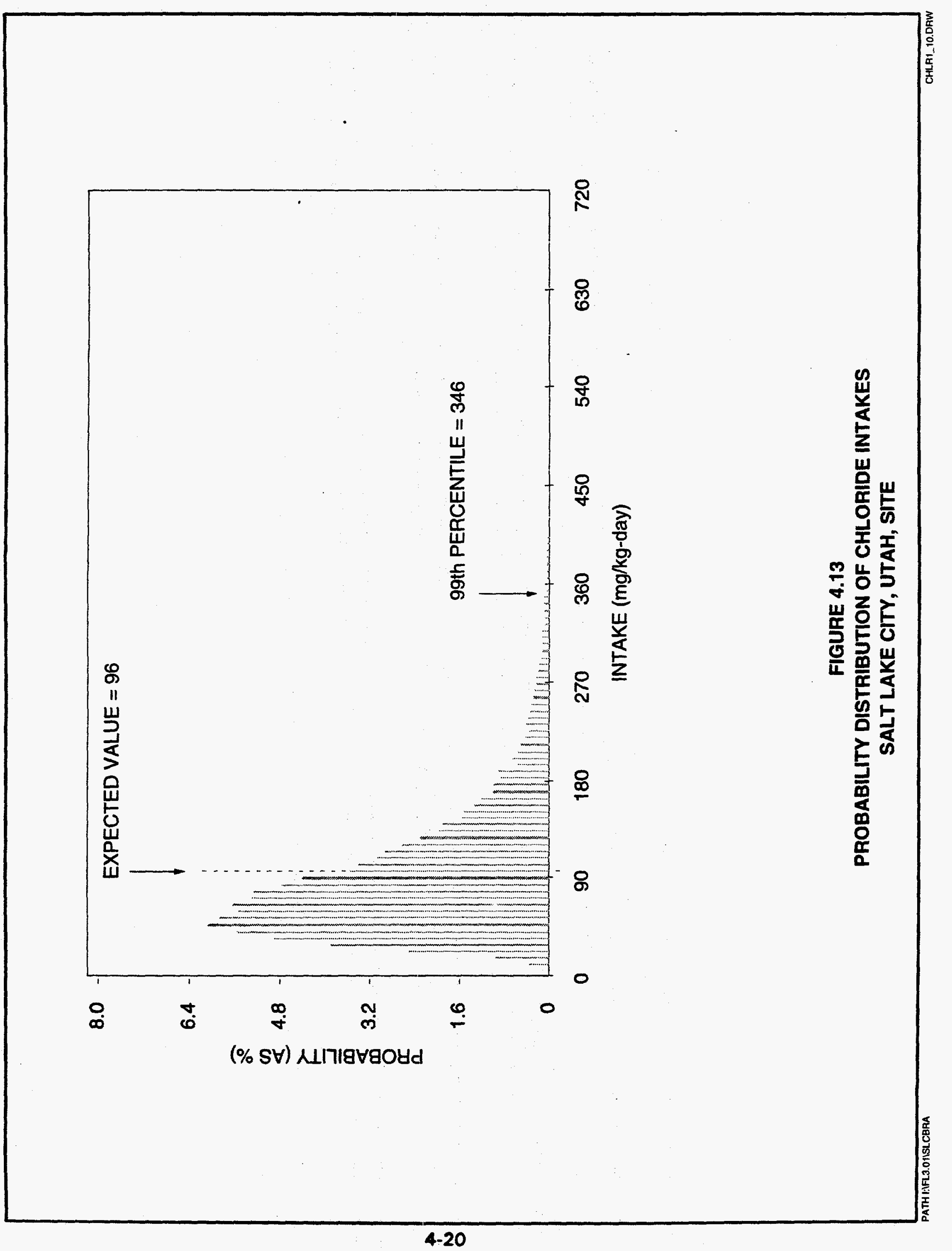




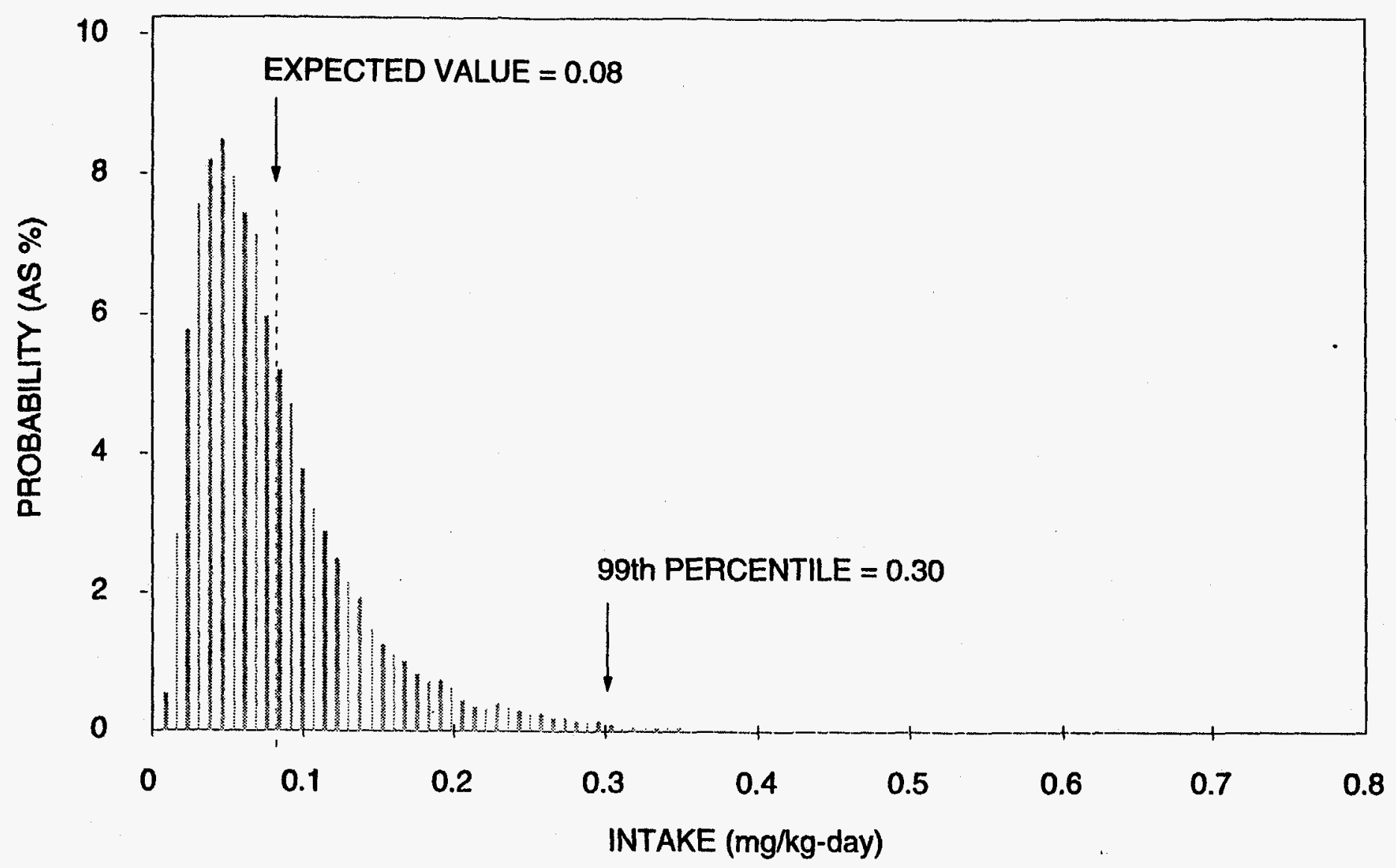

FIGURE 4.14

PROBABILITY DISTRIBUTION OF FLUORIDE INTAKES

SALT LAKE CITY, UTAH, SITE 


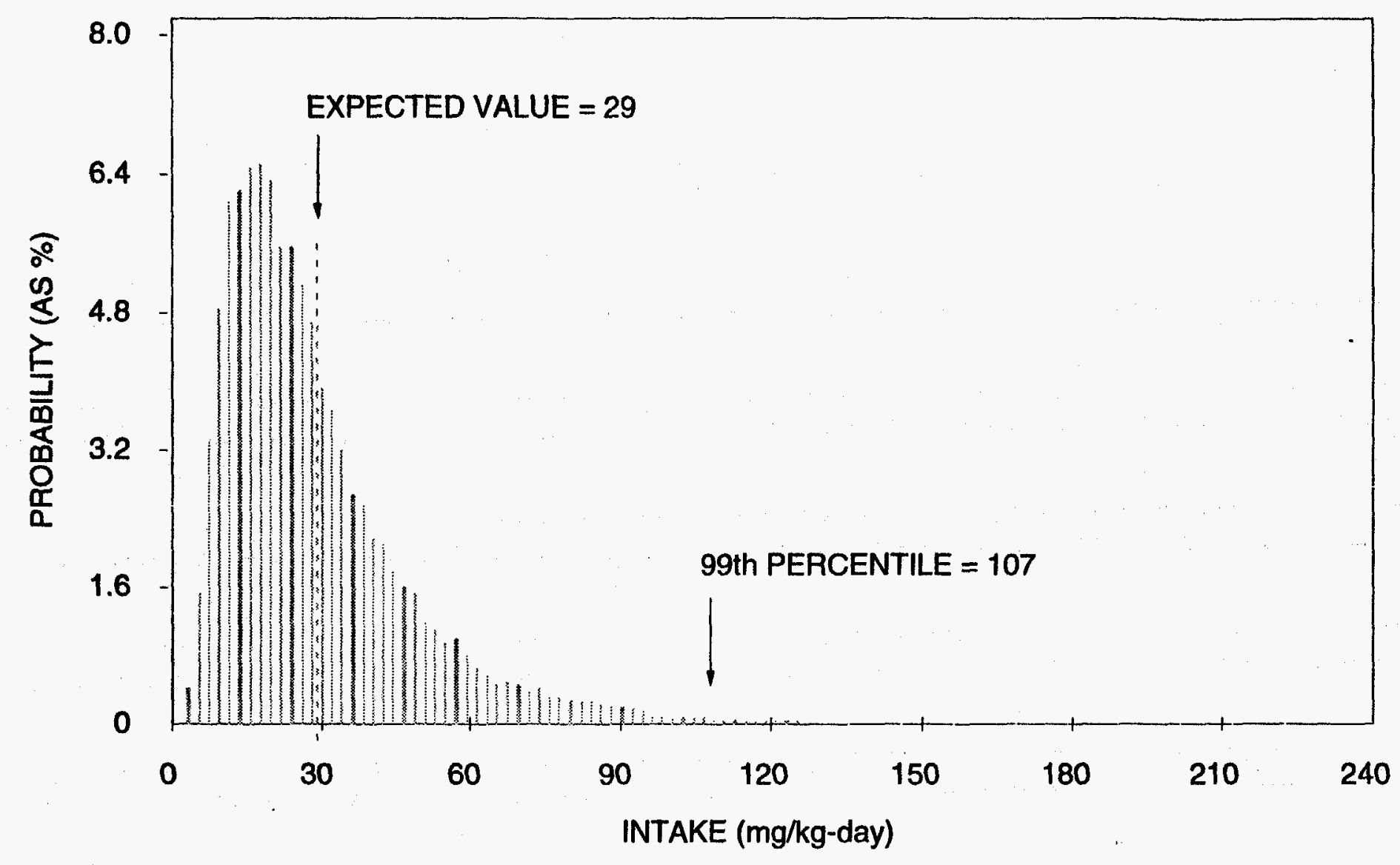

FIGURE 4.15

PROBABILITY DISTRIBUTION OF MAGNESIUM INTAKES

SALT LAKE CITY, UTAH, SITE 


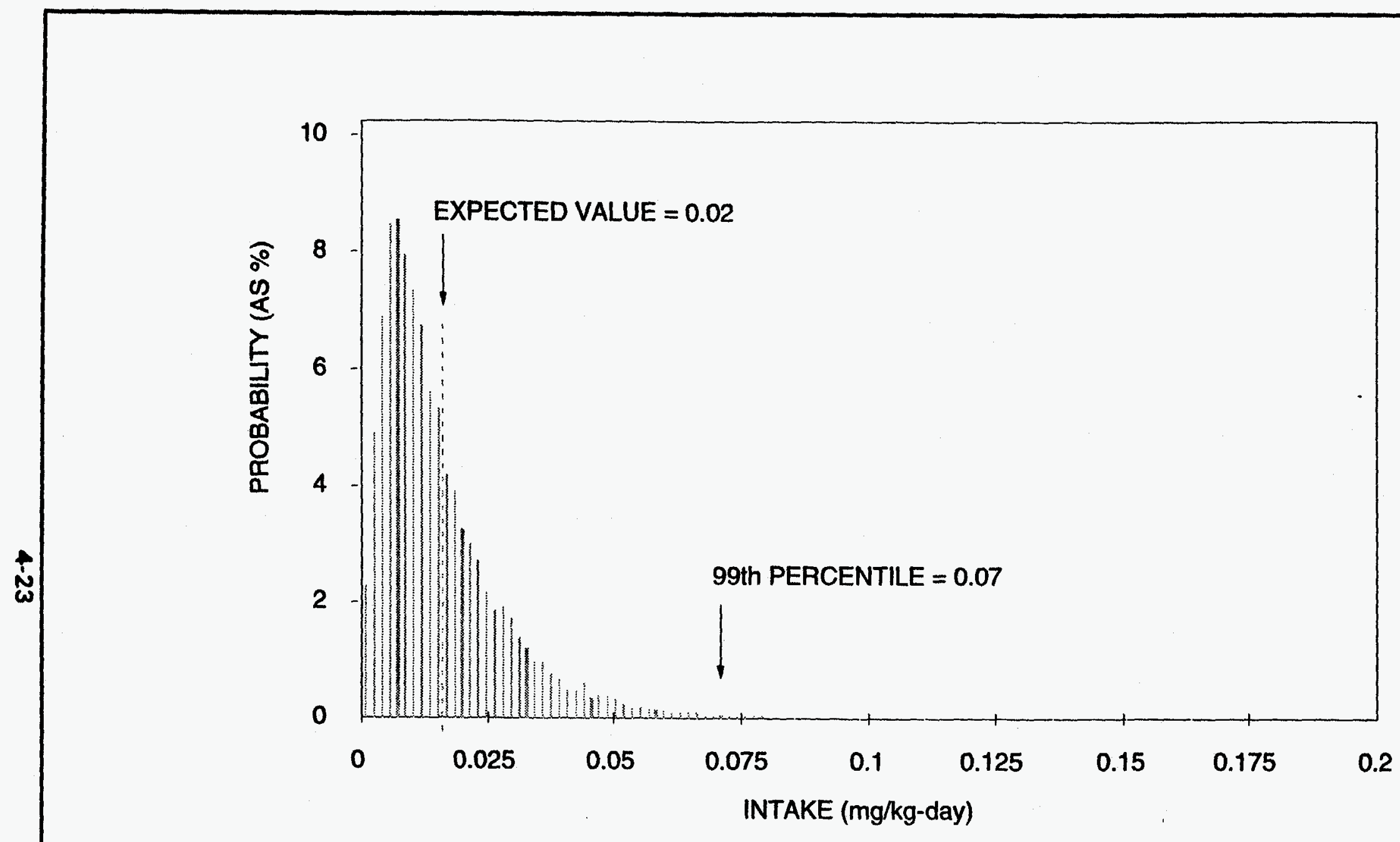

FIGURE 4.16

PROBABILITY DISTRIBUTION OF MANGANESE INTAKES

SALT LAKE CITY, UTAH, SITE 


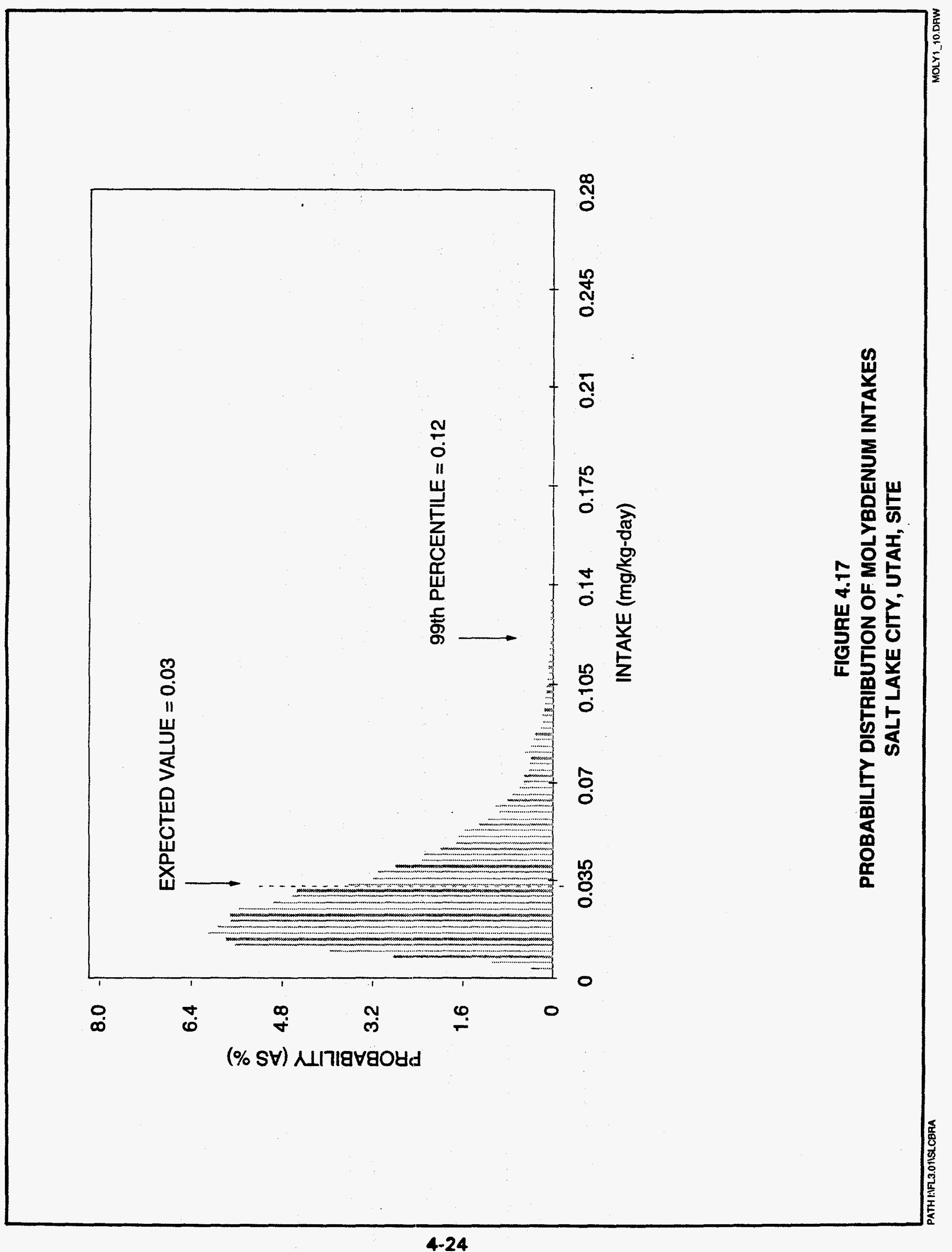




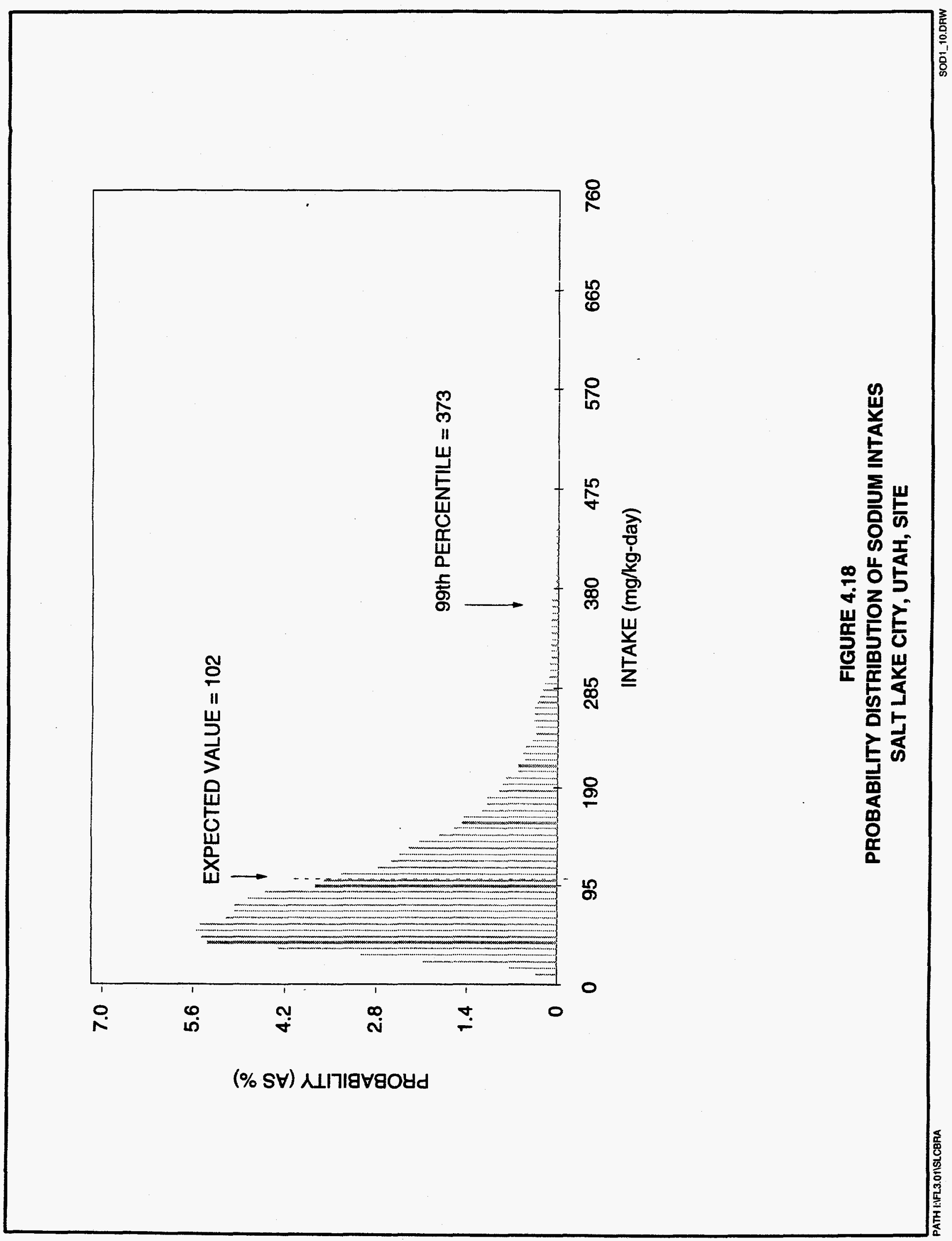




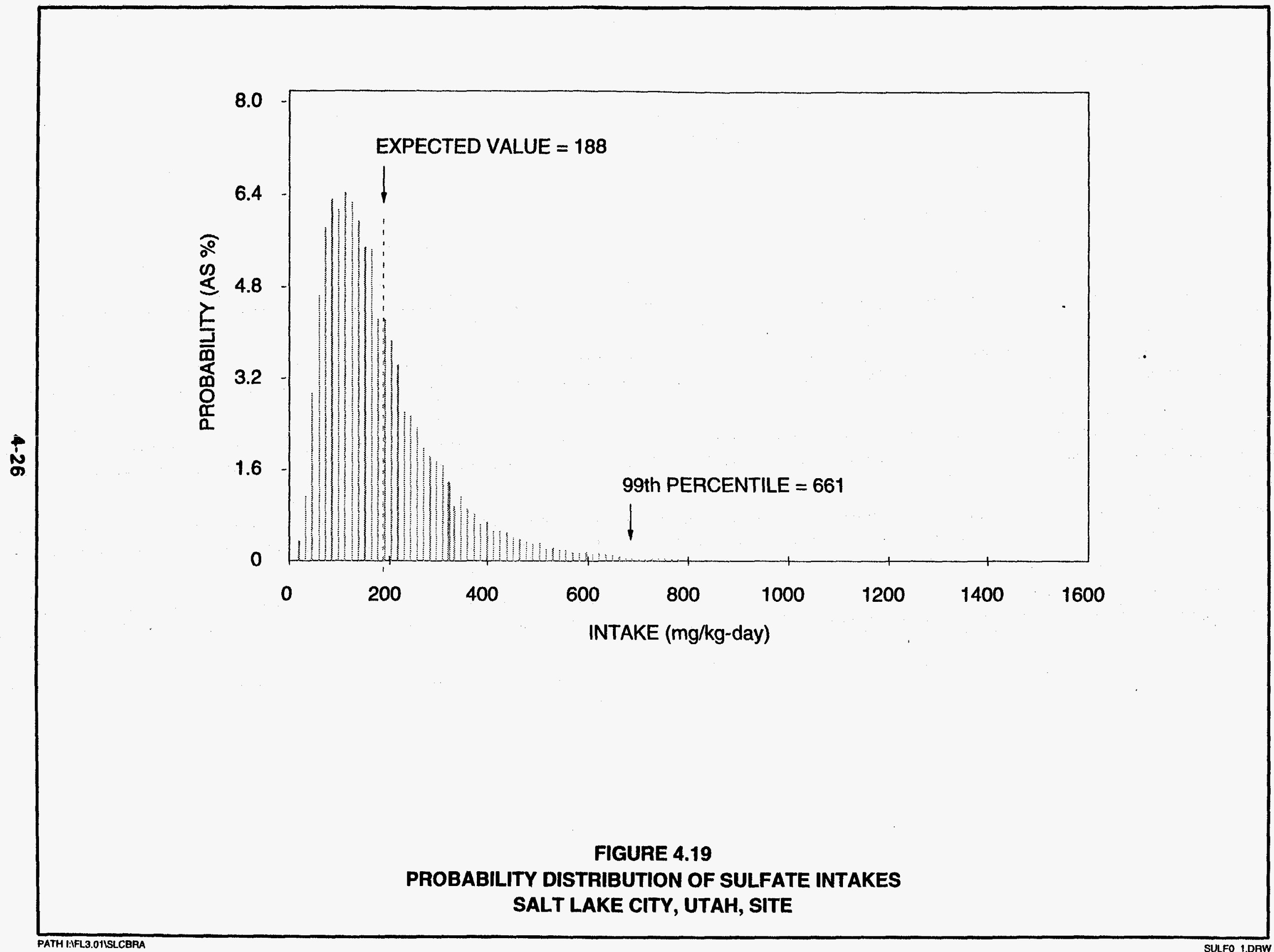




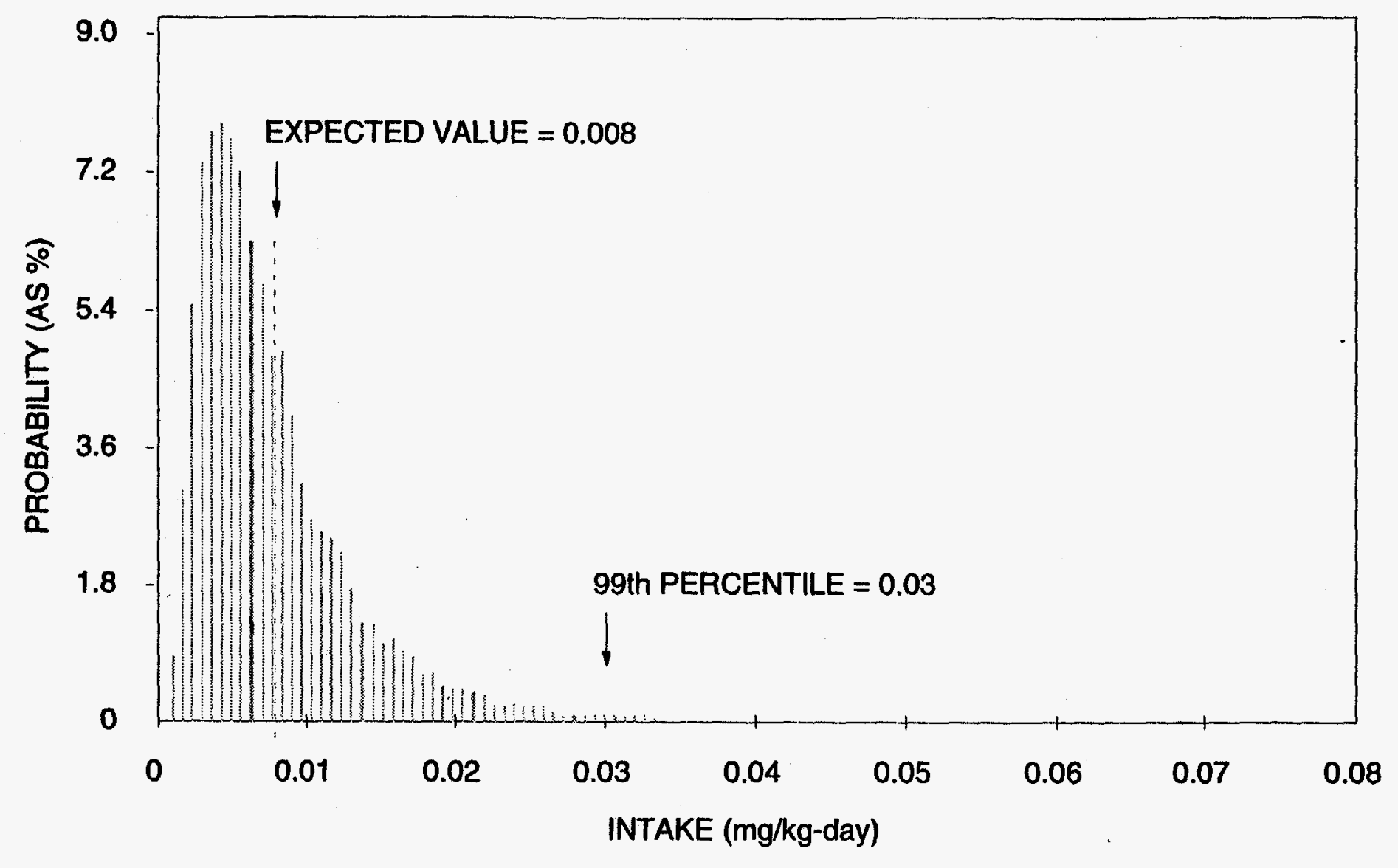

FIGURE 4.20

PROBABILITY DISTRIBUTION OF URANIUM INTAKES

SALT LAKE CITY, UTAH, SITE 


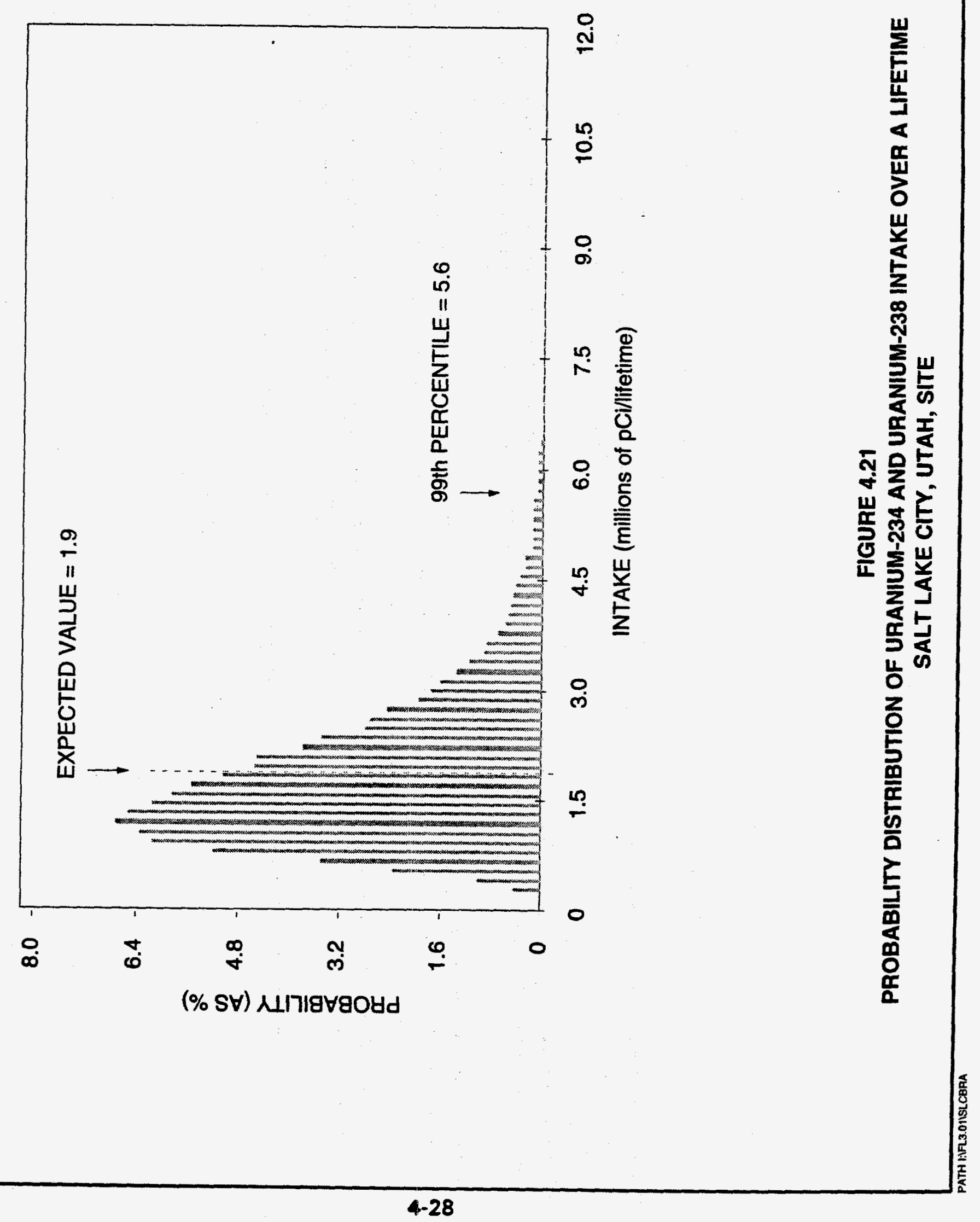




\subsection{TOXICITY ASSESSMENT}

Several contaminants that could adversely affect health and the environment have been detected in ground water at the site.

The following source materials were used to develop toxicological profiles on these chemical contaminants and the potentially carcinogenic radionuclides: Integrated Risk Information System (IRIS) (EPA, 1994a); the Agency for Toxic Substances and Disease Registry Toxicological Profiles published by the Department of Health and Human Services (DHHS); the Handbook on the Toxicology of Metals (Friberg et al., 1986); and peerreviewed scientific literature when these review documents were not available. Basing toxicity information on the standardized review documents cited above ensures consistency in risk evaluation at all UMTRA sites.

The toxicity profiles presented here focus on drinking water data in humans, including animal information only when human data are not available. Animal data are represented on the toxicity range graphs by widely spaced, dotted lines. Uncertainty about the beginning or ending point of an exposure range that produces specific toxic effects is represented by closely spaced dots.

\subsection{CONTAMINANT TOXICITY SUMMARIES}

The following paragraphs address the basic toxicokinetics and toxicity of the 12 contaminants of potential concern at the Salt Lake City uranium processing site. The contaminants of potential concern are chloride, fluoride, magnesium, manganese, molybdenum, sodium, sulfate, uranium and its decay products (radium-226, lead-210, polonium-210, and thorium-230). Although the toxic effects of these contaminants vary with exposure levels, toxic effects observed in the exposure range most relevant to contamination at this site are discussed in this report.

\subsubsection{Chloride}

\section{Absorption, tissue accumulation, and clearance}

Chloride is rapidly and fully absorbed from the gastrointestinal tract. The chloride concentration in the human body is approximately $2000 \mathrm{mg} / \mathrm{kg}$ of fat-free body mass in newborns and $1920 \mathrm{mg} / \mathrm{kg}$ in adults (National Research Council, 1980). Chloride occurs in plasma at concentrations of 96 to 106 milliequivalents per liter (meq/L) $(3400$ to $3800 \mathrm{mg} / \mathrm{L}$ ) and in a more concentrated form in cerebrospinal fluid and gastrointestinal secretions (National Research Council, 1989). Its concentration in most cells is low. The daily chloride turnover in adults (intake/output) ranges from 3000 to $8900 \mathrm{mg}$. Chloride is excreted mainly through urine, with appreciable amounts also excreted in feces, sweat, and tears. 


\section{Environmental sources of chloride}

Dietary chloride comes almost entirely from sodium chloride (National Research Council, 1989). Much smaller amounts are supplied from potassium chloride. Thus, dietary sources of chloride (processed foods) essentially are the same as those for sodium. Rich sources of chloride are salt, cereals, breads, dried skim milk, teas, eggs, margarine, salted butter, bacon, ham, corned beef, canned meats, fish and vegetables, salted snack foods, and olives. Dietary chloride intake varies largely with salt intake. Estimates range from 2400 to $14,400 \mathrm{mg}$ chloride/day from sodium chloride (equivalent to 34 to $206 \mathrm{mg} / \mathrm{kg}$-day for a 70 $\mathrm{kg}$ man).

Human breast milk contains $11 \mathrm{meq} / \mathrm{L}$ of chloride $(391 \mathrm{mg} / \mathrm{L})$; a similar level has been suggested by the American Academy of Pediatrics for infant formulas (National Research Council, 1989).

Chloride is found in all natural water. Surface water contains only a few milligrams of chloride per liter, whereas streams in arid or semiarid regions contain several hundred milligrams per liter, especially in drained areas where chlorides occur in natural deposits or are concentrated from soils through evaporation. Contamination with sewage increases the chloride content of river water. Ground water usually contains larger quantities of chloride than surface water. Some public supply wells may contain $100 \mathrm{mg} / \mathrm{L}$ of chloride (about $3 \mathrm{mg} / \mathrm{kg}$-day, assuming $2 \mathrm{~L}$ of water are consumed per $70 \mathrm{~kg}$ of body weight) (National Research Council, 1980).

A typical chloride concentration in drinking water of about $21 \mathrm{mg} / \mathrm{L}$ would contribute $0.6 \mathrm{mg} / \mathrm{kg}$-day lassuming $2 \mathrm{~L}$ per day consumption rate and $70 \mathrm{~kg}$ of body weight), or about 2 percent of the lower estimates of total chloride intake.

The recommended drinking water level for chloride is $250 \mathrm{mg} / \mathrm{L}$ lequivalent to $7 \mathrm{mg} / \mathrm{kg}$-day, for a $70-\mathrm{kg}$ man consuming $2 \mathrm{~L}$ of water per day) (National Research Council, 1980). This amount of chloride in drinking water can cause an objectionably salty taste in water. The taste threshold for the chloride anion in water varies from 210 to $310 \mathrm{mg} / \mathrm{L}$.

\section{Toxicity of chloride}

Chloride is an important inorganic anion in the extracellular fluid compartment. It is essential in maintaining fluid and electrolyte balance and is a necessary component of gastric juice.

Chloride loss from the body generally parallels sodium loss. Thus, conditions associated with sodium depletion (e.g., heavy, persistent sweating; chronic diarrhea or vomiting; trauma; renal disease) will also cause chloride loss, resulting in hypochloremic metabolic alkalosis. 
Although the basic need for chloride is generally recognized, a recommended daily allowance (RDA) has not been determined. The estimated minimum requirement for healthy persons ranges from $180 \mathrm{mg} /$ day for infants to $750 \mathrm{mg} /$ day for adults (National Research Council, 1989).

The toxicity of salts containing the chloride ion depends primarily on the characteristic of the cation (National Research Council, 1980; 1989).

Large amounts of chloride intake may cause an increased chloride plasma concentration and a decreased bicarbonate plasma concentration, with an acidifying effect. This reaction results in hyperkalemic metabolic acidosis (National Research Council, 1980). When metabolic acidosis develops, potassium leaves the cells and is excreted by the kidney (Brater, 1992).

The only known dietary hyperchloremia results from water-deficiency dehydration. Sustained ingestion of high levels of chloride (as salt) is associated with hypertension in sensitive individuals and in animal models. Although the level of chloride attributable to hypertension has not been determined, it may be estimated based on the level of sodium intake (from sodium chloride) causing hypertension in approximately 15 percent of adults (Freis, 1976). This indirectly estimated amount of chloride presumably associated with hypertension in sensitive individuals would be in the range of 36 to $180 \mathrm{mg} / \mathrm{kg}$-day.

Figure 5.1 shows the toxicity of chloride as a function of dose.

\subsubsection{Fluoride}

\section{Absorption}

Fluorides in water are absorbed primarily from the gastrointestinal tract, with the degree of fluoride absorption depending on the solubility of a particular fluoride compound.

Fluoride is absorbed differently from food and drinking water. The absorption of fluoride from water is estimated to be 100 percent, while protein-binding in food sources reduces dietary fluoride absorption. Fluoride absorption from milk or baby formula is determined to be only 72 and 65 percent, respectively, of that from water (National Research Council, 1989). Poorer absorption, from 37 to 54 percent, has been reported for the fluorine in bone meal.

\section{Tissue accumulation and clearance}

Fluoride has been detected in all organs and tissues. Following gastrointestinal absorption, fluoride is distributed primarily to bones and is deposited in the skeleton and tooth enamel with lesser deposition in the thyroid, aorta, and kidney (Gilman et al., 1990; National Research Council, 1989). The degree of skeletal storage is related to intake and age. Storage in bone is thought to be a function of the turnover rate of skeletal components, with growing bone 


\begin{tabular}{|c|c|c|c|c|c|c|c|}
\hline & $T$ & 1 & 1 & $T$ & $T$ & $T$ & $T$ \\
\hline 0 & 50 & 100 & 150 & 200 & 250 & 300 & 350 \\
\hline
\end{tabular}

I

INTAKE FAOM DRINKING WATER

$\triangle$ RECOMMENDED INTAKE LIMIT FROM WATER

DIETARY INTAKE LEVELS

........

HYPERTENSION IN HUMANS (DOSE RECONSTRUCTION;

BASED ON SODIUM CHLORIDE INTAKE ASSOCIATED WITH

HYPERTENSION IN HUMANS) 
showing a greater fluoride deposition than mature organisms. Prolonged periods of time are required for mobilization of fluoride from bone. The half-time for turnover in the young adult skeleton is about 8 to 10 years (Maheshwari et al., 1981).

The major route of fluoride excretion is the kidney. However, fluoride is also excreted in small amounts through the sweat glands, breast milk, and the gastrointestinal tract. Under conditions of excessive sweating, the fraction of total fluoride excretion contributed by sweating can reach nearly one half (Gilman et al., 1990). About 70 percent of the ingested fluoride is excreted in urine, and about 5 percent of that retained and absorbed is excreted in the feces (Maheshwari et al., 1981). About 90 percent of the fluoride filtered by the glomerulus is reabsorbed by the renal tubules (Gilman et al., 1990).

\section{Environmental sources of fluoride}

Drinking water and food are the primary sources of fluoride intake by humans. Drinking water, whether fluoridated or not, can contribute considerably to the total daily fluoride intake. In fluoridated areas, the contribution ranges from about 26 to 54 percent of the total intake (National Research Council, 1980). In unfluoridated areas, it ranges from about 14 to 48 percent.

Most public water supplies contain fluoride, and the majority contain less than $1 \mathrm{mg} / \mathrm{L}(0.04 \mathrm{mg} / \mathrm{kg}$-day for a $25-\mathrm{kg}$ child ingesting $1 \mathrm{~L}$ of water per day or $0.03 \mathrm{mg} / \mathrm{kg}$-day for a $70-\mathrm{kg}$ adult ingesting $2 \mathrm{~L}$ of water per day) (National Research Council, 1980). Fluoride concentrations in river water may be up to 6.5 $\mathrm{mg} / \mathrm{L}$. The concentrations in lakes may be up to $1627 \mathrm{mg} / \mathrm{L}$. The average fluoride concentration of sea water is $1.2 \mathrm{mg} / \mathrm{L}$.

The richest dietary sources of fluoride are tea and marine fish consumed with their bones (National Research Council, 1989). In the United Kingdom, tea accounted for 72 percent $(1.3 \mathrm{mg})$ of the total adult daily intake of $1.8 \mathrm{mg}$ (National Research Council, 1989). The fluoride content of cow's milk is approximately $0.02 \mathrm{mg} / \mathrm{L}$. Mean reported values for human milk range from 0.005 to $0.025 \mathrm{mg} / \mathrm{L}$, depending on maternal intake (mothers were drinking water containing 0.2 and $1.7 \mathrm{mg} / \mathrm{L}$, respectively). Dietary fluoride intake up to $3.44 \mathrm{mg} / \mathrm{day}(0.05 \mathrm{mg} / \mathrm{kg}$-day for a $70-$ $\mathrm{kg}$ adult) has been reported in some areas of the United States (National Research Council, 1980). An average fluoride dietary intake of $0.01 \mathrm{mg} / \mathrm{kg}$-day has been reported for both a $20-\mathrm{kg}$ child and a $70-\mathrm{kg}$ adult (EPA, 1994a).

Food processing substantially influences the fluoride content of foods. The fluoride content of many foods can increase severalfold by cooking in fluoridated water. Cooking in utensils treated with Teflon ${ }^{\circledR}$, a fluoride-containing polymer, can increase the fluoride content, whereas an aluminum surface can reduce it (National Research Council, 1989).

The estimated safe and adequate daily dietary intake (ESADDI) of fluoride for adults is 1.5 to $4.0 \mathrm{mg} /$ day (equivalent to 0.02 to $0.06 \mathrm{mg} / \mathrm{kg}$-day for a $70-\mathrm{kg}$ man) (National Research Council, 1989). This range accounts for widely varying 
fluoride concentrations consumed in the United States and includes both food sources and drinking water. For younger age groups, the estimated maximum level of this intake is $2.5 \mathrm{mg} /$ day (equivalent to $0.1 \mathrm{mg} / \mathrm{kg}$-day for a $25-\mathrm{kg}$ child). Ranges of 0.1 to $1 \mathrm{mg} /$ day during the first year of life (equivalent to 0.03 to 0.3 $\mathrm{mg} / \mathrm{kg}$-day for a 4-kg infant), and 0.5 to $1.5 \mathrm{mg} /$ day during the subsequent 2 years, are suggested as adequate and safe (National Research Council, 1989).

In view of fluoride's beneficial effects on dental health and its suggested safety at the ESADDI levels, the Food and Nutrition Board recommends fluoridation of public water supplies if natural fluoride levels are substantially below $0.7 \mathrm{mg} / \mathrm{L}$ (National Research Council, 1989).

\section{Toxicity of fluoride}

Although at low doses fluoride can have beneficial effects on teeth and bone, at higher doses fluoride can be toxic. Children are particularly sensitive to dental fluorosis, the critical toxic effect of fluoride (EPA, 1994a). Fluoridation of water to a concentration of $1 \mathrm{mg} / \mathrm{L} 10.04 \mathrm{mg} / \mathrm{kg}$-day for a $25-\mathrm{kg}$ child assuming ingestion of $1 \mathrm{~L}$ of water) is established as a safe and practical public health measure that results in a substantial reduction in the incidence of caries in permanent teeth (Gilman et al., 1990). Fluoride is also used to treat osteoporosis in larger doses than those used to prevent dental caries (Maheshwari et al., 1981). However, the optimal level of fluoride intake for osteoporosis therapy is not determined.

Fluoride is an inhibitor of several enzyme systems and diminishes tissue respiration and anaerobic glycolysis. It also binds $\mathrm{Ca}(+2)$, and inhibits the glycolytic utilization of glucose by erythrocytes (Gilman et al., 1990).

Acute fluoride poisoning usually results from accidental ingestion of insecticides or rodenticides containing fluoride salts (Gilman et al., 1990). The lethal dose of fluoride for a $70-\mathrm{kg}$ adult is approximately $32 \mathrm{mg} / \mathrm{kg}$.

In man, the major manifestations of chronic ingestion of excessive amounts of fluoride are dental fluorosis (mottled enamel) and osteosclerosis (crippling skeletal fluorosis) (Gilman et al., 1990; National Research Council, 1989; Casarett and Doull, 1991). Long-term exposure to excess fluoride causes increased osteoblastic activity (a process of bone development).

In very mild tooth mottling, the gross changes consist of small, opaque, paperwhite areas scattered irregularly over the tooth surface. In severe cases, discrete or confluent, deep brown- to black-stained pits give the tooth a corroded appearance. Mottled enamel or dental fluorosis is the result of a partial failure of the enamel-forming cells to elaborate properly and lay down enamel. It is a nonspecific response to several stimuli, one of which is excessive fluoride ingestion. 
Because mottled enamel is a developmental disease, fluoride ingestion following tooth eruption has no effect on the disease (Gilman et al., 1990). Mottling is one of the first visible signs of excessive fluoride intake during childhood. Continuous use of water containing about 0.7 to $1.3 \mathrm{mg}$ fluoride/L (equivalent to 0.03 to 0.05 $\mathrm{mg} / \mathrm{kg}$-day for a $25-\mathrm{kg}$ child, assuming ingestion of $1 \mathrm{~L}$ of water per day), depending on ambient temperature and diet, produces dental mottling and changes in tooth structure in 10 percent of children (National Research Council, 1980; Gilman et al., 1990). These effects were evaluated as the very mildest form of mottled enamel. At fluoride levels of 4 to $6 \mathrm{mg} / \mathrm{L}(0.16$ to $0.24 \mathrm{mg} / \mathrm{kg}$-day for a $25 \mathrm{~kg}$ child, assuming ingestion of $1 \mathrm{~L}$ of water) the incidence reaches 100 percent, with marked increase in severity.

In osteosclerosis, as opposed to osteoporosis, bone density and calcification increases. Fluoride intoxication is thought to represent the replacement of hydroxyapatite by the denser fluorapatite. However, the mechanism of its development is unknown. The degree of skeletal involvement varies from changes that are barely detectable radiologically to marked thickening of the cortex of the long bones, numerous exostoses scattered throughout the skeleton, and calcification of ligaments, tendons, and muscle attachments to bone. In its severest form, osteosclerosis is a disabling disease and is designated as crippling fluorosis. It has been estimated that the development of crippling skeletal fluorosis in humans requires daily ingestion of 20 to $80 \mathrm{mg}$ fluoride 10.29 to $1.1 \mathrm{mg} / \mathrm{kg}$-day for a 70-kg adult) over a 10- to 20-year period (National Research Council, 1980; 1989; EPA, 1994a). Although the no observed adverse effect level (NOAEL) for crippling skeletal fluorosis in humans is unknown, a safe total fluoride exposure level (from food and drinking water) for adults is suggested to be $0.12 \mathrm{mg} / \mathrm{kg}$-day. This exposure level corresponds to the consumption of $2 \mathrm{~L}$ of water per day containing $4 \mathrm{mg}$ fluoride/ $\mathrm{L}$ by a $70 \mathrm{~kg}$ adult and ingestion of $0.01 \mathrm{mg}$ fluoride per day in the diet.

The EPA oral reference dose (RfD) of $0.06 \mathrm{mg} / \mathrm{kg}$-day was developed based on the NOAEL of $1 \mathrm{mg}$ fluoride per liter of drinking water, determined in children from 12 to 14 years old, and the assumption that a $20-\mathrm{kg}$ child consumes $0.01 \mathrm{mg}$ fluoride/kg-day in the diet (EPA, 1994a).

Figure 5.2 shows the health effects of fluoride as a function of dose.

\subsubsection{Magnesium}

\section{Absorption}

Ingested magnesium is absorbed mainly in the small intestine. Absorption of dietary magnesium has been determined to be 30 to 40 percent. Calcium and magnesium are competitive with respect to their absorptive sites, and excess calcium may partially inhibit magnesium absorption (Aikawa, 1963). 


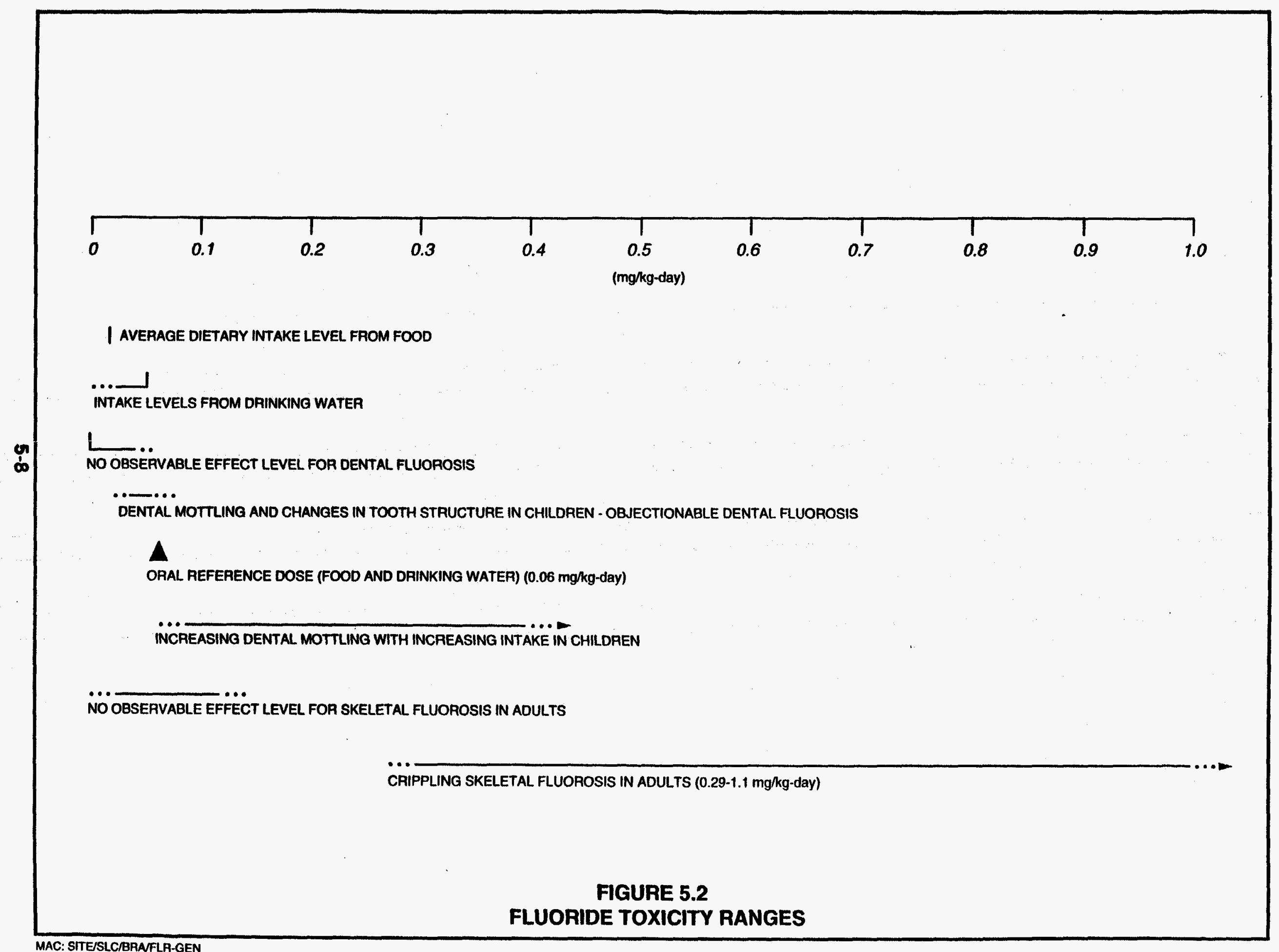




\section{Tissue accumulation and clearance}

Most magnesium in the body is in the bones. Bone magnesium seems to be a reservoir, ensuring that some magnesium will be on hand for vital reactions, regardless of dietary intake. Magnesium, a principal intracellular cation of soft tissue, is mainly a cofactor in enzymatic reactions associated with the metabolism of carbohydrates and proteins. It is also involved in neurochemical transmission and neuromuscular excitability (AHFS, 1991).

The major excretory pathway for absorbed magnesium is the kidney. In subjects on a normal diet, one-third or less of the ingested magnesium is excreted by the kidney and approximately two-thirds is excreted in the feces.

\section{Environmental sources of magnesium}

Magnesium is readily available in food, particularly nuts, cereals, seafood, and meats. The average city water supply contains about $6.5 \mathrm{mg} / \mathrm{L}$ of magnesium, but amounts vary considerably, increasing with the hardness of the water.

The magnesium RDA ranges from 4.5 to $6.7 \mathrm{mg} / \mathrm{kg}$-day. In the United States, the average adult ingests between 240 and $480 \mathrm{mg}$ of magnesium daily (from 3.4 to $6.9 \mathrm{mg} / \mathrm{kg}$-dayl.

\section{Toxicity of magnesium}

Available data on human chronic magnesium toxicity following ingestion is limited. It has been reported that therapeutic doses of ingested magnesium as low as $6.9 \mathrm{mg} / \mathrm{kg}$-day may have a laxative effect (AHFS, 1991).

In patients with severe renal impairment, hypermagnesemia (characterized by hypotension, nausea, vomiting, electrocardiogram changes, respiratory or mental depression, and coma) has occurred after administration of antacids containing magnesium (AHFS, 1991). However, the threshold dose level for these side effects has not been reported. Figure 5.3 summarizes the health effects of exposure to magnesium as a function of dose.

\subsubsection{Manganese}

\section{Absorption}

Following ingestion, manganese absorption is homeostatically controlled: the absorption rate depends on both the amount ingested and the existing manganese levels in tissue. Adults absorb approximately 3 to 4 percent of dietary manganese (Saric, 1986). Manganese can be absorbed following exposure by inhalation, ingestion, and dermal contact. In humans, available data indicate that only 3 percent of an ingested dose of manganese chloride is absorbed (Mena et al., 1969). Manganese in water appears to be more efficiently absorbed than 


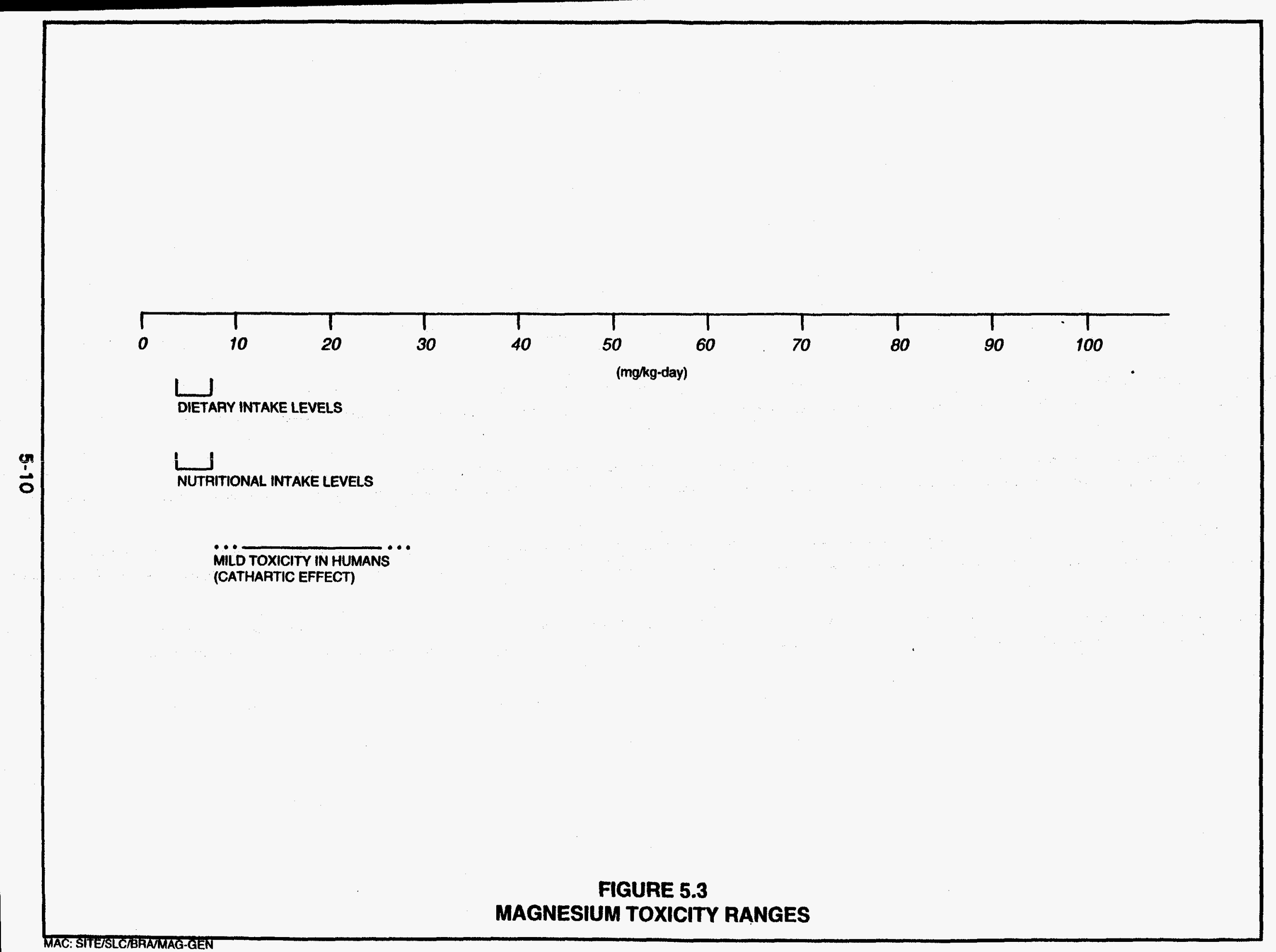


manganese in foodstuff (EPA, 1994a). The absorption rate is influenced by iron and other metals. In states of iron deficiency, manganese is actively absorbed from the intestine. Individuals with anemia can absorb more than twice the percentage of an ingested dose. However, in states of excess iron, manganese absorption is by diffusion only (Saric, 1986). High levels of dietary calcium and phosphorus are shown to increase the requirements for manganese in several species (Lönnerdal et al., 1987).

\section{Tissue accumulation and clearance}

Absorbed manganese is widely distributed throughout the body. The highest concentrations are found in the liver and kidney. The manganese elimination half-time from the human body is 2 to 5 weeks, depending on body stores. Manganese readily crosses the blood-brain barrier and is more slowly cleared from the brain than from other tissue (Goyer, 1991). Normal concentrations in the brain are low, but the half-time in the brain is longer and the metal may accumulate in the brain with excessive absorption (National Research Council, 1973).

Absorbed manganese is rapidly eliminated from the blood and concentrates in mitochondria. Initial concentrations are greatest in the liver. Manganese penetrates the placental barrier in all species and is more uniformly distributed throughout the fetus than in adults. It is secreted into milk.

Absorbed manganese is almost totally secreted in bile and reabsorbed from the intestine as needed to maintain body levels. At excessive exposure levels, other gastrointestinal routes may participate. Excess manganese is eliminated in the feces; urinary excretion is negligible (Goyer, 1991; Saric, 1986).

\section{Environmental sources of manganese}

On the whole, food constitutes the major source of manganese intake for humans. The highest manganese concentrations are found in plants, especially wheat and rice. Drinking water generally contains less than $0.1 \mathrm{mg} / \mathrm{L}$.

Manganese levels in soil range from 1 to $7000 \mathrm{mg} / \mathrm{kg}$, with an average of 600 to $900 \mathrm{mg} / \mathrm{kg}$. Mining and natural geological background variations contribute to this variability. Manganese bioaccumulates in marine mollusks up to 12,000 fold, and there is evidence for toxic effects in plants (phytotoxicity) and plant bioaccumulation. The Illinois Institute for Environmental Quality has recommended a criterion of 1 to $2 \mathrm{mg} / \mathrm{kg}$ for manganese in soil and $200 \mathrm{mg} / \mathrm{kg}$ in plants (Saric, 1986).

Variations in manganese intake can be explained to a large extent by differences in nutritional habits. In populations using cereals and rice as main food sources, the intake will be higher than in areas where meat and dairy products are a larger part of the diet. The average daily intake has been estimated to be between 2.0 to $8.8 \mathrm{mg} / \mathrm{day}(0.03$ to $0.13 \mathrm{mg} / \mathrm{kg}$-day) (EPA, 1994a), but intakes as high as 
$12.4 \mathrm{mg}$ (about $0.2 \mathrm{mg} / \mathrm{kg}$-day) are reported in countries with high cereal intake (Saric, 1986).

Drinking water generally results in an intake of less than $0.2 \mathrm{mg}$ $(0.003 \mathrm{mg} / \mathrm{kg}$-day), although some mineral waters can increase this amount by more than threefold (Saric, 1986). One study from Greece reported drinking water concentrations of manganese in excess of $2 \mathrm{mg} / \mathrm{L}$, which would result in daily intakes in the range of 0.06 to $0.07 \mathrm{mg} / \mathrm{kg}$-day (EPA, 1994a).

\section{Toxicity of manganese}

Manganese is an essential nutrient. The estimated safe and adequate daily dietary intake ranges from 0.03 to $0.07 \mathrm{mg} / \mathrm{kg}$-day for adults (Saric, 1986). The EPA no-observed-adverse-effect level (NOAEL) for drinking water is identified at $0.005 \mathrm{mg} / \mathrm{kg}$-day, while the lowest-observed-adverse-effect level (LOAEL) for drinking water is $0.06 \mathrm{mg} / \mathrm{kg}$-day (EPA, 1994a). The EPA RfD for drinking water of $0.005 \mathrm{mg} / \mathrm{kg}$-day is based on human data (Kondakis et al., 1989). The study group was a population of older adults exposed to manganese in drinking water for one lifetime; because this population was considered sensitive, an uncertainty factor of 1 was applied (EPA, 1994a). The RfD for ingested food is $0.14 \mathrm{mg} / \mathrm{kg}$-day. Manganese in drinking water may be more bioavailable (i.e., more readily absorbed) than manganese in dietary food sources. This bioavailability would result in toxic effects at lower ingested doses in drinking water than in food (EPA, 1994a).

Industrial settings are the largest source of data on chronic manganese toxicity. The data indicate that inhalation of manganese can result in a central nervous system disorder characterized by irritability, difficulty in walking, speech disturbances, and compulsive behavior that may include running, fighting, and singing. With continued exposure, this condition can progress to a mask-like face, retropulsion or propulsion, and a Parkinson-like syndrome. These effects are largely irreversible, although some recovery can be expected when exposure ceases (DHHS, 1992b). Metal-chelating agents are ineffective in treatment, but L-dopa has been effective in treatment (Gover, 1991).

Information on the effects of manganese ingestion is limited. Because effects from manganese in drinking water can appear at lower manganese levels than in food sources, only studies on water consumption will be considered here. A Japanese study of 25 people drinking well water with manganese concentrations of $14 \mathrm{mg} / \mathrm{L}(0.4 \mathrm{mg} / \mathrm{kg}$-day estimated intake) reported symptoms of intoxication, including a mask-like face, muscle rigidity and tremors, and mental disturbances. Two deaths ( 8 percent) occurred among the intoxicated people. A Greek study of more than 4000 adults at least 50 years old drinking water with manganese concentrations varying from 0.081 to $2.3 \mathrm{mg} / \mathrm{L}$ lestimated intakes at $2 \mathrm{~L} /$ day for a $70-\mathrm{kg}$ individual range from 0.002 to $0.07 \mathrm{mg} / \mathrm{kg}$-day) showed varying degrees of neurological effects in individuals drinking from 0.007 to $0.07 \mathrm{mg}$ manganese/kg-day, but no effects in individuals drinking less than 0.005 $\mathrm{mg} / \mathrm{kg}$-day (Kondakis et al., 1989). However, there are many limitations to 
these studies that make data interpretation difficult. Among the limitations is uncertainty regarding the exposure level or whether the effects seen were solely attributable to manganese. Despite these limitations, the similarity of the effects seen in the cases of oral exposure compared with those associated with inhalation exposure suggests that excess manganese intake by humans might lead to neurological injury (DHHS, 1992b).

The chemical form of manganese has complex effects on its toxicity. Although the more soluble forms are more readily absorbed from the gastrointestinal tract, they also appear to be more rapidly cleared. Exposure to insoluble forms results in lower manganese absorption but higher chronic tissue levels and therefore greater toxicity (EPA, 1994a). Information on the effects of various forms of manganese is limited.

Few data are available on manganese toxicity in infants, but infants are probably more susceptible to manganese toxicity due to greater absorption and greater penetration into the central nervous system (EPA, 1994a; Saric, 1986). Figure 5.4 summarizes manganese toxicity as a function of dose.

\title{
5.1.5 Molybdenum
}

\begin{abstract}
Absorption
Molybdenum absorption in the gastrointestinal tract depends on the species of the metal. Inorganic hexavalent forms such as molybdenum trioxide, sodium molybdate, and ammonium molybdate are readily absorbed from both food and water, whereas molybdenite is not. Based on the geochemical models for the Salt Lake City site, all of the molybdenum exists in the form of well absorbable molybdate in ground water (Table 3.6). Human absorption rates of 40 to 70 percent have been observed for the soluble forms of molybdenum (Tipton et al., 1969; Robinson et al., 1973; Alexander et al., 1974).
\end{abstract}

\section{Tissue accumulation and clearance}

In humans, the highest concentrations of molybdenum occur in the liver, kidney, and adrenals (Casarett and Doull, 1991). With normal dietary intake, molybdenum levels in the body slowly increase until approximately age 20 , then begin to decline steadily. Urine is the principal excretion route in humans. Human studies indicate that the biological half-life in humans is considerably longer than in animals and may be as long as 2 weeks (Rosoff and Spencer, 1964).

\section{Environmental sources of molybdenum}

Molybdenum occurs naturally in combination with other metals, including uranium, lead, iron, cobalt, and calcium. Native soil concentrations can vary by as much as 2 orders of magnitude, from 0.1 to $10 \mathrm{mg} / \mathrm{kg}$, leading to large 


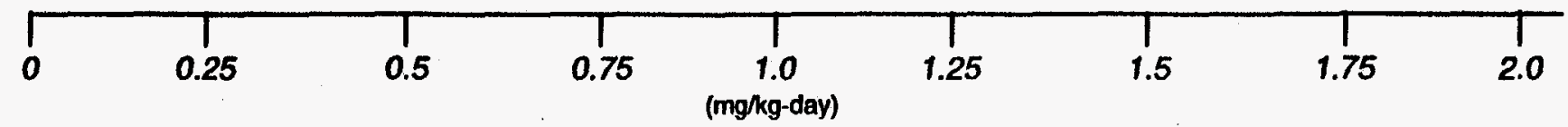

A BACKGROUND INTAKE FROM DRINKING WATER (0.003 mg/kg-day)

L」

DIETARY INTAKE FROM FOOD

ORAL REFERENCE DOSE - DRINKING WATER $(0.005 \mathrm{mg} / \mathrm{kg}$-day)

NEUROLOGICAL SYMPTOMS

P...............

PARKINSON-LIKE EFFECTS

ACUTE LETHAL DOSE, RODENTS

(400-800 $\mathrm{mg} / \mathrm{kg}$-day)

FIGURE 5.4

MANGANESE TOXICITY RANGES 
variations in molybdenum concentrations in plant materials. Natural concentrations in ground water are reported from 0.00011 to $0.0062 \mathrm{mg} / \mathrm{L}$. Human dietary intake of molybdenum is estimated at 0.05 to $0.24 \mathrm{mg} / \mathrm{day}$ $(0.0007$ to $0.003 \mathrm{mg} / \mathrm{kg}$-day). The contribution of drinking water is estimated to range from 0 to 95 percent. The nutritional intake range for molybdenum is from 0.0015 to $0.0054 \mathrm{mg} / \mathrm{kg}$-day. No symptoms of molybdenum deficiency have been reported in humans. Nonetheless, molybdenum is an essential trace element that functions as a necessary constituent of several enzymes, including xanthine oxidase (which is involved in the metabolism of uric acid) and nitrate reductase (Friberg et al., 1986).

\section{Toxicity of molybdenum}

Acute toxic effects of molybdenum have not been reported. No adverse health effects have been reported with a chronic intake of less than $0.008 \mathrm{mg} / \mathrm{kg}$-day of molybdenum (EPA, 1994a). Molybdenum toxicity primarily is related to its interactions with copper and sulfur, leading to altered excretion patterns for these elements. Increased levels of molybdenum also increase the levels of $x$ anthine oxidase, which is responsible for the production of uric acid. Uric acid can accumulate in joints, leading to symptoms of gout and other joint disorders.

A molybdenum intake of 0.008 to $0.022 \mathrm{mg} / \mathrm{kg}$-day can produce a mineral imbalance as a result of increased copper excretion (EPA, 1994a). Copper excretion is reported to double with molybdenum intake at the upper end of this range. Copper is an essential nutrient important in many metabolic pathways, including the synthesis and function of hemoglobin. A copper deficiency resulting from excess excretion will impair the oxygen-carrying capacity of the blood, and severe copper deficiencies can lead to hypochromic microcytic anemia. In humans, gout-like symptoms and joint deformities have been reported in regions of Russia where elevated molybdenum concentrations in soil, and the resulting increased molybdenum concentrations in food, lead to molybdenum intakes in the range of 0.14 to $0.21 \mathrm{mg} / \mathrm{kg}$-day. The EPA oral reference dose of $0.005 \mathrm{mg} / \mathrm{kg}$ day for molybdenum was derived from results of these studies (EPA, 1994a). An uncertainty factor of 30 was used for two reasons: to protect the sensitive human population and to use the lowest-observed-adverse-effect level (LOAEL) of $0.14 \mathrm{mg} / \mathrm{kg}$-day) rather than the preferred no-observed-adverse-effect level (NOAEL), which should be identified from a long-term study in a human population. Figure 5.5 summarizes the health effects of molybdenum as a function of dose.

\subsubsection{Sodium}

\section{Absorption}

Sodium is rapidly and fully absorbed from the gastrointestinal tract. The skin and lungs also absorb sodium rapidly, by simple diffusion and ion exchange (National Research Council, 1980). 

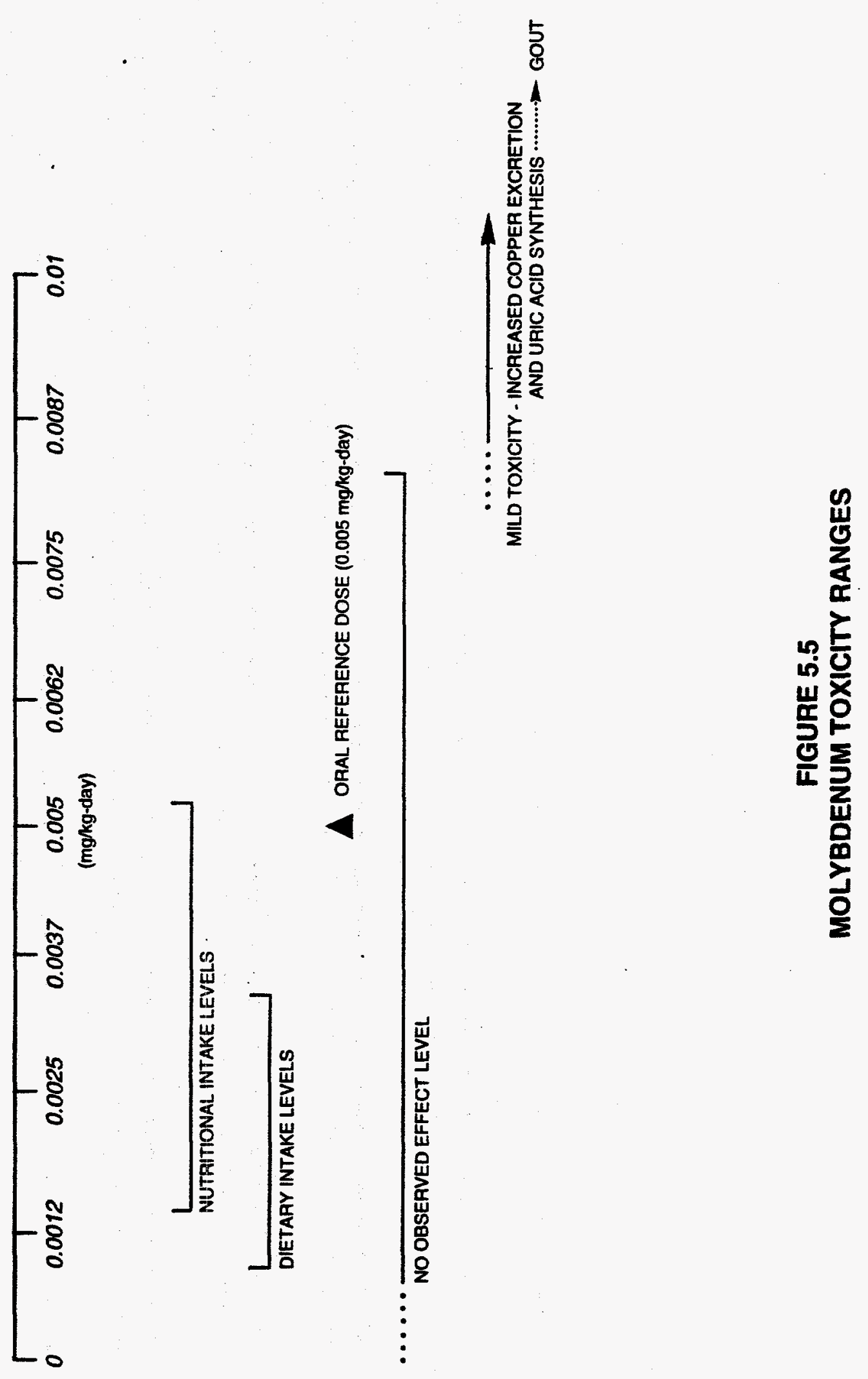


\section{Tissue accumulation and clearance}

Sodium is the major extracellular ion. The sodium ion is essential to the regulation of the acid-base balance and is an important contributor to extracellular osmolarity. It is an essential constituent in the electrophysiological functioning of cells and is required for impulse propagation in excitable tissues. Furthermore, sodium is essential for active nutrient transport, including the active transport of glucose across the intestinal mucosa. About 30 to 40 percent of the body's sodium is thought to be stored on the surfaces of the bone crystals, where it is easily recovered if blood sodium levels drop. Sodium is excreted mainly in urine, with appreciable amounts also excreted in feces, sweat, and tears (Venugopal and Luckey, 1978). Mammalian renal sodium excretion is a two-phase process involving glomerular filtration and reabsorption in proximal tubules; of about 600 grams of sodium involved in 24-hour glomerular filtration, approximately 99.5 percent is reabsorbed in human adults. A homeostatic mechanism for sodium functions at the renal excretory level.

\section{Environmental sources of sodium}

The total sodium intake is influenced mainly by the amount of salt (sodium chloride) added to food, the inherent salt content of the foods consumed, and the amount of other sodium salts in the diet and in medication. Sodium is a natural constituent of both vegetable and animal products in varying concentrations. Other sources of sodium are drinking water, cooking water, soft drinks, and alcoholic beverages.

At 2 months, infants consume approximately $300 \mathrm{mg}$ of sodium a day; at 12 months, approximately $1400 \mathrm{mg} /$ day. Human breast milk contains $161 \mathrm{mg} / \mathrm{L}$, and cow's milk contains approximately $483 \mathrm{mg} / \mathrm{L}$ (Carson et al., 1986).

No RDA is set for sodium. The National Research Council recommends limiting daily sodium intake to less than $2400 \mathrm{mg}$ (34 mg/kg-day); the American Heart Association recommends limiting dietary sodium intake to $3000 \mathrm{mg}$ daily. A healthy person requires about $115 \mathrm{mg}$ sodium daily $(1.6 \mathrm{mg} / \mathrm{kg}$-day), yet sodium dietary intake is estimated at 57 to $85 \mathrm{mg} / \mathrm{kg}$-day. However, dietary sodium intakes as high as $134 \mathrm{mg} / \mathrm{kg}$-day are reported (National Research Council, 1980).

The sodium content of drinking water is extremely variable. Analyses of water supply systems indicate sodium concentrations in 630 systems range from less than 1 to $402 \mathrm{mg} / \mathrm{L}$ (resulting in sodium intake from less than 0.03 to 11 $\mathrm{mg} / \mathrm{kg}$-dayl, with 42 percent greater than $20 \mathrm{mg} / \mathrm{L}$ and 3 percent over $200 \mathrm{mg} / \mathrm{L}$ (Carson et al., 1986). 


\section{Toxicity of sodium}

Symptoms of acute sodium chloride toxicity accompanied by visible edema may occur in healthy adult males with an intake as low as 35 to 40 grams of salt per day (200 to $223 \mathrm{mg} / \mathrm{kg}$-day, because sodium is 39 percent of the weight of sodium chloride) (Meneely and Battarbee, 1976). The mean lethal dose of sodium for humans is reportedly $3230 \mathrm{mg} / \mathrm{kg}$ (Venugopal and Luckey, 1978).

Epidemiological studies indicate that long-term, excessive sodium intake is one of many factors associated with hypertension in humans. A high sodium-topotassium ratio in the diet may be detrimental to persons susceptible to high blood pressure. Some adults, however, tolerate chronic intake above 40 grams of sodium chloride per day (equivalent to $223 \mathrm{mg} / \mathrm{kg}$-day) (Carson et al., 1986).

Research indicates that critical levels of sodium ingestion cause blood pressure to rise with age, leading to hypertension. Freis (1976) reports that with sodium intake below $227 \mathrm{mg} /$ day $(3 \mathrm{mg} / \mathrm{kg}$-day for a $70-\mathrm{kg}$ adult), hypertension was absent. In the range of 227 to $1591 \mathrm{mg} /$ day 13 to $23 \mathrm{mg} / \mathrm{kg}$-day for a $70-\mathrm{kg}$ adult), a few cases of hypertension may appear, while in the range of 1591 to $8000 \mathrm{mg} /$ day (23 to $114 \mathrm{mg} / \mathrm{kg}$-day for a $70-\mathrm{kg}$ adult), approximately 15 percent of adults exhibit hypertension. When sodium intake rises above $8000 \mathrm{mg} /$ day, hypertension may be found in about 30 percent of the population. Because sodium chloride is present in nearly all processed and packaged foods, limiting dietary intake is difficult. The average daily dietary intake in the United States often causes hypertensive effects.

Drinking water generally contains relatively low levels of sodium and therefore does not substantially contribute to the total intake unless sodium is at higherthan-average levels in the water supply. However, people on sodium-restricted diets can obtain a considerable portion of daily sodium from drinking water. Because the kidney is the major organ involved in regulating sodium balance, individuals with compromised kidney function may be placed on a low-sodium diet. Other individuals may be on low-sodium diets to control hypertension. Because of the high prevalence of such individuals in our society, the American Heart Association has proposed that public drinking water supplies in the United States adopt a standard of $20 \mathrm{mg} / \mathrm{L}$ sodium (Calabrese and Tuthill, 1977). This standard measure would limit the additional intake of sodium from drinking water to approximately $0.6 \mathrm{mg} / \mathrm{kg}$-day for a $70-\mathrm{kg}$ adult. Figure 5.6 summarizes the potential health effects of sodium as a function of dose.

\subsubsection{Sulfate}

\section{Absorption}

Sulfate absorption from the gastrointestinal tract is similar in humans and other animals. Generally, greater than 90 percent absorption is reported for sulfate doses below $150 \mathrm{mg} / \mathrm{kg}$, decreasing to 50 to 75 percent as the dose increases into the grams-per-kilogram range. 


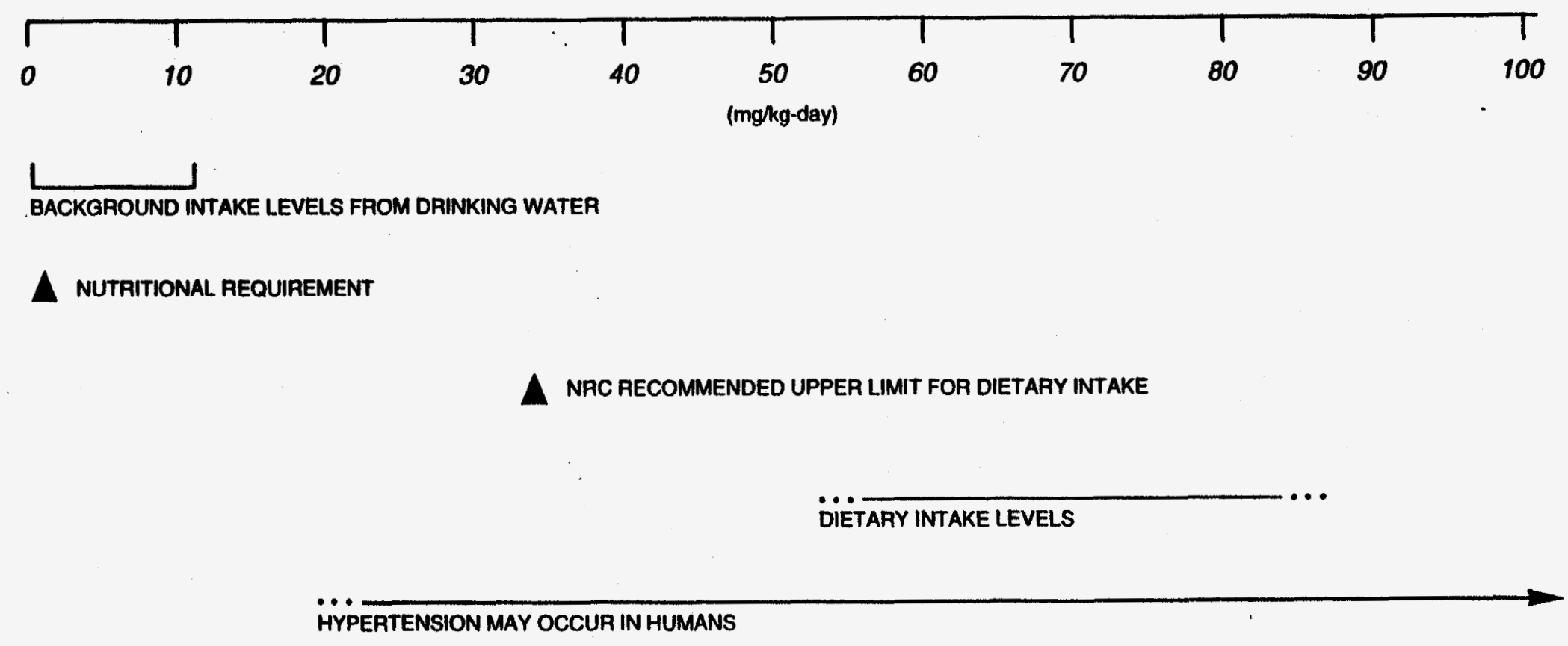

FIGURE 5.6

SODIUM TOXICITY RANGES

MAC: SITE/SLCBAASOD-GEN 


\section{Tissue accumulation and retention}

Ingesting high levels of sulfate results in transient increases in both blood and urine concentrations. Approximately 50 percent of a $75-\mathrm{mg} / \mathrm{kg}$ dose is excreted over 72 hours. The urinary excretion mechanism is transport-limited and can become saturated at high doses of sulfate. Excess sulfate is also excreted in feces in its inorganic form. To date, no data indicate that sulfate accumulates, even with chronic ingestion of above-normal levels. However, extremely high chronic doses have not been examined in humans.

Sulfate is used to biosynthesize collagen, cartilage, and dentin and to form sulfate esters of both endogenous compounds (such as lipids and steroids) and exogenous compounds (such as phenols). Sulfation is important in detoxication pathways because it increases the solubility of these compounds, enhancing their excretion in the urine. Exposure to high concentrations of compounds that are conjugated with sulfate and excreted can produce a transient decrease in plasma sulfate concentrations.

\section{Environmental sources of sulfate}

In 1978, drinking water sulfate concentrations in the western United States (EPA, 1992a) ranged from 0 to $820 \mathrm{mg} / \mathrm{L}$, with a mean concentration of $99 \mathrm{mg} / \mathrm{L}$. The EPA estimates a normal sulfate intake range of 0.00023 to $0.0064 \mathrm{mg} / \mathrm{kg}$-day from air and up to $2.9 \mathrm{mg} / \mathrm{kg}$-day from drinking water in the western United States. Estimates on sulfate intake from food are not available.

\section{Toxicity of sulfate}

The acute and chronic effects of sulfate toxicity differ more in severity than in symptoms or mechanisms. Therefore, this discussion will combine acute and chronic toxicity. As discussed above, no data indicate sulfate bioaccumulation with chronic exposure. Sulfate salts of magnesium and sodium are used medicinally as cathartics. High concentrations of unabsorbed sulfate salts in the gut can pull large amounts of water into the gut, greatly increasing the normal volume of feces. This action is also the basis of sulfate's toxic effects.

Toxicity in humans is primarily manifested in diarrhea; the severity of the diarrhea is dose-dependent. Chronic sulfate ingestion can result in persistent diarrhea, leading to ionic imbalance and dehydration similar to that seen with extremely high acute doses. Serious gastroenteritis is reported in some infants and adults drinking water containing 400 to $1000 \mathrm{mg} / \mathrm{L}$ sulfate (EPA, 1992a). When drinking water is contaminated with sulfate, the taste of the water may make it unpalatable and reduce consumption. However, this is not necessarily the case. In regions with high sulfate concentrations in the drinking water (such as Saskatchewan), residents adapt to the taste and find the water palatable (EPA, 1992a). A lower water intake could compound the dehydration effects of the diarrhea. Extreme dehydration can lead to death. Infants appear to be the most susceptible population for sulfate-induced diarrhea. Also, some data 
indicate that diabetic and elderly populations with compromised kidney function may be more sensitive than healthy adults to the effects of sulfates (EPA, 1992a). Figure 5.7 summarizes these health effects as a function of dose.

Sulfate toxicity data are based primarily on epidemiologic studies of human adults and infants who report to hospitals with symptoms of sulfate exposure. In most cases, exposure doses have been back-calculated from sampling their drinking water. Therefore, these data do not represent well-controlled studies with readily defined dosage ranges.

\subsubsection{Uranium}

The uranium that occurs naturally at UMTRA Project sites consists of three radioactive isotopes: uranium-234, uranium-235, and uranium-238. More than 99 percent of natural uranium occurs in the form of uranium-238 (Cothern and Lappenbusch, 1983). Uranium-238 undergoes radioactive decay by emitting alpha particles to form uranium-234, thorium-230, radium-226, radon-222, polonium210 , lead-210, and other radioisotopes. Figure 5.8 summarizes the radioactive decay chain of uranium-238 and uranium-234. Because all natural uranium isotopes are radioactive, the hazards of a high uranium intake are from both its chemical toxicity and its potential radiological damage. The chemical toxicity of natural uranium is discussed here; the carcinogenic potential associated with exposure to radioactive isotopes of natural uranium is discussed in Section 5.3.

\section{Absorption}

Uranium absorption in the gastrointestinal tract depends on the solubility of the uranium compounds. The hexavalent uranium compounds, especially the uranyl salts, are water soluble, while tetravalent compounds generally are not (Weigel, 1983). However, only a small fraction of the soluble compounds is absorbed. Wrenn et al. (1985) have determined human gastrointestinal absorption rates of 0.76 to 7.8 percent.

Uranium may absorb through the skin when applied in concentrated solutions (the concentration level was not reported). The extent of absorption appears to be dose-dependent.

\section{Tissue accumulation and clearance}

In humans exposed to background levels of uranium, the highest concentrations were found in the bones, muscles, lungs, liver, and kidneys (Fisenne et al., 1988). Uranium retention in bone consists of a short retention half-time of 20 days, followed by a long retention half-time of $\mathbf{5 0 0 0}$ days for the remainder (Tracy et al., 1992).

In body fluids, uranium tends to convert into water-soluble hexavalent uranium (Berlin and Rudell, 1986). Approximately 60 percent of the uranium in plasma 


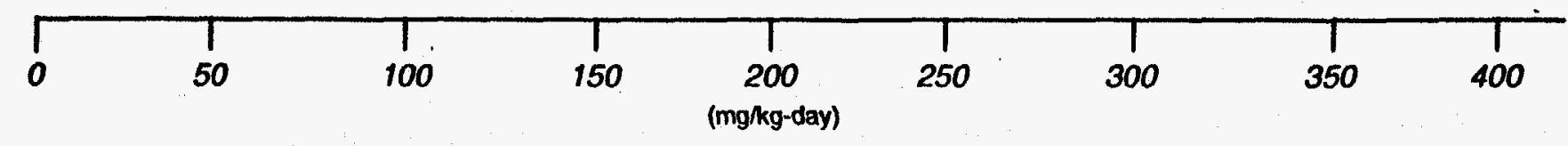

u

BACKGROUND INTAKE LEVELS

능..․․

NO ÖBSERVED EFFECTS

MiLD TOXICITY RANGING FROM LAXATIVE EFFECT (ADULTS) TO DIARRHEA IN INFANTS

SËVERE TOXICITY - PERSISTENT INFANT DIARRHEA LEADING TO DEHYDRATION

FIGURE 5.7

SULFATE TOXICITY RANGES 


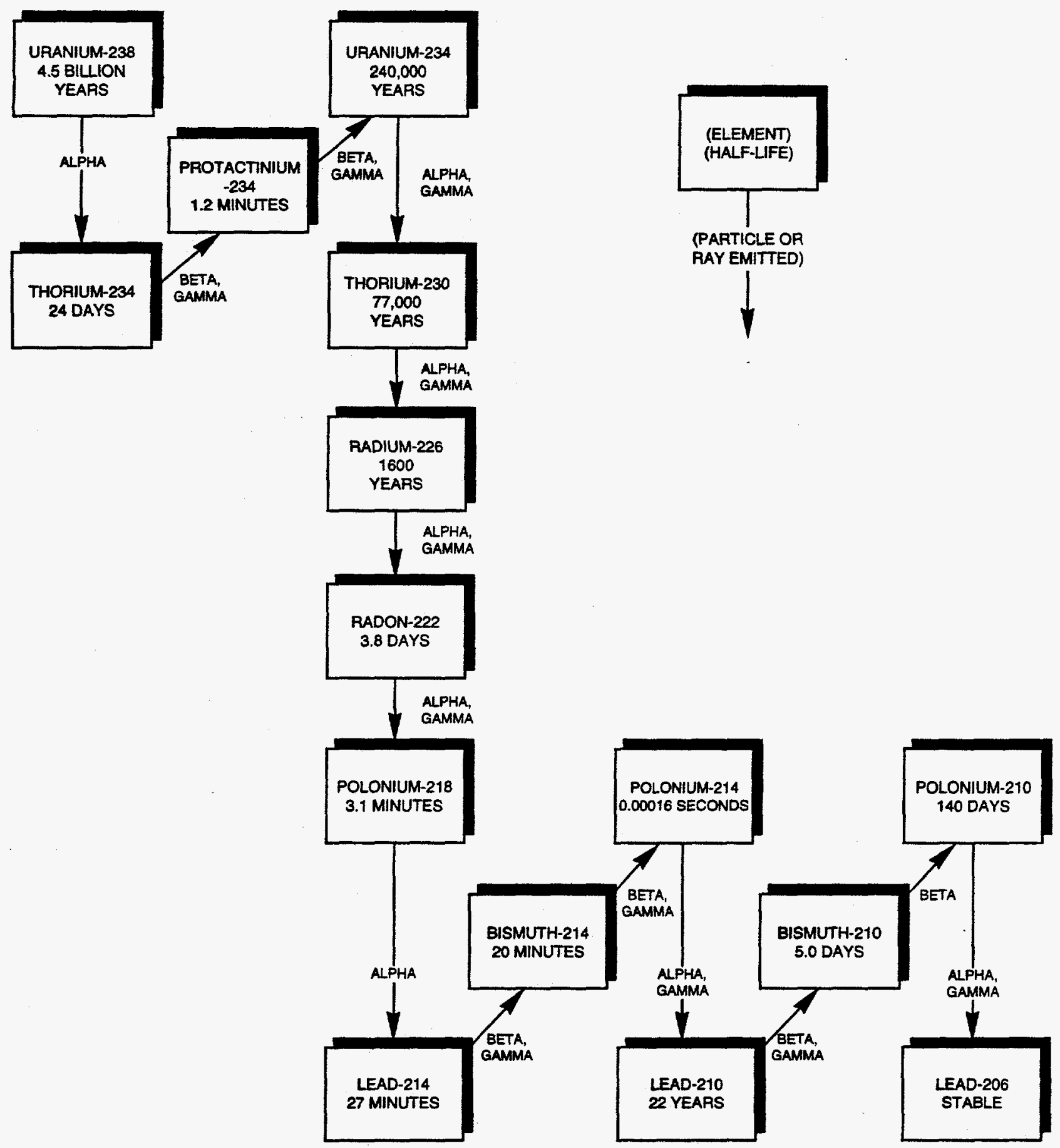

MODIFIED FROM SHLEIEN, 1992.

FIGURE 5.8

HALF-LIVES AND EMISSIONS FROM DECAY CHAIN OF URANIUM-238 
complexes with low-molecular-weight anions (e.g., bicarbonates, citrates), while the remaining 40 percent binds to the plasma protein transferring (Stevens et al., 1980l. Following oral exposure to uranium, humans excrete more than 90 percent of the dose in the feces. Of the small percent that is absorbed (typically less than 5 percent), animal studies show that approximately 60 percent is excreted through the urine within 24 hours, whereas the remainder is distributed to the skeleton and soft tissue; 98 percent of that amount is excreted within 7 days (Ballou et al., 1986; Leach et al., 1984; Sullivan et al., 1986). A small portion of the absorbed uranium is retained for a longer period.

\section{Environmental sources of uranium}

Uranium is a ubiquitous element, present in the earth's crust at approximately $4 \mathrm{ppm}$. Uranium concentrations in ground water and surface water average 1 picocurie per liter (pCi/L) and $3 \mathrm{pCi} / \mathrm{L}$, respectively (NCRP, 1984). The extent of uptake from the soil into plant tissues depends on the plant species and the depth of its root system (Berlin and Rudell, 1986). Tracy et al. (1983) report plant uranium concentrations averaging $0.075 \mathrm{mg} / \mathrm{kg}$ of fresh plant material.

The main dietary source of natural uranium for the general population is food le.g., potatoes, grains, meat, and fresh fish) that may contain uranium concentrations between 10 and $100 \mathrm{mg} / \mathrm{kg}$ (Prister, 1969). The total uranium dietary intake from consuming average foods is approximately 1 microgram $(\mu \mathrm{g}) /$ day; approximately 20 to 50 percent of that total can come from drinking water. Cereals and vegetables, particularly root crops, probably contribute most to daily uranium intake (Berlin and Rudell, 1986).

\section{Toxicity of uranium}

No human deaths are reported that are definitely attributable to uranium ingestion; therefore, no lethal dose has been determined for humans. Lethal doses of uranium $\left(L D_{50,23}\right)$ are reported to be $14 \mathrm{mg} / \mathrm{kg}$-day following 23-day oral exposure, depending on the solubility of the uranium compound tested (higher solubility compounds have greater toxicity), exposure route, and animal species. High doses of uranium cause complete kidney and respiratory failure.

No chronic toxic effects are reported in humans following oral exposure to uranium. Data from populations occupationally exposed to high concentrations of uranium compounds through inhalation and information from studies on experimental animals indicate that the critical organ for chronic uranium toxicity is the proximal tubule of the kidney (Friberg et al., 1986). In humans, chemical injury reveals itself by increased catalase excretion in urine and proteinuria. Doseresponse data for the toxic effects of uranium on the human kidney are limited.

The lowest dose of uranyl nitrate that caused moderate renal damage was given to rabbits in diet at $2.8 \mathrm{mg} / \mathrm{kg}$-day (Maynard and Hodge, 1949). The EPA oral reference dose of $0.003 \mathrm{mg} / \mathrm{kg}$-day was derived based on this study (EPA, 
1994a). Figure 5.9 summarizes the health effects of uranium as a function of dose.

\subsection{CONTAMINANT INTERACTIONS}

Although some information is available on potential interactions between the contaminants found at UMTRA Project sites, discussions of potential interactions generally can be presented only qualitatively. In addition to individual physiological variables that can affect toxicity, interaction uncertainties also can be expected because exposure concentrations may be different than the concentrations tested experimentally. In addition, some ground water constituents may be present in sufficient quantities to modify predicted toxicities even though they are not considered contaminants of concern to human health. Therefore, the interactions described below should be recognized as factors that can influence the predicted toxicity, although the precise nature and magnitude of that influence cannot be determined.

A primary concern at the Salt Lake City site is the potential for interactions between metals. Interactions between several similar metals can alter the predicted absorption, distribution in the body, metabolism, toxicity, or clearance of a metal of interest.

For example, manganese absorption can be considerably altered under conditions of high calcium or iron or by a low-protein diet (Elinder, 1986). Manganese absorption from the intestine may considerably decrease in the presence of high dietary iron, leading to decreased manganese toxicity (DHHS, 1992). Conversely, high levels of manganese lead to decreased iron absorption. Short-term effects of this type are probably the result of kinetic competition between iron and manganese for a limited number of binding sites on intestinal transport enzymes, while longer-term effects of excess iron probably are due to adaptive changes in the level of intestinal transport capacity. Additionally, a physiological interaction between manganese and the metal-binding protein metallothionein can occur (DHHS, 1992; Casarett and Doull, 1991). Manganese can induce metallothionein synthesis and the formation of a metallothionein-manganese complex would enhance manganese excretion, decreasing its toxicity.

Because calcium, barium, magnesium, and strontium are competitive with respect to their absorptive sites, an excess of any of these elements may partially inhibit the absorption of others. Calcium salts also decrease the gastrointestinal absorption of fluoride (National Research Council, 1980). In addition, magnesium decreases fluoride absorption somewhat less effectively than calcium. However, molybdenum may promote fluoride retention and thereby intensify the toxic response (Casarett and Doull, 1991).

In animal studies, iron status affected the gastrointestinal absorption of uranium; however, the reported results were inconclusive (EPA, 1989b). No other 


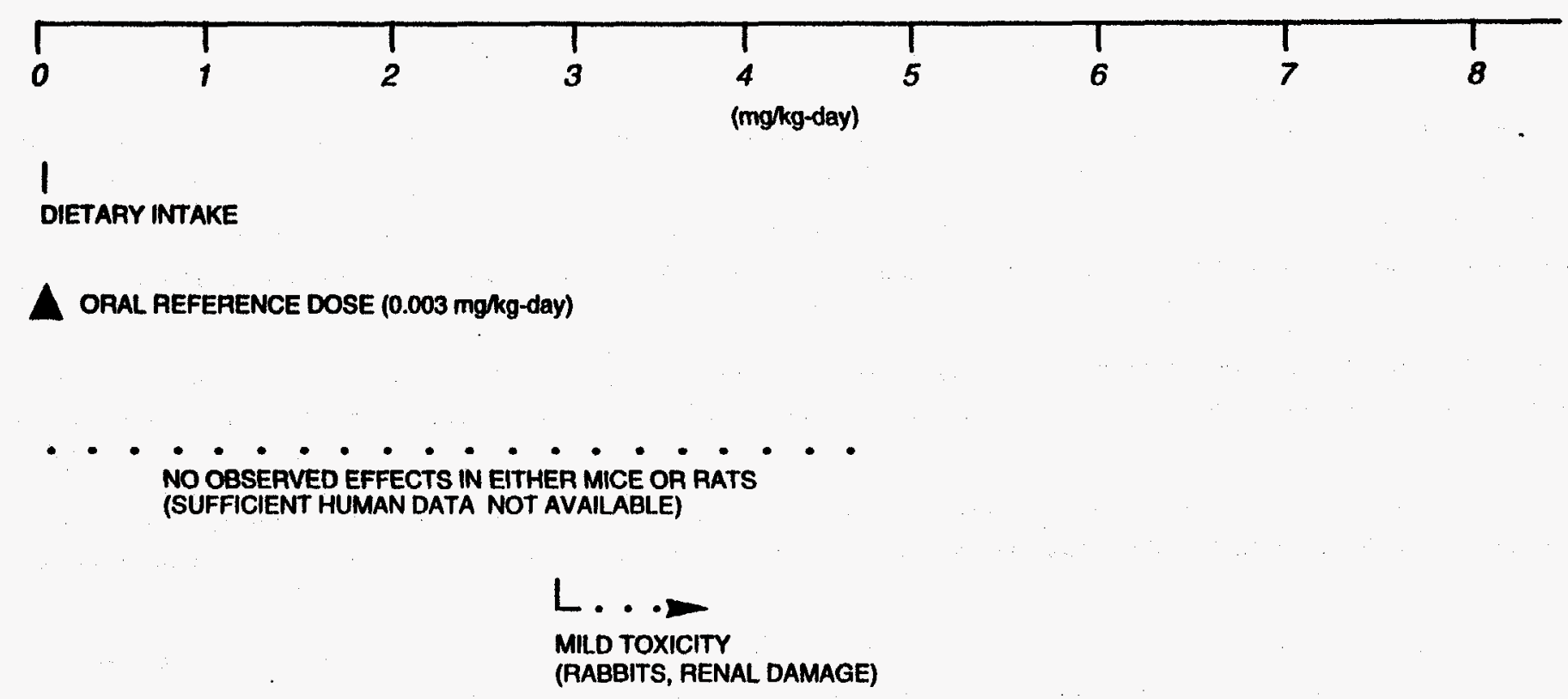

FIGURE 5.9

URANIUM TOXICITY RANGES 
information has been found on the interactions of uranium with other metals. However, the common target organ suggests uranium, manganese, and molybdenum interact to produce kidney toxicity.

Sulfate also interacts in a complex manner with molybdenum and copper. Sulfate reduces molybdenum accumulation by competing for protein carriers and enhances its excretion by inhibiting tubular reabsorption. Molybdenum can produce a functional copper deficiency. The antagonism of molybdenum to copper is augmented by sulfate. Ruminants seem to be the most susceptible species to imbalances between molybdenum, copper, and sulfate. In ruminants, copper sulfate can protect against molybdenum toxicity. It has also been suggested that sulfide (a reduced form of sulfate) can displace molybdate in the body. In laboratory animal models, molybdenum toxicity is more pronounced when dietary copper intake is low (EPA, 1994a).

Because ingesting high levels of sulfate and magnesium produces diarrhea that leads to dehydration, and ingesting of high levels of sodium and chloride leads to water retention, a physiological interaction might be expected to occur with simultaneous ingestion of all of them. However, available data do not predict the net effects of chronic ingestion of sulfate and sodium at high concentrations. Although high-concentration sodium chloride solutions are used to treat diarrheainduced hyponatremia and hypochloremic metabolic alkalosis, the electrolyte concentrations in these solutions are physiologically balanced. Disproportionately high sodium and chloride levels could intensify the electrolyte loss produced by severe diarrhea.

In addition, diarrhea-induced dehydration may cause contaminants excreted in urine to concentrate in the kidney. Thus, diarrhea-induced dehydration may enhance the predicted toxicities of these contaminants.

\subsection{CONTAMINANT RISK FACTORS}

The EPA Office of Research and Development has calculated acceptable intake values, or RfDs, for long-term (chronic) exposure to noncarcinogens. These values are estimates of route-specific exposure levels that are not expected to cause adverse effects when exposure occurs for a meaningful portion of a lifetime. The RfDs include safety factors to account for uncertainties associated with limitations of the toxicological data base. These safety factors include extrapolating results from animal studies to humans and accounting for response variabilities in sensitive individuals. These values are updated quarterly and are published in the Health Effects Assessment Summary Tables (HEAST) (EPA, 1994b). Following more stringent review, they are published through the EPA's IRIS data base. Table 5.1 summarizes the most recent oral RfDs for the noncarcinogenic contaminants of concern.

The EPA currently classifies all radionuclides as Group A, or known human carcinogens, based on their property of emitting ionizing radiation and on the evidence provided by epidemiological studies of radiation-induced cancer in 


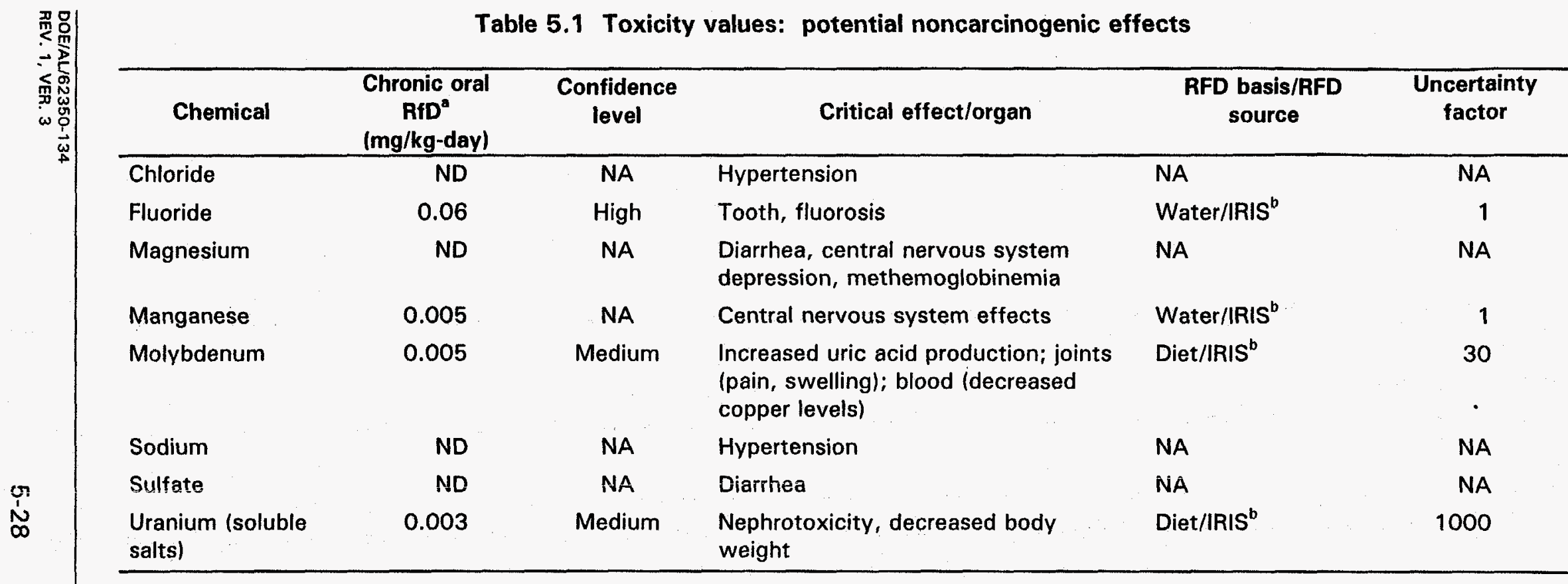

${ }^{a}$ These doses are adopted as subchronic oral RfDs with the exception of uranium.

'From EPA (1994a).

'From EPA (1994b).

NA - not applicable.

ND - not determined. 
humans. At sufficiently high doses, ionizing radiation acts as a complete carcinogen (both initiator and promoter), capable of increasing the probability of cancer development. However, the actual risk is difficult to estimate, particularly for the low doses and dose rates encountered in the environment. Most reliable data were obtained under conditions of high doses delivered acutely. It is not clear whether cancer risks at lower doses are dose-proportional (i.e., the linear doseresponse hypothesis) or whether the risk is greatly reduced at low doses and rates (i.e., the threshold hypothesis). A conservative assumption rejects the threshold hypothesis and assumes that any dose adds to the risk of cancer.

Risk factors published in HEAST and IRIS correlate the intake of carcinogens over a lifetime with the increased excess cancer risk from that exposure. Table 5.2 gives the most recent cancer slope factors for the uranium-234 and -238 radioactive decay series.

Table 5.2 Toxicity values: carcinogenic effects

\begin{tabular}{|c|c|c|c|c|}
\hline Parameter & $\begin{array}{l}\text { Oral slope } \\
{\text { factor }(\mathrm{SF})^{\mathrm{a}}}^{(\mathrm{pCi})^{-1}}\end{array}$ & $\begin{array}{l}\text { Weight of } \\
\text { evidence } \\
\text { classification }\end{array}$ & Type of cancer & $\begin{array}{l}\text { Slope factor } \\
\text { basis/slope } \\
\text { factor source }^{b}\end{array}$ \\
\hline Lead- $210^{c}$ & $1.01 \mathrm{E}-09$ & $A$ & Bone & HEAST \\
\hline Polonium-210 & $3.26 E-10$ & A & Liver, kidney, spleen & HEAST \\
\hline Radium-226 ${ }^{\mathrm{c}}$ & $2.96 \mathrm{E}-10$ & A & Bone & HEAST \\
\hline Thorium-230 & $3.75 E-11$ & $A$ & d & HEAST \\
\hline Uranium-238 & $6.20 \mathrm{E}-11$ & A & e & HEAST \\
\hline Uranium-234 & $4.44 \mathrm{E}-11$ & A & e & HEAST \\
\hline
\end{tabular}

${ }^{a}$ For each individual radionuclide listed, oral slope factors correspond to the risks per unit intake (risk/pCi) for that radionuclide, except as noted.

${ }^{\mathrm{b}}$ From EPA (1994b).

'Oral slope factor includes the contributions from short-lived decay products, assuming equal activity concentrations (i.e., secular equilibrium) with the principal nuclide in the environment. ${ }^{d}$ Target organ systems have not been identified for oral exposure to thorium.

e No human or animal studies have shown a definite association between oral exposure to uranium and development of cancer.

A - Known human carcinogen.

HEAST - Health Effects Assessment Summary Tables 


\subsection{HUMAN HEALTH RISK EVALUATION}

Health risks to an individual or population are evaluated by combining the results of both the exposure and toxicity assessments. As discussed in Section 5.0, potential adverse health effects and their severity depend on the amount of the contaminant an individual takes into his or her body. At lower levels, many contaminants associated with uranium processing are beneficial to health, because they are essential nutrients. At higher levels, these same elements can cause adverse health effects. Also, some individuals may be more sensitive to a given level of exposure than others.

\subsection{POTENTIAL NONCARCINOGENIC HEALTH EFFECTS}

The results from the exposure assessment showing either the highest intake-tobody-weight ratios (i.e., highest doses) or the toxicologically most sensitive group are used here to evaluate the potential health effects of noncarcinogens. For chloride, fluoride, magnesium, manganese, molybdenum, sodium, and uranium, the highest intake-per-body-weight group is children 1 to 10 years old. Infants are used to evaluate the health risks of sulfate exposure because they are the most toxicologically sensitive population.

Exposure to sulfate presents the most important health risk associated with the contaminated ground water at the Vitro site. As can be seen in Figure 6.1, if ground water were used for drinking water, more than 70 percent of the expected exposures would be in the range of severe diarrhea in infants, which can lead to dehydration. However, these high-sulfate concentrations may cause the water to be unpalatable to infants, thus reducing their exposure.

Because the predicted sulfate toxicity from drinking water is so severe, and because this is the only exposure pathway for infants, the additive contribution from other sources would not alter the interpretation of health risks. Therefore, the contributions from other sources will not be evaluated at this time.

Note also that the exposure distribution for infants is based on tap water intake rates across a population that includes breast-fed and canned-formula-fed infants. Those infants consuming powdered formula reconstituted with well water would be in the upper percentiles of this exposure distribution and could be at higher risk of severe diarrhea. Further, these effects could be expected even after very short-term exposures.

In addition to sulfate-induced diarrhea, magnesium alone could cause diarrhea. More than 90 percent of the predicted range of children exposures to magnesium could be associated with mild diarrhea (Figure 6.2).

Infants exposed to magnesium from the drinking water ingestion route would have about 5 times the exposures of children. Thus, expected magnesium toxicity would be more serious in infants than in children. Simultaneous 


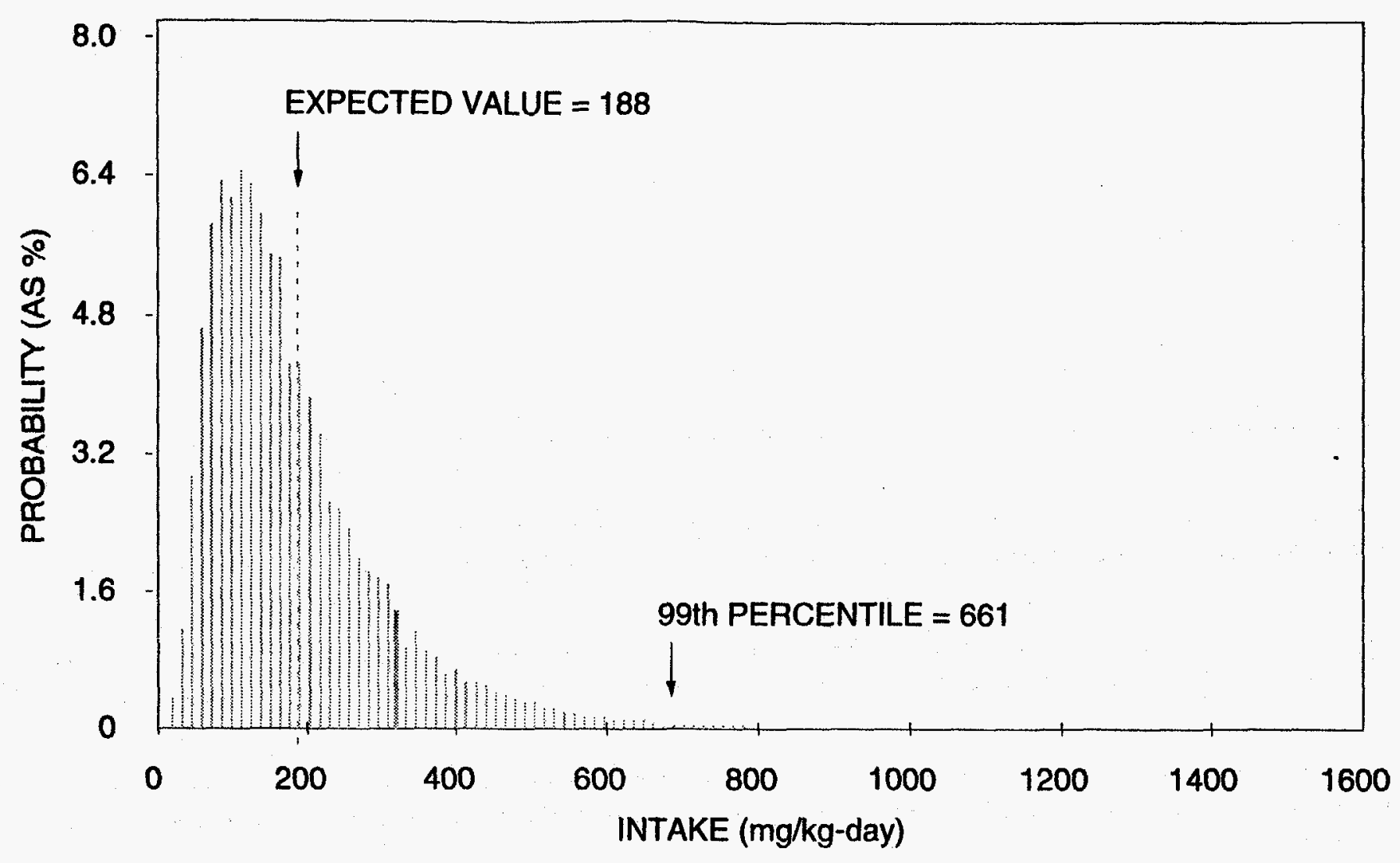

\section{U BACKGROUND INTAKE LEVEL}

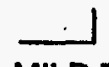

MILD TOXICITY RANGING FROM LAXATIVE EFFECT (ADULTS) TO DIARRHEA IN INFANTS

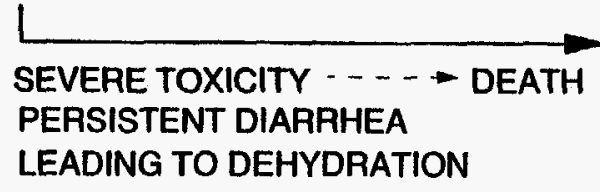

NOTE: SEVERE TOXIC EFFECTS MANIFESTED AS PERSISTENT DIARAHEA LEADING TO DEHYDRATION WOULD RESULT FROM THE MAJORITY OF PREDICTED EXPOSURES.

FIGURE 6.1

HEALTH EFFECTS OF POTENTIAL SULFATE EXPOSURE RANGES FOR INFANTS

SALT LAKE CITY, UTAH, SITE 

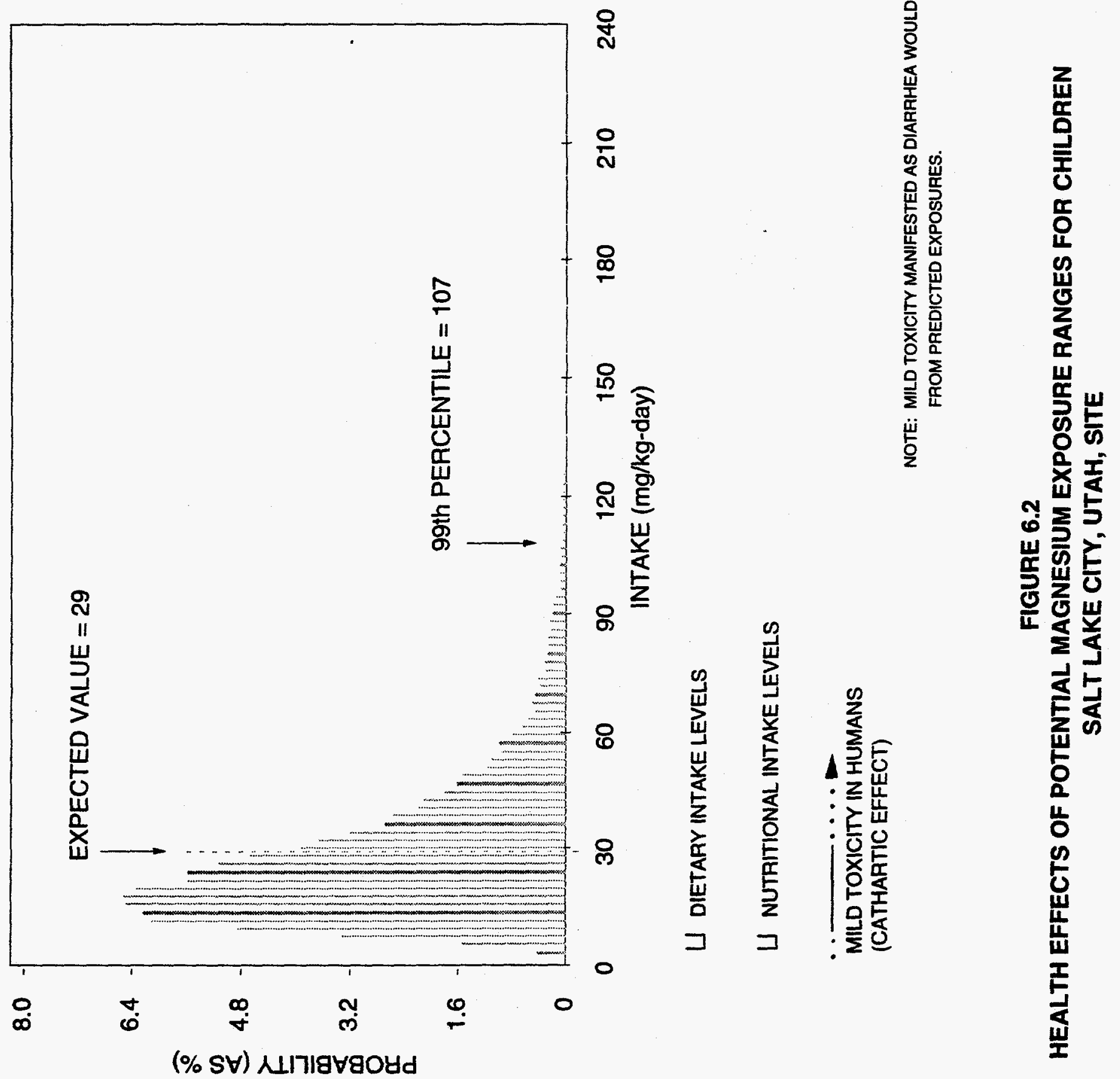
exposure to magnesium and sulfate in drinking water could augment the severity of sulfate-induced diarrhea. When renal impairment exists and magnesium excretion is impaired, magnesium exposure also could induce symptoms of central nervous system depression, such as sleepiness, confusion, and muscle weakness.

Chronic sodium exposure could be associated with the development of hypertension in children as well as in adults. As can be seen in Figure 6.3, 97 percent of the exposure distribution for sodium is above the threshold level of hypertension in humans. In addition, chloride exposure may contribute to the development of hypertension. About 90 percent of the exposure distribution for chloride alone may be associated with hypertension in sensitive individuals, although some uncertainty is associated with these literature data (Figure 6.4). Renal insufficiency would augment this health effect. Although solutions with physiologically balanced electrolyte concentrations containing high levels of sodium chloride have been used to alleviate diarrhea-induced hyponatremia, it is not possible to predict the net effect of simultaneous chronic ingestion of sodium chloride, sulfate, and magnesium at high concentrations without balanced electrolytes.

More than 70 percent of the exposure distribution for manganese (Figure 6.5) falls above the threshold level of mild neurological symptoms, and 85 percent of this distribution is above the EPA RfD (RfD of $0.005 \mathrm{mg} / \mathrm{kg}$-day) derived from drinking water consumption studies. As discussed in Section 5.1.4, infants may be more sensitive to manganese toxicity than children and adults. Therefore, toxic effects may appear in infants at levels lower than those in children. However, insufficient data exist to support a quantitative analysis.

More than 90 percent of the fluoride intake distribution falls above the threshold level of the cosmetic dental mottling in children (Figure 6.6). About 40 percent of this distribution is within the exposure range associated with dental fluorosis recognized as a pathology. About 60 percent of this distribution is above the acceptable intake level recommended by the EPA (RfD of $0.06 \mathrm{mg} / \mathrm{kg}$-day). The remaining portion of the exposure distribution falls into the range of the NOAEL for dental fluorosis. Modeling long-term adult exposure to fluoride could associate less than 1 percent of the predicted exposure level with the development of skeletal fluorosis in this age group.

The entire exposure distribution for molybdenum (Figure 6.7), is above the EPA RfD (RfD of $0.005 \mathrm{mg} / \mathrm{kg}$-day). About 30 percent of the estimated intake falls above the threshold level of mild toxicity, which could manifest as copper deficiency. Gout could result from increased production of uric acid.

The entire exposure distribution for uranium falls within the NOAEL range (Figure 6.8). However, almost 90 percent of the exposure distribution falls above the EPA acceptable intake level (RfD of $0.003 \mathrm{mg} / \mathrm{kg}$-day). This apparent discrepancy occurs largely because the toxicological data base is incomplete. 


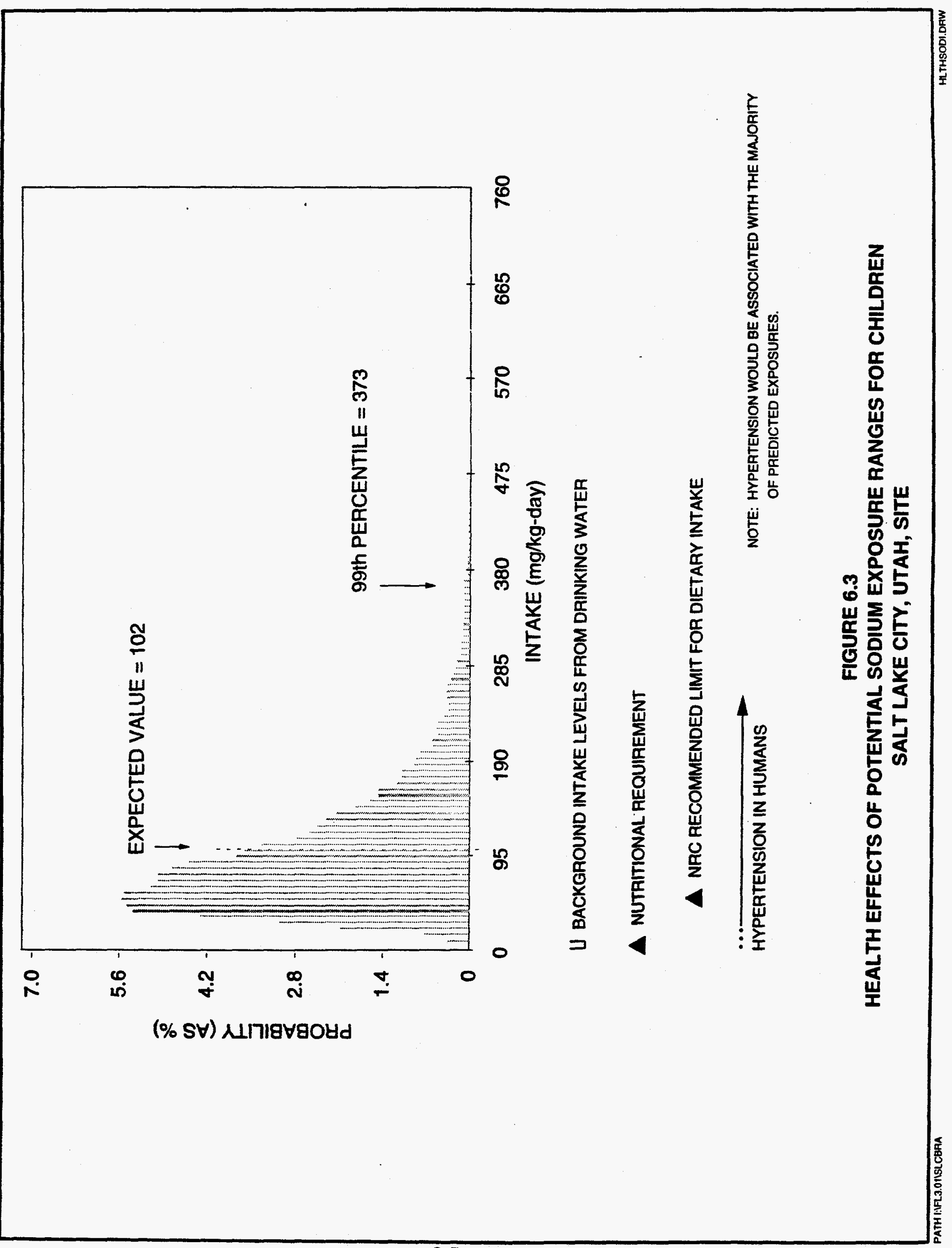




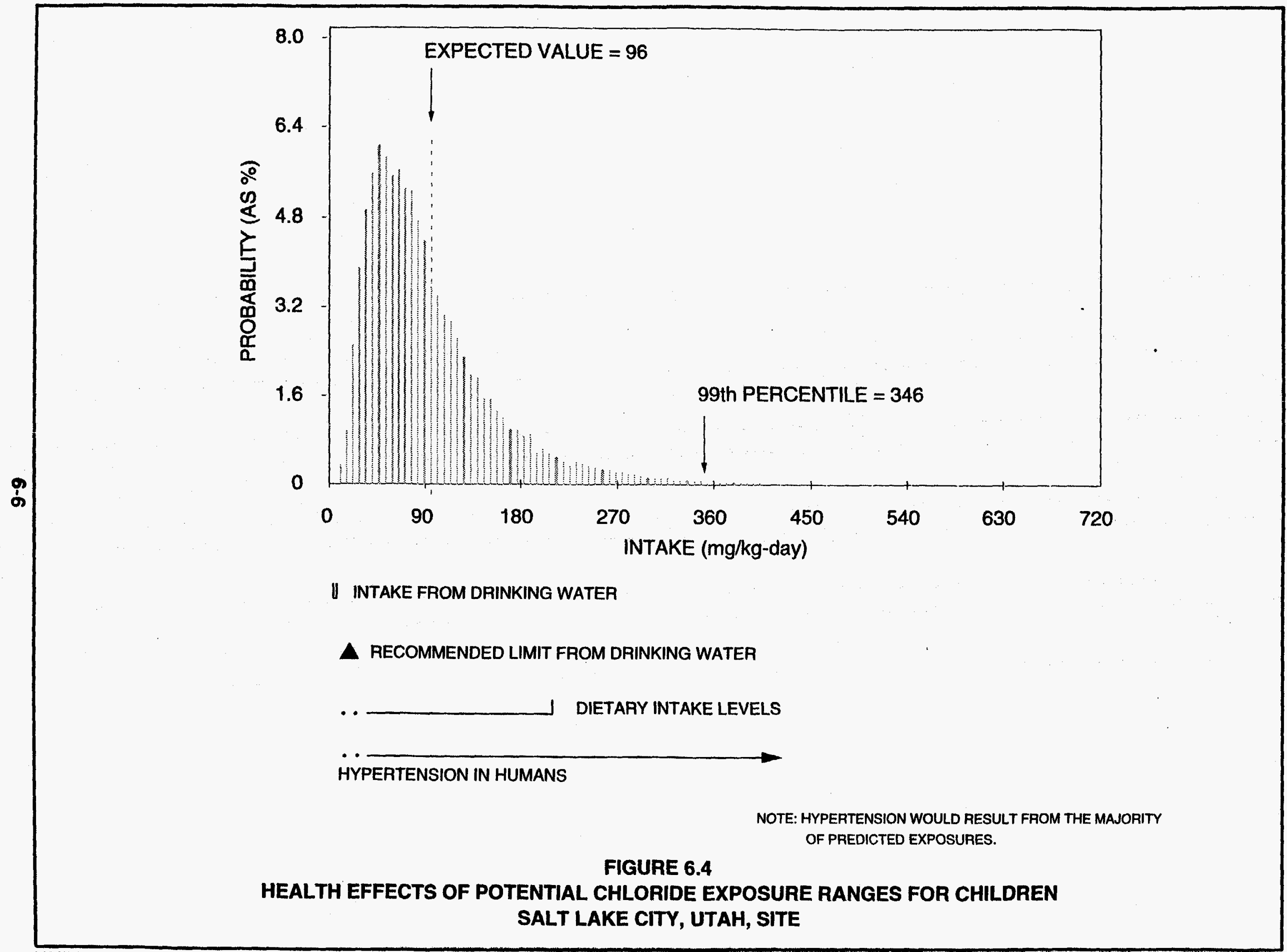




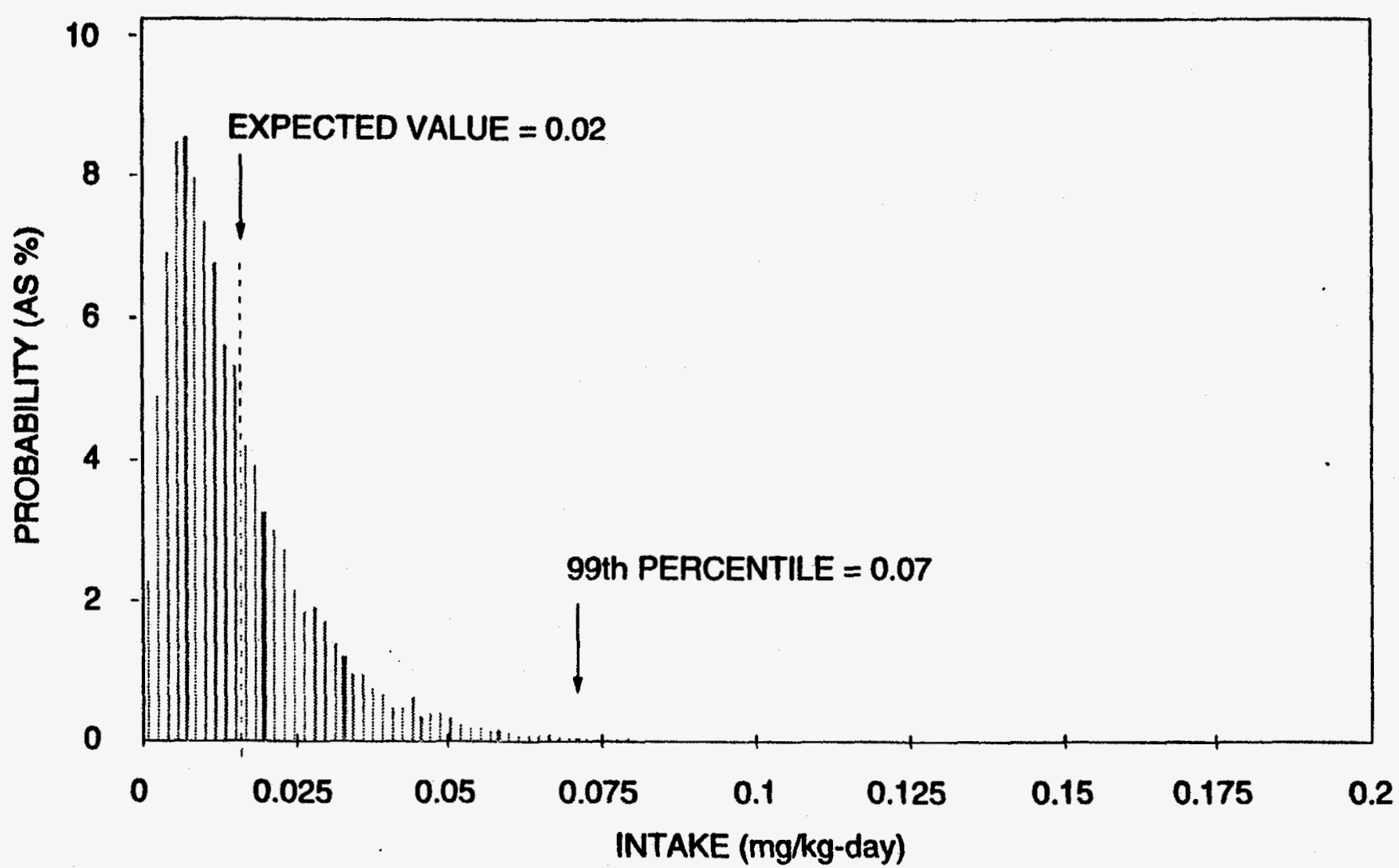

BACKGROUND DRINKING WATER INTAKE

DIETARY INTAKE LEVELS FROM FOOD

$\triangle$ ORAL REFERENCE DOSE, DRINKING WATER (0.005 mg/kg-day)

$$
\text { NEUURLOGICAL SYMPTOMS }
$$

PARKINSON-LIKE EFFECT

NOTE: NEUROLOGICAL SYMPTOMS WOULD BE ASSOCIATED WITH THE

FIGURE 6.5 MAJORITY OF PAEDICTED EXPOSURES.

HEALTH EFFECTS OF POTENTIAL MANGANESE EXPOSURE RANGES FOR CHILDREN

SALT LAKE CITY, UTAH, SITE 


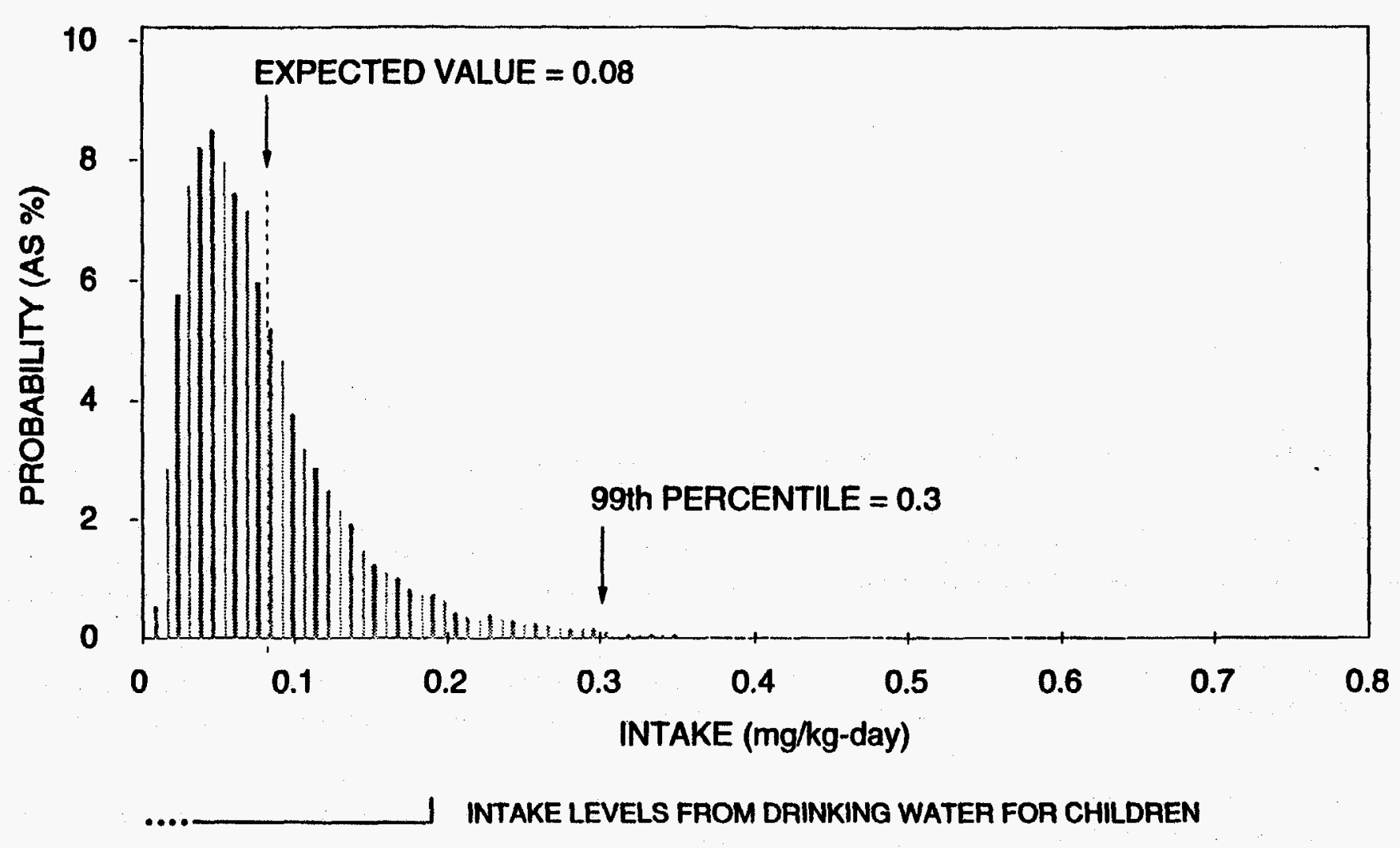

$\triangle$ ORAL REFERENCE DOSE, FOOD AND DRINKING WATER (0.06 mg/kg-day)

L. .

NO OBSERVABLE EFFECT LEVEL FOR DENTAL FLUOROSIS IN CHILDREN

...... DENTAL MOTTLING AND CHANGES IN TOOTH STRUCTURE IN CHILDREN

INCREASING DENTAL FLUOROSIS

......... NO OBSERVABLE EFFECT LEVEL FOR SKELETAL FLUOROSIS IN ADULTS

CRIPPLING SKELETAL FLUOROSIS IN ADULTS

NOTE: 90\% OF THE EXPOSURES IN CHILDREN WOULD BE ASSOCIATED

FIGURE 6.6 WITH DENTAL FLUOHOSIS OF DIFFERENT DEGREES OF SEVERITY.

HEALTH EFFECTS OF POTENTIAL FLUORIDE EXPOSURE RANGES FOR CHILDREN

SALT LAKE CITY, UTAH, SITE 

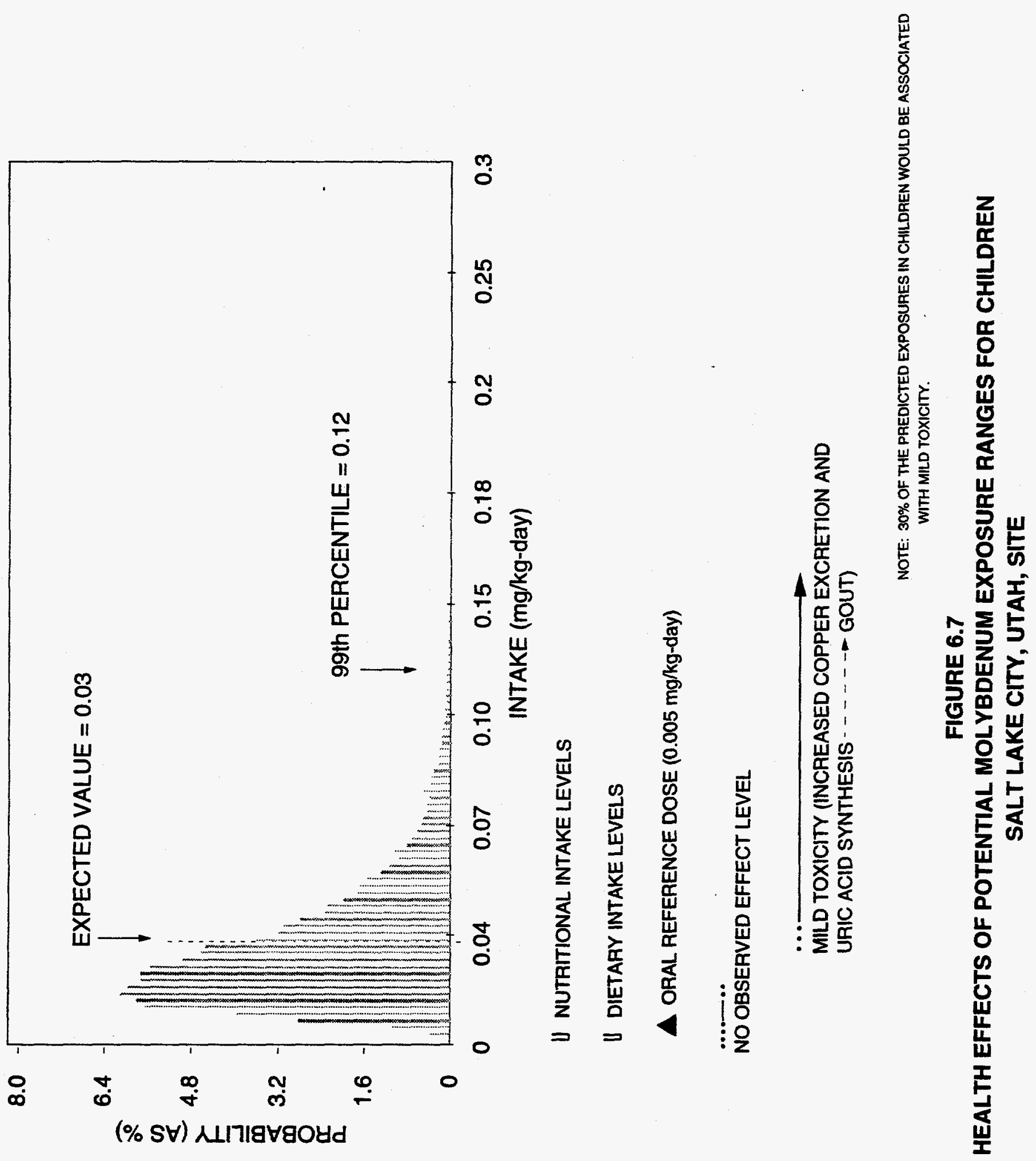


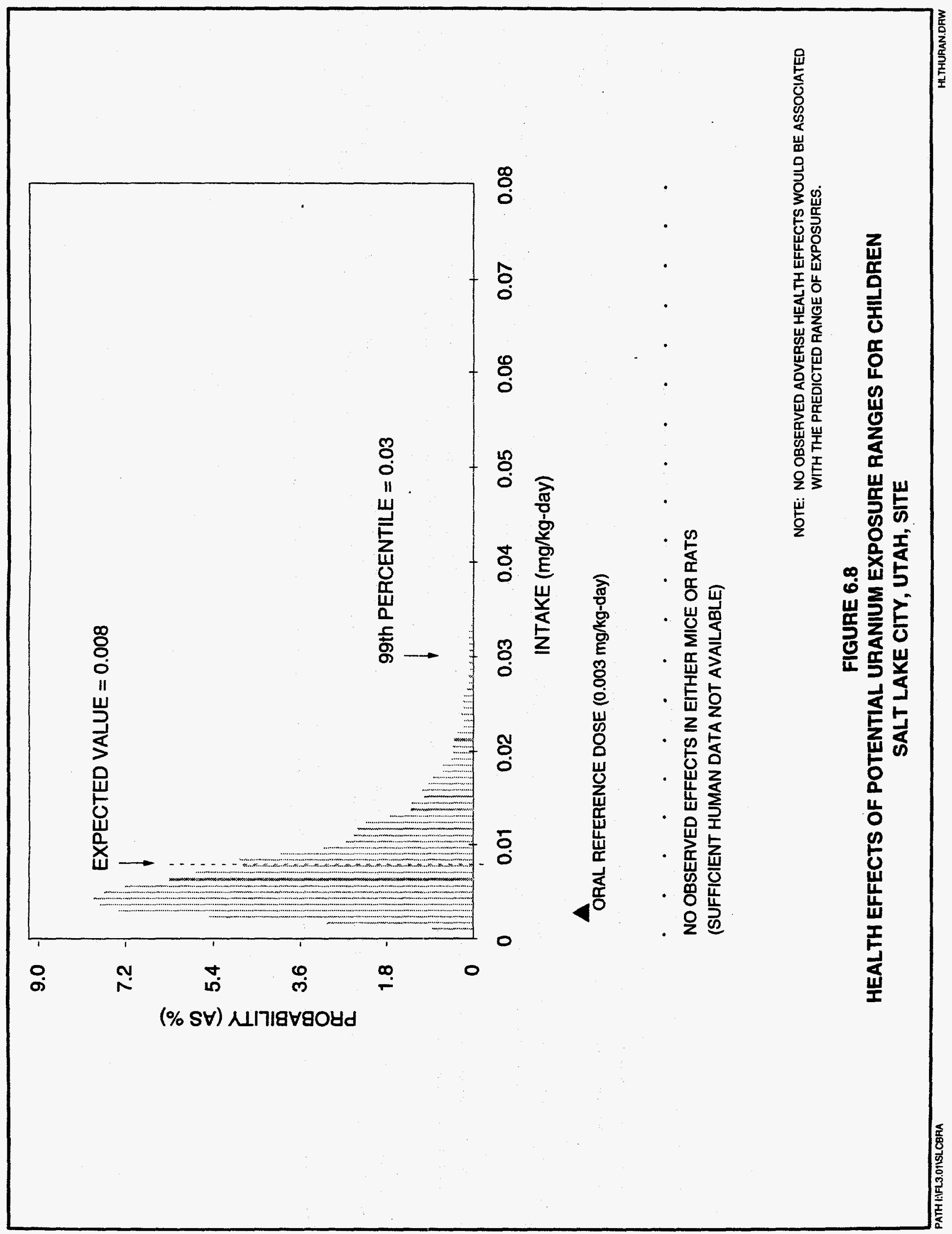


EPA takes this uncertainty into account by lowering the acceptable intake levels (RfDs). Although these low intake levels have not been associated with adverse health effects in humans or test animals, it is important that most of the exposure distribution falls above this RfD criterion.

Diarrhea-induced dehydration may lead to increased concentration of the contaminants in the kidney, enhancing the predicted toxicity from chemical exposures to magnesium, sodium, and most nephrotoxic metals.

The potential exposure contribution from other pathways, including produce ingestion, could not be estimated with current data. The UMTRA Project is conducting additional studies and the results will be used to better characterize these pathways. Although drinking water ingestion is believed to result in the greatest exposure and therefore toxicity, these other pathways may contribute considerably to overall exposure.

\subsection{POTENTIAL CARCINOGENIC HEALTH EFFECTS}

All uranium isotopes are radioactive and, as such, are considered carcinogens. Figure 6.9 shows the exposure distribution for uranium-238 and uranium-234 intake and the associated potential lifetime carcinogenic risk. These estimates are based on the cancer slope factor developed by the EPA; however, natural uranium has not been demonstrated to cause cancer in humans or animals following ingestion.

The average predicted exposure to radioactive uranium is associated with an excess lifetime cancer risk of 1 in 10,000 (0.01 percent), which is the maximum recommended by the EPA in its National Contingency Plan for Superfund sites. The distribution presented here is thought to be conservative because it is based on a cumulative, 30-year exposure duration. As previously discussed, this exposure duration is probably appropriate; however, ground water concentrations may decline over this time.

Uranium and radium-226 are the only radionuclides consistently measured above background levels in the contaminated ground water of the unconfined aquifer. However, because uranium decays to radioactive progeny, the entire longer-lived radioactive progeny of the uranium decay series (radium-226, lead-210, polonium-210, and thorium-230) was evaluated for carcinogenic risk (Table 6.1).

Any excess lifetime cancer risks associated with radionuclides other than uranium are within the NCP-acceptable range of 1 in 10,000 and 1 in $1,000,000$. 


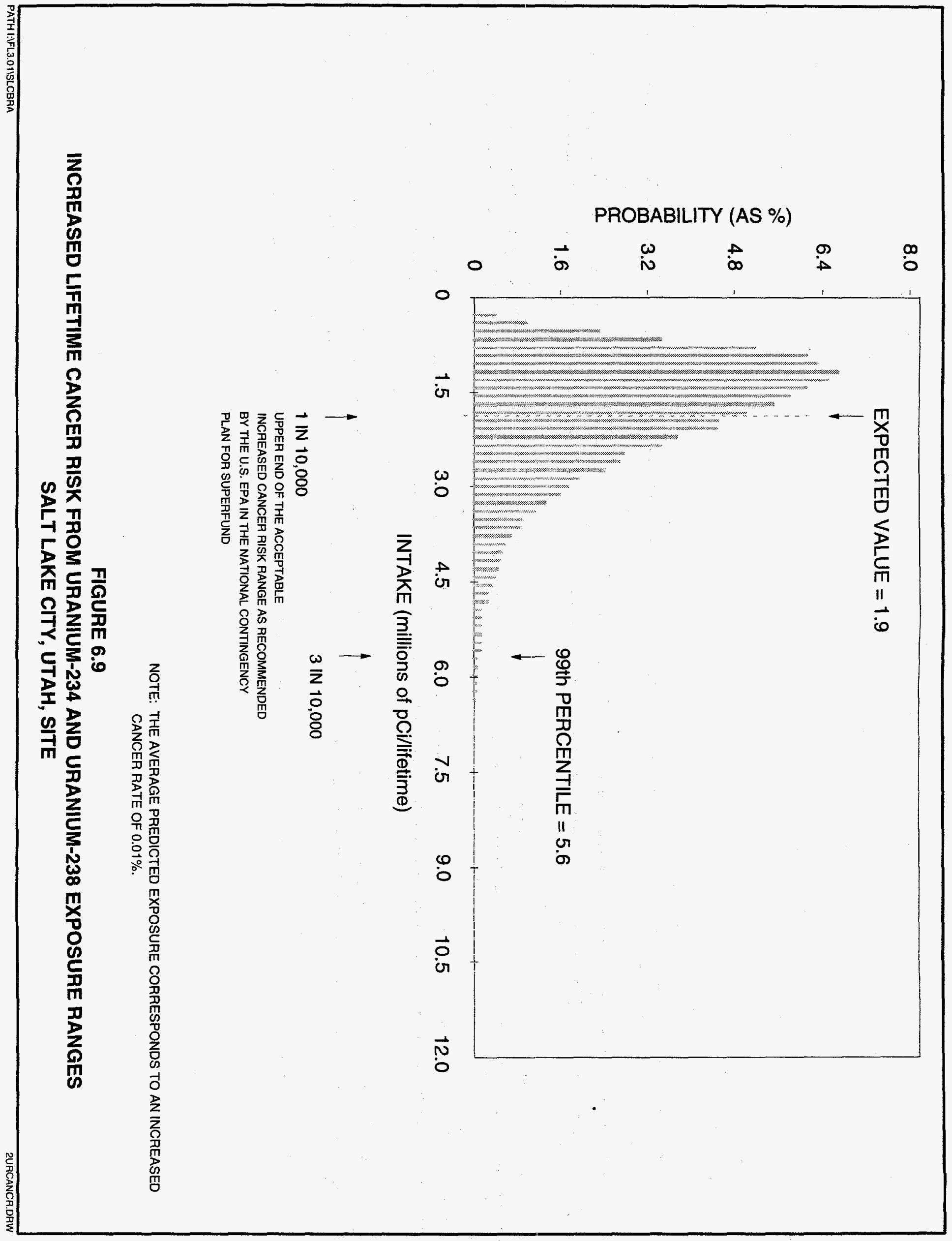


Table 6.1 Carcinogenic risk for ground water consumption pathway, Salt Lake City, Utah, site

\begin{tabular}{lcccc}
\hline \multicolumn{1}{c}{ Radionuclides } & $\begin{array}{c}\text { Exposure point } \\
\text { concentration" } \\
\text { (pCi/L) }\end{array}$ & $\begin{array}{c}\text { Intake" } \\
\text { (pCi/lifetime) }^{*}\end{array}$ & $\begin{array}{c}\text { Ingestion SF } \\
\text { (pCi) }\end{array}$ & Lifetime risk \\
\hline Radium-226 & 1.1 & 23,100 & $2.96 \mathrm{E}-10$ & $7 \mathrm{E}-06$ \\
Lead-210 & 1.4 & 29,400 & $1.01 \mathrm{E}-09$ & $3 \mathrm{E}-05$ \\
Polonium-210 & 0.2 & 4,200 & $3.26 \mathrm{E}-10$ & $1 \mathrm{E}-06$ \\
Thorium-230 & 0.6 & 12,600 & $3.75 \mathrm{E}-11$ & $5 \mathrm{E}-07$ \\
& & & & $4 \mathrm{E}-05$ \\
\hline
\end{tabular}

"Highest observed concentration; unfiltered ground water samples collected in October 1992.

Note: Intake is calculated from equation (2) in Section 4.4.

1. Ingestion rate: 2 liters/day.

2. Exposure frequency: 350 days/year.

3. Exposure duration: 30 years.

\subsection{LIMITS OF THIS RISK EVALUATION}

The following potential limitations should be kept in mind when interpreting this risk evaluation.

- This risk assessment evaluates only risks related to ground water contaminated with inorganics. Potential contamination from organic constituents has not been addressed.

- Populations with potentially increased sensitivity, such as the elderly or individuals with preexisting diseases, were not specifically addressed on the toxicity ranges presented on the graphs. Expected sensitivities in certain groups were discussed in the text to the extent possible.

- Some individuals may be more sensitive to the toxic effects of certain constituents for reasons that have not been determined. Therefore, adverse health effects may occur in sensitive individuals at lower exposure levels.

- Available data on potential adverse health effects may not always be sufficient to accurately determine all health effects because human data are insufficient or exposure ranges differed from exposures expected at this site.

- Although the areal extent of ground water contamination and its movement have been evaluated hydrologically and geochemically, it is possible that the monitoring locations sampled were not in the most contaminated portion of the ground water. Additionally, concentrations may increase or decrease substantially as the contaminated ground water moves. 
- The risk evaluation results presented in this document are based on filtered $(0.45 \mu \mathrm{m})$ ground water samples. Therefore, the potential loss of certain ground water constituents as a consequence of filtration is associated with a source of uncertainties. For example, if concentrations of iron and lead measured in unfiltered ground water samples from monitor well 131 represent true values, ingesting this water could cause toxic effects. Because a high degree of uncertainty is associated with these results, they could not be used in this risk evaluation. Therefore, iron and lead should continue to be monitored in unfiltered ground water samples to verify these data.

- Only the drinking water exposure pathway was considered in depth, although other pathways were screened to determine their contribution. However, the incremental contribution from the ground water-irrigated produce-ingestion pathway could not be estimated here. Therefore, the additivity of exposure from other pathways should be considered.

- Changes in land use at the Vitro site (e.g., pumping from the confined aquifer) may affect current and future ground water conditions.

The evaluation presented here compensated for these limitations wherever possible by presenting toxicity ranges and probabilistic exposure assessments rather than point estimates, incorporating as much variability as could be reasonably defined. The impact of these potential limitations is discussed in Section 8.2. 


\subsection{ECOLOGICAL AND LIVESTOCK RISK EVALUATION}

This section assesses the potential for site-related contaminants to adversely affect the existing biological communities, livestock grazing, and potential agricultural practices in the site area. The EPA currently has no guidance for quantifying potential ecological impacts of hazardous constituents; however, the EPA has developed a qualitative approach for ecological risk evaluations (EPA, 1989b). As part of this qualitative approach, the EPA recommends conducting ecological assessments in a phased approach to ensure the most effective use of resources while all necessary work is conducted (EPA, 1992b).

This approach takes place in four phases: identifying potentially exposed habitats (phase 1), collecting chemistry data (phase 2), collecting biological samples (phase 3), and conducting toxicity testing (phase 4). If the initial inspection of the habitats or the analysis of media samples indicates little or no potential for an ecological risk, the assessment probably will be complete. If early phases of the assessment indicate the contaminants may be adversely affecting ecological receptors, a higher level of analysis may be warranted.

The ecological risk assessment at the Salt Lake City site consists of the first two phases of the EPA's approach. Habitats may have been impacted (phase 11, and water chemistry and sediment data have been collected (phase 2). Data from the first two phases of ecological assessment were used to prepare this baseline risk assessment. Thus, this qualitative approach provides a screening level assessment of the risks associated with potential exposure to contaminated media at the site.

Although determining the effects of a contaminant on the ecosystem may be difficult, sampling environmental media such as surface water can help assess potential ecological risk. The following sections identify areas of contamination and their potential pathways into the aquatic and terrestrial ecosystem at the Salt Lake City site, the potential ecological receptors at the site, the contaminants of potential concern, and how these potential contaminants of concern threaten ecological resources, livestock, and agricultural crops.

\subsection{EXPOSURE PATHWAYS}

The cleanup of surface contamination at the Vitro site included soil excavation from 5 to $35 \mathrm{ft}(2$ to $11 \mathrm{~m})$ depending on the depth of contamination. The average depth of excavation at the site was $13 \mathrm{ft}(4 \mathrm{~m})$. Clean fill was placed in all excavated areas and the ground was recontoured and revegetated (DOE, 1994b).

Surface water bodies at and near the site consist of the South Vitro Ditch, Mill Creek along the northern border, a wetland to the east, and the Jordan River to the west (Figure 2.2). Ground water in the shallow unconfined aquifer beneath the site is contaminated as a result of operations at the former uranium processing site. The ground water table ranges from 5 to $15 \mathrm{ft}(1.5$ to $4.6 \mathrm{~m})$ below the ground surface. The extent of ground water contamination within this aquifer is summarized in Section 3.0. 
The surface water, sediments, and shallow unconfined aquifer represent potential contaminant exposure pathways into the aquatic and terrestrial biological communities at the site. A limited number of surface water and sediment locations were sampled at and near the site to assess these potential pathways.

Contaminated ground water in the unconfined shallow aquifer could enter the ecosystem via plant root uptake or discharge into surface water bodies. There is evidence that the contaminated ground water from the shallow unconfined aquifer is entering the clean fill placed in the excavated area. In 1992, samples were taken from nine boreholes from the native soil material at the interface of the fill material and native soil. These samples were taken from 8.5 to $16 \mathrm{ft} 12.6$ to $4.9 \mathrm{~m}$ ) below land surface and averaged $12 \mathrm{ft}(3.7 \mathrm{~m})$ below land surface. The water depth of wells in the shallow unconfined aquifer ranged from 5 to $13 \mathrm{ft}(1.5$ to $4.0 \mathrm{~m})$ and averaged $7 \mathrm{ft}(2 \mathrm{~m})(\mathrm{DOE}, 1993)$. This indicates that water from the shallow unconfined aquifer has, on the average, moved $4 \mathrm{ft}(1.2 \mathrm{~m})$ into the fill material during the 5-year period since the fill was placed at the site in 1987. Given that both the soil beneath the fill and the shallow aquifer are contaminated, the contaminants could enter the ecosystem from plants extracting contaminants from both these sources. These potential pathways will be assessed in this ecological risk assessment.

The unconfined shallow aquifer discharges into surface water bodies near the site in areas such as Mill Creek and the Jordan River (DOE, 1993). This potential exposure pathway to the aquatic and terrestrial biological communities will also be addressed in this assessment.

A potential exposure pathway that does not now exist at the site but could in the future is the establishment of a well in a contaminated aquifer to create a pond and/or irrigation. Contaminated ground water in a pond could affect wildlife that could drink the water and aquatic organisms (including fish) that could live in the pond. Irrigating with contaminated ground water could lead to the ingestion of contaminants by the human population and wildlife. For this assessment, such a well is assumed to be in the most contaminated portion of the unconfined aquifer.

\subsection{ECOLOGICAL RECEPTORS}

This section describes the terrestrial and aquatic resources present at and near the site, based on information collected during reconnaissance-level surveys conducted at the site and other (published) studies. 


\subsubsection{Terrestrial resources}

The areas that were backfilled after the completion of surface cleanup were revegetated with a mixture of grass and herbaceous species. Most of the site consists of mowed fields; one area is used as a golf driving range.

The South Vitro Ditch traverses the site and consists of a channel about $5 \mathrm{ft}(1.5$ $\mathrm{m}$ ) deep and bordered by a dense growth of woody and herbaceous riparian and wetland plant species. Water flows north on site for about $1500 \mathrm{ft}(460 \mathrm{~m})$ before it goes underground (below the site) and empties into Mill Creek near the northern border of the site. Willow and cottonwood are the common woody species while reed canary grass, goldenrod, and cattail are the common herbaceous species. A submerged aquatic plant of undetermined species is common (TAC, 1993). Wildlife was not observed along this ditch although evidence of muskrat has been observed.

Mill Creek runs north of the site and empties into the Jordan River $0.25 \mathrm{mi}$ $(0.40 \mathrm{~km})$ west of the site. The creek has been channelized and is bordered by industrial facilities in the site area. In some areas, the banks of this creek are covered with woody plant species such as willow, Russian olive, and Chinese elm. In other areas, the vegetation is more open with grass such as reed canary grass being common.

Near the site, the Jordan River is bordered by a thin strip of riparian vegetation that is typically 10 to $50 \mathrm{ft}(3$ to $15 \mathrm{~m})$ wide. Moving away from the river, the riparian zone gives way to buildings, parking lots, lawns, and disturbed ground. The riparian zone is dominated by a dense growth of sapling-size trees, with cottonwood, Russian olive, willows, and salt cedar most common. Reed canary grass is common while the most common herbaceous species observed are goldenrod, thistle, teasel, and burdock. Giant reed and cattail were noted in some areas.

Mallard and domestic geese were observed along both Mill Creek and the Jordan River. Other bird species recorded were the red-winged blackbird, starling, house sparrow, magpie, flicker, and red-tailed hawk. Beaver cuttings were common along the river and one muskrat was observed (TAC, 1993).

Because a marshy area east of the site and near the interstate highway was considered out of the potential zone of influence of the contaminated ground water, this area was not inspected or sampled.

\subsubsection{Aquatic resources}

The results of a fisheries study from 1988 through 1991 along the Jordan River in the Mill Creek area indicate 24 species of fish live in the river; carp, Utah sucker, and fathead minnow are the most abundant. The most abundant game species are walleye, white bass, and green sunfish. The study showed no discernible difference in fish abundance, distribution, or reproductive success at sampling 
stations above and below the confluence of Mill Creek. Reproduction of game fish is low in this section of the Jordan River because spawning habitat is limited. The higher ammonia concentrations in the river below Mill Creek were probably caused by water discharged from the CVWRF sewage disposal facility along Mill Creek. These increased ammonia concentrations do not impact the fish in the Jordan River; the principal factor limiting fish reproduction in the river appears to be the lack of appropriate habitat (Filbert and Holden, 1992).

Chironomidae and Oligochaeta were the dominant benthic taxa collected in the Jordan River both upriver and downriver of Mill Creek. The dominance of these taxa is typical for water bodies such as the Jordan River that have a sandy and silty substrate, relatively warm temperatures, and low water velocities (Filbert and Holden, 1992). During sediment sampling in 1993, the largest number of invertebrates were observed at sample site 185 (Figure 2.2); a few Ephemopteran, Tricopteran larva were noted with a large number of limpets and a few leaches (TAC, 1993).

No fish or invertebrates were observed during surface water and sediment sampling along Mill Creek and the South Vitro Ditch.

\subsection{CONTAMINANTS OF POTENTIAL ECOLOGICAL CONCERN AND ECOLOGICAL} RISK

\subsubsection{Surface water and sediment sampling sites and results}

Surface water and sediment samples were collected in 1993 from four locations along the Jordan River, and three along Mill Creek (Figure 2.2). In addition, sediment samples were collected at locations 186 and 187 along the South Vitro Ditch.

As indicated in Section 3.5, site-related contaminants do not appear to be affecting the Jordan River. Surface water samples from Mill Creek were analyzed for 9 constituents in 1993 (Table 7.1). This screening analysis indicates site-related contaminants in the surface water do not present ecological risk. However this cannot be definitely determined by only one set of samples because seasonal flows and other factors could change water quality significantly.

Sediment samples were collected at all surface water locations in 1993 (Tables 7.2 and 7.3). As with surface water, site-related contaminants do not appear to have affected the Jordan River sediment (Section 3.6). The analysis of sediment samples from Mill Creek in 1993 indicates the constituent concentrations do not increase at the downstream location (sample site 182) and there are no elevated site-related contaminants in the sediment of Mill Creek (Table 7.2). 
Table 7.1 Constituents measured in unfiltered surface water in 1993 in Mill Creek, Salt Lake City, Utah, site

\begin{tabular}{lccccc}
\hline & $\begin{array}{c}\text { Upstream of } \\
\text { site }\end{array}$ & $\begin{array}{c}\text { West of } \\
\text { railroad tracks }\end{array}$ & $\begin{array}{c}\text { Downstream } \\
\text { from sewage } \\
\text { outfall }\end{array}$ & \multicolumn{2}{c}{$\begin{array}{c}\text { Aquatic life water quality } \\
\text { value }\end{array}$} \\
\cline { 2 - 5 } Constituent & 180 & 181 & 182 & $\begin{array}{c}\text { Acute } \\
\text { value }\end{array}$ & $\begin{array}{c}\text { Chronic } \\
\text { value }\end{array}$ \\
\hline Calcium & 104 & 113 & & NA & NA \\
Chloride & 66 & 67 & 85 & $860^{\mathrm{a}}$ & $230^{\mathrm{a}}$ \\
Magnesium & 36 & 39 & 197 & $\mathrm{NA}$ & $\mathrm{NA}$ \\
Molybdenum & $<0.01$ & $<0.01$ & $<5$ & $\mathrm{NA}$ & $50(0.79)^{\mathrm{b}}$ \\
Selenium & $<0.005$ & $<0.005$ & $<0.005$ & $0.02^{\mathrm{c}}$ & $0.005^{\mathrm{c}}$ \\
Silver & $<0.01$ & $<0.01$ & $<0.01$ & $0.01^{\mathrm{a}}$ & $\mathrm{NA}$ \\
Sodium & 35 & 39 & 152 & $\mathrm{NA}$ & $\mathrm{NA}$ \\
Sulfate & 173 & 173 & 141 & $\mathrm{NA}$ & $\mathrm{NA}$ \\
Strontium & 1 & 1 & 0.78 & $\mathrm{NA}$ & $\mathrm{NA}$ \\
Uranium & 0.002 & 0.002 & 0.004 & $11^{\mathrm{c}}$ & $7^{\mathrm{c}}$ \\
\hline
\end{tabular}

a From EPA (1991), chronic Federal Water Quality Criteria for the protection of freshwater aquatic life; based on unfiltered samples.

bo state or federal water quality criteria available. Value presented is the current molybdenum criterion recommended by the U.S. Fish and Wildlife Service for protection of aquatic organisms except for newly fertilized rainbow trout eggs, which are sensitive to molybdenum concentrations above $0.79 \mathrm{mg} / \mathrm{L}$ (Eisler, 1989).

c From water hardness chronic criteria, state of Colorado (CDH, 1991). Criteria calculated using total hardness of $403 \mathrm{mg} / \mathrm{L}$; based on filtered samples.

NA - criteria not available.

ND - not detected.

Note: Concentrations in milligrams per liter. 
Table 7.2 Constituents measured in 1993 in the sediment in Mill Creek, Salt Lake City, Utah, site

\begin{tabular}{|c|c|c|c|c|c|}
\hline \multirow[b]{2}{*}{ Constituent } & \multicolumn{3}{|c|}{ Mill Creek } & \multicolumn{2}{|c|}{ Guidelines for potential effects $^{2}$} \\
\hline & $\begin{array}{c}\text { Upstream of } \\
\text { site }\end{array}$ & $\begin{array}{c}\begin{array}{c}\text { West of } \\
\text { railroad tracks }\end{array} \\
181\end{array}$ & $\begin{array}{c}\begin{array}{c}\text { Downstream } \\
\text { from sewage } \\
\text { outfall }\end{array} \\
182 \\
\end{array}$ & $\begin{array}{c}\text { Lowest effect } \\
\text { level }\end{array}$ & $\begin{array}{c}\text { Medium effect } \\
\text { level }\end{array}$ \\
\hline Calcium & 76100 & 64500 & 8810 & NA & NA \\
\hline Chloride & 110 & 807 & 165 & NA & NA \\
\hline Magnesium & 11000 & 10900 & 13400 & NA & NA \\
\hline Molybdenum & $<4.6$ & $<4.2$ & $<4.1$ & NA & NA \\
\hline Selenium & $<2.3$ & $<2.1$ & $<2.1$ & NA & NA \\
\hline Silver & $<4.6$ & $<4.2$ & $<4.1$ & 1 & 3.7 \\
\hline Sodium & 908 & 857 & 1240 & NA & NA \\
\hline Strontium & 190 & 153 & 83 & NA & NA \\
\hline Sulfate & 60 & 184 & 67 & NA & NA \\
\hline Uranium & 1.3 & 1.4 & 1.2 & NA & NA \\
\hline
\end{tabular}

${ }^{a}$ From Long and Morgan (1990).

NA - guideline not available.

ND - not detected.

Note: All concentrations in milligrams per kilogram. 
Table 7.3 Constituents measured in 1993 in the sediment in South Vitro Ditch, Salt Lake City, Utah, site

\begin{tabular}{|c|c|c|c|c|}
\hline \multirow[b]{2}{*}{ Constituent } & \multicolumn{2}{|c|}{ South Vitro Ditch } & \multicolumn{2}{|c|}{ Guidelines for potential effects ${ }^{a}$} \\
\hline & $\begin{array}{c}\text { South end } \\
186\end{array}$ & $\begin{array}{c}\text { North end } \\
187 \\
\end{array}$ & $\begin{array}{c}\text { Lowest effect } \\
\text { level }\end{array}$ & $\begin{array}{c}\text { Medium effect } \\
\text { level }\end{array}$ \\
\hline Calcium & 69800 & 81700 & NA & NA \\
\hline Chloride & 50 & 130 & NA & NA \\
\hline Magnesium & 3710 & 16500 & NA & NA \\
\hline Molybdenum ${ }^{b}$ & 6.6 & 236 & NA & NA \\
\hline Silver & $<2.7$ & $<6.4$ & 1 & 3.7 \\
\hline Selenium & $<1.4$ & $<3.2$ & NA & NA \\
\hline Sodium & 718 & 1600 & NA & NA \\
\hline Strontium & 79 & 227 & NA & NA \\
\hline Sulfate & 99 & 247 & NA & NA \\
\hline Uranium & 3.9 & 4.8 & NA & NA \\
\hline
\end{tabular}

a From Long and Morgan (1990).

b Observed range of molybdenum concentrations in samples of soil from the western United States is less than 3 to $7 \mathrm{mg} / \mathrm{kg}$ (USGS, 1984).

NA - guideline not available.

Note: All concentrations in milligrams per kilogram. 
Sediment samples from the South Vitro Ditch had a high concentration of molybdenum (236 mg/kg) at the north end (sample site 187) and a lower concentration at the south end $(6.6 \mathrm{mg} / \mathrm{kg}$ ) (sample site 186) relative to levels in Mill Creek and the Jordan River (Table 7.3). The molybdenum level at location 187 was higher than the range of molybdenum concentrations found in soils in the western United States (less than 3 to a maximum of $7 \mathrm{mg} / \mathrm{kg}$ ) (USGS, 1984 and the suggested maximum acceptable concentrations of $37 \mathrm{mg} / \mathrm{kg}$ for soils at UMTRA Project sites (JEG, 1986).

Molybdenum in the South Vitro Ditch sediment could enter the biological communities via uptake by aquatic benthic invertebrates and/or plants growing in and near the zone of molybdenum contamination. Molybdenum is absorbed by plants primarily in the water soluble form (Kubota et al., 1961). The amount of molybdenum in soils or sediments that is available to plants varies widely among plant species and soil chemistry. The $\mathrm{pH}$, percent organic matter, water content, and concentrations of elements such as iron, phosphate, and sulfate can affect the availability of molybdenum to plants (Davies, 1956; Kubota et al., 1961). For the South Vitro Ditch, a relatively high concentration of molybdenum is assumed to be available to plants because higher availability of this element has been documented for waterlogged soils. This availability occurs as inundation produces reducing conditions that release molybdenum from iron molybdate (Jarrell et al., 1980). The concentrations of molybdenum in plants growing in and along the South Vitro Ditch were not measured. The amount of molybdenum in the plants at the north end of this ditch was estimated by assuming a transfer coefficient from dry soil to plants of 0.12 (NRC, 1977). This coefficient may underestimate the transfer of molybdenum to plants because, as stated above, more molybdenum may be transferred to plants from waterlogged soil than dry soil. The estimated concentration of molybdenum in plants along the ditch is $28 \mathrm{mg} / \mathrm{kg}$, using the transfer coefficient of 0.12 (DOE, 1995a).

According to Jarrell et al. (1980), molybdenum has never been shown to reach toxic concentrations for field-grown crops. However, it is known to be phytotoxic to some agricultural plants at concentrations of 2 to $10 \mathrm{mg} / \mathrm{kg}$ (Kabata-Pendias and Pendias, 1992). If the molybdenum concentration in the plants along the South Vitro Ditch is $28 \mathrm{mg} / \mathrm{kg}$, plant species that are sensitive to molybdenum toxicity may have been negatively impacted. However, it could not be determined with existing data whether plant species growing at the Vitro site could be harmed by this level of molybdenum.

Molybdenum has been shown to be toxic to certain animal species; ruminants such as cattle and sheep are the most sensitive. Generally, 2 to $5 \mathrm{mg} / \mathrm{kg}$ of molybdenum in vegetation represents the upper level of tolerance for these animals (Erdman et al., 1978). The potential impact of molybdenum on cattle and sheep is discussed in more detail in Section 7.4. Birds and mammals are comparatively tolerant to a high dietary intake of molybdenum (Eisler, 1989). For example, mule deer tolerate 10 times more molybdenum in their diet than cattle (Jarrell et al., 1980). The molybdenum concentrations in the sediments at the north end of the South Vitro Ditch could pose a potential ecological risk to terrestrial plant and animal communities in the area directly adjacent to the 
contaminated sediments; however, the extent of the elevated molybdenum contamination along the South Vitro Ditch is not known.

\subsubsection{Ecological risk associated with plant root transport of contaminants}

Plant root transport of contaminants to the surface could occur if roots grew into the contaminated unconfined aquifer. Samples of the native material just below the clean fill were collected from nine locations at the site (Figure 2.2). Twentyfour constituents were measured in this material; the high concentrations tended to be in the north, east, and south ends of the site; the lowest concentrations were along the western boundary (sample locations 573, 577, and 578) (Table 7.4). Data regarding soil concentrations that may be phytotoxic are not available for 9 of these constituents. The remaining 15 constituents were compared to soil concentrations screening benchmarks; arsenic, chromium, cobalt, manganese, molybdenum, vanadium, and zinc levels exceeded the benchmarks (Table 7.5). These concentrations were generally found at the center (location 575) and south end (location 572) of the site. The minimum depth of this contaminated material at the 9 boreholes is $8.5 \mathrm{ft}(2.6 \mathrm{~m})$ and the average depth is $12 \mathrm{ft}(3.7 \mathrm{~m})$.

The species composition of the grass/herb-dominated plant community in the site area is not known but these plants probably have not grown through the fill material into the underlying material for the following reasons:

- Although some grass and herbaceous plant species can send roots down 4 to $6 \mathrm{ft}(1$ to $2 \mathrm{~m})$ (such as crested wheatgrass and Russian thistle) (Anderson, et al., 1987; Reynolds, 1990), the contaminated material under the fill material is believed to be beyond the reach of most grass and herbaceous plant species.

- Plants growing in the site area can reach water at shallower depths, both from the unconfined aquifer (no deeper than $5 \mathrm{ft}[2 \mathrm{~m}]$ from the surface) and from irrigation water for the golf driving range.

Because the woody plants and other species growing along the South Vitro Ditch probably obtain water from the ditch, they do not need very deep roots.

Therefore, the contamination in the material below the clean fill at the site will not affect the ecosystem.

The unconfined aquifer occurs within $5 \mathrm{ft}(2 \mathrm{~m})$ or less of the surface in some areas of the site. This water may be utilized by some plants growing in the grass/herb plant community. The contaminants in this aquifer are potentially toxic to the plants themselves (phytotoxicity) and may move up the food chain via herbivores feeding on the plants. The concentrations of contaminants of potential concern were not measured in plants growing on the site. To determine if the contaminants of potential concern could be phytotoxic, the concentrations of these constituents in the unconfined aquifer were compared to screening 


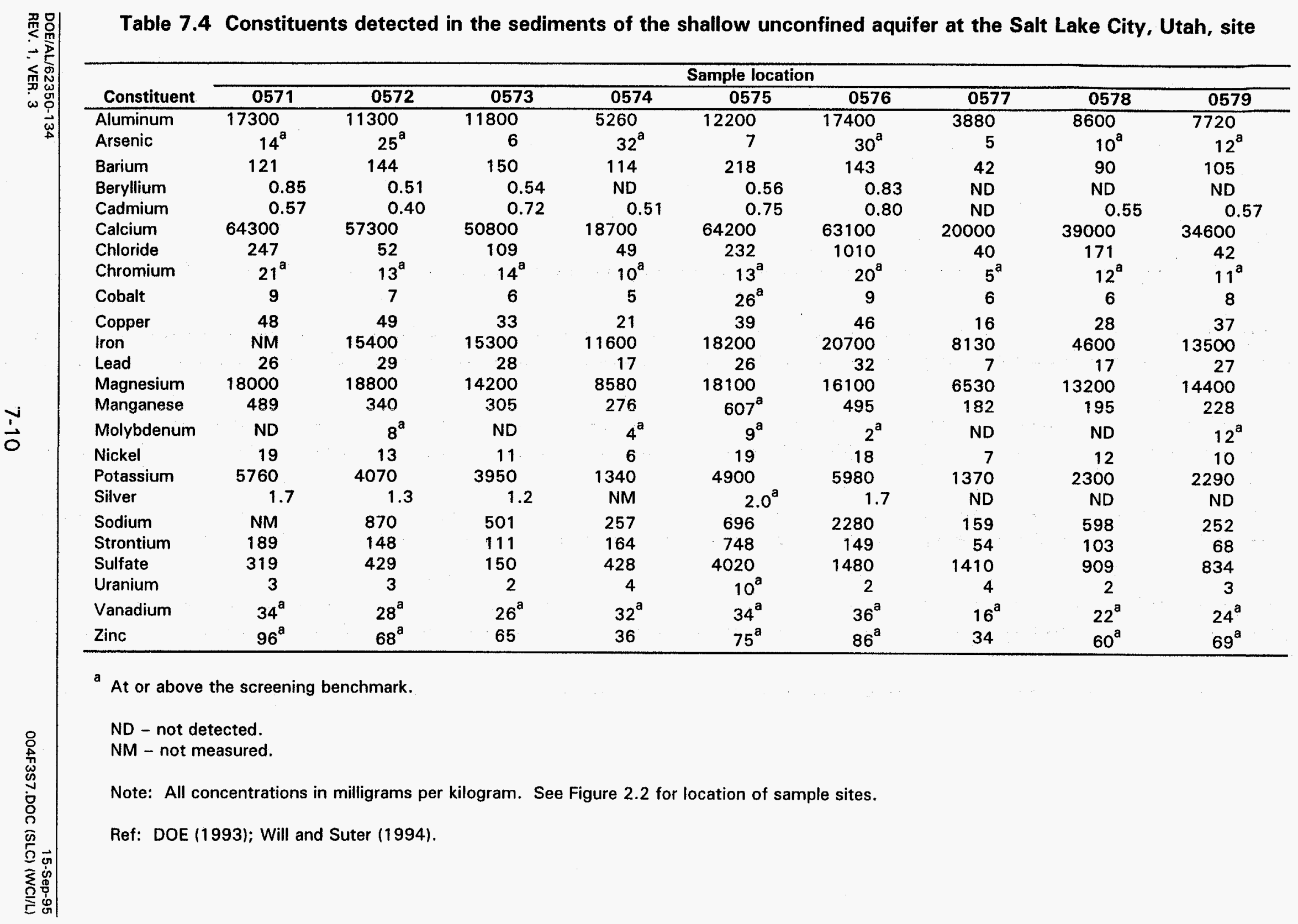


Table 7.5 Comparison of deep soil concentration of contaminants of potential concern to screening benchmarks for terrestrial plants

\begin{tabular}{lccc}
\hline \multicolumn{1}{c}{$\begin{array}{c}\text { Contaminants of } \\
\text { potential concern }\end{array}$} & \multicolumn{2}{c}{$\begin{array}{c}\text { Deep soil concentrations } \\
\text { (mg/kg) }\end{array}$} & $\begin{array}{c}\text { Screening benchmarks } \\
\text { for terrestrial plants } \\
\text { b }\end{array}$ \\
\cline { 2 - 4 } (mg/kg)
\end{tabular}

a Samples collected from nine locations 8 to $16 \mathrm{ft}(2$ to $5 \mathrm{~m})$ below land surface.

brom Will and Suter (1994).

ND - not detected.

Ref.: DOE (1993). 
benchmarks for terrestrial plants (Table 7.6). These benchmarks represent concentrations where potential negative effects to some plant species may first become evident. Plant uptake and response to the contaminants varies widely among plant species. Other factors, such as soil characteristics and water chemistry, also can cause wide variations in plant uptake of specific constituents. This analysis was performed to provide an order-of-magnitude estimate of the potential phytotoxicity of these contaminants.

The results of this analysis indicate estimated concentrations of molybdenum slightly exceed the plant screening benchmarks (Table 7.6). Although molybdenum concentrations were not measured in the vegetation at the site, this analysis indicates that molybdenum concentrations in the shallow unconfined aquifer beneath the site may have a slight negative effect on molybdenumsensitive plants.

As indicated in Section 7.3.1, terrestrial wildlife species are resistant to molybdenum's toxic effects. Any slight impact of molybdenum to terrestrial plants would likely have no impact on wildlife that feed on these plants.

\subsubsection{Ecological risk associated with stock ponds and irrigation water}

A pond filled with contaminated ground water from the unconfined aquifer may create another hypothetical pathway into the aquatic and terrestrial ecosystem. Fourteen constituents exceed background concentrations in the shallow unconfined aquifer beneath the site (Table 7.7). These concentrations were compared to aquatic life water quality criteria; chloride, iron, and silver levels exceeded these values.

Chloride. The maximum concentration of chloride is $2830 \mathrm{mg} / \mathrm{L}$, much higher than the maximum background level $(74 \mathrm{mg} / \mathrm{L})$ as well as the chronic $(230 \mathrm{mg} / \mathrm{L})$ and acute criteria $(860 \mathrm{mg} / \mathrm{L}$ ) considered protective of aquatic life (EPA, 1991). Data are not available on the nature and severity of the effects of elevated chloride on aquatic and terrestrial ecological systems.

Iron. The maximum concentration of iron is $6.5 \mathrm{mg} / \mathrm{L}$, which is elevated above the maximum background level of $0.25 \mathrm{mg} / \mathrm{L}$ and the chronic Federal Water Quality Criteria of $1.0 \mathrm{mg} / \mathrm{L}$. Data are not available on the severity of the effects of elevated iron on the terrestrial and aquatic ecosystems.

Silver. Other than a concentration of $0.019 \mathrm{mg} / \mathrm{L}$ of silver in well 008 in 1991 , silver was not detected in monitor wells at the site until October 1992, when it was detected in seven of 10 wells sampled. Concentrations in the seven wells were 1 order of magnitude above the acute toxicity criterion for freshwater $(0.0018 \mathrm{mg} / \mathrm{L})$ and 2 orders of magnitude greater than the chronic aquatic life criterion of $0.00012 \mathrm{mg} / \mathrm{L}$. Because the detection limit for silver was $0.01 \mathrm{mg} / \mathrm{L}$, silver levels may have exceeded the aquatic life value at wells where silver was reported as undetected. Therefore, using ground water from the unconfined aquifer as a source for a pond could cause acute and chronic effects 
Table 7.6 Comparison of contaminant levels in the unconfined shallow aquifer to screening benchmarks for terrestrial plants

\begin{tabular}{lcc}
\hline \multicolumn{1}{c}{$\begin{array}{c}\text { Contaminants of potential } \\
\text { concern }\end{array}$} & $\begin{array}{c}\text { Maximum concentration in } \\
\text { unconfined shallow aquifer }\end{array}$ & $\begin{array}{c}\text { Screening benchmarks for } \\
\text { terrestrial plants }\end{array}$ \\
\hline Barium & 0.61 & $\mathrm{NA}$ \\
Calcium & 426 & $\mathrm{NA}$ \\
Chloride & 2830 & $\mathrm{NA}$ \\
Copper & 0.01 & 0.03 \\
Fluoride & 2.7 & 5 \\
Iron & 6.5 & 10 \\
Magnesium & 900 & $\mathrm{NA}$ \\
Manganese & 0.63 & 4 \\
Molybdenum & 0.94 & 0.5 \\
Potassium & 228 & $\mathrm{NA}$ \\
Silver & 0.041 & 0.1 \\
Sodium & 3160 & $\mathrm{NA}$ \\
Strontium & 4.4 & $\mathrm{NA}$ \\
Sulfate & 5560 & $\mathrm{NA}$ \\
Uranium & 0.27 & 40 \\
\hline
\end{tabular}

${ }^{a}$ From Will and Suter, 1994.

NA - not available.

Note: Concentrations in milligrams per liter. 
Table 7.7 Comparison of contaminant concentrations in the shallow unconfined aquifer to water quality criteria, Salt Lake City, Utah, site

\begin{tabular}{|c|c|c|c|c|}
\hline Constituent & $\begin{array}{c}\text { Maximum } \\
\text { observed } \\
\text { concentration }\end{array}$ & $\begin{array}{l}\text { Aquatic life water } \\
\text { quality value }\end{array}$ & $\begin{array}{c}\text { Water } \\
\text { concentrations } \\
\text { protective of } \\
\text { livestock }^{\mathrm{a}}\end{array}$ & $\begin{array}{c}\text { Concentration in } \\
\text { irrigation water } \\
\text { protective of } \\
\text { plants }\end{array}$ \\
\hline Barium & 0.61 & NA & NA & NA \\
\hline Calcium & 4.26 & NA & NA & NA \\
\hline Chloride & 2830 & $230^{b}$ & c & NA \\
\hline Fluoride & 2.7 & NA & 2.0 & 1.0 \\
\hline Iron & 6.5 & $1.0^{\mathrm{d}}$ & c & 5.0 \\
\hline Magnesium & 900 & NA & c & NA \\
\hline Manganese & 0.63 & $1.5^{\mathrm{e}}$ & NA & 0.2 \\
\hline Molybdenum & 0.94 & $50(0.79)^{f}$ & NA & 0.01 \\
\hline Potassium & 228 & NA & NA & NA \\
\hline Silver & 0.041 & $0.00012^{a}$ & NA & NA \\
\hline Sodium & 3160 & NA & NA & NA \\
\hline Strontium & 44 & NA & NA & NA \\
\hline Sulfate & 5560 & NA & $1000^{9}$ & NA \\
\hline Uranium & 0.27 & $8.43^{h}$ & NA & NA \\
\hline Vanadium & 0.071 & NA & 0.1 & 0.1 \\
\hline
\end{tabular}

a From EPA (1973) unless specified otherwise. Irrigation water values shown are for water used continuously on all soils.

b From EPA (1991), chronic Federal Water Quality Criteria for the protection of freshwater aquatic life.

c Determination of concentration protective of livestock not deemed necessary (EPA, 1973).

d From UDEO (1992); numeric chronic criteria for aquatic life based on a 4-day average concentration. Criteria should not be exceeded more than once every 3 years on the average.

e From EPA (1986). Value presented is the lower end of the tolerance range for aquatic life.

f Value from Eisler (1989).

${ }^{9}$ From Church (1984).

${ }^{\mathrm{h}}$ From water hardness chronic criteria (CDH, 1991).

NA - not available. 
on aquatic invertebrates and fish. Negative effects could also be expected for some aquatic plants. For example, some algae had a 96-hour effective concentration (EC) EC-50 of $0.0026 \mathrm{mg} / \mathrm{L}$; effects to vascular plants are unlikely because they had EC-50s ranging from 0.27 to $7.5 \mathrm{mg} / \mathrm{L}$ of silver (EPA, 1987).

Bioconcentration factors (BCF) for silver in freshwater fish ranged from 11 to 150 while mean BCFs for freshwater invertebrates were 37 to 84 (EPA, 1987). This indicates that silver could be transported up the food chain and enter the terrestrial environment in a pond using water from the unconfined aquifer.

Another hypothetical pathway is irrigation with contaminated ground water from the unconfined aquifer. The criteria protective of plants (EPA, 1973) were compared to the maximum concentrations for the contaminants of potential concern (Table 7.7). Such criteria exist for 5 of the 15 contaminants of potential concern listed in Table 7.7; fluoride, iron, manganese, and molybdenum exceed these criteria. Excessive fluoride levels in irrigation water can reduce plant yield and the germination. It has also been found that cattle can accumulate relatively high levels of fluoride in their bones (over $2000 \mathrm{mg} / \mathrm{kg}$ of bone) if they graze on forage high in fluoride. Iron in irrigation water is not likely to result in plant toxicity. However, iron can decrease the availability of essential elements such as phosphorous and molybdenum. Manganese levels of a few tenths to a few milligrams per liter can be toxic to some crops although this toxicity can be reduced by increasing the $\mathrm{pH}$. Molybdenum concentrations in the unconfined aquifer (maximum concentration of $0.94 \mathrm{mg} / \mathrm{L}$ ) would not be toxic to irrigated plants. The potential negative effect could be on livestock that fed on the forage irrigated with water from this aquifer.

\section{$7.4 \quad$ POTENTIAL IMPACTS TO LIVESTOCK}

Livestock do not graze within the site boundary. However, cattle graze just south of the site and horses are kept west of the site. There are no plans to allow grazing at the site but livestock could be kept within the site boundary in the future.

The constituent concentrations in the surface water do not threaten livestock. However, molybdenum concentrations may be elevated in plants along part of South Vitro Ditch as a result of contaminated sediments and elsewhere at the site as a result of contaminated ground water in the shallow unconfined aquifer. Molybdenum concentration in plants were not measured at the site. However, the estimated molybdenum concentration in plants growing at the north end of the South Vitro Ditch is $28 \mathrm{mg} / \mathrm{kg}$, based on literature values (DOE, 1995a). The concentration of molybdenum in plants that may be rooted in the shallow unconfined aquifer was not estimated. The estimated concentration in the ditch exceeds the limits $(2$ to $5 \mathrm{mg} / \mathrm{kg}$ ) of molybdenum in forage that can be tolerated by cattle (Erdman et al., 1978). The negative effects of molybdenum can be offset if the ratio of copper to molybdenum is at least 2 to 1 (Erdman et al., 1978). However, the copper-to-molybdenum ratio at the site is unknown at present. Therefore, it cannot be determined with existing data whether molybdenum levels could affect cattle or sheep if they were grazing in the site area in the future. 
A hypothetical pathway for contaminants from the unconfined aquifer to enter the environment would be the construction of a pond which uses this water. Values that are considered protective of livestock water supplies are available for 3 of the 15 constituents that exceed background concentrations in the unconfined aquifer (Table 7.7). Fluoride and sulfate exceed these values. Cattle drinking water with as little as $2 \mathrm{mg} / \mathrm{L}$ fluoride suffer from tooth mottling, but a much larger increase in fluoride concentrations is required before other harmful effects are observed (EPA, 1973). Sulfate concentrations are highly elevated in the unconfined aquifer and consuming this water could result in diarrhea (Church, 1984).

\subsection{UNCERTAINTIES OF THE ECOLOGICAL RISK ASSESSMENT}

The qualitative evaluation of potential ecological risks presented here is a screening-level assessment of the risks associated with potential exposure of plants and animals to contaminated ground water, surface water, and sediment at the Salt Lake City site. Sources of uncertainty in any ecological assessment arise from the monitoring data, exposure assessments, toxicological information, and inherent complexity of the ecosystem. In addition, methods of predicting nonchemical stresses (e.g., drought), biotic interactions, behavior patterns, biological variability (i.e., differences in physical conditions, nutrient availability), and resiliency and recovery capacities often are unavailable. The Salt Lake City ecological risk assessment includes the following general limitations:

- Only a small amount of ecological data were collected during this screening.

- General literature values were used in many cases because little is known about site-specific intake rates for wildlife and the amounts of contaminants taken up by plants.

- Ecotoxicological reference data are limited.

- Considerable uncertainty is associated with the toxicity of multiple contaminants.

\subsection{SUMMARY}

Surface water sampling from the Jordan River indicates that these waters are not contaminated as a result of uranium processing at the Salt Lake City site. As discussed in Section 3.6, Mill Creek may be receiving a small amount of uranium from the site. However, this conclusion is based on limited sampling.

Site-related contaminants were identified in sediment samples from these water bodies only in the South Vitro Ditch, where a high molybdenum concentration was encountered at one location. The molybdenum contamination in these sediments has a potential to affect the aquatic organisms in the ditch and the wetland plants adjacent to the ditch. However, it cannot be determined with existing data whether these levels of molybdenum could harm plant species growing on the site. 
After tailings cleanup, an average of $12 \mathrm{ft}(4 \mathrm{~m})$ of clean fill was deposited on the site. Concentrations of arsenic, chromium, cobalt, manganese, molybdenum, and zinc in the native material below this clean fill are at levels above screening benchmarks for terrestrial plants. However, it is believed that few if any plants are sending roots into this material because of its depth and the availability of water at shallower depths.

Plants may be sending roots into the shallow unconfined aquifer because this water is available at a depth of $5 \mathrm{ft}(2 \mathrm{~m})$ or less in some locations. The concentrations of constituents in the contaminated alluvial aquifer were compared with screening benchmarks for terrestrial plants, and molybdenum was the only constituent to exceed these benchmarks. This constituent was just above the benchmark, indicating only slight effects, if any, would be seen in the vegetation.

A hypothetical pathway to ecological receptors considered was a pond filled with contaminated water from the unconfined aquifer. It was determined that concentrations of chloride, iron, and silver would exceed the chronic federal water quality criteria for protection of aquatic life, while chloride and silver would also exceed the acute federal water quality criteria.

Water from the unconfined aquifer has concentrations of fluoride, iron, manganese, and molybdenum that are not suitable for livestock. Livestock do not graze on the site and there are no future plans for irrigation. Using water from the unconfined aquifer in a pond would likely result in water high in fluoride and sulfate which could have deleterious effects on livestock. 


\subsection{INTERPRETATION AND RECOMMENDATIONS}

\subsection{RISK SUMMARY}

The UMTRCA requires the UMTRA Project to protect public health and the environment from radiological and nonradiological hazards associated with the uranium mill sites. This baseline risk assessment was conducted for the contaminated ground water at the former Salt Lake City uranium processing site to evaluate the presence of these hazards. This risk assessment is conservative in the sense that it evaluates the residential exposure scenario associated with the highest exposure level from drinking the water from the most contaminated wells on the site. Because contaminated ground water is not currently used by area residents, human health is not at risk. This situation will continue if land and water use at the site remain the same. Changes of land use may or may not create future risks. When specific land uses are determined for the site, these uses should be evaluated to identify potential health and environmental risks from the contaminated ground water.

Health risks could be associated with potential future use of contaminated ground water from the unconfined (shallow) aquifer. However, the likelihood of such use is considered low because the natural quality of the water from this aquifer is considered poor in the site area (Minor, 1995; USGS, 1984; DNR, 1971) due to naturally high levels of total dissolved solids. If background ground water in the shallow aquifer near the site were used as drinking water, ambient levels of arsenic could result in an increased skin cancer risk of about 1 in 1000 (DOE, 1995a). This risk level would exceed the EPA's Superfund National Contingency Plan (NCP) guidance by a factor of 10 . Note, however, that in the future residential scenario, only the people who drilled a well in the most contaminated portion of the aquifer (a fraction of the site) could experience the health problems discussed below. Drinking the water from a future well drilled further off the site could be associated with risks lower than estimated here. Furthermore, the ground water contaminant concentrations will decline over time.

The risks associated with future ground water use of the unconfined aquifer for drinking purposes are unacceptable for sulfate, magnesium, fluoride, manganese, molybdenum, sodium, and chloride. The sulfate in this water is potentially in the severe toxicity range, particularly for infants following short-term exposure. Sulfate levels are associated with severe diarrhea, which could lead to dehydration. The effect is reversible and diarrhea would terminate after the substitution of water low in sulfate for contaminated water.

Although the sulfate toxicity could preclude chronic exposures, the effects from long-term exposures to contaminants other than sulfate are also discussed. The magnesium concentration in the contaminated ground water could enhance the severity of sulfate-induced diarrhea, and could depress the central nervous system, especially if the kidney function was impaired for other reasons. The fluoride levels could result in dental fluorosis in children. The manganese and molybdenum concentrations could be associated with the development of mild neurological 
symptoms and copper deficiency, respectively. Finally, the sodium chloride level could result in hypertension in sensitive people. Diarrhea-induced dehydration may enhance the toxicity of other contaminants, especially magnesium, manganese, and molybdenum.

In addition to human health risks, the concentrations of molybdenum, fluoride, manganese, and iron may limit the potential use of ground water for irrigating crops and pasture. Sulfate, fluoride, and molybdenum concentrations preclude watering livestock with contaminated ground water. Concentrations of chloride and iron in the contaminated ground water are toxic to many aquatic organisms, precluding its use in a stock pond.

Moreover, high molybdenum concentrations in the South Vitro Ditch sediments may have toxic effects on the aquatic organisms within the ditch and the wetland plants adjacent to the ditch.

\subsection{LIMITATIONS OF THIS RISK ASSESSMENT}

The following limitations to this evaluation of health and environmental risks should be noted:

- Uncertainties regarding potential future contamination of the confined aquifer.

- Uncertainties from ongoing site development.

- Uncertainties arising from the use of filtered versus unfiltered water samples. In general, the results presented in this document are based on filtered $(0.45 \mu \mathrm{m})$ water samples. The effect of filtration differs for different elements. Constituents in suspension may be lost with filtration, but can still produce toxic effects if ingested and broken down in the acidic environment of the stomach. If concentrations of iron and lead measured in the unfiltered ground water sample from monitor well 131 represent true values, ingesting this water would be associated with toxic effects from the levels of these elements. Because a high degree of uncertainty (see Section 3.0 ) is associated with these results, they could not be used in this risk evaluation.

- Contaminant toxicities vary from person to person. Presenting probability distributions (for potential exposure) and exposure ranges that can produce toxic effects emphasizes these variabilities. However, it is not possible to account for all sources of variability and still present useful and meaningful analyses.

- Specific subpopulations known to be more sensitive to toxicity of given constituents are noted. Exposure ranges and distributions for expected toxic effects enhance understanding of the potential for toxicity occurrence. 
- Standardized reference values from regulatory agencies and literature values are used to determine toxic effects in humans. However, some data obtained from laboratory animal testing at exposure doses different from those expected at the site were used to determine toxicity. The relationship between dose and response is not always linear, and humans do not always exhibit the same responses as animals. Additionally, data used to determine toxicity generally are based on exposure to only the constituent of concern. In reality, exposures generally occur simultaneously to multiple constituents. The interactive effects of multiple constituents and the impact of these interactions on expected toxicity generally cannot be accurately assessed from existing data.

- Considerable effort went into determining the areal extent of contaminated ground water and its movement, and placing monitor wells in locations that capture maximal contamination. Variability in physical systems and models used to determine contaminant plume migration could still result in well placements that do not measure the highest contaminant concentrations or determine the fullest extent of plume impact. On the other hand, because the major source of contamination (the tailings and contaminated soils) at the Vitro site has been removed, the assumption of a constant source used in this risk assessment may lead to an overestimation of risks. Because the contaminant concentrations could be higher or lower than those used in the analysis, the net effect of these uncertainties on future risk estimates cannot be predicted at this time.

- Variability can be introduced through sampling and analytical processes. However, the data at UMTRA Project sites have been collected over many years and subjected to rigorous quality assurance procedures to minimize this source of variability. Testing multiple samples introduces high confidence in the reliability and validity of the collected data.

- Due to insufficient data, the incremental contribution from the ground waterirrigated produce ingestion pathway could not be estimated in this risk assessment. Therefore, the possibility of exposure from this pathway may need to be evaluated.

- The limitations for the Salt Lake City ecological risk assessment include limited amounts of ecological data collected during this screening, little knowledge about site-specific intake rates for wildlife or amounts of contaminants taken up by plants, limited ecotoxicological reference data, and considerable uncertainty associated with the toxicity of mixed contaminants.

Presenting ranges of toxic effects, probable exposure distributions, summaries of available data on health effects and interactions, and outlines of potential limitations ensures a reasonable interpretation of potential health risks associated with ground water contamination at this site. This assessment describes 
contamination and risk as accurately as possible, based on available data, and conveys areas of uncertainties.

\subsection{GROUND WATER CRITERIA}

In 1983, the EPA established health and environmental protection standards for the UMTRA Project (40 CFR Part 192). The standards were revised and the final rule was published on 11 January 1995 (60 FR 2854 (1995)). The ground water standards consist of ground water protection standards to evaluate disposal cell performance and ground water cleanup standards for existing contamination at processing sites. Concentration limits for constituents at the site are summarized in Table 8.1. Maximum concentration limits (MCL) are not established for every contaminant; for contaminants without MCLs, background levels must be met. The standards also allow for supplemental standards or alternate concentration limits, where appropriate.

In general, EPA ground water standards are sufficient to protect human health and the environment. However, some risk assessments may identify sitespecific factors that suggest these standards are not appropriate. When standards are too restrictive as, for example, when there may be no potential for exposure, a less restrictive alternate concentrate limit may be sought.

While these ground water protection and cleanup standards apply specifically to the UMTRA Project, the EPA has also published drinking water health advisory (EPA, 1993) levels for long- and short-term exposures to contaminants in ground water (Table 8.1).

The following contaminant concentrations in contaminated wells in the unconfined aquifer have consistently exceeded the EPA ground water standards and/or the EPA health advisory levels: antimony, arsenic, molybdenum, selenium, and uranium. Arsenic exceeded its $\mathrm{MCL}$, and antimony exceeded its health advisory level in background well 007.

\subsection{RISK MITIGATION MEASURES}

Use of the contaminated ground water from the shallow, unconfined aquifer below the Salt Lake City former uranium processing site could cause health problems. Although the former processing site is in an urban area, adjacent to local residences, water from the unconfined aquifer is not known to be used for any purpose. Although drilling a shallow well does not require a permit, the county may withhold a water supply approval if samples from the well do not meet the quality requirements of the State of Utah Public Drinking Water Regulations (SLCC, 1981; Minor 1995). However, the standards and regulations applicable to uses other than domestic purposes are not clear. Note, however, that contaminated ground water expresses itself in the South Vitro Ditch, creating possible exposure pathways to environmental receptors. 
Table 8.1 Concentration limits of constituents

\begin{tabular}{|c|c|c|c|}
\hline Constituent & $\begin{array}{l}\text { EPA MCL } \\
\text { for UMTRA } \\
\text { (mg/L) }\end{array}$ & $\begin{array}{c}\text { Health advisories } \\
\text { 10-kg child, 10-day } \\
\text { (mg/L) }\end{array}$ & $\begin{array}{c}\text { Health advisories } \\
\text { 70-kg adult, lifetime } \\
\text { (mg/L) }\end{array}$ \\
\hline \multicolumn{4}{|c|}{ Chemical (inorganic) } \\
\hline Antimony & NA & $0.01^{b, c}$ & $0.003^{b, c}$ \\
\hline Arsenic & $0.05^{B, C}$ & NA & NA \\
\hline Barium & 1.0 & NA & 2 \\
\hline Boron $^{d}$ & NA & 0.9 & 0.6 \\
\hline Cadmium & 0.01 & 0.04 & 0.005 \\
\hline Chromium & 0.05 & 1.0 & 0.1 \\
\hline Lead & 0.05 & NA & $0.015^{e}$ \\
\hline Mercury & 0.002 & NA & 0.002 \\
\hline Molybdenum & $0.1^{c}$ & $0.04^{c}$ & $0.04^{c}$ \\
\hline Nickel & NA & 1.0 & 0.1 \\
\hline Nitrate (as $\mathrm{NO}_{3}{ }^{-}$) & $44^{\mathrm{F}}$ & $44^{9}$ & NA \\
\hline Selenium & $0.01^{c}$ & NA & NA \\
\hline Silver & 0.05 & 0.2 & 0.1 \\
\hline Strontium & NA & 25.0 & 17 \\
\hline Thallium & NA & 0.007 & 0.0004 \\
\hline Zinc & NA & 6.0 & 2 \\
\hline \multicolumn{4}{|l|}{ Radionuclide } \\
\hline Radium-226/-228 & $5 \mathrm{pCi} / \mathrm{L}$ & NA & NA \\
\hline $\begin{array}{l}\text { Uranium } \\
\text { (U-234/-238) }\end{array}$ & $\begin{array}{c}30 \mathrm{pCi} / \mathrm{L}^{\mathrm{c}} \\
(0.044 \mathrm{mg} / \mathrm{L})\end{array}$ & $0.03 \mathrm{mg} / \mathrm{L}^{\mathrm{chh}, \mathrm{i}}$ & $0.1 \mathrm{mg} / \mathrm{L}^{\mathrm{c}, \mathrm{h}}$ \\
\hline
\end{tabular}

${ }^{a}$ Drinking Water Regulations and Health Advisories (1995). Office of Water, U.S. Environmental Protection Agency, Washington, D.C.

${ }^{b}$ Exceeded in background well samples.

${ }^{\mathrm{c}}$ Exceeded in contaminated well samples.

${ }^{d}$ Not monitored from 1990 to 1994.

eAction level.

Equals $10 \mathrm{mg} / \mathrm{L}$ nitrate as nitrogen.

Gunder review.

h Proposed value under review; revision expected in 1995.

iLonger-term health advisory.

NA - not available. 


\section{State of Utah}

The state of Utah requires that permits for new ground water wells must be obtained from the state engineer's office. The Salt Lake City/County Health Department regulation \#11, Individual Water Systems, requires that an effective geologic seal exist between the ground surface and the water bearing aquifer and that the annular space between the drilled hole and the well casing be grouted at least $100 \mathrm{ft}(30 \mathrm{~m})$ below surface, or into an effective geologic seal. The regulations also require that water supply wells be isolated from concentrated sources of pollution for a distance of at least $100 \mathrm{ft}(30 \mathrm{~m})$. The county health department approves of water use from the shallow aquifer wells (aquifer above the confined aquifer) based on whether or not samples are potable (Minor, 1995).

The permits ensure that wells are constructed properly and that the quantity of water withdrawn is acceptable. The state engineer's office also has the authority to order repairs, capping, or plugging for any well to prevent ground water pollution or contamination. This office also has the authority to bring suit to prevent ground water pollution.

The state of Utah established a precedent when it restricted withdrawal of ground water. The state engineers' office has developed a Salt Lake Valley Ground Water Management Plan that uses the state engineer's authority to restrict new withdrawals of ground water to protect ground water quality.

Surface water in the state of Utah is classified by permissible uses (for example, drinking, swimming, or boating). If a permitted point source threatens the classification of a surface water body, a National Pollutant Discharge Elimination System permit would be enforced, the discharge would be cleaned up, and the classification would be maintained. If adequate information on a surface water body is not available when a classification is assigned, or if new information becomes available, the Water Quality Board may reclassify a surface water body. However, classification is considered a permanent (not temporary) water quality assessment. Ideally, ground water classification is upgraded over time, rather than downgraded due to degradation from human activities and pollution (Wham, 1994).

\section{Salt Lake City/Salt Lake County}

South Salt Lake City's environmental and health programs are administered through combined city and county agencies. The Bureau of Water Quality and Hazardous Waste for Salt Lake City and Salt Lake County has the authority to assist the state departments of environmental quality and health in notifying residents about health hazards. In the past, residents were notified through posted health warnings, press conferences, and press releases (Minor, 1994; Wham, 1994). 


\subsection{RESULTS OF THE DECEMBER 1994 SAMPLING ROUND}

After this risk assessment was prepared, validated data were obtained from the December 1994 sampling round. Samples of ground water were analyzed as part of the routine ground water monitoring of the site. Surface water and sediment samples were collected and analyzed in response to data gaps identified during the preparation of this risk assessment. This section briefly discusses the results of that sampling event; however, in many cases, these are the first samples taken for specific locations and media. As such, additional sampling will be required in some cases to confirm the findings.

\section{Ground Water}

December 1994 ground water sampling results (Table 8.2) were generally within the range of previous analytical results, although previously observed maximum values for iron, potassium, and molybdenum were exceeded by about a factor of 2 or less. The higher levels of iron $(13.9 \mathrm{mg} / \mathrm{L}$ versus a previous maximum of 6.5 $\mathrm{mg} / \mathrm{L}$ ) and potassium ( $308 \mathrm{mg} / \mathrm{L}$ versus a previous maximum of $228 \mathrm{mg} / \mathrm{L}$ ) are still below thresholds for toxicity in humans and livestock and therefore not a toxicological issue (DOE, 1995a). The higher molybdenum concentration in a filtered sample from well $131(1.4 \mathrm{mg} / \mathrm{L}$ versus a previous maximum of $0.94 \mathrm{mg} / \mathrm{L})$ is still in the range of mild toxicity to humans, as discussed in Section 6.1. The higher molybdenum value does not change the assessment of ecological risks from ground water discussed in Sections 7.3.2 through 7.4.

Vanadium, not previously identified as a contaminant of concern, was detected in ground water during the December 1994 sampling. The results indicate that this constituent needs to be monitored for in plume wells as well as in background to verify these data and to determine their relation, if any, to the site.

Analyses of arsenic in an upgradient monitoring well (006) further demonstrate the presence of arsenic as both dissolved and suspended forms in background ground water near the site. In addition, the occurrence of copper, iron, and lead as suspended particulates in unfiltered samples from this well indicates that these constituents are present in background.

\section{Surface water results}

A second screen sampling of surface water in Mill Creek at locations upstream and downstream of the site confirmed previous results, including uranium at higher levels downstream than upstream of the site (Table 8.3). In addition, the new data indicate higher levels of arsenic, molybdenum, and silver at the downstream location. These data indicate the need for further sampling to determine whether these increases are site related, related to discharge of treated sewage from the CVWRF, or whether they come from some other source. 
Table 8.2 Summary of December 1994 ground water quality data, filtered samples (unless otherwise specified), unconfined aquifer, Salt Lake City, Utah, site ${ }^{a}$

\begin{tabular}{|c|c|c|c|c|c|c|c|c|}
\hline \multirow[b]{3}{*}{ Parameter } & \multicolumn{8}{|c|}{ Monitor well location } \\
\hline & \multicolumn{2}{|c|}{0006} & \multicolumn{2}{|c|}{0007} & \multicolumn{2}{|c|}{0008} & \multicolumn{2}{|c|}{0130} \\
\hline & $\mathbf{F}$ & $\mathbf{u}$ & $\mathbf{F}$ & $\mathbf{U}$ & $\mathbf{F}$ & $\mathbf{u}$ & $\bar{F}$ & $\bar{U}$ \\
\hline Aluminum & $<0.05$ & 25.0 & $<0.05$ & 0.24 & $<0.05$ & 3.88 & $<0.05$ & $<0.05$ \\
\hline Ammonium ${ }^{b}$ & NA & 55.6 & NA & 9.58 & NA & 11.0 & NA & 18.0 \\
\hline Arsenic & 0.080 & 0.150 & 0.034 & 0.03 & 0.017 & 0.016 & 0.085 & 0.077 \\
\hline Barium $^{b}$ & 0.15 & 0.57 & 0.12 & 0.13 & 0.23 & 0.41 & 0.35 & 0.34 \\
\hline Calciumb & 75.9 & NA & 12.6 & NA & 91.8 & NA & 52.9 & NA \\
\hline Chloride $^{b}$ & NA & 342 & NA & 69.0 & NA & 925 & NA & 296 \\
\hline Copper & $<0.02$ & 0.22 & $<0.02$ & $<0.02$ & $<0.02$ & 0.03 & $<0.02$ & $<0.02$ \\
\hline Fluoride $^{b}$ & NA & 0.38 & NA & 0.71 & NA & 0.55 & NA & 0.63 \\
\hline Iron $^{b}$ & 0.21 & 47.5 & 0.06 & 0.90 & 0.90 & 13.9 & 2.27 & 2.26 \\
\hline Lead & $<0.003$ & 0.550 & $<0.003$ & 0.003 & $<0.003$ & $<0.003$ & $<0.003$ & $<0.003$ \\
\hline Magnesium $^{b}$ & 68.0 & NA & 37.0 & NA & $151^{\circ}$ & NA & 101 & NA \\
\hline Manganese ${ }^{b}$ & 0.53 & NA & 0.03 & NA & 0.11 & NA & 0.20 & NA \\
\hline Molybdenumb & $<0.01$ & NA & $<0.01$ & NA & $<0.01$ & NA & 0.19 & NA \\
\hline Potassium ${ }^{b}$ & 58.5 & NA & 35.2 & NA & 52.5 & NA & 67.6 & NA \\
\hline Radium-226 $6^{\mathrm{b}, \mathrm{c}}$ & 0.3 & NA & 0.3 & NA & 1.0 & NA & 0.7 & NA \\
\hline Silver ${ }^{b}$ & $<0.0002$ & NA & $<0.0002$ & NA & $<0.0002$ & NA & $<0.0002$ & NA \\
\hline Sodium ${ }^{b}$ & 230 & NA & 130 & NA & 380 & NA & 270 & NA \\
\hline Strontium ${ }^{b}$ & 0.80 & NA & 0.22 & NA & 1.42 & NA & 0.57 & NA \\
\hline Sulfate $^{b}$ & NA & 56 & NA & 4.7 & NA & 2020 & NA & 214 \\
\hline TDS & 1220 & & 565 & & 5350 & & 1470 & \\
\hline Uranium $^{b}$ & 0.003 & NA & $<0.001$ & NA & 0.005 & NA & 0.002 & NA \\
\hline Vanadium & ND & & ND & & ND & & ND & \\
\hline
\end{tabular}




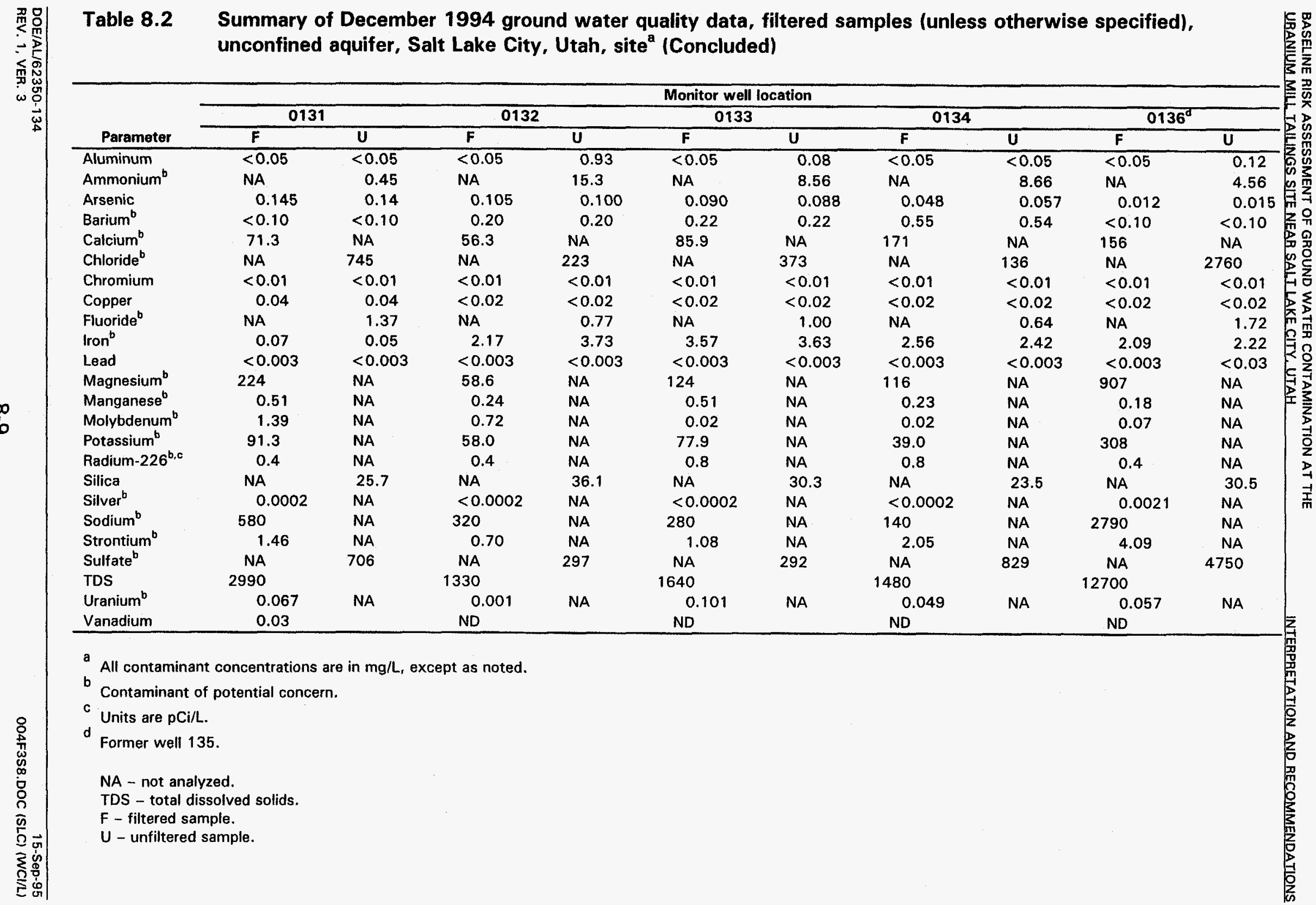


Table 8.3 Summary of Mill Creek surface water quality data, December 1994, Salt Lake City, Utah, site

\begin{tabular}{|c|c|c|c|c|}
\hline \multirow[b]{2}{*}{ Parameter } & \multicolumn{2}{|c|}{ Upstream location 180} & \multicolumn{2}{|c|}{ Downstream Location 182} \\
\hline & Filtered & Unfiltered & Filtered & Unfiltered \\
\hline \multicolumn{5}{|l|}{ Inorganic constituents } \\
\hline Alkalinity as $\mathrm{CaCO}_{3}$ & NA & 225 & NA & 244 \\
\hline Aluminum & 0.05 & 0.13 & $<0.05$ & $<0.05$ \\
\hline Ammonium & NA & 0.26 & NA & 0.79 \\
\hline Arsenic & $<0.005$ & $<0.005$ & 0.006 & 0.006 \\
\hline Barium & $<0.10$ & $<0.10$ & $<0.10$ & $<0.10$ \\
\hline Calcium & 116 & NA & 93 & NA \\
\hline Chloride & NA & 122 & NA & 279 \\
\hline Chromium & $<0.01$ & $<0.01$ & $<0.01$ & $<0.01$ \\
\hline Copper & $<0.02$ & $<0.02$ & $<0.02$ & 0.02 \\
\hline Fluoride & NA & 0.22 & NA & 0.63 \\
\hline Iron & $<0.03$ & 0.26 & 0.04 & 0.10 \\
\hline Lead & $<0.003$ & $<0.003$ & $<0.003$ & $<0.02$ \\
\hline Magnesium & 39 & NA & 42 & NA \\
\hline Manganese & 0.02 & 0.02 & 0.03 & 0.03 \\
\hline Molybdenum & $<0.01$ & $<0.01$ & 0.01 & 0.02 \\
\hline $\mathrm{pH}$ & NA & 7.94 & NA & 6.92 \\
\hline Potassium & 4.0 & NA & 20.7 & NA \\
\hline Silica & 21 & 20 & 23 & 22 \\
\hline Silver & $<0.0002$ & $<0.0002$ & 0.0002 & 0.0005 \\
\hline Sodium & 71 & NA & 180 & NA \\
\hline Strontium & 1.1 & 1.1 & 0.94 & 0.92 \\
\hline Sulfate & NA & 138 & NA & 133 \\
\hline Total dissolved solids & 729 & NA & 960 & NA \\
\hline Uranium & 0.001 & 0.002 & 0.007 & 0.007 \\
\hline Vanadium & $<0.01$ & $<0.01$ & $<0.01$ & $<0.01$ \\
\hline \multicolumn{5}{|l|}{ Radionuclide } \\
\hline Radium-226 & 0.1 & 0.1 & 0.0 & 0.1 \\
\hline
\end{tabular}

Notes: 1. Inorganic constituent concentrations in milligrams per liter, except for $\mathrm{pH}$ (standard units). Radionuclide radium-226 in picocuries per liter.

2 . $<$ indicates less than the given method detection limit.

NA - not analyzed. 
Surface water in South Vitro Ditch and Vitro Ditch was sampled for the first time in December 1994. The results indicate the presence above the detection limit of dissolved species of uranium and molybdenum (Table 8.4). These constituents are known to be present in contaminated ground water at the site, and their occurrence suggests that these surface water bodies are receiving contaminated ground water. In addition, dissolved vanadium is present in South Vitro Ditch.

A first-time screening of Vitro Ditch in the marshy area east of the site indicates the presence of arsenic, barium, copper, iron, lead, and silver as suspended particulates in surface water at that location. These constituents were also found in surface water at the confluence of Vitro and South Vitro Ditches (location 187, Table 8.4). It is reasonable to suggest that these constituents are not site-related considering that these elements occur naturally in copper deposits within the drainage basin of the Salt Lake Valley and that several of these constituents are also found (as suspended particulates) in shallow ground water from upgradient monitoring well 006.

\subsection{RECOMMENDATIONS}

The shallow ground water under the site is not considered potable. Current restrictions on using ground water from the shallow aquifer for drinking should be maintained until the water quality improves.

Monitoring water levels of both the unconfined and the confined aquifers is recommended. It is not possible at this time to model and evaluate the potential drawdown effects to the confined aquifer due to pumping of the proposed municipal well. Therefore, if the municipal well is to be used, the drawdown effects should be evaluated at that time.

The off-site extent and depth of ground water contamination in the unconfined aquifer should be identified during future characterization and remedial planning activities by installing monitor wells downgradient (to the west, northwest, and north). Better characterization of background ground water and surface water quality and surface water and sediment contamination may also be part of this future field work. One possible focus of this effort is the molybdenum in South Vitro Ditch sediments and possibly in nearby vegetation. Ground water monitoring in the unconfined aquifer should continue. Future field plans will describe the sampling locations, analytes, and frequencies. 
Table 8.4 Summary of Vitro Ditch and South Vitro Ditch surface water quality data, December 1994, Salt Lake City, Utah, site

\begin{tabular}{|c|c|c|c|c|c|c|}
\hline \multirow[b]{3}{*}{ Parameter } & \multicolumn{4}{|c|}{ South Vitro Ditch (on site) } & \multicolumn{2}{|c|}{ Vitro Ditch (east of site) } \\
\hline & \multicolumn{2}{|c|}{$\begin{array}{c}\text { South end } \\
\text { Location } 186\end{array}$} & \multicolumn{2}{|c|}{$\begin{array}{l}\text { North end at confluence } \\
\text { with Vitro Ditch } \\
\text { Location } 187\end{array}$} & \multicolumn{2}{|c|}{ Location 191} \\
\hline & Filtered & Unfiltered & Filtered & Unfiltered & Filtered & Unfiltered \\
\hline \multicolumn{7}{|c|}{ Inorganic Constituents } \\
\hline $\begin{array}{l}\text { Alkalinity as } \\
\mathrm{CaCO}_{3}\end{array}$ & NA & 296 & NA & 267 & NA & 85 \\
\hline Aluminum & $<0.05$ & 0.12 & $<0.05$ & 0.71 & $<0.05$ & 1.68 \\
\hline Ammonium & NA & 0.61 & NA & 0.63 & NA & 0.31 \\
\hline Arsenic & 0.026 & 0.028 & 0.017 & 0.022 & $<0.005$ & 0.008 \\
\hline Barium & $<0.10$ & $<0.10$ & $<0.10$ & 0.10 & 0.10 & 0.11 \\
\hline Calcium & 79 & NA & 93 & NA & 76 & NA \\
\hline Chloride & NA & 240 & NA & 324 & NA & 769 \\
\hline Chromium & $<0.01$ & $<0.01$ & $<0.01$ & $<0.01$ & $<0.01$ & $<0.01$ \\
\hline Copper & $<0.02$ & $<0.02$ & $<0.02$ & 0.03 & $<0.02$ & 0.03 \\
\hline Fluoride & NA & 0.68 & NA & 0.66 & NA & 0.35 \\
\hline Iron & $<0.03$ & 0.21 & $<0.03$ & 1.18 & 0.12 & 2.11 \\
\hline Lead & $<0.003$ & $<0.003$ & $<0.003$ & 0.014 & $<0.003$ & 0.021 \\
\hline Magnesium & 56 & NA & 63 & NA & 34 & NA \\
\hline Manganese & 0.04 & 0.04 & 0.06 & 0.08 & 0.15 & 0.16 \\
\hline Molybdenum & 0.12 & 0.12 & 0.14 & 0.13 & 0.01 & 0.01 \\
\hline $\mathrm{pH}$ & NA & 7.53 & NA & 7.55 & NA & 7.43 \\
\hline Potassium & 22.4 & NA & 24.7 & NA & 10.6 & NA \\
\hline Silica & 21 & 22 & 23 & 24 & 7 & 17 \\
\hline Silver & $<0.0002$ & $<0.0002$ & $<0.0002$ & 0.0003 & 0.0002 & 0.0004 \\
\hline Sodium & 200 & NA & 250 & NA & 510 & NA \\
\hline Strontium & 0.87 & 0.84 & 0.90 & 0.88 & 0.61 & 0.61 \\
\hline Sulfate & NA & 179 & NA & 242 & NA & 138 \\
\hline $\begin{array}{l}\text { Total dissolved } \\
\text { solids }\end{array}$ & 1040 & NA & 1220 & NA & 1710 & NA \\
\hline Uranium & 0.024 & 0.023 & 0.037 & 0.028 & 0.008 & 0.008 \\
\hline Vanadium & 0.04 & 0.04 & 0.03 & 0.03 & $<0.01$ & $<0.01$ \\
\hline \multicolumn{7}{|l|}{ Radionuclide } \\
\hline Radium-226 & 0.3 & 0.3 & 0.3 & 0.3 & 0.1 & 0.2 \\
\hline
\end{tabular}

Notes: 1. Inorganic constituent concentrations in milligrams per liter, except for $\mathrm{pH}$ (standard units). Radionuclide radium-226 in picocuries per liter.

2. NA - not analyzed.

3. < indicates less than the given method detection limit. 


\subsection{LIST OF CONTRIBUTORS}

\begin{tabular}{ll}
\hline Name & Contribution \\
\hline B. Malczewska-Toth & Overall document responsibility; author \\
L. Flowers & Senior technical reviewer \\
C. Burt & Environmental evaluation \\
K. Smith, J. Weidner & Statistics \\
E. Storms & Hydrogeology \\
T. Jackson & Geochemistry \\
M. Gawthrop-Cooper & Risk mitigation measures \\
S. Cox, S. Wright & Site manager \\
WordCenter, Inc. & Word processing \\
E. Bond & Graphic design \\
D. Tamez & Technical editing \\
V. Beck, J. Torline & Technical editing, document production \\
\hline
\end{tabular}




\subsection{REFERENCES}

AHFS (American Hospital Formulary Service), 1991. American Society of Hospital Pharmacy, Gerald McEvoy, ed., Bethesda, Maryland, pp. 1506, 1706.

Aikawa, J. K., 1963. The Role of Magnesium in Biologic Processes, C. C. Thomas, publisher, Springfield, Illinois.

Alexander et al. (F. W. Alexander, B. E. Clayton, and H. T. Delves), 1974. O.J. Med., Vol. 53, pp. 89-111.

Anderson et al. (J. E. Anderson, M. L. Shumar, N. L. Toft, and R. S. Nowak), 1987. "Control of the Soil Water Balance by Sagebrush and Three Perennial Grasses in a Cold-Desert Environment," in Arid Soil and Rehabilitation, Vol. 1, pp. 229-224.

Arnow et al. (T. Arnow, R. Van Horn, and R. La Pray), 1970. "The Pre-Quaternary Surface in the Jordan Valley," in Geological Survey Research 1970, U.S. Geological Survey Professional Paper 700-D, Washington, D.C., pp. D257-D261.

Ballou et al. (J. E. Ballou, R. A. Gies, A. C. Case, D. L. Haggard, R. L. Buschbom, and J. L. Ryan), 1986. "Deposition and Early Disposition of Inhaled Uranium-233 Uranyl Nitrate and Uranium-232 Uranyl Nitrate in the Rat," in Health Physics, No. 51, pp. 755-772.

Berlin, M., and B. Rudell, 1986. "Uranium," Handbook on the Toxicology of Metals, second edition, L. Friberg, G. F. Nordberg, and V. B. Vouk, eds., Elsevier Science Publishers, Amsterdam, pp. 647-658.

Brater, D.C., 1992. "Treatment of Renal Disorders and the Influence of Renal Function on Drug Disposition," in Clinical Pharmacology, Vol. 31, pp. 776-785.

CDH (Colorado Department of Health), 1991. Basic Standards and Methodologies for Surface Water, 3.1.0., Water Quality Control Commission, Denver, Colorado.

Calabrese, E. J., and R. W. Tuthill, 1977. "Elevated Blood Pressure and High Radium Levels in the Public Drinking Water," in Archives of Environmental Health, September/October 1977, pp. 200-202.

Carson et al. (B. L. Carson, H. V. Ellis III, and J. L. McCann), 1986. Toxicology and Biological Monitoring of Metals in Humans, Lewis Publishers, Inc., New York, New York, pp. 226-230.

Casarett, L. J., and J. Doull, 1991. Toxicology: The Basic Science of Poisons, fourth edition, M. O. Amdur, J. Doull, and C. D. Klaassen, eds., Pergamon Press, New York, New York. 
Church, D. C., 1984. Livestock Feeds and Feeding, second edition, McGraw-Hill Publishing Co., New York, New York.

Cothern, C. R., and W. L. Lappenbusch, 1983. "Occurrence of Uranium in Drinking Water in the United States," in Health Physics, No. 45, pp. 89-99.

Davies, E. B., 1956. "Factors Affecting Molybdenum Availability in Soils," in Soil Science, No. 81, pp. 209-221.

DHHS (U.S. Department of Health and Human Services), 1992. "Toxicological Profile for Manganese and Compounds," prepared by Life Systems Inc., for Clement International Corporation for the U.S. Department of Health and Human Services.

DNR (Department of Natural Resources), 1971. Reconnaissance of the Shallow-Unconfined Aquifer In Salt Lake Valley, Utah, Water-Resources Investigations Report 83-4272, prepared by the U.S. Geological Survey in cooperation with the Salt Lake County Water Conservancy District and the Salt Lake County Division of Floord Control and Water Quality.

DOE (U.S. Department of Energy), 1995a. Supplement to the Baseline Risk Assessment of Ground Water Contamination at the Uranium Mill Tailings Site Near Salt Lake City, Utah, DOE/AL/62350-134S, prepared by the U.S. Department of Energy, UMTRA Project Office, Albuquerque Operations Office, Albuquerque, New Mexico.

DOE (U.S. Department of Energy), 1995b. Completion Report for the UMTRA Project Vitro Processing Site, Salt Lake City, Utah, DOE/AL/62350-129, Rev. 1, Ver. 3, prepared by the U.S. Department of Energy, UMTRA Project Office, Albuquerque Operations Office, Albuquerque, New Mexico.

DOE (U.S. Department of Energy), 1994a. Vitro Uranium Mill Tailings Remedial Action Project and Central Valley Vicinity Property Remedial Action Project Completion Report, DOE/AL/62350-129, prepared by the U.S. Department of Energy, UMTRA Project Office, Albuquerque Operations Office, Albuquerque, New Mexico.

DOE (U.S. Department of Energy), 1994b. Programmatic Environmental Impact Statement for the Uranium Mill Tailings Remedial Action Ground Water Project, draft, DOE/EIS-0198, Rev. 3, April 1994, prepared by the U.S. Department of Energy, UMTRA Project Office, Albuquerque Operations Office, Albuquerque, New Mexico.

DOE (U.S. Department of Energy), 1993. Hydrological Characterization of the Former Vitro Processing Site, Salt Lake City, UMTRA - DOE/AL-050130.0000, prepared by the U.S. Department of Energy, UMTRA Project Office, Albuquerque Operations Office, Albuquerque, New Mexico.

DOE (U.S. Department of Energy), 1984a. Remedial Actions at the Former Vitro Chemical Company Site, South Salt Lake, Salt Lake County, Utah, Vol. 1, final, DOE/EIS-0099-F, prepared by the U.S. Department of Energy, UMTRA Project Office, Albuquerque Operations Office, Albuquerque, New Mexico. 
DOE (U.S. Department of Energy), 1984b. Processing Site Characterization Report for the UMTRA Site at Salt Lake City, Utah, Report No. UMTRA-DOE/AL-050102.0000.

DOE (U.S. Department of Energy), 1983. Data for the Geochemical Investigation of UMTRAP Designated Site at Salt Lake City, Utah, UMTRA-DOE/AL-0236, prepared by the U.S. Department of Energy, UMTRA Project Office, Albuquerque Operations Office, Albuquerque, New Mexico.

EPA (U.S. Environmental Protection Agency), 1994a. "Integrated Risk Information System (IRIS)," data base, Office of Research and Development, Washington, D.C.

EPA (U.S. Environmental Protection Agency), 1994b. "Health Effects Assessment Summary Tables (HEAST)," annual update, March 1994, 9200.6-303 (94-1), Office of Solid Waste and Emergency Response, Washington, D.C.

EPA (U.S. Environmental Protection Agency), 1993. Drinking Water Regulations and Health Advisories, prepared by the U.S. Environmental Protection Agency, Office of Water, Washington, D.C.

EPA (U.S. Environmental Protection Agency), 1992a. Drinking Water Criteria Document for Sulfate, final, Health and Environmental Criteria Division, Office of Science and Technology, U.S. Environmental Protection Agency.

EPA (U.S. Environmental Protection Agency), 1992b. Eco Update, Publication 9345.0-051, U.S. Environmental Protection Agency, Office of Solid Waste and Emergency Response, Washington, D.C.

EPA (U.S. Environmental Protection Agency), 1991. 304(a) Criteria and Related Information for Toxic Pollutants, EPA Region IV, Water Management Division.

EPA (U.S. Environmental Protection Agency), 1989a. Risk Assessment Guidance for Superfund, Vol. I, Human Health Evaluation Manual, Part A, interim final, EPA/540/1-89/002, Office of Solid Waste, Waste Management Division, Washington, D.C.

EPA (U.S. Environmental Protection Agency), 1989b. Risk Assessment Guidance for Superfund, Vol. II, Environmental Evaluation Manual, EPA/504/1-89/001, U.S. Environmental Protection Agency, Office of Emergency and Remedial Response, Washington, D.C.

EPA (U.S. Environmental Protection Agency), 1987. Ambient Aquatic Life Water Quality Criteria for Silver, U.S. Environmental Protection Agency, Office of Research and Development, Duluth, Minnesota.

EPA (U.S. Environmental Protection Agencyl, 1986. Quality Criteria for Water, 1986, U.S. Environmental Protection Agency, Office of Water, Regulations, and Standards, Washington, D.C. 
EPA (U.S. Environmental Protection Agency), 1973. Water Quality Criteria, National Academy of Sciences and National Academy of Engineering, Washington, D.C.

Eisler, R., 1989. Molybdenum Hazards to Fish, Wildlife, and Invertebrates: A Synoptic Review, U.S. Fish and Wildlife Service, Biological Report 85(1.19), Patuxent Wildlife Research Center, Laurel, Maryland.

Elinder, C. G., 1986. "Iron," Handbook on the Toxicology of Metals, second edition, L. Friberg, G. F. Nordberg, and V. Houk, eds., Elsevier Science Publishers, Amsterdam.

Erdman et al. (J. A. Erdman, R. J. Ebens, and A. A. Case), 1978. "Molybdenosis: A Potential Problem in Ruminants Grazing on Coal Mine Spoils," in Journal of Range Management, Vol. 31, No. 1, pp. 34-36.

Filbert, R., and P. Holden, 1992. Fishery Investigations of the Lower Jordan River, Utah, Final Report 1988-1991, BIO/WEST, Inc., Logan, Utah.

Fisenne et al. (I. M. Fisenne, P. M. Perry, and N. H. Harley, 1988. "Uranium in Humans," in Radiation Protection Dosimetry, No. 24, pp. 127-131.

Freis, E. D., 1976. "Salt, Volume and the Prevention of Hypertension," in Circulation, Vol. 53, No. 4, pp. 589-595.

Friberg et al. (L. Friberg, G. F. Nordberg, and V. B. Vouk), 1986. Handbook on the Toxicology of Metals, Volume II: Specific Metals, second edition, Elsevier Science Publishers, New York, New York.

Gilman et al. (A. G. Gilman, L. S. Goodman, and A. Gilman), 1990. The Pharmacological Basis of Therapeutics, sixth edition, Macmillan Publishing Company, Inc., New York, New York.

Goyer, Robert A., 1991. "Toxic Effects of Metals," in Toxicology: The Basic Science of Poisons, fourth edition, M. O. Amdur, J. Doull, and C. D. Klaassen, eds., Pergamon Press, New York, New York, pp. 623-680.

Hely et al. (A. G. Hely, R. W. Mower, and C. A. Harr), 1971. Water Resources of the Salt Lake County, Utah, State of Utah Department of Natural Resources, Technical Publication No. 31, Salt Lake City, Utah.

Israeli, M., and C. B. Nelson, 1992. "Distribution and Expected Time of Residence for U.S. Households," in Risk Analysis, Vol. 13, No. 1, pp. 65-72.

JEG (Jacobs Engineering Group, Inc.), 1986. Suggested Heavy Metal Concentration Limits for Soil at UMTRA Project Sites, prepared by JEG for the U.S. Department of Energy, UMTRA Project Office, Albuquerque Operations Office, Albuquerque, New Mexico. 
Jarrell et al. (W. M. Jarrell, A. L. Page, and A. A. Elseewi), 1980. "Molybdenum in the Environment," in Residue Reviews, Vol. 74, pp. 1-35.

Kabata-Pendias, A., and H. Pendias, 1992. Trace Elements in Soils and Plants, second edition, CRC Press, Boca Raton, Florida.

Kondakis et al. (X. G. Kondakis, N. Makris, M. Leotsinidis, M. Prinou, and T.

Papapetropoulos), 1989. "Possible Health Effects of High Manganese Concentration in Drinking Water," in Archives of Environmental Health, Vol. 44, No. 3, pp. 175178.

Kubota et al. (J. Kubota, V. A. Lazab, L. N. Langan, and K. C. Beeron), 1961. The Relationship of Molybdenum Toxicity in Cattle in Nevada, U.S. Plant Nutrition Laboratory, Ithaca, New York.

Leach et al. (L. J. Leach, R. M. Gelein, B. J. Panner, C. L. Ylie, and C. C. Coxl, 1984. The Acute Toxicity of the Hydrolysis Products of Uranium Hexafluoride (UF6) When Inhaled by the Rat and Guinea Pig, final report, ISS K/SUB-81-9039-3, National Technical Information Service, DE84011539.

Long, E. R., and L. G. Morgan, 1990. "The Potential for Biological Effects of SedimentSorbed Contaminants Tested in the National Status and Trends Program," National Oceanic and Atmospheric Administration, Technical Memorandum NOS OMA 52, Seattle, Washington.

Lönnerdal et al. (B. Lönnerdal, C. L. Keen, J. G. Bell, and B. Sandstrom), 1987. "Manganese Uptake and Retention," Nutritional Bioavailability of Manganese, C. Kies, ed., American Chemical Society, symposium series 354, pp. 9-20, American Chemical Society, Washington, D.C.

Maheshwari et al. (U. R. Maheshwari, J. T. McDonald, V. S. Schneider, A. J. Brunetti, L. L. Leybin, E. Newbrun, and H. C. Hodgel, 1981. "Fluoride Balance Studies in Ambulatory Healthy Men With and Without Fluoride Supplements," in American Journal of Clinical Nutrition, December 1981, Vol. 34, pp. 2679-2684.

Markos, G., and K. J. Bush, 1982. Geochemical Investigation of UMTRAP Designated Site at Salt Lake City, Utah, GECR \#R-826, Contract \#DE-AC04-82AL18797, Document DOE/UMT/0235, prepared by GECR, Inc., Rapid City, South Dakota, prepared for the U.S. Department of Energy, UMTRA Project Office, Albuquerque Operations Office, Albuquerque, New Mexico.

Mattick, R. E., 1970. "Thickness of Unconsolidated to Semiconsolidated Sediments in Jordan Valley, Utah," Geological Survey Research 1970, U.S. Geological Survey Professional Paper 700-C, Washington, D.C. 
Maynard, E. A., and H. C. Hodge, 1949. "Study of Toxicity of Various Uranium Compounds When Fed to Experimental Animals," Pharmacology and Toxicology of Uranium Compounds, C. Voegtlin and H. C. Hodge, eds., National Nuclear Energy Services, Div. VI, McGraw Hill, New York, New York, Vol. 1, pp. 309-376.

Mena et al. (I. Mena, K. Horiuchi, K. Burke, and G. C. Cotzias), 1969. "Chronic Manganese Poisoning, Individual Susceptibility and Absorption of Iron," in Neurology, No. 19, pp. 1000-1006.

Meneely, G. R., and H. D. Battarbee, 1976. "Sodium and Potassium," in Nutrition Reviews, No. 8, pp. 225-235.

Merritt, R. C., 1971. The Extractive Metallurgy of Uranium, Colorado School of Mines Research Institute, Golden, Colorado, 1971.

Minor, G., 1994. Bureau of Water Quality and Hazardous Waste, Salt Lake City/County, Salt Lake City, Utah, personal communication to Malu Gawthrop-Cooper, Jacobs Engineering Group Inc., UPDCC File Location No. 2.19.7, Albuquerque, New Mexico, June 1, 1994.

NCRP (National Council on Radiation Protection and Measurements), 1984. Exposure from the Uranium Series With Emphasis on Radon and Its Daughters, NCRP Report No. 77. Bethesda, Maryland.

NRC (U.S. Nuclear Regulatory Commission), 1977. Calculations of Annual Doses to Man From Routine Releases of Reactor Effluents for the Purpose of Evaluating Compliance With 10 CFR Part 50, Appendix 1, Regulatory Guide 1.109, U.S. Nuclear Regulatory Commission, Washington, D.C.

National Research Council, 1989. Recommended Daily Allowances, tenth edition, Commission on Life Sciences, National Academy Press, Washington, D.C.

National Research Council, 1980. Drinking Water and Health, Vol. 3, Safe Drinking Water Committee, National Academy Press, Washington, D.C.

National Research Council, 1973. Medical and Biological Effects of Environmental Pollutants: Manganese, Committee on Biologic Effects of Atmospheric Pollutants, Division of Medical Sciences, Washington, D.C.

Palisade Corporation, 1992. @RISK, Risk Analysis and Simulation Add-In for Lotus 1-2-3, Version 2.01, Newfield, New York.

Parkhurst et al. (D. L. Parkhurst, D. C. Thorstenson, and D. N. Plummer), 1980. PHREEQE $3 / 4$ A Computer Program for Geochemical Calculations, U.S. Geological Survey, Water Resources Investigation 80-96, National Technical Information Services Report PB81-167-801, Springfield, Virginia. 
Persaud et al. (D. Persaud, R. Jaagumagi, and A. Hayton), 1990. The Provincial Sediment Quality Guidelines, Ontario Ministry of the Environment, Water Resources Branch, Toronto, Ontario.

Prister, B. S., 1969. GKIAE Report by Atomizdat, Moscow (Canadian translation AEC/TR/7178 (1970), and USCEAR Rep. A/AC.82/G/L 1298).

Reynolds, T. D., 1990. "Root Mass and Vertical Root Distribution of Five Semi-Arid Plant Species," in Health Physics, Vol. 58, No. 2, pp. 191-197.

Robinson et al. (M. F. Robinson, J. M. McKenzie, C. Thomson, and A. L. Van Rijn), 1973. in Br. J. Nutr., Vol. 30, pp. 195-205.

Roseberry, A. M., and D. E. Burmaster, 1992. "Lognormal Distributions for Water Intake by Children and Adults," in Risk Analysis, Vol. 12, No. 1, pp. 99-104.

Rosoff, B., and H. Spencer, 1964. Nature (London), Vol. 202, pp. 410-411.

Saric, M., 1986. "Manganese," Handbook on the Toxicology of Metals, Volume II, L. Friberg, G. F. Nordberg, V. B. Vouk, eds., Elsevier, New York, pp. 354-386.

Seiler, R. L., and K. M. Waddell, 1983. "Reconnaissance of the Shallow-Unconfined Aquifer in Salt Lake Valley, Utah," Water Resources Investigations Report 83-4272, U.S. Geological Survey in cooperation with Salt Lake County, Salt Lake City, Utah.

Shleien, B., 1992. The Health Physics and Radiological Health Handbook, Scinta, Inc., Silver Spring, MD.

Stevens et al. (W. F. Stevens, W. Bruenger, D. R. Atherton, J. M. Smith, and G. N. Taylor), 1980. "The Distribution and Retention of Hexavalent ${ }^{233} \mathrm{U}$ in the Beagle," in Radiation Research, No. 83, pp. 109-126.

Sullivan et al. (M. F. Sullivan, P. S. Ruemmler, J. L. Ryan, and R. L. Bushhom), 1986. "Influence of Oxidizing or Reducing Agents on Gastrointestinal Absorption of $\mathrm{U}, \mathrm{Pu}$, Am, Cm, and Pm by Rats," in Health Physics, No. 50, pp. 223-232.

TAC (Technical Assistance Contractor), 1994. Summary of Field Activities at Salt Lake City, May 3-5, 1994, compiled by the Technical Assistance Contractor, Jacobs Engineering Group Inc., for the U.S. Department of Energy, UPDCC File Location No. 2.19.7, UMTRA Project Office, Albuquerque Operations Office, Albuquerque, New Mexico, May 13, 1994.

TAC (Technical Assistance Contractor), 1993. "Unpublished Field Notes, Salt Lake City, Utah, Uranium Mill Tailings Site," unpublished report prepared by the Technical Assistance Contractor, Albuquerque, New Mexico, for the U.S. Department of Energy, UMTRA Project Office, Albuquerque Operations Office, Albuquerque, New Mexico. 
TAC (Technical Assistance Contractor), 1992. Salt Lake City Site Average Linear Ground Water Velocity Calculation, SLC-07-92-14-03-00, August 6, 1992, prepared by the Technical Assistance Contractor, Jacobs Engineering Group Inc., for the U.S. Department of Energy, UPDCC File Location No. 2.19.2.7, UMTRA Project Office, Albuquerque Operations Office, Albuquerque, New Mexico.

Tipton et al. (I. H. Tipton, P. L. Stewart, and J. Dickson), 1969. Hea/th Phys., Vol. 9, pp. 103-145.

Tracy et al. (B. L. Tracy, J. M. Quinn, J. Lahey, A. P. Gilman, K. Mancuso, A. P. Yagdinas, and D. C. Villeneuve), 1992. "Absorption and Retention of Uranium from Drinking Water by Rats and Rabbits," in Health Physics, Vol. 62, pp. 65-73.

Tracy et al. (B. L. Tracy, F. A. Prantl, and J. M. Quinn), 1983. "Transfer of ${ }^{226} \mathrm{Ra},{ }^{210} \mathrm{~Pb}$, and Uranium from Soil to Garden Produce: Assessment of Risk," in Health Physics, Vol. 44 , p. 469.

UDEQ (Utah Department of Environmental Quality), 1992. Standards of Quality for Waters of the State, Utah Department of Environmental Quality, Division of Water Quality, Salt Lake City, Utah.

USGS (U.S. Geological Survey), 1984. Summary of Water Resources of Salt Lake County, Utah, Technical Publication No. 34, prepared by the U.S. Geological Survey in cooperation with the Utah Department of Natural Resources, Division of Water Rights.

Venugopal, B., and T. D. Luckey, 1978. "Chemical Toxicity of Metals and Metalloids," Metal Toxicity in Mammals, Plenum Press, New York, New York.

Weigel, F., 1983. "Uranium and Uranium Compounds," Kirk-Othmer Encyclopedia of Chemical Technology, third edition, M. Grayson, ed., John Wiley and Sons, New York, New York, Vol. 23, pp. 502-547.

Wham, D., 1994. Department of Environmental Quality, Division of Water Quality Surface Water, Salt Lake City, Utah, personal communication to Malu GawthropCooper, Jacobs Engineering Group Inc., UPDCC File Location No. 2.19.7, Albuquerque, New Mexico, June 1, 1994.

Wrenn et al. (M. E. Wrenn, P. W. Durbin, B. Howard, J. Lipsztein, J. Rundo, E. T. Still, and D. L. Willis), 1985. "Metabolism of Ingested $U$ and Ra," in Health Physics, No. 48, pp. 601-633.

\section{CODE OF FEDERAL REGULATIONS}

40 CFR Part 264, Standards for Owners and Operators of Hazardous Waste Treatment, Storage, and Disposal Facilities, U.S. Environmental Protection Agency (1994). 
FEDERAL REGISTER

60 FR 2854, Ground Water Standards for Remedial Actions at Inactive Uranium Processing Sites; Final Rule, U.S. Environmental Protection Agency, 11 January 1995.

\section{UNITED STATES CODES}

42 USC $\$ 7901$ et seq., Uranium Mill Tailings Radiation Control Act, November 8, 1978. 